\title{
NOG STEEDS EEN MIRAKEL? DE LEGITIMITEIT VAN HET POLDERMODEL IN DE EENENTWINTIGSTE EEUW
}

ONDER REDACTIE VAN MAARTEN KEUNE 
Nog steeds een mirakel? De legitimiteit van het poldermodel in de eenentwintigste eeuw 



\section{Nog steeds een mirakel? \\ De legitimiteit van het poldermodel in de eenentwintigste eeuw}

Onder redactie van

Maarten Keune 
Ontwerp binnenwerk: Crius Group, Hulshout

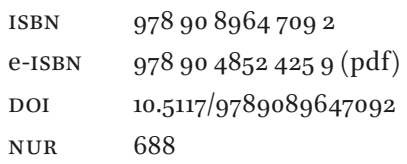

\section{(c) $(1) \Theta$}

Creative Commons License CC BY NC ND (http://creativecommons.org/licenses/by-nc/3.o)

@ Maarten Keune / Amsterdam University Press B.V., Amsterdam 2016

Alle rechten voorbehouden. Niets uit deze uitgave mag worden verveelvoudigd, opgeslagen in een geautomatiseerd gegevensbestand, of openbaar gemaakt, in enige vorm of op enige wijze, hetzij elektronisch, mechanisch, door fotokopieën, opnamen of enige andere manier, zonder voorafgaande schriftelijke toestemming van de uitgever.

Voor zover het maken van kopieën uit deze uitgave is toegestaan op grond van artikel 16B Auteurswet $1912 \mathrm{j}^{\circ}$ het Besluit van 20 juni 1974, Stb. 351, zoals gewijzigd bij het Besluit van 23 augustus 1985, Stb. 471 en artikel 17 Auteurswet 1912, dient men de daarvoor wettelijk verschuldigde vergoedingen te voldoen aan de Stichting Reprorecht (Postbus 3051, 2130 KB Hoofddorp). Voor het overnemen van gedeelte(n) uit deze uitgave in bloemlezingen, readers en andere compilatiewerken (artikel 16 Auteurswet 1912) dient men zich tot de uitgever te wenden. 


\section{Inhoud}

Voorwoord

Maarten Keune

$1 \quad$ Inleiding

De legitimiteit van het poldermodel in de eenentwintigste eeuw Maarten Keune

2 Het Nederlandse poldermodel langs de democratische meetlat Over representativiteit, verantwoording en belangenvertegenwoordiging Caelesta Braun

3 Past de overlegeconomie nog in de wereld van globalisering en Europese integratie? Jelle Visser

4 Afbrokkelende legitimiteit van het poldermodel Paul de Beer

5 De keerzijde van het polderwonder

Ewald Engelen

6 Het pensioenmirakel ontleed

Functionaliteit en legitimiteit in het Nederlandse pensioenstelsel Natascha van der Zwan

7 Nieuw Nederlands polderen

Van brede sociale akkoorden naar 'ad hoc' hervormingscoalities

Anton Hemerijck en Marc van der Meer

8 De invloed van het sociaal akkoord op de Nederlandse arbeidswetgeving

Klara Boonstra

9 In de schaduw van de markt?

Een reflectie op de robuustheid van looncoördinatie via doorwerking

Arjen Verhoeff 
Auteurs

Bibliografie 


\section{Voorwoord}

Het Nederlandse poldermodel werd eind jaren go van de vorige eeuw nationaal en internationaal bejubeld vanwege de zeer goede prestaties van de Nederlandse economie en arbeidsmarkt, en vanwege de grote rol van overleg, beleidsleren en consensusvorming tussen vakbonden, werkgeversorganisaties en de overheid in het ontwerpen en uitvoeren van economische en sociale hervormingen. Jelle Visser en Anton Hemerijck spraken in hun boek uit 1997, dat de ommekeer van de gestagneerde economie en hoge werkeloosheid van de jaren 80 naar het succes van de jaren 90 analyseerde, dan ook over A Dutch Miracle, een Nederlands mirakel waarmee de rest van Europa in korte tijd werd ingehaald en voorbijgestreefd.

Tijdens een bijeenkomst bij Instituut Gak kwam de vraag op tafel hoe het poldermodel er vandaag de dag voorstaat, na al de ingrijpende veranderingen in de economie, maatschappij en politiek van de afgelopen twintig jaar. In deze twintig jaar is het poldermodel niet alleen bejubeld maar ook flink bekritiseerd en zelfs regelmatig doodverklaard. Al pratende ontstond het idee om een groep auteurs uit verschillende academische disciplines (sociologie, economie, geografie, recht, politieke wetenschappen) en ook uit de praktijk van de sociale partners bij elkaar te brengen om hun licht te laten schijnen over het poldermodel in de eenentwintigste eeuw. Het resultaat ligt hier voor $u$. De hoofdstukken analyseren verschillende aspecten van het poldermodel en stellen zich daarmee ook de vraag hoe het gaat met Nederland wat betreft democratie, economie, werk en welvaart. Op deze manier wil deze bundel bijdragen aan het debat over hoe Nederland ervoor staat, welke kanten we op kunnen of moeten in de toekomst met ons sociaaleconomisch beleid en wat de rol daarin is van de overheid, sociale partners en andere actoren.

Deze bundel was niet mogelijk geweest zonder de steun van Instituut Gak en met name van Boudien Krol en Bert de Jong, waarvoor hartelijk dank. Dank ook aan Sean Stevenson, Maisha van Pinxteren en Angelique Lieberton voor hun waardevolle assistentie bij onderzoek en organisatie en aan Lou Keune en Frank Tros voor het meelezen. En natuurlijk aan de medeauteurs voor hun inspirerende bijdrages!

\section{Maarten Keune}

Utrecht, februari 2016 



\section{$1 \quad$ Inleiding}

De legitimiteit van het poldermodel in de eenentwintigste eeuw

\section{Maarten Keune}

In het Nederlandse poldermodel onderhandelen verenigingen van werkgevers en werknemers en de overheid over sociaaleconomisch beleid en arbeidsvoorwaarden met als doel compromissen te bereiken over de inhoud van dit beleid en het onderling te coördineren. Het boek $A$ Dutch Miracle van Jelle Visser en Anton Hemerijck uit 1997 analyseerde de rol van onderhandelingen, coördinatie en consensus in Nederland en stelde vast dat dit cruciale factoren zijn geweest in het aanpakken van de lage groei en hoge werkloosheid van begin jaren 80 , en in de goede performance van de Nederlandse economie en arbeidsmarkt in de jaren 9o. Ze lieten zien hoe er, via geïnstitutionaliseerd en informeel overleg, op nationaal niveau sociale akkoorden en andere overeenkomsten werden gesloten en gezamenlijk beleid werd uitgezet met betrekking tot lonen, arbeidsmarkt en sociale zekerheid. Gezamenlijk beleidsleren, en vooral de bereidheid hiertoe van de kant van de vakbeweging, speelde hierbij volgens Visser en Hemerijck een grote rol. Door de corporatistische verwevenheid van de belangen van de overheid en de sociale partners werden de noodzakelijk geachte hervormingen van de arbeidsmarkt en het socialezekerheidsstelsel mogelijk - niet zonder conflict, maar vaak toch zonder veel oppositie. De werkgevers- en werknemersorganisaties spraken op centraal niveau voor hun leden, en het afgesproken beleid werkte vervolgens op decentraal niveau door in de cao-afspraken in de verschillende sectoren. Op die manier, zo beargumenteren Visser en Hemerijck, versterkten zij het concurrentievermogen van Nederland en kon deze kleine en open economie flexibel omgaan met schommelingen in de internationale economie en toch voldoende zekerheden bieden door middel van een goed ontwikkelde welvaartsstaat - een welhaast paradigmatisch voorbeeld van de small states in world markets van Peter Katzenstein (1985). Zodoende werd het poldermodel zeer effectief, en daardoor in hoge mate legitiem geacht in Nederland, en werd het ook als voorbeeld gezien door menig commentator en beleidsmaker in het buitenland.

$\mathrm{Nu}$, twee decennia later, is het tijd voor een hernieuwde analyse van de rol en positie van het poldermodel in de besluitvorming over en besturing 
van de Nederlandse economie, arbeidsmarkt en sociale zekerheid. In die twintig jaar is de context waarin het poldermodel opereert grondig veranderd. De wereldeconomie is diepgaand gefinancialiseerd met een toenemend gewicht van financiële markten, financiële producten en financiële instellingen, die gezamenlijk een zeer invloedrijk maar ook instabiel en crisisgevoelig financieel stelsel vormen. Met een relatief zeer grote financiële sector is Nederland extra kwetsbaar in dit opzicht (zie Engelen in deze bundel). Nederland is in de afgelopen decennia ook een voorloper geworden van wat Colin Crouch (2009) geprivatiseerd keynesianisme noemt, waarbij consumptie in hedendaags kapitalisme niet meer op peil gehouden wordt door anticyclische overheidsuitgaven (en dus publieke schulden), maar door private schulden, vooral bestaande uit hypotheken. Ook is het aandeel van diensten in de economie flink gestegen en is het aandeel van de industrie sterk gedaald, terwijl de rol van multinationale ondernemingen, waar nationale democratische en neocorporatistische instituties maar moeilijk grip op krijgen (Crouch, 2011), is toegenomen in de wereldeconomie én in Nederland, waar ze inmiddels goed zijn voor bijna twee miljoen banen en twee derde van de omzet van het bedrijfsleven (CBS, 2015). Daarnaast is de Europese Unie sinds eind jaren 90 zowel verbreed, met de toetreding van dertien nieuwe lidstaten, als verdiept, met een verregaande overdracht van soevereiniteit van het nationale naar het Europese niveau, in het bijzonder wat betreft economisch en monetair beleid. Dit heeft geleid tot een grotere Europese interne markt met maar een beperkte sociale dimensie en gevoelig voor regime competition (Keune, 2012), een veel grotere rol voor Centraal- en Oost-Europese migranten op de Nederlandse arbeidsmarkt, en een substantiële beperking van de beleidsvrijheid van de Nederlandse politieke actoren. Het is dan ook de vraag welke rol het poldermodel kan spelen in zo'n gefinancialiseerde en geëuropeaniseerde diensteneconomie waarin multinationals een hoofdrol spelen. Zijn de nationale neocorporatistische instituties nog wel in staat om de economie te sturen en groei en werkgelegenheid te stimuleren? En daarbij de welvaartsstaat op peil te houden?

Naast een veranderende context staan ook de actoren van het poldermodel regelmatig ter discussie. Ze worden verweten aan achterkamertjespolitiek te doen, weinig transparant te opereren en met eindeloos overleg en zoeken naar consensus noodzakelijk hervormingsbeleid eerder tegen te houden dan mogelijk te maken. Politieke partijen zoals de VVD, D66 en het CDA, en met name hun jongerenorganisaties, trekken het democratisch gehalte van het poldermodel regelmatig in twijfel en claimen dat regering en parlement leidend moeten zijn in de politiek. Zij 
zijn van mening dat, omdat werkgeversorganisaties en vakbonden niet democratisch gekozen zijn, ze geen sleutelrol in het ontwerpen en uitvoeren van sociaaleconomisch beleid mogen bekleden. Tevens krijgen vooral vakbonden maar ook werkgevers regelmatig het verwijt niet representatief te zijn, voornamelijk op te komen voor deelbelangen, en het algemeen belang en de zwakkeren in de samenleving te negeren. Het poldermodel wordt dan ook regelmatig verweten niet meer van deze tijd te zijn en is al menigmaal doodverklaard.

Tegelijkertijd lijkt de polder springlevend. De Sociaal-Economisch Raad (SER) en de Stichting van de Arbeid (StvdA) zijn actief als altijd, cao's hebben een stabiele dekkingsgraad van rond de 80 procent van alle werknemers, het aanvullend pensioen wordt door de sociale partners gemanaged, en met enige regelmaat wordt er een sociaal akkoord afgesloten. Wat is dan de status van het poldermodel anno 2016? Stervende of springlevend? Uit de tijd of ferm aan het roer van de economie? Deze bundel wil een bijdrage leveren aan dit debat door de legitimiteit van het poldermodel onder de loep te nemen. Legitimiteit wordt hier in navolging van Vivien Schmidt (2013) breed gezien en onderverdeeld in outputlegitimiteit, oftewel de effectiviteit van het model; inputlegitimiteit, oftewel de legitimiteit van de actoren van het model en de mate waarin ze de burgers vertegenwoordigen; en proceslegitimiteit (throughput legitimacy), oftewel de kwaliteit van de governance van het model in termen van transparantie en efficiency van processen, en onderling vertrouwen en samenwerking tussen de actoren. De hoofdstukken in deze bundel analyseren de input-, output- en proceslegitimiteit van het hedendaagse poldermodel aan de hand van verschillende dimensies: het democratisch gehalte van het poldermodel (Braun) en de representativiteit van de actoren (De Beer), de rol van sociale akkoorden (Hemerijck en Van der Meer) en hun invloed op arbeidswetgeving (Boonstra), de doorwerking van centrale afspraken in cao's (Verhoeff), de hervormingen van het pensioenstelsel (Van der Zwan), de oorzaken en gevolgen van de vergaande financialisering van de Nederlandse economie (Engelen), en de prestaties van de Nederlandse economie en arbeidsmarkt (Visser; De Beer).

In dit inleidende hoofdstuk worden de bovengenoemde onderwerpen in een breder kader geplaatst en worden de inzichten van de hoofdstukken samengebracht. In de volgende paragraaf worden de belangrijkste historische, discursieve en institutionele fundamenten van het poldermodel besproken. Vervolgens worden in de daaropvolgende paragrafen de outputlegitimiteit, inputlegitimiteit en proceslegitimiteit van het model geanalyseerd. We sluiten af met een conclusie. 


\section{Historische, discursieve en institutionele fundamenten van het poldermodel}

Zoals eerder aangegeven komen in het Nederlandse poldermodel werkgevers, werknemers en overheid bij elkaar om te overleggen en te onderhandelen over sociaaleconomisch beleid en arbeidsvoorwaarden. In dit neocorporatistische model deelt de Nederlandse staat zijn politieke beslissingsmacht met deze belangengroepen, die fungeren als staatstragende Kräfte die expertise, draagvlak en implementatiecapaciteit kunnen leveren (Crouch, 1993; Streeck, 1992; Lehmbruch en Schmitter, 1982). Deze belangengroepen worden geacht naast hun eigen belang ook het algemeen belang na te streven en compromissen te bereiken. Maar wat houdt deze actoren bij elkaar en zorgt ervoor dat ze niet continu in conflict met elkaar komen? Op basis waarvan zijn zij bereid tot langdurige samenwerking en tot het zoeken van compromissen, zoals ze nu alweer doen sinds het einde van de Tweede Wereldoorlog, hoewel in mindere mate in de periode 1964-1981 (Tros et al., 2006)? Hier worden drie factoren kort besproken, die gezien kunnen worden als fundamenten van het hedendaagse poldermodel: de historische achtergrond, de discursieve grondslagen en de institutionele kenmerken.

\section{Historische fundamenten}

De eerste factor die vaak aangehaald wordt, zijn de historische wortels van het poldermodel. Een groot aantal auteurs beweert dat samenwerken, compromissen zoeken, het delen van politieke macht en het geven en nemen historische kenmerken van de Nederlandse maatschappij zijn, vanaf de gezamenlijke strijd tegen het water en het besturen van de polders in de late middeleeuwen, via de verzuiling van de Nederlandse maatschappij en de noodzaak tot samenwerking tussen de zuilen, tot het hedendaagse model (o.a. Prak en Van Zanden, 2013; Lendering, 2005). Prak en Van Zanden (2013) geven aan dat het model gedurende de eeuwen fundamentele veranderingen heeft ondergaan, met drie belangrijke fases waarin er steeds een poldermodel ontstond dat paste bij de dominante economische activiteiten: eerst de agrarische economie, dan de handelseconomie en vervolgens de industriële economie. Het hedendaagse poldermodel behoort tot die laatste periode en vindt zijn oorsprong in de wederopbouw na de Tweede Wereldoorlog (Tros et al., 2006), in eerste instantie gekenmerkt door een centraal geleide loonpolitiek en, sinds het Akkoord van Wassenaar (1982), door een beperktere rol voor de overheid en een hoofdrol voor werkgeversorganisaties en vakbonden. De continuïteit van het poldermodel is echter geen gegeven 
en het zijn vaak nieuwe actoren geweest die het in nieuwe vorm hebben gereproduceerd (Prak en Van Zanden, 2013). Anderen gaan nog een stap verder en geven aan dat het polderbestuur van rond de zestiende eeuw en het huidige poldermodel weinig met elkaar van doen hebben en dat de Nederlandse geschiedenis ook vol is van conflicten en strijd (Bos et al., 2007; Dam et al., 2014). Vanuit deze optiek is het poldermodel geen empirisch gegronde typering van de Nederlandse samenleving door de eeuwen heen, maar eerder de uitkomst van hedendaagse mythevorming en pogingen tot het creëren van een nationale identiteit.

\section{Discursieve fundamenten}

Dit leidt ons naar de tweede factor, de discursieve grondslagen van het hedendaagse poldermodel. Hier gaat het om de definitie van het algemeen belang, van de problemen die beleid moet oplossen en van de manier waarop dit het best gedaan kan worden. Hier is het opvallend dat het grootste deel van de politieke en economische elite een aantal overtuigingen lijkt te delen en in de afgelopen decennia nauwelijks ter discussie heeft gesteld (Becker en Hendriks, 2008; Hendriks, 2010). De kerngedachte is dat de Nederlandse welvaart staat of valt met een internationaal concurrerend bedrijfsleven, dat de basis vormt voor economische groei en meer werkgelegenheid. Daarnaast worden ook 'gezonde' overheidsfinanciën (oftewel beperkte tekorten en schulden) als een voorwaarde voor groei en welvaart gezien. Concurrentievermogen en gezonde overheidsfinanciën moeten worden nagestreefd met zo min mogelijk sociale conflicten en behoorlijke sociale voorzieningen. Maar de respectievelijke manoeuvreerruimte wordt bepaald door de economische prestaties van Nederland, die afhankelijk zijn van ontwikkelingen op de wereldmarkt, en van de macro-economische context (Woldendorp, 2013; Visser en Hemerijck, 1997). Een hoofdrol is in deze redenering weggelegd voor loonmatiging, gezien als een noodzakelijke voorwaarde voor concurrentievermogen (Hendriks, 2010; Visser en Hemerijck, 1997). Ook werkgelegenheid krijgt een hoofdrol toebedeeld, want hoe meer mensen er werken, hoe minder druk er is op de welvaartsstaat en dus op de overheidsfinanciën. Socialezekerheids- en arbeidsmarktbeleid moeten daarom activerend zijn en afhankelijkheid van de welvaartsstaat moeten worden vervangen door zelfredzaamheid door middel van werk. Deze gedachtegang wordt ondersteund door het Centraal Planbureau (CPB), veelal gezien als de voornaamste autoriteit op het gebied van economische analyse, en al decennialang fervent aanhanger van de gedachte dat loonmatiging het recept is voor een sterkere internationale concurrentiepositie en 
dus werkgelegenheidsgroei (Becker en Hendriks, 2008). Een laatste element is dat overleg en geven en nemen de Nederlandse manier is om deze doelen te bereiken en dat het poldermodel hier een functionele manifestatie van is.

Deze kerngedachte wordt tot op vandaag de dag aangehangen door een epistemic community (Haas, 1992) - gevormd door de meeste politieke partijen, de vertegenwoordigers van werknemers en werkgevers, het $\mathrm{CPB}$ en het grootste deel van de academici (Becker en Hendriks, 2008) - en wordt bekrachtigd door de SER (o.a. SER, 2012). Zij stellen deze visie nauwelijks ter discussie en staan ook niet open voor alternatieve zienswijzen, die bijvoorbeeld aangeven dat het overschot op de Nederlandse handelsbalans al ongekend groot is, die de negatieve effecten van loonmatiging op de binnenlandse bestedingen of op innovatie benadrukken, of die onderstrepen dat loonmatiging leidt tot een schevere verdeling van inkomen tussen werknemers aan de ene kant en werkgevers en aandeelhouders aan de andere kant (Engelen, in deze bundel; De Geus, 2014). Typerend voor deze visie zijn de teksten van de diverse sociale akkoorden die in de afgelopen decennia zijn afgesloten. Zo stelde het Nieuwe Koers Akkoord van 1993 het volgende:

De economische situatie is uiterst zorgelijk. De vooruitzichten voor de middellange termijn wijzen erop dat zonder structurele aanpassingen zich geen of onvoldoende herstel kan voordoen van economische groei, rendements- en concurrentiepositie. (...) Noodzakelijk onderdeel van een economische strategie is een loonkostenontwikkeling, die verantwoord is vanuit het oogpunt van de rendements- en concurrentiepositie van de desbetreffende bedrijfstak of onderneming.

Minder lang geleden, en midden in de recente crisis, die niets met verloren concurrentiekracht had te maken, haalden de sociale partners het polderdiscours weer van stal en concludeert het Akkoord in de Stichting van de Arbeid van 25 maart 2009 dat:

Doel van een sociaal akkoord is een bijdrage leveren aan het structureel sterk en gezond houden van onze economie. Zoveel mogelijk mensen moeten aan het werk blijven en waar dat niet volledig lukt, moet de periode van werkloosheid zo kort mogelijk duren. Een samenleving met een sterk oplopende en blijvende werkloosheid is een bedreiging voor de sociale cohesie en zal bestaande spanningen versterken. Dat kan alleen worden voorkomen door behoud van sterke ondernemingen in Nederland, die concurrerend en innovatief zijn. Door daaraan - samen met de overheid - te blijven werken, achten de sociale partners het mogelijk om met 
vereende krachten de crisis het hoofd te bieden. Speciale zorg voor de zwakkeren in de samenleving is daarbij nodig.

Dit discours, ingezet in 1945, fungeert als het bindmiddel voor het poldermodel, dat de actoren bij elkaar houdt en hen van een gezamenlijke visie en beleidskader voorziet. Ook definiëren zij hun belangen grotendeels binnen het kader van deze visie. Dit wil niet zeggen dat er geen conflicten zijn en dat ze hun belangen als identiek beschouwen, maar wel dat ze gedeelde uitgangspunten hebben en er ruimte voor compromissen is. Degenen die zich buiten dit discours plaatsen met afwijkende gezichtspunten of beleidsvoorstellen, worden makkelijk weggezet als onverantwoordelijk of irrationeel. Dit overkomt met name de FNV nog weleens als zij, in de optiek van werkgevers of overheid, 'onverantwoordelijke' eisen stelt in cao-onderhandelingen.

\section{Institutionele fundamenten}

De derde factor zijn de instituties die het poldermodel stabiliteit en continuïteit verschaffen. Deze instituties geven werkgeversorganisaties en vakbonden een cruciale beleidsmakende en coördinerende functie in het model. Ze hebben hun vaste rol als adviseurs in de SER, waarin ze een continue dialoog met elkaar, kroonleden, andere academische experts en de beleidsgemeenschap voeren. Adviezen van de SER wegen nog immer zwaar en de overheid kan ze niet zomaar aan haar laars lappen. In de StvdA komen werkgevers en vakbonden met grote regelmaat bij elkaar om te overleggen en te onderhandelen over sociaaleconomische thema's. Vanuit de StvdA communiceren ze ook gezamenlijk naar de overheid. Deze twee instituties geven werkgevers en bonden een belangrijke invloed op het sociaaleconomisch beleid van Nederland. Met enige regelmaat wordt deze invloed vastgelegd in een sociaal akkoord. Beginnend met het Akkoord van Wassenaar zijn er sinds 1982 niet minder dan 18 sociale akkoorden gesloten, ongeveer om het jaar één (Van der Meer en Visser, 2010; Hemerijck en Van der Meer, in deze bundel). Daarnaast zijn er sinds 2013 nog een vijftal pragmatische ad-hocakkoorden gesloten met een breed scala aan maatschappelijke organisaties, inclusief bonden en werkgevers, over specifieke thema's: zorg, onderwijs, wonen, techniek en energie (voor een analyse zie Hemerijck en Van der Meer, in deze bundel).

Misschien wel de belangrijkste institutionele fundering wordt gevormd door de vele cao's die jaarlijks worden afgesloten, meestal voor bedrijfstakken, en in beperkte mate ook op ondernemingsniveau. De dekkingsgraad 
van deze cao's (het percentage werknemers dat onder een cao valt) is hoog en schommelt al 35 jaar tussen de 75-9o procent (De Beer, in deze bundel), als resultaat van een hoge organisatiegraad van de werkgevers en van het feit dat bedrijfstakcao's in de meeste gevallen algemeen verbindend verklaard worden door de minister van Sociale Zaken en Werkgelegenheid (Boonstra, in deze bundel). In de cao's worden afspraken gemaakt over arbeidsvoorwaarden, arbeidsorganisatie, opleidingen en vele andere aspecten van werk. Via het proces van doorwerking zijn de cao's van belang als implementatie-instrument van sociale akkoorden (Verhoeff, in deze bundel). De continue interactie tussen werkgevers en vakbonden in het kader van cao-onderhandelingen en de implementatie ervan leiden ertoe dat de partijen elkaar goed kennen, elkaars belangen goed kunnen inschatten en, met ups en downs, behoorlijk veel vertrouwen in elkaar hebben.

Werkgevers en vakbonden hebben ook een centrale rol in het pensioensysteem (Van der Zwan, in deze bundel). Gezamenlijk zijn zij, binnen de kaders gesteld door de wet, verantwoordelijk voor het aanvullend pensioen, wat als aandeel in het totale pensioen vergelijkbaar is met de AOW. Ze besturen de bedrijfstakpensioenfondsen en ondernemingspensioenfondsen, die gezamenlijk zo'n go procent van de werknemers dekken.

Gezamenlijk geven de SER, StvdA, de cao's en de pensioenfondsen aan werkgevers en vakbonden een hoofdrol in de economie, arbeidsmarkt en sociale zekerheid. Dit betekent niet dat de geïnstitutionaliseerde positie van werkgevers en bonden niet aan verandering onderhevig is. Sinds de jaren 90 hebben de sociale partners een aantal belangrijke institutionele posities, en daarmee aanzienlijke invloed verloren, met name in de uitvoering van de sociale zekerheid, de arbeidsvoorziening en de bedrijfs- en productschappen (De Beer, in deze bundel; Van Gestel et al., 2009). Daarnaast zijn de afgelopen jaren de eerdergenoemde thematische ad-hocakkoorden geïntroduceerd, waarbij de overheid afspraken maakt met een hele reeks aan maatschappelijke actoren en waarin de sociale partners niet per se de hoofdrol spelen. Ook zijn de afspraken in de bedrijfstak-cao's steeds meer raamwerk- of minimumafspraken geworden die op bedrijfsniveau uitgewerkt kunnen worden naar gelang de lokale behoeften ('maatwerk'), wat de directe invloed van de centrale werkgeversorganisaties en vakbonden op arbeidsvoorwaarden verminderd heeft. Het is de vraag of dit soort ontwikkelingen in de toekomst zullen doorzetten en de positie van (sommige van de) sociale partners verder zullen aantasten. Hier lijkt de meeste spanning te bestaan binnen het cao-systeem, waar het afsluiten van cao's steeds moeilijker lijkt te worden. Dit zal sterk afhangen van de vraag hoe de legitimiteit van het 
poldermodel en van de verschillende actoren daarbinnen zich ontwikkelt. Dit wordt in de volgende paragrafen besproken.

\section{Outputlegitimiteit}

Outputlegitimiteit van een politiek systeem refereert aan de probleemoplossende capaciteit ervan, oftewel de capaciteit om effectief beleid te maken dat bijdraagt aan het oplossen van maatschappelijke problemen en het nastreven van het algemeen belang (Scharpf, 1999; Schmidt, 2013; Van Kersbergen en Van Waarden, 2001). Het succes van het Nederlandse poldermodel zoals dat eind jaren 90 werd gevierd was voornamelijk gebaseerd op de output die het produceerde. Het mirakel dat Visser en Hemerijck analyseren in A Dutch Miracle (1997) was allereerst een werkgelegenheidswonder, bestaande uit een sterk verbeterde werkgelegenheid en sterk verminderde werkloosheid, zowel in vergelijking met de jaren 80 als met de meeste andere westerse landen. Dit ging samen met een flinke verbetering van de overheidsfinanciën. Zij zagen dit mirakel als de uitkomst van effectief beleid, bestaande uit loonmatiging, de modernisering van het sociale stelsel en activerend arbeidsmarktbeleid. Overigens gaven ze duidelijk aan dat het mirakel ook deels het gevolg was van fortuna, met name wat betreft de snel groeiende praktijk van deeltijdbanen en de groei van de arbeidsintensieve dienstverlening. Tevens gaven ze aan dat het succes ook zwakke kanten kende, met name een hoog niveau van langdurige werkloosheid en de geringe kansen voor ongeschoolden en allochtonen.

Hoe staat het er twintig jaar later voor met de outputlegitimiteit van het poldermodel? In hun respectievelijke bijdrages aan deze bundel analyseren Visser en De Beer de standaardindicatoren zoals economische groei, werkgelegenheid, werkloosheid en productiviteit om de ontwikkeling van de prestaties van Nederland in de afgelopen decennia te evalueren en te vergelijken met de ons omringende landen. Ze concluderen dat Nederland in de jaren 90 koploper was wat betreft de groei van de werkgelegenheid, daling van de werkloosheid en economische groei. Met name de werkgelegenheidsgraad steeg zeer snel naar hoge hoogten. Na 2000 verzwakte de groei op alle fronten en presteerde Nederland in vergelijkend perspectief maar heel matig en zag het de omringende landen dichterbij komen.

Van de ene kant lijkt het er dan ook op dat, zoals Paul de Beer aangeeft, de geijkte Nederlandse instrumenten zijn uitgewerkt, waardoor de outputlegitimiteit van het poldermodel onder druk kan komen te staan. Tegelijkertijd, hoewel de groei er voor een groot deel uit is, staat Nederland nog steeds hoog 
op alle lijstjes wat betreft inkomen per hoofd van de bevolking en werkgelegenheid (tabel 1.1). Ook zijn de loonongelijkheid (Visser, in deze bundel) en de inkomensongelijkheid (Gini-coëfficiënt, tabel 1.1) vooralsnog relatief beperkt. Visser ziet deze beperkte ongelijkheid als een van de uitkomsten van het poldermodel, dat past in een algemenere analyse die een negatief verband laat zien tussen (loon)ongelijkheid en de dekkingsgraad van cao's (Visser et al., 2015). De publieke schulden zijn ook relatief gering en de polder levert de beloofde sociale vrede: het jaarlijks aantal stakingsdagen in Nederland is enorm klein (Verhoeff, in deze bundel).

Maar andere indicatoren geven een minder rooskleurig beeld van de prestaties van het poldermodel. Zo is de werkgelegenheidsgraad in Nederland het hoogste van de zes landen in tabel 1.1, maar de fulltime werkgelegenheidsgraad is het laagste, als gevolg van het zeer hoge percentage parttime banen. Dit duidt aan de ene kant op een zeer sociale verdeling van het werk in Nederland over de beroepsbevolking. Maar het duidt ook op een beperkte capaciteit om additioneel werk te genereren. De Nederlandse economie is dus wel een banenmachine maar geen werk-genererende machine. Tevens is de werkloosheid in de afgelopen jaren behoorlijk opgelopen en is de groei van de productiviteit per uur maar zeer beperkt en beduidend lager dan in Frankrijk, Denemarken en vooral Duitsland.

Vragen kunnen ook gesteld worden wat betreft de kwaliteit van het werk. Werk in Nederland is steeds onzekerder, gezien de sterke groei van het gebruik van tijdelijke contracten: van 13,8 procent in 2000 tot 20,2 procent in 2013, een stuk hoger dan in de omringende landen (tabel 1.1). Dit betreft vooral jongeren onder de 25 jaar, van wie in 2013 53,1 procent een tijdelijke baan had, in vergelijking met 35,3 procent in 200o. Ook zijn tijdelijke contracten steeds minder een opstapje naar een vaste baan: aan het einde van de jaren 90 kreeg 43 procent van de werknemers met een tijdelijk contract binnen een jaar een vast contract; in de periode 2008-2011 daalde dit naar 28 procent per jaar (Muffels, 2013). Steeds meer jongeren komen dus vast te zitten in opeenvolgende tijdelijke contracten, nu en dan onderbroken door periodes van werkloosheid, met alle negatieve sociale en economische gevolgen van dien. De flexibilisering van de arbeidsmarkt wordt verder gevoed door de snelle groei van het aantal zelfstandigen zonder personeel (zzp), waarvan een deel moeite heeft om aan werk te komen, voor zeer lage tarieven werkt en dus een laag inkomen heeft, zonder sociale verzekeringen werkt en directe concurrentie aangaat met werknemers. Zo blijkt uit een enquête van de Stichting ZZP Nederland (2014) dat een derde van de zzp'ers minder dan 20.000 euro per jaar verdient, dat twee derde niet verzekerd is voor arbeidsongeschiktheid, en dat 6 o procent geen pensioen opbouwt als 


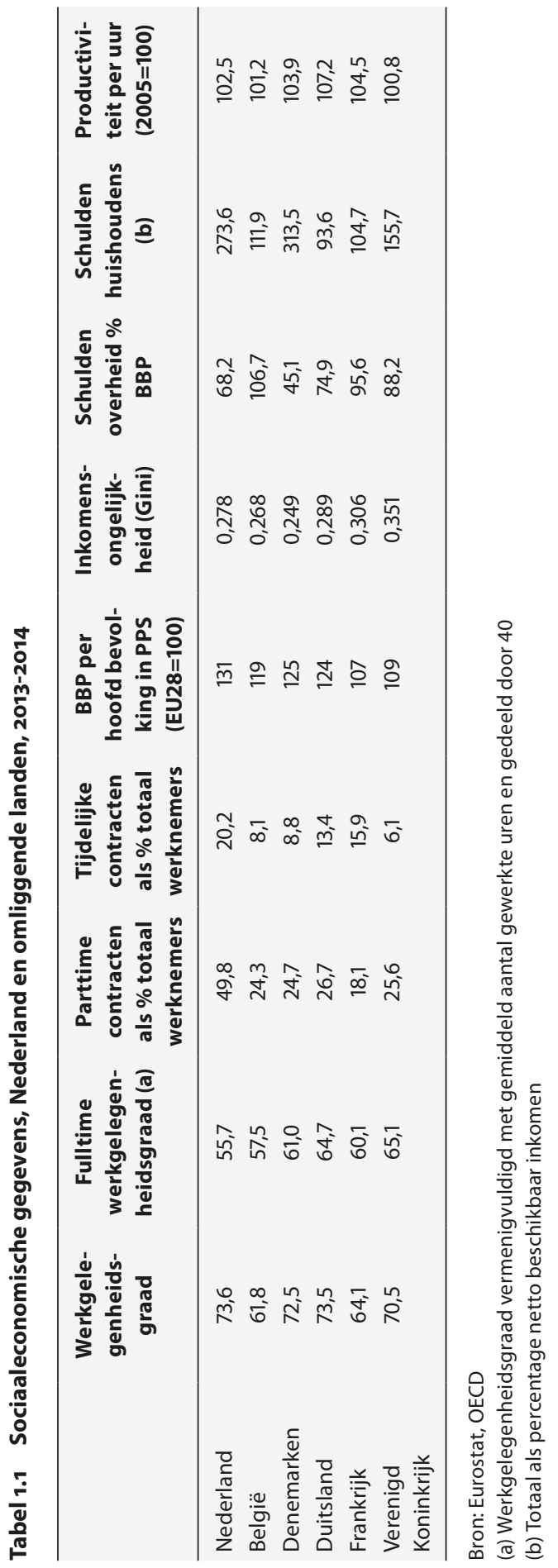


zelfstandige. Verder neemt flexibilisering de vorm aan van nieuwe types arbeidsrelaties zoals contracting of payrolling, en het gebruik van (illegale) schijnconstructies of van arbeidsmigranten die onder zeer slechte omstandigheden werken (Boonstra, in deze bundel). Het sociaal akkoord van 2013 stelt dan ook '... dat er in toenemende mate sprake is van "doorgeschoten flexibiliteit", dat wil zeggen arbeidsrelaties waarvan de noodzaak dubieus is en/of waarbij de vormgeving volkomen onevenwichtig is ten nadele van de werknemer (Stichting van de Arbeid, 2013 p. 20).'

Daarnaast zijn zowel loon- als inkomensongelijkheid vooralsnog beperkt, maar vertonen ze wel een duidelijk stijgende lijn, voornamelijk omdat de topinkomens weglopen van de rest en de inkomens van uitkeringsgerechtigden onder druk staan. Deze verschillen zijn nog veel groter als vermogen meegenomen wordt in de analyse (Kremer et al., 2014). Dit komt onder andere door de continue praktijk van loonmatiging voor het grootste deel van de werknemers (Verhoeff, in deze bundel), maar niet voor de top, die meestal niet onder de cao valt. Ook heeft de huidige regering flinke bezuinigingen op zorg en sociale zekerheid doorgevoerd, die vooral de laagste inkomens treffen, en daalt voor een groot aantal gepensioneerden de waarde van hun pensioen.

Verder zien we dat huishoudens in Nederland (en Denemarken) zeer hoge schulden hebben, die in 2013 met 274 procent van het netto beschikbaar inkomen 85 procent hoger lagen dan in 2000 en drie keer zo hoog waren als in Duitsland (tabel 1.1). Publieke schulden zijn dus inderdaad omgezet in private schulden. Deze schulden komen voornamelijk voort uit de torenhoge hypotheeklasten en drukken steeds zwaarder op de consumptie, binnenlandse vraag en groei (voor meer details zie Engelen, in deze bundel). Dit past in het bredere patroon van diepgaande financialisering van de economie, die het zeer kwetsbaar maakt voor internationale financiële schommelingen en crises (ibid.).

Een eenduidig oordeel over de Nederlandse prestaties is dus moeilijk te gegeven: op een aantal fronten doet Nederland het prima, op andere zijn de ontwikkelingen negatief. Wel duidelijk is dat er anno 2016 geen reden meer is voor een jubelstemming zoals eind jaren 9o, en dat het 'mirakel' voorbij is. Het poldermodel is niet meer de beste student van de klas. Maar dat hoeft natuurlijk ook niet en het lijkt een illusie dat je als land langdurig voor de rest uit kunt lopen. Wel is er vanuit de optiek van de outputlegitimiteit de noodzaak om meer aandacht te besteden aan beleidsleren, volgens Visser en Hemerijck (1997) het sterke punt van het model. Waar zij aangaven dat het succes van de jaren 80 en 90 vooral te danken was aan de bereidheid van de vakbeweging om te leren en te veranderen, lijkt het vandaag de dag 
cruciaal dat ook werkgevers en overheid zich openstellen voor alternatieve gezichtspunten. Als het poldermodel haar outputlegitimiteit wil behouden zal het moeten inzien dat het traditionele recept van loonmatiging en gezonde overheidsfinanciën niet (meer) voldoet om zowel de economie en arbeidsmarkt dynamisch te houden als kwalitatief goede banen te creëren en de welvaart op peil te houden. Er zal meer aandacht gegeven moeten worden aan beleidsalternatieven die, bijvoorbeeld, flexibilisering, onzekerheid en ongelijkheid reduceren, de koopkracht en binnenlandse bestedingen versterken, concurrentievermogen stimuleren door in plaats van loonmatiging productiviteitsgroei en innovatie te bevorderen - $\mathrm{Ne}$ derland is volgens data van de Europese Commissie (2013) een innovation follower in plaats van een innovation leader zoals Duitsland, Denemarken, Finland en Zweden -, en die de kwetsbaarheid voor schokken en crises in het internationale financiële systeem beperken.

Een aantal, zij het vaak aarzelende, stappen in die richting, die ook de institutionele logica van het poldermodel volgen, zijn in de afgelopen jaren al gezet, al zijn het vooralsnog meer woorden dan daden. Zoals eerder aangegeven heeft het sociaal akkoord van 2013 de doorgeslagen flexibilisering op de agenda gezet, en de eerste beleidsinitiatieven zijn genomen, bijvoorbeeld om schijnconstructies tegen te gaan of ketenverantwoordelijkheid te bevorderen, voornamelijk met minister Asscher als initiator. In een aantal sectoren zijn de sociale partners bezig met het in de cao opnemen van minimumtarieven en/of de verplichting tot het verzekeren voor arbeidsongeschiktheid voor zzp'ers, en zowel werkgevers als vakbonden proberen de zelfstandigen te organiseren. De Algemene Werkgeversvereniging Nederland (AWVN) heeft haar leden onlangs opgeroepen om zich niet alleen druk te maken om winst, maar ook om hun maatschappelijke verantwoordelijkheid en de sociale kant van de bedrijfsvoering te versterken, samen met de vakbond, en de mens meer centraal te zetten (AWVN, 2015). Ook de topinkomens zijn inmiddels onderdeel van het publieke debat en de publieke verontwaardiging, maar met uitzondering van de limiet op de topsalarissen in de (semi-)publieke sector is hier nog weinig bereikt. De typische polderoplossing zou zijn om topsalarissen onder de cao te brengen, maar voorlopig lijkt dat niet te gebeuren.

Wat de overheidsfinanciën en de kwetsbare gefinancialiseerde economie betreft is er minder nieuws onder de zon. Dit komt voor een deel door de transfer van beleidssoevereiniteit naar het Europese niveau. Hierdoor zijn de beleidsopties van het nationale poldermodel beperkter, vooral op het gebied van macro-economisch beleid en de begrotings- en schuldencriteria. Ook wat betreft het internationale financiële stelsel worden steeds meer van 
de regels gemaakt in Brussel, Frankfurt, Bazel, Londen en de VS (Engelen, in deze bundel). Maar hoewel het waar is dat deze Europese en internationale regels moeilijk zijn te beïnvloeden, zijn er toch keuzes mogelijk over hoe met deze regels en hun consequenties om te gaan. Zo is er in de context van EU-begrotingsregels tijdens de recente crisis gekozen voor zwaar aangezette bezuinigingen. Die hebben de binnenlandse vraag en vertrouwen ondermijnd, met als gevolg een relatief grote terugval van de Nederlandse economie en arbeidsmarkt (Visser, in deze bundel). Binnen de Europese regels en vanwege de flexibiliteit die deze in de praktijk hebben laten zien, had men ook kunnen kiezen voor veel beperktere bezuinigingen, om de sociale voorzieningen op peil te houden of te investeren in de toekomst - los van het feit dat de crisis een prima reden was geweest om de regels zelf ter discussie te stellen. Een ander voorbeeld is dat de recente crisis duidelijk heeft gemaakt dat het Nederlandse pensioensysteem extreem kwetsbaar is voor volatiliteit op de financiële markten. Overheid en sociale partners hebben hieruit echter niet de les getrokken dat de invloed van de financiële markten over de pensioenen beperkt moet worden; in plaats daarvan accepteren ze deze kwetsbaarheid grotendeels als onvermijdelijk en leggen ze zich voornamelijk toe op het 'beter uitleggen' van de risico's aan de bevolking (Van der Zwan, in deze bundel). Dit geldt eveneens voor de bredere risico's verbonden aan de financialisering van de Nederlandse economie (Engelen, in deze bundel).

\section{Inputlegitimiteit}

Inputlegitimiteit betreft de legitimiteit van de actoren in een politiek bestel, zowel politieke partijen als belangengroepen, en de mate waarin zij de belangen van burgers vertegenwoordigen (Schmidt, 2013; Scharpf, 1999). Door middel van belangengroepen kunnen burgers een belangrijke en continue rol spelen in politieke processen, een rol die verder gaat dan eens in de zoveel jaar naar de stembus gaan. Wat het poldermodel betreft gaat het hier om de plaats van dit model in het democratische politieke systeem, welke actoren er mee mogen doen, en welke belangen en bevolkingsgroepen zij vertegenwoordigen. Werkgeversorganisaties en vakbonden zijn geprivilegieerde belangengroepen in dit model, die speciale functies en institutionele posities toebedeeld hebben gekregen in de SER en andere adviesorganen, in het pensioenstelsel en in het cao-stelsel. Naast het feit dat dit positieve effecten kan hebben op de prestaties van de economie en arbeidsmarkt, en dus outputlegitimiteit aan het model kan geven, beoogt 
dit het beleid te voorzien van maatschappelijk draagvlak, oftewel steun van (grote delen van) de belanghebbenden bij het beleid. En zoals Braun (in deze bundel) betoogt: 'Een van de belangrijkste pijlers waarop het poldermodel gebaseerd is, is namelijk de notie dat de sociale partners die aanschuiven aan de onderhandelingstafel representatieve belangenbehartigers zijn van niet alleen hun eigen achterban, maar van een breed palet aan sociaaleconomische belangen.'

De geprivilegieerde posities van werkgevers en vakbonden, en daarmee ook het poldermodel, staan regelmatig ter discussie. Critici wijzen erop dat ze niet democratisch zijn gekozen, deelbelangen vertegenwoordigen en geen maatschappelijk draagvlak kunnen leveren, en dat ze het maken van sociaaleconomisch beleid dan ook over moeten laten aan democratisch gekozen politici (o.a. Pechtold, 2013). Tegelijkertijd zoekt de regering de sociale partners met grote regelmaat op om akkoorden af te sluiten, juist met het doel om maatschappelijk draagvlak voor beleid te verzekeren. En waar politiek sterke regeringen dit vooral doen om extra draagvlak te creëren voor beleid dat al door het parlement gesteund wordt, doen regeringen met een minderheid in Tweede of Eerste kamer, zoals het kabinet-Rutte II, dit soms juist om eerst maatschappelijke steun te verwerven en daarmee de Kamer te overtuigen zich achter hun beleid te scharen (Hemerijck en Van der Meer, in deze bundel).

Het poldermodel roept dus vragen op wat betreft het democratische gehalte van het systeem an sich en wat betreft de representativiteit (en legitimiteit) van de actoren in het model. Wat het democratische gehalte betreft is de belangrijkste vraag in hoeverre het poldermodel past bij een parlementaire democratie. Braun (in deze bundel) laat zien dat het antwoord hierop allereerst afhangt van het perspectief op democratie. Vanuit het perspectief van de deliberatieve democratie - die in Nederland de vorm krijgt van consensusbesluitvorming -, waarin de kwaliteit van besluitvorming en beleid centraal staan, is het poldermodel eenvoudig te accepteren. Vanuit het perspectief van de participatieve democratie echter is de geprivilegieerde positie van twee belangengroepen, en dus een ondergewaardeerde positie van alle andere belangengroepen, problematisch, terwijl men vanuit het gezichtspunt van de representatieve democratie kritisch zal zijn over de mate waarin de sociale partners alle sociaaleconomische belangen adequaat vertegenwoordigen (ibid.).

Tegelijkertijd doet het poldermodel formeel gezien niets af aan het primaat van de politiek. Regeringsbeleid blijft allereerst de verantwoordelijkheid van de regering, waarbij het kan besluiten het advies van de SER of andere input van werkgevers en vakbonden over te nemen, aan 
te passen of te negeren; en het is aan de Tweede Kamer om de regering te controleren en eventueel ter verantwoording te roepen (Hemerijck en Van der Meer, in deze bundel). Ook is de regering niet verplicht akkoorden af te sluiten met de sociale partners of om cao's algemeen verbindend te verklaren (avv). Het is aan de politiek om de belangen die worden ingebracht zorgvuldig af te wegen en mee te nemen in hun uiteindelijke beoordeling van beleidsvoorstellen, en om het voortouw te nemen in de inrichting en aansturing van de nationale economie door middel van het overlegmodel, inclusief het democratische gehalte en daarmee het duurzaam functioneren ervan (Braun, in deze bundel).

Wat de representativiteit van de actoren in het poldermodel betreft onderscheidt Braun (ibid.) vier vormen van representativiteit:

1 formele representativiteit, waarbij het gaat om de institutionele regels en procedures op basis waarvan vertegenwoordigers worden gekozen;

2 beschrijvende representativiteit, waarbij het gaat om de gelijkenis tussen bepaalde kenmerken van de vertegenwoordiger en vertegenwoordigden;

3 substantiële representativiteit, waarbij het gaat over hoe goed de vertegenwoordiger de belangen van de vertegenwoordigden behartigt;

4 symbolische representativiteit, waarbij het erom gaat of de vertegenwoordigden zich op een effectieve en faire manier vertegenwoordigd voelen.

\section{Formele representativiteit}

Over formele representativiteit kunnen we kort zijn. De regering is weinig problematisch in de zin van de formele representativiteit, gezien het feit dat zij voortkomt uit een proces van democratische verkiezingen waaraan een behoorlijk percentage van de bevolking deelneemt. Werkgeversorganisaties en vakbonden vallen buiten de formele democratische procedures van de parlementaire democratie en hebben dus een veel beperktere formele representativiteit. Tot op zekere hoogte kan deze formele representativiteit ook gewaarborgd worden door de interne procedures van deze organisaties. Op dit punt zien we in de afgelopen jaren vooral bij de FNV veranderingen die de interne democratie moeten verhogen, met name door het instellen van een ledenparlement.

\section{Beschrijvende representativiteit}

Beschrijvende representativiteit is voor de regering vooral een issue wanneer zij geen meerderheid heeft in de Eerste of Tweede Kamer, en op die 
manier geen meerderheid van de stemmen vertegenwoordigt. Maar het is vooral onderwerp van discussie voor vakbonden en werkgevers, zowel in relatie tot hun directe doelgroepen (werknemers en werkgevers) als tot de gehele bevolking. Wat de doelgroepen betreft is bij de vakbonden allereerst de daling van de organisatiegraad van werknemers belangrijk, van ongeveer een op de drie in de jaren 70 tot een op de zes vandaag de dag (De Beer in deze bundel). Ook zijn er belangrijke (hoewel beperkte) verschillen tussen de samenstelling van het ledenbestand van vakbonden en de totale populatie van werknemers, waarbij oudere werknemers, werknemers in het openbaar bestuur en het onderwijs en, in iets mindere mate, ook autochtonen, mannen, werknemers met een vaste voltijdbaan, en werknemers in grotere bedrijven oververtegenwoordigd zijn (ibid.). Volgens de logica van de beschrijvende representativiteit zou dit kunnen betekenen dat de belangen van deze groepen ook beter vertegenwoordigd worden door de vakbonden, en dat die van werknemers met flexibele en deeltijdcontracten, van jongeren en van werknemers in de ondervertegenwoordigde sectoren minder aandacht krijgen.

De organisatiegraad van werkgevers kan op twee manieren bekeken worden: het percentage werkgevers dat lid is, of het percentage werknemers dat gedekt wordt door de leden. De twee verschillen aanzienlijk. Volgens de Werkgevers Enquête Arbeid 2014 van TNO is 35 procent van de werkgevers lid van een werkgeversvereniging (Emmerik et al., 2014). Dit lidmaatschap lijkt snel te dalen: in 2010 gaf dezelfde enquête nog een lidmaatschap van 49 procent en in 2012 van 42 procent (TNO, 2015). ${ }^{1}$ Van de kleine bedrijven of organisaties met twee tot vier werkzame personen is 27 procent lid, terwijl dit percentage voor werkgevers met meer dan honderd werkzame personen op 64 procent ligt (Emmerik et al., 2014). Dit geeft ook aan dat de daling in lidmaatschap voornamelijk plaatsvindt onder de kleine werkgevers.

In termen van het aantal werknemers dat onder de leden van werkgeversorganisaties valt, is de organisatiegraad beduidend hoger en stabieler: deze ligt sinds het begin van deze eeuw rond de 70 procent, ver boven die van de vakbeweging (De Beer, in deze bundel). Dit is het gevolg van het hoge en stabiele lidmaatschap van de grote werkgevers. Deze organisatiegraad zegt minder over de afspiegeling van de populatie van werkgevers, en meer over het bereik en de invloed van werkgeversorganisaties in de economie en op de arbeidsmarkt. Ook is het van groot belang voor het cao-stelsel. Het is

1 Het is mogelijk dat door de wijze van bevraging deze percentages de werkelijke situatie enigszins onderschatten (De Beer in deze bundel). 
deze hoge organisatiegraad die, samen met de avv, de hoge dekkingsgraad van de cao's in stand houdt.

Vanuit democratisch oogpunt is het ook van belang om te kijken naar de beschrijvende representativiteit van de twee belangengroepen ten opzichte van de bevolking. Tenslotte wordt van hen verwacht dat ze in het poldermodel niet alleen de belangen van hun eigen achterban behartigen, maar ook het algemeen belang dienen. Vanuit dit perspectief is de beschrijvende representativiteit van de vakbonden, met een totaal van rond de 1,5 miljoen leden oftewel zo'n 9 procent van de bevolking, behoorlijk hoog. De FNV is met haar 1,1 miljoen leden een van de allergrootste ledenorganisaties in het land. Ter vergelijking: de regeringspartijen VVD en PvdA hadden begin 2015 respectievelijk 31.000 en $5^{0.000}$ leden $(A D, 16-1-2015)$. Er zijn geen data over het exacte aantal werkgevers of over het aantal leden van werkgeversorganisaties. Het leidt echter geen twijfel dat de leden van werkgeversorganisaties maar een zeer klein percentage van de bevolking uitmaken. Vanuit dit perspectief van de beschrijvende representativiteit kunnen er dan ook vooral bij de werkgevers vragen gesteld worden over hun capaciteit om het algemeen belang te behartigen.

\section{Substantiële representativiteit}

De beschrijvende representativiteit zegt echter niet alles over hoe goed werkgeversorganisaties en vakbonden de belangen van hun doelgroepen of het algemeen belang vertegenwoordigen. Deze substantiële representativiteit hangt af van welke belangen ze in de praktijk behartigen: die van (een deel van) hun leden, van de gehele doelgroep en/of die van de samenleving. Er is hier geen ruimte om het beleid van de beide groepen in detail te bespreken, maar een paar zaken vallen op. Allereerst zijn zowel werkgevers als vakbonden via de SER, sociale akkoorden, cao's, pensioenfondsen, etc. op veel terreinen betrokken bij beleid dat hun leden of directe doelgroepen overstijgt, en dus bij het algemeen belang. Ze doen dit wel vanuit verschillende visies.

VNO-NCW heeft de ambitie om van Nederland het meest welvarende land ter wereld te maken en ziet als middel hiervoor een sterke en concurrerende economie, die werk voor iedereen creëert. Dit wil ze bereiken door het stimuleren van een excellent ondernemings- en vestigingsklimaat. ${ }^{2}$ MKB Nederland heet een vergelijkbare missie, maar specifieker gericht 
op het midden- en kleinbedrijf. ${ }^{3}$ De AWVN ziet zichzelf vooral als een dienstverlenende organisatie voor werkgevers. ${ }^{4}$ Alle drie richten ze zich in eerste instantie voornamelijk op ondernemersbelangen, in de verwachting dat dit ook zal leiden tot een welvarende samenleving. De vakbonden, en met name de FNV en het CNV, zien zichzelf meer als vertegenwoordigers van die samenleving, en niet alleen van werknemers, en formuleren heel brede maatschappelijke missies. Het $\mathrm{CNV}^{\text {' }}$... streeft naar een samenleving waarin mensen zoveel mogelijk gelijke kansen hebben en duurzaamheid een centraal begrip is. ${ }^{5} \mathrm{De}$ FNV maakt zich sterk voor '... een rechtvaardige en solidaire verdeling van werk, welvaart, welzijn en macht. Wij staan voor een duurzaam beheer van de aarde, én voor een sociaal-rechtvaardige oplossing voor de gevolgen van het mondiale milieubeleid op arbeid. ${ }^{6}$

De missies van de werkgeversorganisaties zijn in eerste instantie vooral gericht op ondernemers, al zijn er zeker activiteiten op het maatschappelijke vlak, zoals de huidige campagne om 100.000 mensen met een arbeidsbeperking aan het werk te helpen, onderdeel van het sociaal akkoord van 2013, of sommige onderdelen van het beleid op het gebied van maatschappelijk verantwoord ondernemen. Maar zonder twijfel zijn de missies van de vakbonden breder en meer maatschappelijk. Ook bij de vakbonden hebben de belangen van de leden prioriteit, maar ze komen tevens op voor de belangen van werknemersgroepen en anderen die minder vertegenwoordigd zijn in hun lidmaatschap. Ze onderhandelen cao's voor sectoren waar ze nauwelijks leden hebben, voeren campagnes voor jongeren, zoals de FNV Young and United campagne voor afschaffıng van het minimumjeugdloon, zetten bonden op voor zzp'ers, of komen op voor de rechten van werknemers aan de onderkant van de arbeidsmarkt en voor uitkeringsgerechtigden. De substantiële representativiteit van werkgeversorganisaties en vakbonden kan dan ook als vergelijkbaar gezien worden als het gaat om hun directe doelgroepen, ook gezien de vergelijkbare positieve evaluatie door die doelgroepen van het werk van de twee (SER 2013), maar als het gaat om het algemeen belang en de maatschappij als geheel is de substantiële representativiteit hoger in het geval van de vakbonden.

Tegelijkertijd bestaan er zowel bij de werkgevers als bij de vakbonden spanningen tussen de belangen van de diverse groepen. Bij de werkgevers bestaat er traditioneel een spanning tussen de belangen van het

3 http://www.mkb.nl/over-mkb-nederland

4 http://www.awvn.nl/over-ons

5 https://www.cnv.nl/over-cnv/organisatie/missie/

6 https://www.fnv.nl/over-fnv/ons-werk/missie-en-visie/ 
grootbedrijf en het MKB, waarbij VNO-NCW regelmatig het verwijt krijgt voornamelijk voor het grootbedrijf op te komen (Braun, in deze bundel; Engelen, in deze bundel). Multinationals twijfelen juist steeds vaker of Nederlandse werkgeversorganisaties wel in staat zijn hun belangen te behartigen en of Nederlandse cao's hun internationale HRM-beleid niet in de weg staan (Verhoeff, in deze bundel). Bij de vakbonden zijn er met name in cao-onderhandelingen allereerst spanningen tussen de belangen van insiders en outsiders, oftewel tussen de groepen werknemers die over- en ondervertegenwoordigd zijn (De Beer, in deze bundel). Spanningen op het gebied van hoe belangen vertegenwoordigd moeten worden bestaan er voornamelijk tussen overleggerichte polderaars en actiegerichte organizers, iets waar we in de volgende paragraaf nog op terugkomen.

\section{Symbolische representativiteit}

Wat de symbolische representativiteit betreft zien we dat de politiek verder verwijderd lijkt van de samenleving dan werkgevers en vakbonden. Er heerst in de samenleving al jaren grote ontevredenheid met de politieke elite en er is maar een gebrekkig vertrouwen in de politieke instituties. Zowel het vertrouwen in de Tweede Kamer als in de regering is al jaren vrij laag (figuur 1.1). Hier lopen de formele en symbolische representativiteit dus sterk uiteen. Wat werkgeversorganisaties aangaat, is het onduidelijker hoe het zit met de symbolische representativiteit, omdat er geen goede data over zijn. In figuur 1.1 is bij gebrek aan beter het vertrouwen in grote ondernemingen opgenomen, en dat ligt een stuk hoger dan dat in de politieke instituties. Maar het is de vraag in hoeverre dit een proxy is voor het vertrouwen van de bevolking in werkgeversorganisaties.

Het vertrouwen in vakbonden is vergelijkbaar met dat in de grote ondernemingen en dus ook een stuk hoger dan het vertrouwen in de politieke instituties. Hier is het contrast met de beschrijvende representativiteit, oftewel de beperkte organisatiegraad, groot. Alhoewel maar een op de zes werknemers vakbondslid is, heeft 60-70 procent van de volwassen bevolking vertrouwen in diezelfde vakbonden. Dit sluit echter aan bij de bevindingen van internationaal onderzoek dat concludeert dat de daling van vakbondslidmaatschap in Europa, en in Nederland, geenszins betekent dat vakbonden geen steun hebben of dat er geen behoefte is aan de collectieve werknemersmacht die vakbonden creëren. Integendeel, surveys tonen aan dat een grote meerderheid van de bevolking, van alle leeftijdsgroepen, vindt dat werknemers de bescherming van sterke vakbonden nodig hebben (D'Art en Turner, 2008; Turner en D'Art, 2012). 
Figuur 1.1 Voldoende vertrouwen in vier instituties, bevolking van 18+, 20082015/3 (\%)

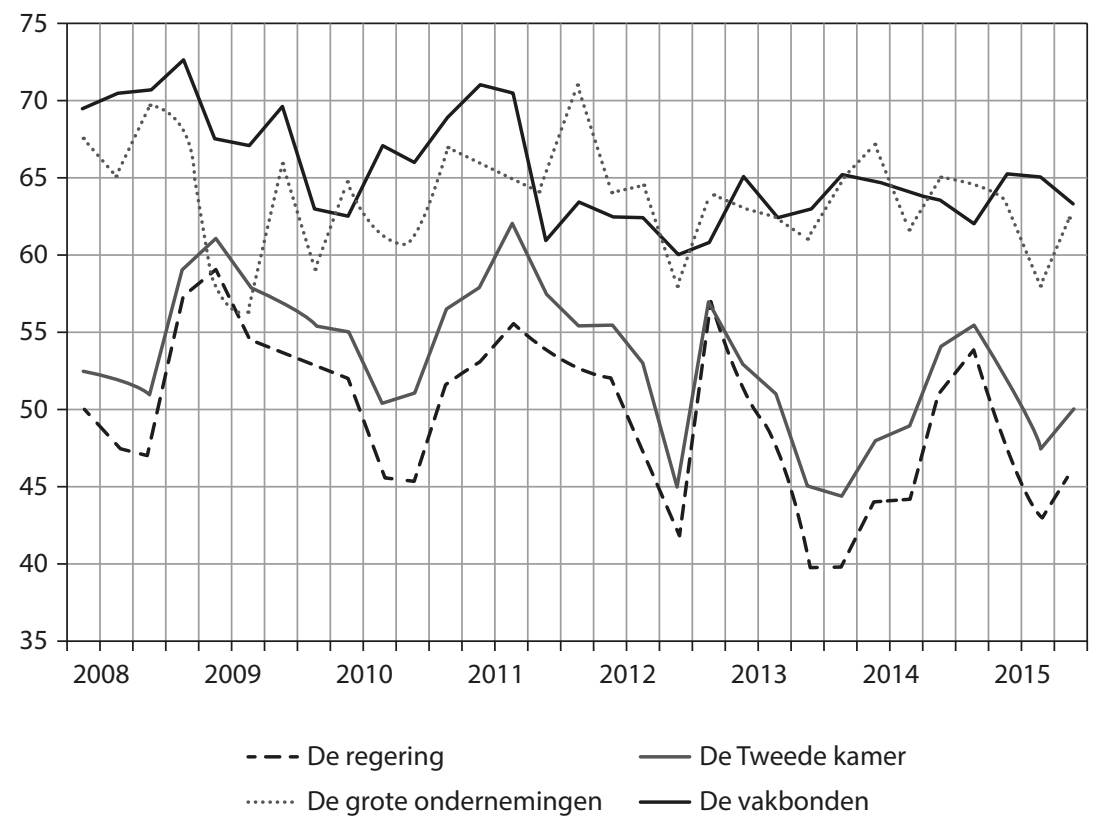

Noot: Vermeld zijn percentages scores 6-10 op een schaal van 1 (geen enkel vertrouwen) tot 10 (alle vertrouwen) in antwoord op de vraag 'Hoeveel vertrouwen heeft $u$ op dit moment in de volgende instellingen in Nederland?'

Bron: Dekker et al. 2015

Uit het bovenstaande blijkt dat het niet eenvoudig is om de inputlegitimiteit van de poldermodel-actoren eenduidig te kenschetsen. Als we de vier vormen van representativiteit als criteria nemen, hebben de actoren ieder hun sterkere en zwakkere kanten, en een hoge mate van representativiteit op de ene dimensie is geen garantie voor een hoge representativiteit op de andere dimensies. De regering heeft een sterke formele representativiteit, maar doet het beduidend minder als het gaat om de symbolische representativiteit. Werkgeversorganisaties doen het goed als het gaat om de beschrijvende en substantiële representativiteit ten opzichte van (de belangen van) hun directe doelgroep (de werkgevers), maar doen het op beide vormen van representativiteit beduidend minder als het gaat om de gehele bevolking of in termen van het algemeen belang. Dit laatste komt van de ene kant doordat werkgevers maar een heel klein deel van de bevolking vormen, en dus op geen enkele manier kunnen worden gezien als een afspiegeling hiervan. Daarnaast hebben de werkgeversorganisaties ook nauwelijks aspiraties 
om andere belangen dan die van hun directe doelgroep te behartigen, onder andere omdat zij het belang van werkgevers tot op zekere hoogte gelijkschakelen met het algemeen belang. Ze redeneren dat het goed gaat met de economie als de belangen van werkgevers goed behartigd worden en dat zich dat weer vertaalt in werk en welvaart voor de samenleving. In deze redenering wordt outputlegitimiteit dus een belangrijk criterium voor de inputlegitimiteit van de werkgeversorganisaties. Gezien de ontwikkelingen in output, zoals eerder in dit hoofdstuk besproken, is het echter de vraag of deze redenering in de praktijk voor de gehele bevolking geldt. Gezien het gebrek aan goede data is het moeilijk om duidelijke uitspraken te doen over de symbolische representativiteit van werkgeversorganisaties.

De vakbonden hebben een beperkte beschrijvende representativiteit van hun directe doelgroep, vooral door de beperkte organisatiegraad, maar in vergelijking met de werkgevers een hoge beschrijvende en substantiële representativiteit als het gaat om het algemeen belang en de maatschappij als geheel. Daarnaast genieten de vakbonden relatief veel vertrouwen in de samenleving. Het opvallendste punt hier is dat dit vertrouwen dus niet evenredig wordt uitgedrukt in lidmaatschap, maar dat lidmaatschap in Nederland wel de gebruikelijke maatstaf is om de representativiteit van vakbonden te beoordelen. Vanuit onderzoek komen een aantal redenen naar voren voor deze discrepantie tussen de twee vormen van representativiteit, waaronder free rider-gedrag (als werknemer wel profiteren van de activiteiten van vakbonden en met name de cao's die ze afspreken, maar geen lid worden en contributie betalen), het als vanzelf ervaren dat zaken als een cao bestaan (44 procent van de volwassen Nederlanders geeft aan simpelweg nooit serieus nagedacht te hebben of ze wel of niet lid zouden worden), of het feit dat we tegenwoordig simpelweg minder makkelijk lid worden van organisaties (SER, 2013). Dit roept de vraag op of lidmaatschap wel het juiste criterium is om de representativiteit en dus de inputlegitimiteit van vakbonden uit te drukken, en wat de alternatieven hiervoor zijn, zoals legitimiteit gebaseerd op vakbondsverkiezingen zoals in Frankrijk het gebruik is, of stemmen over cao-onderhandelingsresultaten door leden en niet-leden van vakbonden, etc. (Jaspers en Baltussen, 2011).

Gebrek aan inputlegitimiteit van de actoren van het poldermodel ondermijnt de legitimiteit van het poldermodel zelf en van onderdelen ervan zoals het cao-stelsel. Vanuit dit perspectief hangt de toekomstige stabiliteit van het poldermodel af van een versterking van de legitimiteit van de drie actoren, en met name van een herstel van het vertrouwen tussen politieke instituties en de bevolking, een groei van de organisatiegraad van vakbonden gecombineerd met alternatieve criteria om de legitimiteit van 
vakbonden te bepalen, en een bredere opvatting van en gerichtheid op het algemeen belang van de kant van werkgevers.

\section{Proceslegitimiteit}

Proceslegitimiteit betreft de kwaliteit van de governance van het poldermodel in termen van transparantie en efficiency van processen, en onderling vertrouwen en samenwerking tussen de actoren (Schmidt, 2013). Naast input- en outputlegitimiteit is ook proceslegitimiteit een belangrijke factor om de legitimiteit van het poldermodel te evalueren, en het is bovendien een prominent thema in het publieke debat.

Een belangrijk kritiekpunt op het poldermodel is dat het niet transparant is en vol zit met achterkamertjespolitiek, waarin de leiders van de vakbonden, werkgeversorganisaties en regering afspraken maken en akkoorden sluiten zonder dat hun eigen achterban of het brede publiek zicht heeft op het proces of zeggenschap over de uitkomst. Dit soort besluitvormingsstructuur kan efficiënt zijn omdat ze bijdraagt aan onderling vertrouwen onder de beleidselite, en het mogelijk maakt om beleidsposities inhoudelijk bij te stellen tijdens het overleg zonder dit steeds uit te hoeven leggen aan achterban of media (Braun, in deze bundel). Maar het gebrek aan transparantie leidt tevens tot twijfels bij achterbannen en publieke opinie over welke belangen er precies zijn uitgeruild in de compromissen die bereikt worden. En intern draagvlak voor het onderhandelingsresultaat is er niet automatisch. Dat bleek in 2011 toen de toenmalige voorzitter Jongerius van de FNV tegen de zin van de twee grootste bonden binnen de FNV het pensioenakkoord tekende met overheid en werkgevers. De interne oppositie en afwijzing van het akkoord door een groot deel van de achterban leidde tot de val van Jongerius, het einde van het pensioenakkoord en uiteindelijk tot het uiteenvallen, en heroprichten in nieuwe vorm, van de FNV. In het vormgeven van de nieuwe FNV was een meer democratische interne structuur een van de hoofddoelen, resulterend in het installeren van een ledenparlement, dat nu de koers van de bond bepaalt en het bestuur controleert. Dit lijkt goed te passen in een al in gang gezette tendens tot meer transparantie, die vooral voortkomt uit het feit dat de (sociale) media de polderactoren tot steeds meer openheid dwingen en ze steeds meer in een 'glazen huis' dan in een 'black box' opereren (Boonstra, in deze bundel).

Verhoogde transparantie kan verregaande consequenties hebben voor de vorm waarin er binnen de polder in de toekomst onderhandeld gaat worden. Het lijkt onvermijdelijk dat dit een lager achterkamertjesgehalte gaat hebben, 
inclusief een beperktere manoeuvreerruimte voor de onderhandelaars en een grotere druk om resultaten te verantwoorden. Transparantie en meer invloed van de diverse achterbannen kan dus ten koste van de efficiency van het proces gaan, het moeilijker maken tot overeenstemming te komen en tot scherpere standpunten en meer conflict leiden. Het kan ook leiden tot een kleinere afstand en betere interactie tussen vertegenwoordigers en vertegenwoordigden, meer invloed van leden op de onderhandelingen (bijvoorbeeld via zo'n ledenparlement), en dus tot meer draagvlak voor de onderhandelingsuitkomsten.

Naast transparantie is vertrouwen een belangrijk element in het poldermodel. Vertrouwen is belangrijk om met elkaar aan de onderhandelingstafel te willen gaan zitten, om bereid te zijn het eigenbelang gedeeltelijk op te geven en om afspraken te kunnen maken die niet extreem gedetailleerd en juridisch dichtgetimmerd zijn, maar gaandeweg ingevuld worden. Sinds 'Wassenaar' is er heel wat vertrouwen opgebouwd tussen de vakbonden, werkgeversorganisaties en overheid, uitgedrukt in een groot aantal sociale akkoorden, cao's en andersoortige formele en informele interactie. De actoren kennen elkaar en elkaars problemen en voorkeuren goed en zijn over het algemeen zeer bereid tot samenwerking en compromissen. Een uitdrukking hiervan is het zeer lage stakingspercentage dat Nederland al jaren kenmerkt.

De laatste jaren is vertrouwen echter geen gegeven meer, ondanks het feit dat er nog steeds veel samengewerkt wordt binnen de polderinstituties. Sinds de recente financieel-economische crisis lijken bonden en werkgevers op meer gespannen voet te staan, vooral als het om de cao's gaat. Vanuit werkgeverskringen worden vakbonden, en voornamelijk de FNV, verweten te weinig aandacht te hebben voor de moeilijke economische omstandigheden en vooral op zichzelf gericht te zijn (Verhoeff, in deze bundel). Ze krijgen de kritiek dat ze niet met de tijd mee willen gaan, vasthouden aan oude verworvenheden in de cao (zoals extra vrije dagen voor oudere werknemers of leeftijdsgebonden beloning) en onverantwoorde looneisen stellen in economisch moeilijke tijden. De werkgevers hebben ook veel moeite met de groeiende interesse bij de FNV in organizing, dat wordt gezien als strijdig met de traditionele overlegcultuur van het poldermodel (ibid.). Ze vinden dan ook dat de FNV zich steeds meer buiten de polder plaatst en geven geregeld aan dat ze het vertrouwen in de bond aan het verliezen zijn.

Het vertrouwen van de vakbonden in de werkgevers is ook niet op het hoogtepunt. Ze vinden dat werkgevers steeds meer het ondernemersrisico afschuiven op de werknemers, voornamelijk in de vorm van te veel loonmatiging en excessief gebruik van flexibele contracten en schijnzelfstandigheid 
(Boonstra, in deze bundel). Daarnaast zien de vakbonden dat een deel van de werkgevers steeds nieuwe vormen van arbeidsrelaties in het leven roept, die leiden tot een verder fragmentering van de arbeidsmarkt en de groei van laagwaardige werkgelegenheid, zoals payrollen, contracting of detacheringsconstructies (ibid.). Ook zien ze dat de druk van opdrachtgevers op bijvoorbeeld schoonmaakbedrijven of van aanbestedingsprocedures op mogelijke uitvoerders leidt tot oneigenlijke druk op arbeidsvoorwaarden en arbeidsomstandigheden. Ze vinden dat (sommige) werkgevers met deze praktijken de geest van de polder niet nakomen en vooral nemen en niet geven. En als bijvoorbeeld in het sociaal akkoord van 2013 wordt afgesproken dat de doorgeslagen flexibilisering moet worden aangepakt, dan zien de vakbonden werkgevers weinig of geen spontaan gevolg geven aan deze afspraken, wat het vertrouwen ondermijnt.

Een van de gevolgen van het dalende wederzijdse vertrouwen is dat het in de afgelopen jaren (2013-2015) vaak erg veel moeite kost voor bonden en werkgevers om cao's te vernieuwen. Zo hebben bonden en werkgevers in de bouw pas na 1,5 jaar onderhandelen mid-2015 de bouw-cao kunnen vernieuwen. En een aantal recente cao's zijn door de werkgevers afgesloten zonder de FNV, de grootste vakbond, maar met de CNV en kleinere bonden, bijvoorbeeld de cao voor rijksambtenaren en de cao voor supermarkten. Gebrekkig vertrouwen ondermijnt dan ook het functioneren van het caostelsel, een van de pijlers van het poldermodel.

De proceslegitimiteit van het poldermodel staat dus onder druk. De roep om meer transparantie en daarmee meer accountability van elite naar achterban lijkt langzaam maar zeker gehoor te vinden, maar het is nog onduidelijk of dit ten koste zal gaan van de efficiency en capaciteit om tot compromissen te komen, en of het zal leiden tot meer conflict. Wat het vertrouwen tussen werkgevers en vakbonden betreft, hoewel dit vooralsnog op een behoorlijk peil lijkt te zijn, wijzen de recente ontwikkelingen duidelijk op een verslechtering. Mocht deze trend doorzetten, dan wordt een van de noodzakelijke voorwaarden voor het functioneren van het poldermodel aangetast.

\section{Conclusie}

Is het poldermodel stervende of springlevend? Vanuit het perspectief van de drie vormen van legitimiteit die de basis voor de analyse in deze inleiding vormen, is het poldermodel in 2016 geen mirakel meer en heeft het naast een aantal sterke punten ook een aantal serieuze gebreken. Wat de 
outputlegitimiteit betreft presteert het nog goed, hoewel niet meer uitzonderlijk, op het gebied van de werkgelegenheidsgraad, groei en sociale vrede, maar veel minder goed als het gaat om de kwaliteit van werk, het creëren van additionele uren werk, productiviteit, ongelijkheid, private schulden of innovatie. Alle drie de partijen in het poldermodel hebben ook hun eigen sterke en zwakke kanten wat betreft de inputlegitimiteit. De regering en Kamer genieten een hoge formele legitimiteit, maar hebben maar beperkt het vertrouwen van de bevolking. Vakbonden genieten beduidend meer vertrouwen van de bevolking en hebben een relatief sterke oriëntatie op het algemeen belang, maar ze zien hun organisatiegraad al lange tijd dalen, en worstelen geregeld met de insider-outsider vraag. Werkgeversorganisaties hebben een hoge organisatiegraad, maar weten niet altijd zowel de belangen van zowel het grootbedrijf als het kleinbedrijf even goed te behartigen, en lijken maar beperkt in staat om naast het eigenbelang ook het algemeen belang te vertegenwoordigen. In het geval van de proceslegitimiteit zijn twee problematische factoren geïdentificeerd. Een is de gebrekkige transparantie en de moeilijke vraag hoe transparantie te verbeteren zonder de effectiviteit van het proces te ondergraven. De ander is het verslechterende vertrouwen tussen werkgevers en vakbonden.

Als deze ontwikkelingen doorzetten, dan zal het bestaansrecht van het poldermodel steeds meer onder druk komen te staan. Daarnaast is de ruimte voor nationaal beleid sowieso kleiner aan het worden met de opmars van de EU. Een van de conclusies die hieruit getrokken zou kunnen worden is dat het poldermodel zijn beste tijd heeft gehad en dat het moet worden ontmanteld. Maar dit roept de vraag op wat dan het alternatief is. Wat sociaaleconomisch beleid betreft zou dat op korte termijn betekenen dat het primaat geheel bij de politiek wordt gelegd. Het valt echter zeer te betwijfelen of dat zou leiden tot verbeteringen in de output- of inputlegitimiteit, gezien het beperkte vertrouwen dat de politieke instituties genieten en het feit dat de recente regeringen de polder juist vaak nodig hebben gehad om het draagvlak voor hun beleid op te krikken. Op het gebied van arbeidsvoorwaardenvorming zou het betekenen dat de rol van de cao drastisch zou worden verkleind, met als gevolg een verslechtering van de positie van de zwakste en minst georganiseerde werknemers en een snel toenemende ongelijkheid en sociale onrust. Dit lijkt een weinig aantrekkelijke weg.

Een alternatieve conclusie kan zijn dat het huidige functioneren van het poldermodel nog niet zo slecht is, gezien de veranderende omstandigheden en de behaalde resultaten, en dat kleine aanpassingen zoals het recente opnemen van vertegenwoordigers van bijvoorbeeld zzp'ers in de SER voldoende zijn om de relevantie van het model te garanderen. Dit kan 
echter ook gezien worden als 'institutioneel doormodderen', en als een te grote invloed van pad-afhankelijkheid en institutioneel determinisme op beleidsbeslissingen (Engelen, in deze bundel), waar werkelijk beleidsleren en meer diepgaande verandering vereist is.

Een derde, en meest logische conclusie is dat de capaciteit van het poldermodel niet (meer) in de pas loopt met ontwikkelingen in economie, arbeidsmarkt en politiek, en aan serieuze vernieuwing toe is. Uit de analyse in dit hoofdstuk volgen een aantal mogelijkheden om de input-, output- en proceslegitimiteit van het poldermodel versterken, die we hier kort aanstippen. Allereerst is het discursieve fundament en daarmee ook het traditionele beleidspakket van het poldermodel nodig aan vernieuwing toe. De traditionele storyline dat een internationaal concurrerend bedrijfsleven gestimuleerd door loonmatiging het recept is voor een goed functionerende economie en arbeidsmarkt, voldoet niet meer. Om de outputlegitimiteit te verhogen is er meer aandacht nodig voor het stimuleren van de binnenlandse consumptie, voor het terugdraaien van de groeiende ongelijkheid en voor het aanpakken van de private schulden en de kwetsbaarheid voor schokken in het internationale financiële systeem. Ook zou er in overheidsbeleid, cao's en op organisatieniveau meer prioriteit gegeven moeten worden aan het verhogen van baankwaliteit, productiviteit en innovatie.

De vakbonden en werkgeversorganisaties hebben een belangrijke gezamenlijke rol te spelen in zo'n heroriëntatie van beleid. Hiervoor is het wel een vereiste dat er voldoende vertrouwen tussen hen bestaat. In de afgelopen jaren is dit vertrouwen echter gedaald en hebben vakbonden en werkgevers veel tijd en energie verloren met onderhandelingen en conflicten over, onder andere, de onderkant van de arbeidsmarkt, flexibilisering, het gebruik van zzp'ers, schijnconstructies, arbeidsmigranten, leeftijdsgebonden caobepalingen, etc. Om dit vertrouwen, en daarmee de proceslegitimiteit van het poldermodel, weer te versterken en de sociale partners ruimte te geven om gezamenlijk aan upgrading te werken, zou de overheid meer duidelijkheid kunnen scheppen over wat wel en niet mogelijk is, bijvoorbeeld door in de wetgeving duidelijk vast te leggen wanneer flexibele contracten wel en niet gepast zijn, wat minimumtarieven voor zzp'ers zijn, welke vormen van arbeidsrelaties wel en niet acceptabel zijn, etc. Door zo meer duidelijkheid te scheppen, ondersteund door een versterkte arbeidsinspectie, zou er meer rust in de arbeidsverhoudingen kunnen worden gecreëerd, en meer ruimte voor verbeteringen van baankwaliteit, productiviteit en innovatie. Zoals Visser en Hemerijck twintig jaar geleden al concludeerden: voor een krachtig corporatisme is een krachtige overheid nodig. 
En wat de inputlegitimiteit van het poldermodel betreft, zowel de overheid als bonden en werkgeversorganisaties zullen hun positie hier moeten versterken. De overheid zal het vertrouwen van de bevolking terug moeten winnen, maar de vraag hoe ze dit kan doen valt buiten het bereik van deze inleiding. Vakbonden genieten juist een behoorlijk groot vertrouwen van de bevolking, maar zien toch hun organisatiegraad dalen, wat hun inputlegitimiteit ondergraaft. Het verkrijgen van meer leden is al enige tijd een prioriteit voor de bonden, maar is erg moeilijk gebleken. Deze tegenstelling tussen vertrouwen en lidmaatschap zou aangegrepen kunnen worden om te zoeken naar andere vormen dan lidmaatschap om de representativiteit van vakbonden te bepalen, bijvoorbeeld via verkiezingen. Vakbonden zullen ook nog duidelijker op moeten komen voor de belangen van de outsiders op de arbeidsmarkt om insider-outsider-tegenstellingen te vermijden en hun brede oriëntatie te verwezenlijken.

En ook werkgevers en hun organisaties zullen een beter evenwicht moeten vinden, maar dan tussen het behartigen van de belangen van grote en kleine ondernemingen. Daarnaast zullen ze zich vooral meer moeten gaan richten op het algemeen belang en niet alleen hun eigen belang. Of, zoals Harry van de Kraats, algemeen directeur van de AWVN, onlangs aangaf, ondernemingen zijn er niet alleen om shareholdervalue te creëren en winst te maken, ze moeten ook een maatschappelijke rol spelen en bijdragen aan sociaal welzijn, duurzaamheid en eerlijke beloning.?

Het tot stand brengen van dit soort veranderingen is een uitdaging en zal niet makkelijk zijn. Het vereist zelfreflectie van actoren, en moeilijke processen van afstemming en onderhandeling om een nieuwe consensus over de fundamenten en het functioneren van het poldermodel te bereiken. En daarnaast, zoals Visser en Hemerijck in 1997 al aangaven, is er ook enige fortuna nodig. 


\title{
2 Het Nederlandse poldermodel langs de democratische meetlat
}

\author{
Over representativiteit, verantwoording en \\ belangenvertegenwoordiging
}

\section{Caelesta Braun}

Een van de hoekstenen van het poldermodel is de duurzame beleidsbetrokkenheid van belangenorganisaties, in het bijzonder de sociale partners. Op gezette tijden in het politieke besluitvormingsproces schuiven de belangrijkste werkgevers- en werknemersorganisaties al dan niet met de overheid aan tafel aan om te onderhandelen over sociaaleconomische beleidskwesties. Ons poldermodel, ofwel het Nederlandse mirakel, zoals het door Visser en Hemerijck (1997) is gekarakteriseerd, heeft de afgelopen decennia met wisselend succes de Nederlandse economie weten aan te zwengelen en op gang kunnen houden. Hoe het publiek en de politiek het poldermodel beoordelen, gaat meestal over de geleverde prestaties, met andere woorden of het poldermodel tot een betere en duurzamere economie leidt dan andere modellen. Het onderhandelingsproces met sociale partners wordt daarbij vaak gezien als middel tot het bereiken van een economisch doel. De beroemde crisisretoriek van premier Lubbers: 'Nederland is ziek', om zo de sociale partners te bewegen om de tafel te gaan en tot een gezamenlijke oplossing te komen, is een bekend voorbeeld hiervan (Kuipers, 2005, Visser en Hemerijck, 1997).

Deze focus op de uitkomsten van het poldermodel laat de inrichting van de onderhandelingsprocessen - wie neemt deel, om welke redenen, met welke standpunten, en hoe vindt dit proces plaats - onderbelicht. De nadruk op deze zogenaamde output legitimacy (Schmidt, 2013) is opvallend, omdat veel van de fricties vaak betrekking hebben op het proces en de betrokken actoren. Interne organisatorische strubbelingen binnen de sociale partners, zoals de lage lidmaatschapscijfers van de vakbonden en de recente richtingenstrijd zowel binnen FNV als MKB Nederland, roepen bijvoorbeeld twijfels op over de inrichting van het poldermodel en niet zozeer over de uitkomsten ervan. Het absolute ledenaantal van de drie grote vakbondskoepels in Nederland: Federatie Nederlandse Vakvereniging (FNV), Christelijk Nationaal Vakverbond (CNV) en de Vakcentrale voor Professionals (VCP) nemen bijvoorbeeld sinds 2000 gestaag af (SCP, 2014). 
Het gros van deze afnemende achterban is van middelbare leeftijd en heeft een vast arbeidscontract (SCP, 2014; zie ook Visser, 2007). De jongere werknemers zijn meestal geen lid omdat die zich niet aangesproken voelen door deze oude, brede vakbewegingen. Niet alleen de vakbonden worstelen met interne fricties. Ook de werkgeversorganisaties hebben moeite de gelederen te sluiten. De in september 2013 teruggetreden voorzitter van MKB Nederland richtte in diezelfde maand een nieuwe beweging op van en voor Ondernemend Nederland (ONL) uit onvrede met de koers van MKB Nederland. ${ }^{1}$

Deze voorbeelden illustreren dat het goed functioneren van het poldermodel niet alleen een kwestie is van effectiviteit, maar dat het proces en de interactie tussen de verschillende actoren ook een belangrijke rol spelen bij het 'Nederlandse mirakel', wat ook wel input en throughput legitimacy genoemd wordt (Schmidt, 2013; Scharpf, 1999). Input legitimacy gaat over de mate waarin politiek-bestuurlijke instituties politieke participatie, zoals stemmen, door burgers stimuleren. Throughput legitimacy richt zich op aspecten die te maken hebben met de inrichting van het besluitvormingsproces, bijvoorbeeld verantwoordingsmechanismen, transparantie en het betrekken van burgers bij het besluitvormingsproces door met ze in overleg te gaan. Het is gebaseerd op de kwaliteit van interacties tussen actoren in het besluitvormingsproces (Schmidt, 2013, p. 5). De input legitimacy van het poldermodel heeft daarmee betrekking op wie er aan de onderhandelingstafel aanschuiven en op basis van welke criteria. De throughput legitimacy van het poldermodel heeft betrekking op hoe het onderhandelingsproces met sociale partners en het maatschappelijk middenveld is vormgegeven. Bij deze twee aspecten staan vragen centraal zoals welke belangen door de sociale partners vertegenwoordigd worden, welke belangen ze zouden moeten vertegenwoordigen en waarom dat wel of niet plaatsvindt.

Deze vragen zijn uiterst relevant, omdat ze de kern van het poldermodel raken. Een van de belangrijkste pijlers waarop het poldermodel gebaseerd is, is namelijk de notie dat de sociale partners die aanschuiven aan de onderhandelingstafel representatieve belangenbehartigers zijn van niet alleen hun eigen achterban, maarvan een breed palet aan sociaaleconomische belangen. Of dit daadwerkelijk zo is, vergt een analyse van de verschillende soorten en mate(n) van representativiteit en verantwoordingsmechanismen.

Op basis van de literatuur over verschillende soorten representativiteit, democratie en bijbehorende verantwoordingsmechanismen formuleer ik een evaluatie-instrument, de democratische meetlat, om het democratisch 
gehalte van het poldermodel te analyseren. Dit levert een aantal inzichten op. Ten eerste: het gaat bij een analyse van het democratisch gehalte van het poldermodel niet alleen om beleidsuitkomsten en effectiviteit. De daadwerkelijke participatie van sociaaleconomische belangenorganisaties, een adequate vertegenwoordiging daarvan door de sociale partners, én het tegenwicht dat de overheid kan en wil bieden aan dit spel van belangen, wegen allemaal mee.

Ten tweede: een antwoord op de vraag of het poldermodel democratisch zou moeten zijn, is een kwestie van where you stand, depends on where you sit. Als je het poldermodel ziet als middel tot een economisch doel (de eerdergenoemde output legitimacy), dan is de inrichting van het proces minder relevant en tellen alleen de uitkomsten in het licht van economische stabiliteit en groei. Een visie op het democratisch gehalte van het proces (de input en throughput legitimacy) hangt af van het gekozen democratische perspectief. Aanhangers van participatieve democratie, waar de nadruk ligt op Schmidts input legitimacy, zullen het poldermodel als relatief ondemocratisch beoordelen omdat de mogelijkheden voor participatie van verschillende belangenorganisaties beperkt zijn. Voorstanders van deliberatieve democratie, waarbij de kwaliteit van de argumenten en redeneringen voorop staat, zullen daar minder waarde aan hechten en het poldermodel als democratischer beoordelen. Aanhangers van de representatieve democratie, tot slot, zullen zich richten op de mate waarin de sociale partners alle sociaaleconomische belangen adequaat vertegenwoordigen, en daarmee ook met gemengde gevoelens het democratisch gehalte van het poldermodel bekijken. Als het proces voorop staat in een evaluatie van het poldermodel, en gegeven dat het representativiteitsbeginsel een van de hoekstenen van het poldermodel is, dan is het democratisch gehalte van het poldermodel voor verbetering vatbaar.

\section{Het poldermodel en representativiteit}

Een van de hoekstenen van het poldermodel is het beginsel van representativiteit gekoppeld aan het mede dragen van publieke verantwoordelijkheden door de grote (koepels van) belangenorganisaties, oftewel de sociale partners, zoals in de nationale beleidsoverleggen van de Sociaal-Economische Raad (SER), Stichting van de Arbeid (StvdA) en Voor- en Najaarsoverleggen. ${ }^{2}$

2 In dit hoofdstuk worden de termen sociale partners, belangenorganisaties en maatschappelijk middenveld afwisselend gebruikt. Met sociale partners worden de koepels van 
Van deze koepelorganisaties wordt verwacht dat zij namens hun achterban spreken en dat zij op basis van deze representativiteit de verantwoordelijkheid willen en kunnen nemen voor de uitvoering van publieke besluiten die verder reiken dan hun eigen achterban (Hemerijck, 1994; Visser en Hemerijck, 1997). Dit grondbeginsel van het poldermodel veronderstelt twee principes. Ten eerste wordt verwacht dat deze organisaties in staat zijn om alle sociaaleconomische belangen te vertegenwoordigen, juist omdat ze medeverantwoordelijkheid dragen voor besluiten die verder reiken dan hun eigen achterban. Ten tweede wordt verondersteld dat ze op een adequate manier hun eigen achterban vertegenwoordigen. Met andere woorden, dit veronderstelt zowel adequate belangenaggregatie (alle relevante sociaaleconomische belangen zijn zichtbaar) en belangenarticulatie (een goede vertaalslag van de belangen van de eigen achterban naar een gezamenlijk in te brengen standpunt).

Het antwoord op de vraag of een goede belangenarticulatie en belangenaggregatie daadwerkelijk plaatsvinden, kunnen we met behulp van theorieën over de democratie inzichtelijk maken. Vanuit deze theorie zijn hierbij twee kernbegrippen van belang: representativiteit en democratische verantwoording. Democratie en representatie zijn in onze tijd onlosmakelijk met elkaar verbonden, maar dat is lang niet altijd zo geweest. Democratie betekent, teruggaand tot de Griekse etymologische wortels ervan, regering door het volk. Democratie in deze Griekse variant veronderstelde directe betrokkenheid bij het bestuur door een select gezelschap - vrouwen en nietGrieken ('barbaren') werden incapabel geacht om te besturen. Dus eigenlijk had de klassieke Griekse democratie niets te maken met representatie of vertegenwoordiging, er was alleen sprake van directe betrokkenheid bij politieke besluitvorming van een aantal burgers en uitsluiting van de rest. Representatie heeft op haar beurt oorspronkelijk niets te maken met betrokkenheid van burgers bij politieke besluitvorming. Het was een manier om in monarchieën en keizerrijken afgezanten van de verre uithoeken van het rijk tot zich te roepen om belasting te innen of om oproer te voorkomen,

werkgevers- en werknemersorganisaties bedoeld, die structureel aanschuiven bij de Voor- en Najaarsoverleggen en in de context van de SER: werkgeversorganisaties VNO-NCW, MKB Nederland en LTO, en de drie grote vakbondskoepels FNV, CNV en VCP (voorheen MHP). Met belangenorganisaties worden, naast deze klassieke sociale partners, de organisaties aangeduid die een sociaal(economisch) belang behartigen. Hieronder vallen de brancheorganisaties, maar ook de consumentenorganisaties, de sportkoepels, de natuur- en milieuorganisaties en de organisaties voor goede doelen. Gezamenlijk vormen deze belangenorganisaties het maatschappelijk middenveld. 
en had niets te maken met het streven om de individuele burgers bij de politieke besluitvorming te betrekken (Pitkin, 2004).

Toen het idee van democratie veel later weer ten tonele kwam, werd het toegepast op de natiestaat in plaats van op stadstaten zoals in het klassieke Griekenland. En deze schaalvergroting leek de pure en directe vorm van Griekse democratische traditie onmogelijk te maken. Daarmee werd de relatie met representatie heel logisch. Volgens Pitkin (2004, p. 337-338): '[if we] extend the suffrage, democracy will be enabled by representation. Since (...) the room will not hold all, the people would rule themselves vicariously, through their representatives.' Representatie werd het vehikel om de democratie te laten functioneren binnen de context van de natiestaat, en langzamerhand vormen de twee een onlosmakelijk duo. Maar wat betekent representatie nu daadwerkelijk en welke verantwoordingsmechanismen zijn relevant als we het hebben over het democratisch gehalte van het poldermodel?

\section{Soorten en mate(n) van representativiteit}

Representativiteit is een complex begrip en behelst een paradox. In de meest algemene zin betekent het dat iets of iemand die niet fysiek aanwezig is, toch op een bepaalde manier aanwezig is. Representeren is volgens Pitkin, een van de bekendste politiek-theoretische denkers op dit gebied, 'acting in the interest of the represented, in a manner responsive to them' (1967, p. 209; 306). De vraag of en hoe dit proces plaatsvindt, is tweeledig: hoe kan iets of iemand in niet letterlijke zin toch aanwezig zijn (met andere woorden, welke vormen van representativiteit zijn er?) en, ten tweede, hoe kan responsiviteit tussen vertegenwoordiger en vertegenwoordigde tot uiting komen (met andere woorden, welke verantwoordingsmechanismen zijn er?). Representativiteit behelst dus zowel een vergelijking met als een bepaalde mate van interactie tussen vertegenwoordiger en vertegenwoordigde.

In de literatuur zijn een aantal vormen van representativiteit te onderscheiden, die vrijwel allemaal teruggevoerd kunnen worden op het baanbrekende boek van Pitkin (1967) The Concept of Representation. Pitkin onderscheidt vier afzonderlijke, maar onderling verbonden betekenissen van het begrip representatie. Ten eerste formele representatie, waarbij het gaat om de institutionele regels en procedures op basis waarvan vertegenwoordigers worden gekozen. Verschillende verantwoordingsmechanismen zijn hierbij van belang, op basis waarvan de vertegenwoordigden de vertegenwoordiger verantwoordelijk kunnen houden. Dit kan zowel achteraf als vooraf, door het verstrekken van een mandaat. Voor het poldermodel zijn 
dan niet alleen de relaties met sociale partners en democratisch gekozen vertegenwoordigers van belang, maar ook binnen de grote koepelorganisaties de interne procedures om een bestuur of vertegenwoordigers te kiezen dan wel te benoemen, en welk mandaat deze vertegenwoordigers hebben. Veel koepelorganisaties hebben interne procedures om de betrokkenheid van hun leden hierbij te garanderen.

Een tweede betekenis van representatie volgens Pitkin is beschrijvende representatie. Bij beschrijvende representatie gaat het om de gelijkenis tussen bepaalde kenmerken van de vertegenwoordiger en vertegenwoordigden. Functionele vertegenwoordiging gaat bijvoorbeeld om gelijkenis in termen van beroepsbeoefening, bij sociale vertegenwoordiging gaat het om kenmerken zoals geslacht, klasse of etniciteit. In het poldermodel komt dit beschrijvende aspect ook vaak aan bod. Om een goede vertegenwoordiging van de belangen van de zzp'ers te garanderen, worden recent opgerichte belangenorganisaties van zzp'ers aan de onderhandelingstafel uitgenodigd. Hierbij wordt ervan uitgegaan dat het belangrijk is om de 'beroepsgroep' van de zzp'ers ook zelf vertegenwoordigd te hebben. De assumptie die hieraan ten grondslag ligt, is dat beschrijvende representatie een noodzakelijke voorwaarde is voor representatie in de derde betekenis van het woord, namelijk substantiële representativiteit.

Bij substantiële representativiteit gaat het namelijk om de overeenkomst tussen de handelingen van de vertegenwoordiger en de belangen van de vertegenwoordigde. Terugkomend op het voorbeeld van de belangenorganisaties van zpp'ers, is het in de context van substantiële representativiteit van belang of deze organisaties daadwerkelijk beter in staat zijn en meer geneigd zijn om de beleidsvoorkeuren van de zpp'ers in te brengen in het beleidsproces dan de meer algemene vakbonden of werkgeversorganisaties. Daarbij overstijgt de substantiële representativiteit de meer beschrijvende vorm, die alleen een gelijkenis veronderstelt. Bij substantiële representatie is het uitgangspunt dat door de gelijkenis er ook de capaciteit is om daadwerkelijk op te komen voor de belangen van een specifieke achterban.

De vierde betekenis van representatie, tot slot, is symbolische vertegenwoordiging. Hierbij gaat het erom of de vertegenwoordigden zich op een effectieve en faire manier vertegenwoordigd voelen. Het gaat hierbij dus meer om de perceptie van de achterban of het maatschappelijk middenveld in algemene zin en in hoeverre zij zich vertegenwoordigd voelen, dan dat ze daadwerkelijk vertegenwoordigd zijn. In de context van het poldermodel zie je deze symbolische dimensie vooral terug in veel van de publieke acties van sociale partners, in het bijzonder stakingen van vakbonden. Alhoewel stakingen vaak als een laatste drukmiddel in het onderhandelingsproces 
worden gezien, zijn ze ook bedoeld om het moreel van de individuele werknemers hoog te houden, zodat zij zich vertegenwoordigd weten door hun vakbonden. De stakingen en protestacties op het Plein of het Malieveld in Den Haag komen vaak als het betreffende wetsvoorstel in de Tweede Kamer behandeld wordt en dat is op een zeer laat moment in het wetgevingsproces. Als invloedsmiddel is het dan een poging om via een meerderheid in de Tweede Kamer de regering toch nog op de knieën te dwingen. Maar daarbij is het ook zeer zeker bedoeld om de werknemers binnen de branche een hart onder te riem te steken door via gezamenlijke deelname aan de stakingsacties het collectief gevoel aan te wakkeren en publiekelijk het beeld te geven dat er flinke politieke druk wordt uitgeoefend.

Bovenstaande verschillende dimensies van representativiteit komen in verschillende mate terug in het poldermodel. Daar waar de sociale akkoorden nog steeds overwegend tot stand komen door onderhandelingen tussen de gevestigde vakbonden en werkgevers, zien we bijvoorbeeld dat in recente jaren voormalige outsiders steeds meer moeite doen om op sociaaleconomische terreinen deel te mogen nemen aan de onderhandelingen. Het ontstaan van belangenorganisaties van zpp'ers is hier een voorbeeld van, evenals de oprichting van jongerenafdelingen binnen de bestaande sociale partners, met name de vakbonden. En alhoewel de leden van de SER nog vrijwel alleen afkomstig zijn van de klassieke sociale partners, zoals VNO-NCW, MKB, LTO, FNV en CNV, zijn individuele lidorganisaties van deze grote koepels, zoals werkgeversorganisatie Bouwend Nederland, of andere belangenorganisaties, zoals de Consumentenbond en Natuurmonumenten, als (adviserend) lid betrokken bij de verschillende commissies van de SER. Hier zien we vooral de combinatie van substantiële en beschrijvende representativiteit. Voor dossiers die een groot sociaaleconomisch vraagstuk behandelen, worden organisaties die andere of meer specifieke sociaaleconomische belangen vertegenwoordigen uitgenodigd om deel te nemen aan de overleggen. De veronderstelling is dan dat daarmee aan de vertegenwoordiging van deze specifieke belangen meer recht wordt gedaan. Een van de opvallendste voorbeelden hiervan is de totstandkoming van het Energieakkoord in 2013 waar met meer dan veertig partners onderhandelingen werden gevoerd en waar de milieubeweging een sterke machtsfactor bleek (Mommers et al., 2013).

We zien dus dat recent steeds vaker de nadruk ligt op de veronderstelde relatie tussen beschrijvende en substantiële representativiteit. De aanname is dan dat als we er zorg voor dragen dat de verschillende belangen getalsmatig adequaat vertegenwoordigd zijn, dat ertoe zal leiden dat ook deze veelvoud aan belangen aan bod komt in de uiteindelijke akkoorden of 
besluiten. Of de getalsmatige overeenkomst zich ook daadwerkelijk vertaalt in de behartiging van de verschillende sociaaleconomische belangen hangt met name af van verschillende verantwoordingsmechanismen.

\section{Verantwoording in het Nederlandse poldermodel}

De relatie tussen de beschrijvende en substantiële dimensies van representativiteit is geen vanzelfsprekendheid. Om de vertaalslag hiertussen goed te kunnen beoordelen is de formele dimensie van representativiteit van belang, namelijk de verschillende vertegenwoordigingsmechanismen die ervoor zorgen dat de relatie tussen vertegenwoordiger en vertegenwoordigde gewaarborgd is. Daarbij gaat het vooral over hoe het poldermodel ingebed is in onze democratische rechtsstaat.

Democratie is er in allerlei soorten en maten. Vaak grijpt men vaak terug naar de beroemde uitspraak van Abraham Lincoln: 'government of the people, for the people, by the people ${ }^{33}$ en worden drie hoofdvormen onderscheiden (Bexell et al., 2010): representatieve, participatieve en deliberatieve democratie. Bij de eerste variant, de representatieve democratie, staan formele verantwoordingsrelaties tussen bevolking, volksvertegenwoordigers en de overheid centraal. In ons land wordt deze vorm voornamelijk gekenmerkt door de parlementaire democratie. Zoals in de meeste westerse democratieën zijn in ons land de politieke partijen de belangrijkste vertegenwoordigende organen (Mair en Thomassen, 2010). Ze vervullen van oudsher een dubbelfunctie, namelijk articulatie van maatschappelijke belangen en hoeder (als oppositiepartij) of uitvoerder (als coalitiepartij) van regeringsverantwoordelijkheid. De delegatieketen tussen individuele burger, politieke partijen, parlement en regering is de kern van de democratische verantwoording in parlementaire democratieën. De bewindslieden kunnen door de parlementsleden ter verantwoording worden geroepen, die op hun beurt zijn gekozen door de kiezers.

Deliberatieve democratie gaat over de kwaliteit van besluitvorming: hoe komen besluiten tot stand en wat is de inhoud van het uiteindelijke resultaat. De verantwoordingsmechanismen liggen hierbij veel meer besloten in de kwaliteit van de besluitvormingsprocedures. Democratische besluitvorming wordt als legitiem gezien als ze tot stand gekomen is door middel van geïnformeerde discussies, waarbij een gezamenlijke verkenning van

3 A. Lincoln, The Gettysburg address, 19 november 1863; beschikbaar op: Voices of Democracy, www.voicesofdemocracy.umd.edu. 
alternatieven en argumenten vooropstaat (Steiner et al., 2005; Habermas, 1996; Naurin, 2010). 'Democratic politics, according to this view, should be more about giving good reasons than forcing or striking deals. Arguing discussion on the merits - rather than bargaining or voting is at the heart of democracy' (Naurin, 2010, p. 31).

In Nederland krijgt de deliberatieve democratie vorm in het model van consensusbesluitvorming. Een consensusdemocratie wordt gekenmerkt door politieke instituties en beleidspraktijken die gericht zijn op verdeling van de macht en compromisvorming in plaats van op meerderheidsbesluitvorming (Andeweg, 2000, p. 511). Arend Lijphart, in zijn beroemde studie van het Nederlandse politieke systeem, bedacht de term 'consociational democracy' (1969) om de typische combinatie van gesegregeerde bevolkingsgroepen en samenwerking en consensusvorming in diplomatenstijl door de elite aan te duiden. Het begrip consensusdemocratie verwijst zowel naar formele institutionele arrangementen als naar informele beleidspraktijken, waarbij op een coöperatieve wijze zo veel mogelijk actoren betrokken worden, die besluitvorming op basis van (enkelvoudige) meerderheden proberen te voorkomen (Beyers et al., 2015, p. 4).

Bij participatieve democratie staat burgerparticipatie centraal. Voorstanders van participatieve democratie vinden dat de rol van burgers verder moet gaan dan periodiek als kiezer te fungeren, en dichten een grotere en meer omvattende rol toe aan burgers in het politiek-bestuurlijke besluitvormingsproces (Barber, 2003). Over het gehele politieke spectrum zijn er voorstanders van participatieve democratie omdat het enerzijds voldoet aan het liberale ideaal van een kleine overheid, en anderzijds aan het meer links georiënteerde ideaal van sterke, verbonden gemeenschappen. Participatieve democratie varieert van betrokkenheid van stakeholders ten behoeve van een gevarieerde inbreng voorafgaand aan de besluitvormingsfase, tot de betrokkenheid van burgers tijdens de besluitvormingsfase en een meer grassroots-variant waarin de actieve organisatie van initiatieven van burgers wordt gestimuleerd, de recent gelanceerde zogenaamde doedemocratie (ROB, 2012; WRR, 2012). Verantwoordingsmechanismen die hierbij van belang zijn, gaan met name over de mate van toegang tot allerlei burgerinitiatieven en directe burgerbetrokkenheid, en van responsiviteit van de overheid ten opzichte van de individuele burger.

Op basis van deze drie hoofdvormen kunnen drie type verantwoordingsmechanismen die van belang zijn voor het democratisch gehalte van het poldermodel geïdentificeerd worden. Vanuit het perspectief van de representatieve democratie staat de inbedding in het democratische besluitvormingsproces centraal, in het bijzonder de relaties met politieke 
partijen en (semi-)publieke (uitvoerings)organisaties. Vanuit het perspectief van de deliberatieve democratie is de kwaliteit van het besluitvormingsproces van belang. En ten derde is de mate van belangenarticulatie en belangenaggregatie vanuit het perspectief van participatieve democratie een relevant verantwoordingsmechanisme.

\section{De relatie met de overheid}

Vanuit het perspectief van de representatieve democratie is de inbedding van belangenorganisaties binnen het democratische besluitvormingsproces van belang. Hierbij zijn de relaties met politieke partijen en (semi-)publieke organisaties relevant. Van oudsher vervullen politieke partijen de dubbelfunctie van belangenarticulatie en regeringsverantwoordelijkheid en waren de relaties tussen belangenorganisaties en politieke partijen met name gebaseerd op politiek-ideologische eensgezindheid. Hierdoor konden politieke partijen en belangenorganisaties min of meer als communicerende vaten gezien worden. Sommige politieke partijen zijn ontstaan uit sociale bewegingen, of er was een hechte relatie tussen bijvoorbeeld de vakbondsbewegingen en sociaaldemocratische partijen of tussen agrarische werkgeversbelangen en christelijk-democratische partijen (Allern en Bale, 2012).

Recent lijken politieke partijen zich steeds meer te richten op bestuurlijke taken (Mair, 2013) in plaats van op hun rol als volksvertegenwoordiger. De middenpartijen bewegen zich steeds meer naar elkaar en de staat toe en zijn veel minder geneigd om hun volksvertegenwoordigende taak te benadrukken. Deze zogenaamde kartelpartijen (Katz en Mair, 2009) die hierdoor ontstaan, lijken nauwelijks nog van elkaar te verschillen. Door de toenemende focus op bestuursverantwoordelijkheden en steeds minder uitgesproken politiek-ideologische verschillen tussen de partijen, zullen de onderlinge relaties, die min of meer als vaststaand gegeven konden worden beschouwd, nu veel meer fluïde worden. Er zal veel meer sprake zijn van adhoccontacten en gelegenheidscoalities die al naar gelang het desbetreffende dossier van karakter kunnen verschillen, en veel meer gebaseerd zijn op onderlinge uitruil van expertise versus toegang tot het besluitvormingsproces dan op langdurige politiek-ideologische overeenstemming.

Belangenorganisaties springen als het ware in het gat dat de brede, mainstream politieke partijen laten vallen en geven zo vorm aan de functie van belangenarticulatie. Denk hierbij aan de rol van ngo's, bijvoorbeeld Stichting Wakker Dier bij de recente plofkip-campagne om supermarkten te bewegen diervriendelijkere producten in de schappen te leggen. Volgens 
Moisés Naím, een vooraanstaand internationaal politiek-econoom, is dit zelfs een van de meest cruciale ontwikkelingen in het functioneren van de democratie: 'De grote beslissingen worden genomen door politieke partijen die totaal in verval zijn' (...) 'activisten, sociale bewegingen, nietgouvernementele organisaties zijn veel succesvoller geworden dan politieke partijen om onderwerpen aan te dragen, mensen te engageren. ${ }^{4}$ Dit betekent dat de achterban en de rol van belangenorganisaties veel minder zijn gekoppeld aan politieke vertegenwoordiging en steeds meer als een losstaand element gaan functioneren in de democratische rechtsstaat. Daarmee gaat het indirecte verantwoordingsmechanisme verloren van de voorheen sterkere politiek-ideologische koppeling tussen politieke partijen en belangenorganisaties.

Daarnaast overleggen en onderhandelen met name de sociale partners maar ook andere belangenorganisaties direct met (semi-)publieke organisaties zoals de ministeries in Den Haag of uitvoeringsinstanties zoals toezichthouders of andere zelfstandige bestuursorganen, over wetgevingstrajecten of het tot stand komen van (sociale) akkoorden. Sterker, het poldermodel is voornamelijk gebaseerd op deze buitenparlementaire betrokkenheid van sociaaleconomische belangen in zowel het beleidsvormings- als het uitvoeringsproces. Deze vorm van belangenbehartiging is deels problematisch omdat deze externe actoren zich buiten het formele democratische verantwoordingsmechanisme bevinden, dat vooral via de vertegenwoordigende en controlerende functie van het parlement verloopt.

\section{De kwaliteit van het besluitvormingsproces}

De kwaliteit van de beleidsinbreng en, meer nog, de effectiviteit van de beleidsuitkomsten zijn de elementen van het Nederlandse poldermodel die veruit de meeste aandacht hebben gehad in de literatuur. Hierbij staat de effectiviteit van het bipartite- en tripartiteoverleg tussen vakbonden en werkgeversorganisaties en de overheid en sociale partners voor het functioneren van de nationale economie centraal.

Deze output legitimacy is niet het meest doorslaggevende criterium voor het democratisch gehalte en het adequaat functioneren van het poldermodel. Daarbij staat ook de manier waarop de akkoorden en wetsvoorstellen tot stand komen centraal. Hierbij zijn twee min of meer tegenovergestelde perspectieven mogelijk. Enerzijds kunnen de overleggen in kleine kring

4 'Tijd voor een Uber voor de politiek', interview Moisés Naím, NRC Handelsblad, zaterdag 8 en zondag 9 augustus 2015, E2-E3. 
en achter gesloten deuren - kenmerkend voor het (neo)corporatisme bijdragen aan kwalitatief hoogwaardigere besluitvorming. Deze overlegstructuren lijken namelijk bij te dragen aan onderling vertrouwen en het inhoudelijk bijstellen van beleidsposities tijdens de beleidsoverleggen. Een van de verklaringen hiervoor is juist het hoge achterkamertjesgehalte van de overleggen. Dit kan de kwaliteit van de besluitvorming ten goede komen (Naurin, 2007), omdat de deelnemers minder extreme posities hoeven in te nemen om hun reputatie ten opzichte van hun achterban te beschermen. De typische gesloten overlegstructuur tussen de politiek-bestuurlijke elite lijkt in het algemeen genomen wel tot effectieve beleidsuitkomsten te leiden. Dit is ook iets wat blijkt uit empirische studies naar de effectiviteit van sociaaleconomisch beleid in consensusdemocratieën ten opzichte van meerderheidsdemocratieën (Lijphart, 1999). Het Akkoord van Wassenaar is hier bij uitstek een voorbeeld van. Dit akkoord wordt vaak gezien als keerpunt van de economische crisis in de jaren 80 . Het succesvolle akkoord tussen werkgevers en werknemers maakte de weg vrij voor economisch herstel en ontstond in 1982 na jaren van animositeit, mislukte overleggen en tegengehouden hervormingen (Visser en Hemerijck, 1997).

Anderzijds kan deze achterkamertjespolitiek ruimte bieden aan politiek opportunisme en zo een uitgeholde institutionele reflex worden (Braun, 2015). Illustratief in dit verband is de akkoordenwoede van 2013. Het tweede kabinet-Rutte sloot in het eerste regeringsjaar akkoord na akkoord (zie ook Hemerijck en Van der Meer in deze bundel). In het voorjaar van 2013 alleen al werden binnen ongeveer een maand tijd het sociaal akkoord, het zorgak koord en het woonakkoord gesloten. Het sociaal akkoord werd door premier Rutte in april 2013 zelfs gepresenteerd als 'historisch' en als het nieuwe Akkoord van Wassenaar. Premier Ruttes associatie hiermee moest op dezelfde succesvolle wijze het einde van de recente economische crisis aankondigen. Niet alleen het sociaal akkoord werd de hemel in geprezen. Het energieakkoord dat in het najaar van 2013 werd gesloten werd door onderzoeksjournalisten van De Groene Amsterdammer zelfs getypeerd als 'de herontdekking van de polder' (Mommers et al., 2013).

De akkoordenwoede uit het eerste regeringsjaar van Rutte II lijkt slechts een kortstondige en reflexmatige opleving van het Nederlandse poldermodel geweest te zijn. In plaats van een terugkeer naar succesvolle en duurzame samenwerking, lijken deze processen vooral het resultaat van te veel ad hoc politiek opportunisme. Het zorgakkoord werd bijvoorbeeld wel door alle vakbondskoepels ondertekend, maar de grootste lidorganisatie van vakcentrale FNV, Abvakabo FNV, weigerde het akkoord te ondertekenen. Behoud van werkgelegenheid stond voor deze bond bovenaan, en dit tekende 
zowel de richtingenstrijd binnen de FNV als de opvolgingsstrijd rond het voorzitterschap. ${ }^{5}$ En amper drie maanden na het ondertekenen van het sociaal akkoord leek datzelfde akkoord tot stof te vergaan. De werkgevers bekritiseerden publiekelijk de gemaakte afspraken toen bleek dat de miljardenbezuinigingen toch doorgezet werden om het begrotingstekort in de pas te houden met de Europese eisen. ${ }^{6}$ De Raad van State (2013) typeerde de akkoordenwoede in zijn jaarverslag van 2013 als symptomatisch voor het gebrek aan slagkracht en wees op het beperkte legitimiteitsgehalte van deze vormen van besluitvorming, die in die periode vaak achter gesloten deuren plaatsvonden. De kwaliteit van het besluitvormingsproces is een ingewikkeld verantwoordingsmechanisme, omdat een deel van het proces achter gesloten deuren plaatsvindt en het lastig is de kwaliteit van de argumentatie te beoordelen.

\section{Aggregatie en articulatie van sociaaleconomische belangen}

Belangenorganisaties hebben een belangrijke aggregatie en articulatiefunctie van maatschappelijke belangen. Dit betekent idealiter dat zij op basis van de belangen van hun achterban hun beleidsinbreng formuleren en daarom een organisatiestructuur hebben die recht doet aan deze functies, met ofwel voldoende mogelijkheden voor inbreng van de leden ofwel voldoende mogelijkheden om zich op de hoogte te stellen van het reilen en zeilen van de doelgroep waarvoor ze opkomen. Alhoewel veel belangenorganisaties formeel dergelijke procedures kennen, zijn er in de praktijk belangrijke hindernissen. Dat heeft enerzijds te maken met de steeds complexere politiek-bestuurlijke besluitvormingsprocedures en de toenemende internationalisering, en anderzijds met de door de overheid overgehevelde publieke verantwoordelijkheden en de rol in de beleidsuitvoering.

De steeds complexere politiek-bestuurlijke besluitvorming vereist vergaande professionalisering van belangenorganisaties, met name om een adequate vertaalslag van de wensen van de achterban naar politiekbestuurlijk jargon te maken en een goede timing te kiezen in het politieke proces. Dit heeft als consequentie dat belangenorganisaties een professionaliseringsslag zullen moeten maken om op meerdere beleidsterreinen

$5 \quad$ NRC.next, En er ligt weer een akkoord, 26 april 2013; de Volkskrant, Zorg, de kwestie die voor het sociaal akkoord te heikel was, 22 april 2013.

6 Algemeen Dagblad, Liefde in de polder bekoeld, 29 juni 2013; Het Financieele Dagblad, 'Ik ben akkoordenmoe; de volgende keer doe ik niet meer mee', 25 juni 2013; de Volkskrant, 'Het moet anders, we moeten uit die spiraal', 27 juni 2013. 
relevante expertise te kunnen brengen, en tegelijkertijd dat de medewerkers van belangenorganisaties steeds meer gerekruteerd worden op basis van inhoudelijke expertise dan op affiliatie met de achterban (Maloney en Van Deth, 2012; Klüver en Saurugger, 2013). Belangenvertegenwoordiging wordt zo steeds meer een professionele aangelegenheid, waarbij democratische besluitvormingsstructuren en de verbanden met de achterban steeds meer verwateren. Het voorbeeld van de scheidend directeur van MKB-Nederland die in 2013 uit onvrede met de koers van MKB-Nederland een eigen belangenorganisaties oprichtte, is daar een treffend voorbeeld van. Volgens eigen zeggen richtte hij ONL voor Ondernemers op omdat 'we werken in structuren van vroeger. Ik geloof niet meer in brancheorganisaties. Ik merk bij alle ondernemers dat ze veel meer op basis van thema's en ambities willen samenwerken. Die behoefte is heel groot, maar de branches staan die ambitie in de weg. ${ }^{17}$ Meer in het algemeen is de oprichting van meer specialistische belangenorganisaties - dat wil zeggen, belangenorganisaties die zich op een enkel aspect richten - een teken dat de bredere koepelorganisaties moeite hebben om alle belangen binnen een sector of branche te vertegenwoordigen, en ruimte bieden aan andersoortige concurrenten (Lowery et al., 2012). Dit is ook terug te zien in het fenomeen dat veel lidorganisaties van de grote koepelorganisaties zelfstandig een lobby organiseren, door ofwel zelf te lobbyen ofwel een lobbyadviesbureau in te huren.

Daarnaast geldt voor de sociale partners niet alleen het aspect van toenemende politiek-bestuurlijke complexiteit en daarmee steeds hogere eisen aan professionaliteit en hoogwaardige expertise, maar ook het feit dat de deelnemende organisaties aan het sociaaleconomisch overleg van oudsher ook uitvoeringverantwoordelijkheden toebedeeld hebben gekregen, iets wat overigens de laatste twee decennia verminderd is door de veranderende rol van de sociale partners in de sociale zekerheid. Met andere woorden, belangenorganisaties krijgen deels een publieke status toegewezen. De Wet op het algemeen verbindend en onverbindend verklaren van verklaringen van collectieve arbeidsovereenkomsten (Wet AVV) in 1937 illustreert dit goed. Met de Wet AVV zijn ook de bedrijven die niet deelgenomen hebben aan de cao-onderhandelingen gehouden aan het cao-akkoord, wat de rol van de sociale partners een publieke functie toekent. De resultaten zijn namelijk van toepassing op een gehele branche of sector en zullen ook sector-breed nageleefd moeten worden.

In corporatistische wijst de overheid stelsels vaak proactief organisaties aan als vertegenwoordiger van een bepaald economisch belang of sector, 
of stimuleert zij de vorming van koepelorganisaties die geacht worden de sector te vertegenwoordigen en als gesprekspartner te fungeren. De expliciete overheidssturing in enerzijds de selectie van organisaties voor het reguliere beleidsoverleg en anderzijds de toekenning van publieke taken aan deze organisaties, heeft een doorslaggevend effect op hoe deze organisaties zich organiseren, en daarmee op de mobilisatie en articulatie van maatschappelijke belangen (Braun en Fraussen, 2015; Fraussen, 2014). Door een bepaalde organisatie structureel toegang te verlenen worden bepaalde groepen bij voorbaat uitgesloten van toegang. Hierdoor kunnen 'latente' belangen ontstaan die niet of nauwelijks vertegenwoordigd worden of zichtbaar zijn, omdat ze buiten dit systeem van garandeerde toegang vallen. Daarnaast kan deze garandeerde toegang ervoor zorgen dat belangenorganisaties zich in plaats van als vertegenwoordigers van een bepaald sociaaleconomisch belang naar voornamelijk mede-uitvoerders van overheidsbeleid ontwikkelen.

Door de complexiteit van de politiek-bestuurlijke besluitvorming en de selectie van de overheid van belangenorganisaties die als vertegenwoordiger en mede-uitvoerder van beleid fungeren, ontstaat min of meer dezelfde ontwikkeling als bij politieke partijen.

Kortom, we zien dat voor de relatie met de overheid het functioneren van belangenorganisaties en sociale partners grotendeels buiten de formele delegatieketen plaatsvindt, wat inherent is aan een parlementaire stelsels. Bij de kwaliteit van het besluitvormingsproces is het lastig zicht te krijgen op een zorgvuldige afweging van verschillende belangen, en bij de functie van belangenaggregatie en articulatie lijkt verwatering op te treden vanwege de toegenomen complexiteit van de politiek-bestuurlijke besluitvorming, professionalisering en de rol van beleidsmakelaars die veel belangenorganisaties op zich nemen.

\section{Een democratische meetlat voor het Nederlandse poldermodel}

Als we het poldermodel vanuit de verschillende dimensies van representativiteit bekijken, dan lijkt een verschuiving naar de meer beschrijvende dimensie van representativiteit te hebben plaatsgevonden. Belangenorganisaties worden uitgenodigd of willen zelf deelnemen aan het onderhandelingsproces op basis van veronderstelde gelijkenis in functionele (denk aan de verschillende organisaties voor zpp'ers) of sociaal-demografische zin (denk aan jongerenafdelingen binnen vakbonden). Tegelijkertijd zien we dat een aantal belangrijke verantwoordingsmechanismen, de relatie met de 
overheid, de kwaliteit van het besluitvormingsproces en de belangenaggregatie en -articulatie aan cruciale veranderingen onderhevig zijn. Hiermee is de vertaalslag van beschrijvende representativiteit naar substantiële representativiteit onzeker. Wat betekent dit alles voor het democratisch gehalte van het poldermodel? Als conceptueel startpunt van een evaluatie hiervan, kunnen we de verschillende vormen van representativiteit en verantwoordingsmechanismen samenvoegen tot een verzameling van criteria die als uitgangspunt kunnen dienen om het democratisch gehalte van het poldermodel te beoordelen (vgl. Lowery et al., 2015, p. 1226-1227). Deze criteria zijn in figuur 2.1 weergegeven en vormen onderling verbonden elementen. Deze onderlinge verbondenheid is bedoeld om de samenhang van de verschillende elementen tot uitdrukking te brengen, zowel in de analyse als in de beoordeling van het democratisch gehalte van het poldermodel.

Het eerste aspect om het democratisch gehalte van het poldermodel te beoordelen is de latente sociaaleconomische belangen (sociaaleconomische belangenarticulatie). Hierbij gaat het om het feit of alle relevante sociaaleconomische belangen in voldoende mate een stem krijgen in de samenleving of in voldoende mate zichtbaar worden. Latente belangen is het geheel aan verschillende sociaaleconomische belangen dat gehoord en gezien zou moeten worden. Hier zit tegelijkertijd een van de meest venijnige aspecten om een oordeel te geven over het democratisch gehalte. Dit aspect van latente sociaaleconomische belangen zou theoretisch gezien het ijkpunt moeten zijn voor de verschillende vormen van representativiteit en de oorsprong voor de verschillende verantwoordingsmechanismen. Het is namelijk nodig om inzichtelijk te maken wie of wat vertegenwoordigd zouden moeten worden om te spreken van een evenredige belangenvertegenwoordiging. Tegelijkertijd heeft het maatschappelijk middenveld, en de sociale partners in het bijzonder, geen helder ijkpunt zoals we dat aantreffen bij individuele burgerparticipatie tijdens verkiezingen, namelijk one citizen, one vote. 'Belangen' zijn een sociaal(wetenschappelijk) construct, die lastigdaadwerkelijk in de praktijk zichtbaar en meetbaar zijn te maken (vgl. Lowery et al., 2015, p. 1212-1213). Het wordt daarmee moeilijk om precies de vinger te leggen op de kwestie welke sociaaleconomische belangen er nu eigenlijk leven in de maatschappij, en wanneer een bepaalde beleidsuitkomst het publieke belang schaadt of alleen een deelbelang in ogenschouw neemt. Vaak wordt min of meer impliciet aangenomen dat een bepaalde geobserveerde beleidsuitkomst voorbij gaat aan het publieke belang. Dit is vrijwel altijd het geval als het gaat om schandalen vanuit het bedrijfsleven waarbij wordt aangenomen dat een onvolkomen product is 
Figuur 2.1 Een democratische meetlat voor het Poldermodel

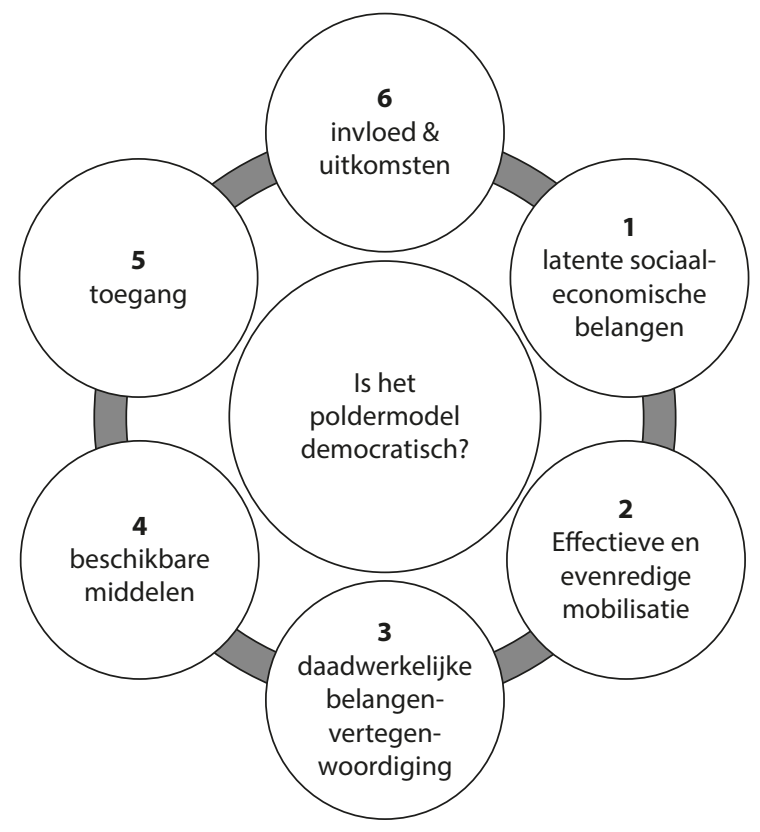

geproduceerd met onvoldoende oog voor de algemene gezondheid of het klimaat, maar enkel uit winstbejag. Illustratief hiervoor is het paardenvleesschandaal in 2013, waarbij paardenvlees als rundvlees werd verkocht, en het Volkswagenschandaal in 2015, waarbij de auto's willens en wetens zodanig gefabriceerd waren dat ze meer uitstoot hadden dan aanvankelijk uit de testresultaten bleek. ${ }^{8}$

Het tweede punt, effectieve en evenredige mobilisatie, gaat over het proces hoe het geheel aan latente sociaaleconomische belangen die leven in de maatschappij daadwerkelijk een gezicht en een stem krijgen. Met andere woorden, welke belangen mobiliseren zich succesvol. Dit kan gaan over nieuwe sociaaleconomische belangen die vanuit de maatschappij ontstaan en een georganiseerde vorm aannemen. Denk hierbij weer aan de zzp'ers, waarvoor gedurende de laatste decennia geleidelijk aan steeds meer organisaties zijn ontstaan die zich sterk maken voor de belangen van deze 'beroepsgroep'. Maar het kan ook gaan om bestaande organisaties die nieuwe sociaaleconomische belangen een gezicht geven. Bijvoorbeeld de

8 NRC Handelsblad, NVWA start groot onderzoek naar paardenvlees, 14 februari 2013; NRC Handelsblad, Rampweek voor topmerk, 26 en 27 september 2015. 
vakbonden, die nu bijna allemaal jongerenthema's of jongerenafdelingen hebben of zich specifiek richten op de positie van etnische minderheden of vrouwen binnen de arbeidsmarkt. Het gaat er bij dit element vooral om dat alle belangen die leven in de maatschappij de bijbehorende organisatie en mobilisatiecapaciteit krijgen. Dit is vaak niet het geval, denk aan de tegenstelling tussen de voedingsindustrie en de consumenten, waarbij de laatste veel belang hebben bij veilig, gezond maar betaalbaar voedsel, terwijl ze als collectief heel zwak georganiseerd zijn in vergelijking met de voedingsindustrie. Dit aspect heeft betrekking op de beschrijvende representativiteit, namelijk welke belangen actief vertegenwoordigd zijn en in hoeverre dat overeenkomt met alle relevante sociaaleconomische belangen voor een betreffend beleidsdossier.

Het derde punt, daadwerkelijke belangenvertegenwoordiging, draait om het feit of de bestaande belangenorganisaties de belangen die zij vertegenwoordigen op een adequate manier behartigen. Vaak wordt aangenomen dat brancheorganisaties de belangen van hun branche op een goede manier vertegenwoordigen, maar daar valt weinig over te zeggen zonder naar de belangenarticulatie en -aggregatie binnen de branche te kijken: worden alle verschillende stemmen - groot versus klein, grootstedelijk versus overige gebieden, importeurs versus exporteurs, om een paar voorbeelden te noemen - in gelijke mate meegenomen? En hoe organiseert een branche of koepelorganisatie de belangenarticulatie intern? Hierin komen de aspecten van substantiële representativiteit terug, en de interne organisatiestructuur van belangenorganisaties als belangrijk verantwoordingsmechanisme.

Het vierde punt, beschikbare middelen, heeft betrekking op de verschillende middelen die belangenorganisaties tot hun beschikking hebben. Daarbij gaat het niet alleen om de financiële middelen in de vorm van ledencontributies, subsidies of andere gelden. Dit punt heeft ook raakvlakken met de substantiële representativiteit, namelijk of de organisaties in staat zijn om hun achterban of branche goed te vertegenwoordigen. Niet zozeer in inhoudelijke zin, zoals bij de daadwerkelijke belangenvertegenwoordiging, maar meer in strategisch opzicht: weten ze de juiste prioriteiten te stellen en wenden ze de juiste strategische middelen aan. Hebben ze, met andere woorden, voldoende capaciteit in huis om hun stem te laten horen bij zowel de beleids- en besluitvormers die van belang zijn voor hun dossier, als in de media en anderszins als dat nodig is.

Het vijfde punt, toegang, heeft betrekking op de mate van toegang die belangenorganisaties hebben tot de beleids- en besluitvormers op het juiste niveau en op de juiste manier. Hebben ze bijvoorbeeld, gezien de groei van het sociaaleconomische belang dat ze vertegenwoordigen - denk weer 
aan zzp'ers - op een legitieme wijze toegang tot de belangrijke formele besluitvormingsarena's, zoals in het poldermodel de SER en de StvdA. En weten ze de weg te vinden naar de belangrijke wetgevende en uitvoerende echelons. Of, zoals Thom de Graaf (2013, p. 11) het eerder verwoordde: 'Formeel heeft iedereen gelijkelijk toegang tot die Haagse democratie, materieel moet je de weg kennen of mensen kennen die de weg weten.' Dit hangt nauw samen met de relaties met politieke partijen en de overheid als verantwoordingsmechanismen en in hoeverre ze de beschikbare middelen daadwerkelijk kunnen verzilveren.

Het zesde punt, tot slot, invloed en uitkomsten, gaat over de mate van invloed op de uiteindelijke beleids- en besluitvorming en in hoeverre deze te herleiden is tot de verschillende belangenorganisaties en sociale partners (Dür, 2008; Lowery, 2013). Hierbij gaat het niet alleen om hoe effectief individuele arbeidsmarkthervormingen, loonmaatregelen of akkoorden zijn om de nationale economie goed te laten functioneren. Het gaat hierbij ook om de mate waarin de uiteindelijke beleidsuitkomsten alle relevante belangen in afdoende mate weerspiegelen, en dat er een legitieme basis ligt voor de afweging van de verschillende belangen.

\section{De democratische meetlat als ijkpunt: enkele voorbeelden}

Om tot een zorgvuldige weging van het democratisch gehalte van de polder te komen zijn al deze facetten van belang. Maar vaak worden er maar een of twee aspecten belicht en wordt op basis daarvan oneigenlijke invloed of onevenredige vertegenwoordiging aangenomen. Een veel voorkomend onevenwichtig oordeel is dat vanuit element 6 (invloed en beleidsuitkomsten) direct de conclusie getrokken wordt dat er sprake is van onevenredige invloed van een bepaalde belangenorganisatie of bepaalde groep van actoren, meestal het bedrijfsleven. Illustratief voor de eerste variant is de regelmatig terugkerende kwestie van het Kamerlid of de Europarlementariër die de inbreng van belangenorganisaties haast letterlijk overneemt tijdens zijn/haar inbreng in een parlementair debat of overleg. Dit wordt vaak direct geïnterpreteerd alsof het Kamerlid zijn/haar oren te veel heeft laten hangen naar een bepaalde lobby. En dus, zo is de gedachte, is er sprake van oneigenlijke invloed en ondemocratische belangenbehartiging.

Met de democratische meetlat in de hand zien we dat dit slechts ten dele waar hoeft te zijn. Als we de cirkel achterwaarts langs lopen en starten bij het aspect van invloed, botsen we direct al tegen problemen aan. Want wie zegt dat het Kamerlid daadwerkelijk beïnvloed is door de belangenorganisatie/lobbyist in kwestie? Het vaak gehoorde instrument van lobbyisten: 'wij 
brengen een pakkend verhaal ter onderbouwing van het standpunt'9 doet hier zijn intrede. Het is een veel waargenomen en verklaarde praktijk dat belangenorganisaties de Kamerleden/politieke partijen opzoeken die het dichtst bij hun standpunt liggen, om die vervolgens van munitie te voorzien in het politieke debat (Hall en Deardorff, 2006). Maar is er dan sprake van invloed: als jij mij mee uit lunchen vraagt rond lunchtijd, heb je mij dan overtuigd en daarmee beïnvloed, of had ik toch al honger en was ik al van plan om te gaan lunchen op dat tijdstip (vgl. Lowery, 2013). En om dan nog maar niet spreken over andere problematische aspecten van het definiëren en meten van invloed (Dür, 2008; Lowery, 2013). Of er sprake is, vervolgens, van onevenredige vertegenwoordiging, weten we pas als we de relevante andere sociaaleconomische belangen rond deze kwestie in kaart gebracht hebben en weten of deze ook op een net zo effectieve manier hun stem hebben kunnen laten horen (dit zijn de elementen van toegang, middelen en effectieve belangenvertegenwoordiging van de democratische meetlat) en of alle hoorbare stemgeluiden inderdaad een goede reflectie zijn van alle sociaaleconomische belangen die leven in de maatschappij en die relevant zijn voor het dossier in kwestie (de elementen van latente sociaaleconomische belangen, effectieve en evenredige belangenvertegenwoordiging en daadwerkelijke belangenvertegenwoordiging).

Een tweede voorbeeld van de hink-stap-sprong van invloed naar oneigenlijke inbreng van bepaalde actoren is de verhouding tussen het midden- en kleinbedrijf en het grootbedrijf in het Nederlandse poldermodel en in internationaal opzicht. De veronderstelling is vaak dat het grootbedrijf een enorm machtige positie heeft, en zonder doelbewust strategisch handelen macht uitoefent op publieke en politieke besluitvorming - de zogenoemde these van de structurele macht (vgl. Van Apeldoorn, 2011). Illustratief daarvoor is de mystiek waarmee het besloten gezelschap De Pijp is omhuld. Het staat bekend als club voor topmannen en president-commissarissen van grote Nederlandse concerns, die met enige regelmaat bijeenkomt in kasteel Wittenburg in Wassenaar. ${ }^{10}$ De assumptie is dat dit een invloedrijk gezelschap is, zoals vaak wordt aangenomen over de positie van het grootbedrijf in de Nederlandse politieke besluitvorming. En nog vaker wordt aangenomen dat het grootbedrijf onevenredig invloedrijk is. Alhoewel het

$9 \quad$ NRC Handelsblad, 'Wat zit er eigenlijk achter uw soep? Economie E12-13, zie bijlage tomatensoep NRC over de voedingsindustrie, 12 september 2015.

10 NRC Handelsblad, 'Gewoon wat harder je best doen', 29 augustus 2015, weekendbijlage; $N R C Q$, http://www.nrcq.nl/2015/o8/29/bijna-geheim-genootschap-van-topmannen-komt-bijeen-inwassenaar. 
van naïviteit zou getuigen om de invloed van het Nederlandse grootbedrijf te marginaliseren, is onevenredige invloed niet noodzakelijkerwijs altijd een-op-een te concluderen. Als de assumptie van onevenredige invloed van het grootbedrijf waar is, dan zouden we verschillende zaken moeten waarnemen. Ten eerste zouden de handelingen en besluiten van de politiek in lijn moeten zijn met de belangen van het grootbedrijf, los van het feit of het grootbedrijf aan bewuste beïnvloedingspogingen heeft gedaan (Van Apeldoorn, 2011). Daarnaast zouden we onsuccesvolle tegenmobilisatie moeten waarnemen. Niet alleen een onsuccesvolle aggregatie van belangen en effectieve en daadwerkelijke mobilisatie en belangenvertegenwoordiging van andere sociaaleconomische belangen (elementen 1, 2 en 3 van de democratische meetlat), maar ook structureel minder toegang van deze andere sociaaleconomische belangen (element 5). Dus om daadwerkelijk het oordeel te kunnen vellen dat wet- en regelgeving enkel in het belang van het grootbedrijf is en dat het grootbedrijf niet het grotere algemene belang vertegenwoordigt (element 6 van de democratische meetlat), is inzicht in alle andere elementen ook nodig, iets wat vaak ontbreekt.

Naast de extrapolaties, gerelateerd aan specifieke beleidsuitkomsten, geeft enerzijds het (beperkte) lidmaatschap en participatie van individuele burgers of individuele bedrijven binnen deze belangenorganisaties en anderzijds de zichtbaarheid in het beleidsproces van deze organisaties, ook vaak aanleiding tot de aanname dat er sprake is van een ondemocratisch gehalte. Zo zien we bijvoorbeeld dat, ondanks afnemende ledenaantallen van de vakbonden en een gebrekkig sturend vermogen van de centrale brancheorganisaties (Visser, 2007), de Nederlandse overheid structureel met de vakbonden blijft overleggen.

Al gedurende een aantal decennia neemt het vakbondslidmaatschap in Nederland gestaag af. Het lidmaatschap kwam in 2011 neer op 20 procent van de beroepsbevolking (SCP, 2014). Niet alleen historisch gezien een dieptepunt, maar ook in Europees verband is de organisatiegraad van de vakbonden in Nederland laag (SCP, 2014). Mannen van boven de 45 die werkzaam zijn in het publieke domein en de bouwnijverheid met een vaste baan vormen de grootste categorie van het vakbondslidmaatschap (SCP, 2014, p. 119-124). Bij de beschrijvende representativiteit is dit problematisch, maar de belangrijkere kwestie is of de dominante zittende leden in voldoende mate de belangen van minderheidsgroeperingen zowel binnen als buiten de achterban adequaat vertegenwoordigen. De vakbonden vertegenwoordigen feitelijk de belangen van grote groepen werknemers binnen alle sectoren, als gevolg van de Wet AVV van 1937 (zie boven), waardoor de representatieve functie van de vakbonden duidelijk is verbonden aan een algemeen, meer 
publiek belang, namelijk dat van alle werknemers en bedrijven binnen de cao-sectoren. Om hier de conclusie te kunnen trekken dat de vakbonden hun legitimiteit verliezen in het onderhandelingsproces is het van belang om ook de eerdergenoemde throughput legitimacy mee te nemen. In hoeverre functioneren binnen de vakbonden namelijk alle ledengroepen en bestuursarrangementen zodanig dat binnen die vakbonden opinies gevormd worden die redelijkerwijs de communis opinio van alle werknemers binnen een bepaalde sector vertegenwoordigen. En dat is uiteraard de vraag, omdat de oudere, vaak mannelijke werknemers met een vast contract geheel andere belangen hebben op de arbeidsmarkt dan andere doelgroepen, waaronder zzp'ers, jongeren, vrouwen en migranten. Het gaat hierbij dan niet zozeer om het verschil in sociaal-demografisch opzicht, maar om de verschillende functionele belangen die hiermee samenvallen met betrekking tot hun arbeidsmarktpositie binnen de verschillende sectoren.

De democratische meetlat maakt, kortom, twee belangrijke aspecten inzichtelijk. Niet alleen vraagt een oordeel over het democratisch gehalte van het poldermodel, om het proces van belangenarticulatie, aggregatie en toegang tot het beleidsproces per besluitvormingstraject of type organisatie te beoordelen. Maar ook de rol van de overheid is van belang om de uiteindelijke belangen af te wegen en belangenorganisaties bij de besluitvorming te betrekken.

\section{Het democratisch gehalte van de polder: is het glas halfvol of halfleeg?}

In zijn boek, Je hebt het niet van mij, maar... concludeerde Joris Luyendijk (2010) dat de macht in Den Haag bij een handjevol grote belangenorganisaties, een aantal topambtenaren, een aantal journalisten en een enkel Kamerlid ligt. Zijn boek schetst een beeld van publieke besluiten die vooral tot stand komen door wheeling \& dealing, achterkamertjespolitiek en een old boys network met (meer dan) een goed glas wijn in Nieuwspoort. Zijn dertig dagen durende antropologische studie heeft hemzelf in grote mate verwonderd. Voor de ervaren bestuurders was het een feest der herkenning of een wrange bevestiging van wat men toch al wist: de toegang tot politiek Den Haag lijkt nogal onevenredig verdeeld. Van het Nederlandse poldermodel wordt vaak hetzelfde beweerd: niet alle sociale partners hebben een evenredige stem en in werkelijkheid is het het Nederlandse bedrijfsleven, in het bijzonder het Nederlandse grootbedrijf, dat aan de touwtjes trekt. $\mathrm{Al}$ is het naïef om te veronderstellen dat het Nederlandse bedrijfsleven 
bij monde van de belangrijkste koepelorganisaties en lobbyisten niet of nauwelijks invloed heeft, van sterke onevenredige invloed en een ondemocratisch gehalte kan pas echt gesproken worden als de verschillende aspecten van de democratische meetlat in ogenschouw genomen worden. Hierbij moet overigens niet de indruk gewekt worden dat dit een uitputtend evaluatie-instrument is; het geldt meer als een goed aanknopingspunt voor een systematische evaluatie of empirische analyse.

De evaluatie van het poldermodel heeft altijd sterk geleund op output legitimacy, de bijdrage van het overlegmodel aan een goed functionerende nationale economie - in het model het zesde aspect, namelijk de beleidsuitkomsten. Tegelijkertijd zien we dat veel van de huidige fricties veel meer te maken hebben met input en throughput legitimacy, waarbij het ontbreken en het gebrekkig functioneren van verantwoordingsmechanismen centraal staat. De mate waarin de sociale partners hun leden daadwerkelijk vertegenwoordigen, de mate waarin ze in staat zijn een sector of branche op verschillende beleidsterreinen adequaat te vertegenwoordigen, en in hoeverre de sociale partners überhaupt de sociaaleconomische belangen in Nederland in zijn geheel genomen goed vertegenwoordigen, zijn onmisbare elementen bij het beoordelen van het democratisch gehalte van het poldermodel.

De democratische meetlat biedt niet alleen aanknopingspunten voor een volledigere evaluatie (en daarmee meer systematisch onderzoek) naar het democratisch gehalte van het poldermodel, maar ook aanknopingspunten om hervormingen in die richting kritisch te beoordelen. We zien recentelijk steeds vaker initiatieven om inzichtelijk te maken welke sociaaleconomische belangen betrokken zijn bij de beleids- en besluitvorming door middel van bijvoorbeeld de veelgehoorde 'lobbyparagraaf', waarbij het duidelijk is welke belangenorganisaties of lobbyisten bepaalde inbreng hebben geleverd in wetgevingstrajecten. De assumptie is dat deze vorm van transparantie inzichtelijk maakt wie bij het proces betrokken is en in hoeverre deze partijen invloed hebben gehad. Vaak wordt dan alleen aan het eerste criterium voldaan, namelijk inzichtelijk maken wie er betrokken is geweest. Met andere woorden, hiermee wordt met name de input legitimacy bediend. Voor de throughput legitimacy helpen dergelijke initiatieven niet noodzakelijkerwijs: op basis van een lobbyparagraaf kunnen we nog niets zeggen over de afweging die door de besluitvormers is gemaakt en in hoeverre deze afweging disproportioneel beïnvloed is door de bij het beleidsvormingsproces betrokken partijen. Daar is het ook voor nodig dat de daadwerkelijke afweging inzichtelijk gemaakt wordt.

En dat brengt me bij een laatste punt om het democratisch gehalte van het poldermodel te kunnen beoordelen. Hierbij gaat het niet alleen om de 
mate van (oneigenlijke) invloed die belangenorganisaties proberen uit te oefenen, maar ook om de weging van deze verschillende belangen aan de kant van politieke besluitvormers. Aan hen de schone taak om de belangen die worden ingebracht zorgvuldig af te wegen en mee te nemen in hun uiteindelijke beleidsvoorstellen. Inderdaad: 'De kracht van de lobby wordt (...) bepaald door de kracht van de democratie' (De Graaf, 2013). Oftewel, voor een goed functionerend poldermodel is een overheid met een visie nodig (Prak en Van Zanden, 2013). En die heeft niet alleen betrekking op de inrichting en aansturing van de nationale economie door middel van het overlegmodel, maar daarnaast ook op het democratisch gehalte en daarmee het duurzaam functioneren ervan. De wijze waarop belangenorganisaties structureel worden betrokken bij de besluitvorming en beleidsuitvoering vraagt niet alleen een goed overzicht van de latente sociaaleconomische belangen, maar ook een zorgvuldige weging van deze belangen om tot een goede einduitkomst te komen en daarmee de uiteinden van de democratische meetlat bij elkaar te brengen (aspect 1 en 6). Deze focus op de input en throughput legitimacy van het poldermodel laat zien dat het democratisch gehalte van het poldermodel voor verbetering vatbaar is. 


\title{
3 Past de overlegeconomie nog in de wereld van globalisering en Europese integratie?
}

\author{
Jelle Visser
}

Het boek A Dutch Miracle - met de ondertitel Job Growth, Welfare Reform and Corporatism in the Netherlands - verscheen eind september 1997, op het hoogtepunt van de internationale aandacht en roem die Nederland tijdens het EU-voorzitterschap eerder dat jaar ten deel viel. De reden voor die roem, zo schreven wij (Visser en Hemerijck, 1997), lag in 'het Nederlandse werkgelegenheidswonder' dat een einde had gemaakt aan de 'dramatische werkloosheidscrisis' van de jaren 8o. In 1997 was de werkloosheid in Nederland gedaald tot 5,5 procent van de beroepsbevolking, terwijl Europawijd de werkloosheid al enkele jaren 10 procent of meer bedroeg. Geen wonder dat de Nederlandse banengroei aandacht trok. Naast de snelle banengroei en sterke daling van de werkloosheid (figuur 3.2), viel de spectaculaire stijging van de werkgelegenheidsgraad op (figuur 3.1). Kort daarop werd in het kader van het Europese werkgelegenheidsbeleid de 70-procentnorm bedacht, die alleen door Nederland, de Noordse landen, Groot-Brittannië en sinds kort ook door Duitsland wordt gehaald.

In ons boek verdedigen we de stelling dat voor het Nederlandse banenwonder een 'interne devaluatie' nodig is geweest, die mede door de vakbeweging is gesteund. Dit moet niet groter gemaakt worden dan het is. Het Akkoord van Wassenaar van eind 1982 maakte een reële loondaling mogelijk dankzij de afschaffing of niet-toepassing van de automatische prijscompensatie, bij een inflatie die in 1982 5,9 procent en in 19832,7 procent bedroeg. Maar ook na dat akkoord was er heftig verzet tegen de destijds internationaal uitzonderlijke 3 procent nominale loondaling in de publieke sector in 1983 die rechtstreeks doorwerkte in de minimumlonen en sociale uitkeringen. En tot in de jaren 90 was er vakbondsbreed verzet tegen aanpassingen in de sociale zekerheid. Maar de bijdrage verdient ook geen geringschatting. Het herstel van de concurrentiepositie werd niet opgelegd door internationale organisaties en liet het institutionele kadervan de arbeidsverhoudingen, gebaseerd op erkenning van vakbeweging en cao, ongemoeid. Dat het ook anders kan leren de recente 'interne devaluaties' in enkele zuidelijke Eurolanden, waar hervormingen, opgelegd door de trojka 
Figuur 3.1 Werkgelegenheidsgraad

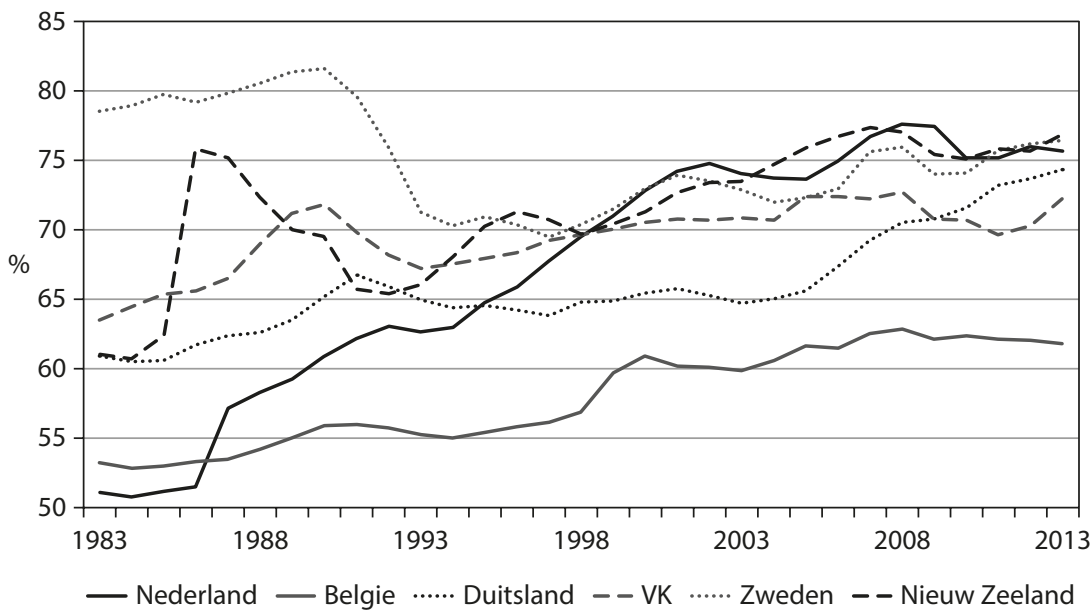

Bron: OESO, OECD.stat

Figuur 3.2 Werkloosheidspercentage

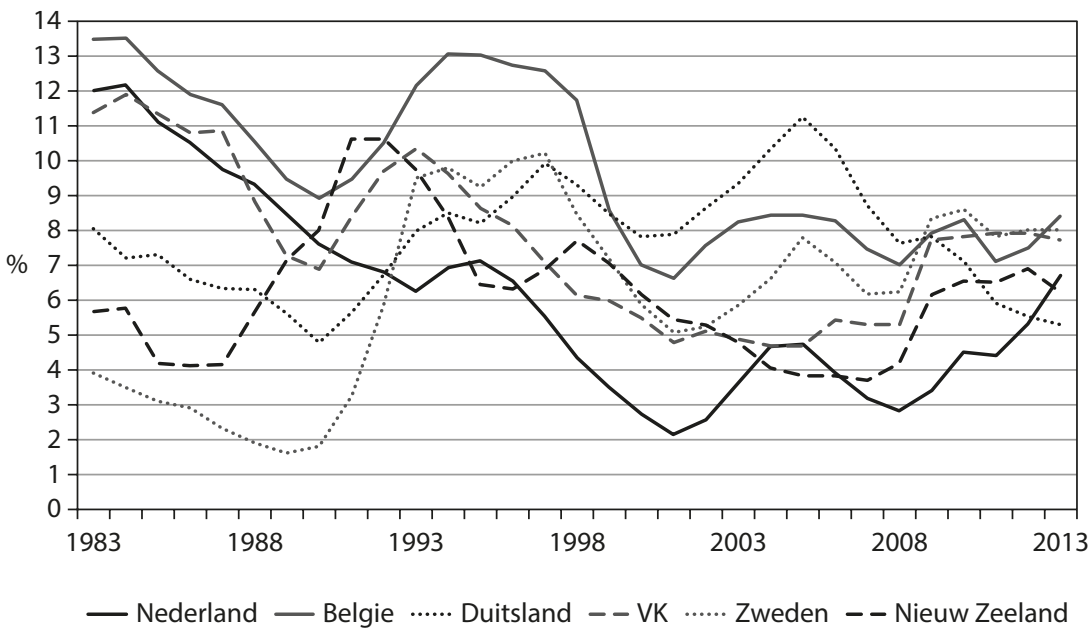

Bron: OESO, OECD.stat

van de Europese Unie, de Europese Centrale Bank en het Internationaal Monetair Fonds, samengaan met dikwijls dramatische veranderingen in de arbeidsverhoudingen (Marginson en Welz, 2014; Visser, 2016). 


\section{Nederland in vergelijking}

In dit hoofdstuk probeer ik twee vragen te beantwoorden. Wat is of wat was de waarde van de overlegeconomie? En hoe staat het met de houdbaarheid van het Nederlandse corporatisme, of, anders geformuleerd, staat de overlegeconomie op gespannen voet met globalisering en de transitie naar een dynamische en open diensteneconomie? Ik zal dezelfde onderzoeksmethode gebruiken als in hoofdstuk 2 van ons Miracle-boek: vergelijking van de Nederlandse beleidsuitkomsten en ontwikkelingen met enkele overeenkomstige en contrasterende landen. Mijn keuze is gevallen op Nieuw-Zeeland, België, Duitsland, Zweden en het Verenigd Koninkrijk.

Net als Nederland zijn België, Zweden en Nieuw-Zeeland 'stipjes op de wereldkaart' (De Rooy, 2014), afhankelijk van wat anderen doen en van de wereldmarkt. Ze hebben op die afhankelijkheid gereageerd met een uiteenlopende beleidsmix, en het relatieve succes zou dus iets kunnen zeggen over de waarde en bestendigheid van ons Nederlandse 'overlegmodel'. Duitsland is Europa's sterkste en grootste economie, en evenals Engeland, dat plaats 6 inneemt onder de G7-landen, net voor Italië, zou het de globale verhoudingen mogelijk kunnen beïnvloeden, al bestaat daar twijfel over. Bijvoorbeeld bij de in 2015 overleden oud-kanselier van Duitsland, Helmut Schmidt, die meent dat er nog slechts twee economische zwaargewichten, de Verenigde Staten en China, zijn overgebleven, met de Europese Unie, mits verenigd, als mogelijke derde. ${ }^{1}$ Ook Duitsland en het Verenigd Koninkrijk hebben met een zeer uiteenlopende beleidsmix op de uitdagingen van de globalisering gereageerd en staan er momenteel verschillend voor, Duitsland als de industrie- en exportnatie bij uitstek en Engeland als centrum van financiële dienstverlening. In beide landen werd net als in Nederland de arbeidsmarkt flink opgeschud, tegen de zin van de vakbeweging en met veel minder 'overleg' en 'medewerking' dan in ons land.

Nieuw-Zeeland beleefde in de jaren 90 eveneens een spectaculaire banengroei, maar vormt een bijna perfect contrast met Nederland in hoe dat bereikt werd. In Nieuw-Zeeland werd het bestaande cao-overlegkader volledig afgebroken - nog maar 15 procent van de werknemers valt onder een cao en er is geen enkele coördinatie - terwijl in Nederland het caooverlegkader bleef behouden en zelfs werd uitgebouwd - 85 procent van de werknemers valt onder een cao en er is nog altijd sprake van een stevige coördinatie (De Beer, 2013). Het is dus een ideale counterfactual. Hoe zou 
Nederland er nu voorstaan als er geen 'Wassenaar' geweest was en de NieuwZeelandse aanpak - weg met de cao en weg met het overleg - gevolgd zou zijn?

Tussen de Belgische en Nederlandse overlegeconomie bestaan daarentegen kleine verschillen. Niettemin lopen de beleidsuitkomsten fors uiteen (Van Ruysseveldt en Visser, 1996; Hemerijck et al., 200o). Terwijl beide landen drijven op de export en beschikken over een goed opgeleid arbeidsaanbod, bleef het werkloosheidspercentage in België over de hele periode 1982-2012 gemiddeld op 8 procent steken, tegen 4 percent in Nederland. Beide landen waren in het begin van de jaren 80 in een diepe crisis geraakt, met snel verdwijnende werkgelegenheid in de marktsector, een werkloosheidpercentage van boven de 12 procent, en een netto participatiegraad, of werkgelegenheidsgraad, van $5^{1}$ (Nederland) respectievelijk 53 (België) procent. In Nederland is de netto participatiegraad met hulp van deeltijdbanen sindsdien gestegen naar $7^{6}$ procent, in België is deze blijven steken op 62 procent. Daarmee is België het enige land van de zes landen die ik hier vergelijk dat de 70-procentnorm van de EU niet haalt (zie tabel 3.1).

Als liberale versus gecoördineerde markteconomie en vanwege hun economische en politieke betekenis voor Nederland, zijn het Verenigd Koninkrijk en Duitsland de twee polen waartussen het Nederlandse beleid zich beweegt. Vijfendertig jaar geleden was het Verenigd Koninkrijk het eerste en enige Europese land met een regering die vastbesloten was dat de economische neergang alleen gestopt kon worden door een einde te maken aan de invloed van de vakbonden en het stelsel van cao-onderhandelingen (Howell, 2005). De scherpe koerswijziging in 1979 na de verkiezingswinst van de Conservatieve Partij onder Margaret Thatcher had drie kenmerken (Crouch, 1990, p. 326). Ten eerste, 'de vrijwel volledige verwerping door de conservatieve regering van het zoeken naar een nationaal compromis in de arbeidsverhoudingen, iets dat tot dan toe het beleid van alle politieke partijen sinds tenminste 1940 (...) had gekenmerkt'. Ten tweede, 'het stellen van zeer beperkende grenzen aan het handelen van de vakbonden' en, ten derde, 'de opkomst van de onderneming als belangrijkste terrein van de arbeidsverhoudingen'. Dit derde kenmerk werd allengs overal belangrijker en vertaalde zich in een wereldwijde tendens tot decentralisatie in de arbeidsverhoudingen, die met name in de jaren 90 en tijdens de recente 'Grote Recessie' versneld werd (Visser, 2016). De overige kenmerken ontbreken, althans in West-Europa (maar niet in Nieuw-Zeeland, of in de Verenigde Staten). De Britse Sonderweg vertaalde zich in een versnelde neergang van de maakindustrie en opbouw van de financiële dienstverlening, aanvankelijk 
blijvend hoge werkloosheid, matige banengroei, het verdwijnen van de bedrijfstak-cao en een gering cao-bereik, en sterk toegenomen ongelijkheid.

Duitsland, daarentegen, bleef vasthouden aan zijn stelsel van georganiseerde arbeidsverhoudingen, gekenmerkt door verregaande autonomie voor de sociale partners, maar zag zich geconfronteerd met de zware opgave van de hereniging van de twee Duitslanden na 1989. In de jaren go gold Duitsland in economisch opzicht als de ‘zieke man' van Europa, met blijvend hoge werkloosheid, uitblijvende banengroei, later gevolgd door stagnatie in de lonen en besteedbare inkomens van huishoudens. Inmiddels, sinds 2005, na een zware ingreep in de arbeidsmarkt en de werkloosheidsuitkeringen, beleeft Duitsland een periode van herstel, die anders dan bij ons niet sterk geleden heeft onder de Grote Recessie (Carlin et al., 2014), met een aanhoudende groei van de werkgelegenheid en daling van de werkloosheid (zie figuur 3.1 en 3.2). Door het uittreden van steeds meer ondernemingen staat de sector-cao er onder druk en het bereik is in twintig jaar gedaald van 85 naar $5^{8}$ procent. In loon-ongelijkheid en verschillen in marktinkomens steekt Duitsland het Verenigd Koninkrijk inmiddels naar de kroon.

Zweden blijft in menig opzicht een ideaal van vooruitstrevend beleid, al is daar wel wat glans vanaf. De zware financiële crisis waarin het land rond 1990 belandde, leidde tot een voor Zweden ongekende stijging van de werkloosheid tot 10 procent van de beroepsbevolking en een blijvende daling van de netto participatiegraad, die nog altijd heel hoog is. Ook in Zweden volgde een reeks van beleidsaanpassingen door achtereenvolgende conservatieve, liberale en sociaaldemocratische coalitieregeringen (Dølvik et al., 2014), maar net als in België, Duitsland en Nederland, en in tegenstelling tot Nieuw-Zeeland of het Verenigd Koninkrijk, waren dit aanpassingen die de naoorlogse verzorgingsstaat en arbeidsverhoudingen intact lieten.

Uit onderstaande tabel 3.1, met gegevens uit 2012 of 2013, kunnen we opmaken dat Nederland, gevolgd door Zweden, aan kop gaat wat betreft bruto nationaal product per hoofd van de bevolking. Het is het minst geïndustrialiseerde van de zes landen. Hier valt vooral het contrast op met Duitsland en, in mindere mate, België, dat van oudsher een sterke maakindustrie bezat. Met een aandeel van import en export, elk bijna even groot als het totale nationale product, springt Nederland er samen met België uit als transito-economie. We zien tevens dat Duitsland en Zweden, met een veel kleiner aandeel van de totale export, een verhoudingsgewijs kwalitatief hoogwaardige exportbijdrage leveren. De veel grotere bijdrage van onderzoek en ontwikkeling in beide landen, en de achterblijvende investeringen in R\&D in Nederland en België (en nog sterker in NieuwZeeland en het Verenigd Koninkrijk) zullen daar mede debet aan zijn. 


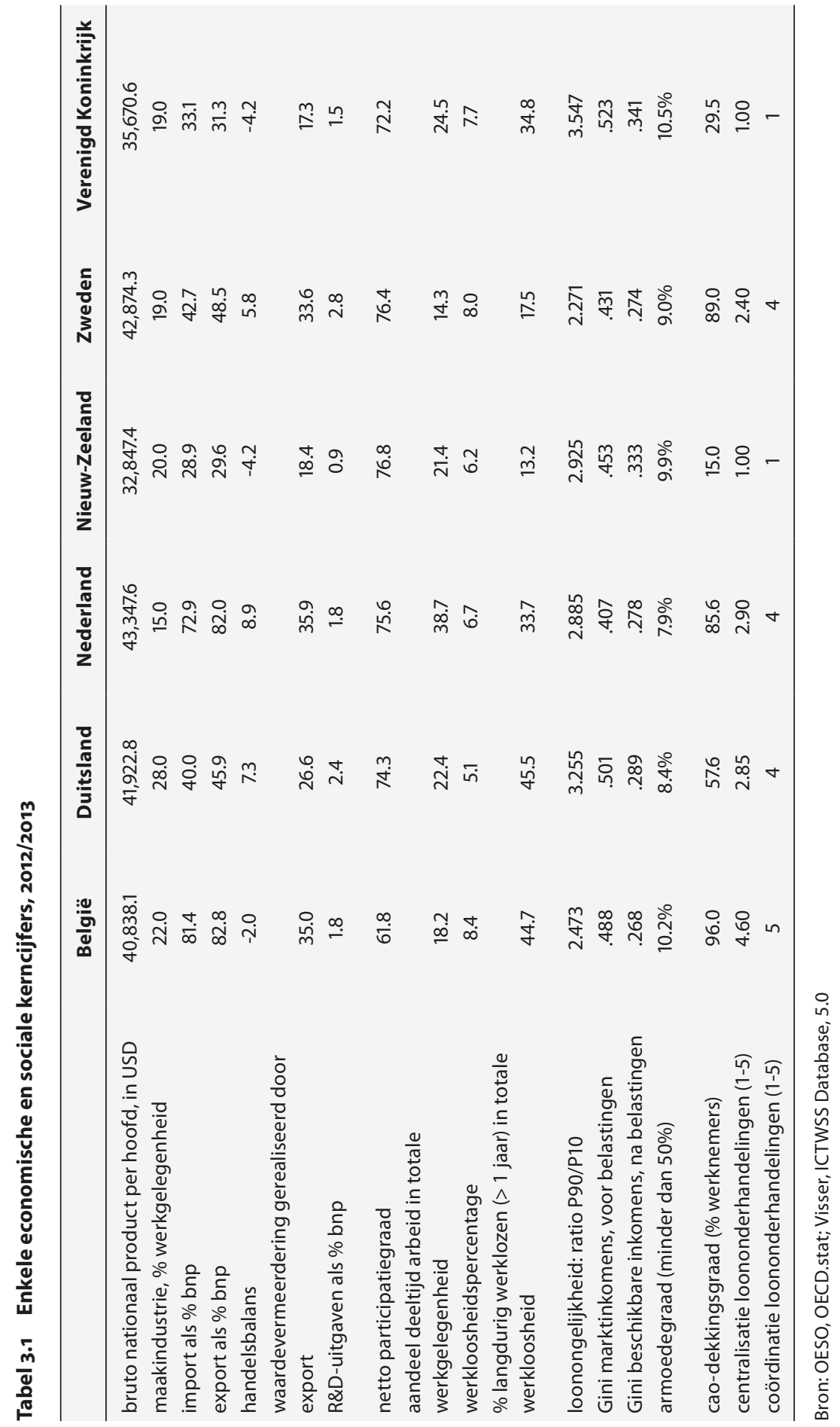


Opvallend is het grote positieve overschot op de handels- en betalingsbalans, een positie die Nederland gemeen heeft met Duitsland en Zweden, terwijl België, het Verenigd Koninkrijk en Nieuw-Zeeland een negatief saldo hebben. Dit is een van de spanningen binnen het Eurogebied tussen enkele noordelijke landen en de meeste zuidelijke lidstaten inclusief Frankrijk en België. Hier worden verschillen in concurrentievermogen binnen Europa en op de wereldmarkt zichtbaar. België (net als Frankrijk en de zuidelijke Eurolanden) betaalt daarvoor met een hogere werkloosheid en geringere arbeidsdeelname. Het springt eruit met een netto participatiegraad die 10 tot 15 procentpunten lager ligt dan in de andere vijf landen. Nederland springt eruit met het hoge aandeel aan deeltijdbanen, waarvan heel veel kleine banen. Wat betreft het aandeel van de langdurige werkloosheid in de totale werkloosheid neemt Nederland een middenpositie in. De Zweedse en Nieuw-Zeelandse cijfers geven aan dat het beter kan.

Ten slotte, wat ongelijkheid betreft nemen Nieuw-Zeeland en het Verenigd Koninkrijk een apart positie in, in de zin van veel minder herverdeling via belastingen en verzorgingsstaat. Dat komt ook naar voren in de armoedecijfers. Echter, wat loonongelijkheid en ongelijkheid van marktinkomens betreft doet Nieuw-Zeeland het redelijk goed, ondanks de afwezigheid van collectieve arbeidsvoorwaardenvorming. Het geringe aandeel van huishoudens zonder marktinkomen heeft net als in Nederland een belangrijke bijdrage in vermindering van ongelijkheid vóór herverdeling door belastingen en verzorgingsstaat (Kenworthy, 2009).

\section{De waarde van de overlegeconomie}

Twee weken voor het verschijnen van A Dutch Miracle ontving de Stichting van de Arbeid, als de incarnatie van onze overlegeconomie, een internationale prijs voor, zoals het juryrapport het uitdrukte, 'de van hun verantwoordelijkheid bewuste politiek van kleine stappen die werkgevers en werknemers in Nederland met elkaar zijn overeengekomen'. De runnerup voor die prijs voor beste beleid was Nieuw-Zeeland. Na een scherpe crisis rond 1990 had zich daar eveneens volgend op een diepe crisis een 'werkgelegenheidswonder' voltrokken, zoals we konden zien in figuur 3.1 en 3.2. Voor het overige had het contrast niet groter kunnen zijn. Volgens de OESO-indicatoren voor baanzekerheid is Nieuw-Zeeland, samen met de Verenigde Staten en het Verenigd Koninkrijk, een van de landen waar werknemers, in vaste of tijdelijke dienst, de minste bescherming genieten, en Nederland een van de landen waar de meeste bescherming geldt. Alleen 
voor werknemers met tijdelijke contracten heeft Nederland de poorten wijd opengezet, voor werknemers met vaste contracten is er niet veel veranderd (zie tabel 3.2). We zullen verderop zien dat dit grote gevolgen heeft gehad voor de ontwikkeling van banen met standaardcontracten (onbepaalde tijd en ten minste 19 uur per week) en niet-standaardcontracten (tijdelijk, kleine deeltijdbanen en zelfstandigen in dienst van werkgevers) (Visser, 2013a).

Ook wat de arbeidsvoorwaardenvorming betreft vormen Nederland en Nieuw-Zeeland elkaars tegenpolen. Traxler et al. (2001, p. 209) noemen Nieuw-Zeeland het enige land in de OESO waar de regering het bereik van de cao moedwillig heeft beperkt door een keuze te maken voor individuele contractvorming, mogelijk gemaakt door een wetswijziging in 1991. Daarmee kwam een abrupt einde aan een eeuw van collectieve en tamelijk gecentraliseerde, door de overheid opgelegde regulering van de arbeidsmarkt, die haar oorsprong had in de Industrial Conciliation and Arbitration Act van 1894 - Nieuw-Zeeland was het eerste land ter wereld dat het mogelijk had gemaakt om een cao bij wet algemeen verbindend te verklaren. De Employment Contract Act van 1991 schrapte de plicht van werkgevers om met vakbonden over arbeidsvoorwaarden te onderhandelen, hief de bijzondere status van vakbonden als rechthebbende vertegenwoordigers van werknemers op en gaf aan individuele contractonderhandelingen de voorkeur boven cao-vorming (Harbridge, 1993). Vakbonden die werknemers met een zwakke positie op de arbeidsmarkt - in de landbouw, de bouw, de handel, logies, restaurants en toerisme - vertegenwoordigden, werden van de kaart geveegd, sectorcao's verdwenen en zelfs in de publieke sector werden individuele contracten gemeengoed (Schwartz, 200o). De vakbondsorganisatiegraad halveerde van 50 procent in 1990 tot 25 procent in 1996. De cao-dekkingsgraad, die 67 procent bedroeg in 1990, daalde in enkele jaren eveneens naar 25 procent. Tegenwoordig valt nog slechts 15 procent van de werknemers in Nieuw-Zeeland onder een cao (zie figuur 3.3).

In Nederland is er wat betreft de arbeidsvoorwaardenvorming op het eerste gezicht weinig veranderd. De organisatiegraad van de vakbeweging is sinds 1979 gehalveerd, van 36,6 procent toen naar 17,8 procent nu, maar de cao-dekkingsgraad is na een kleine dip in de jaren 80 op hetzelfde niveau van 8 o procent of meer van alle werknemers gebleven. De sector-cao is dominant gebleven, de helft van deze sector cao's wordt nog steeds algemeen verbindend verklaard (avv) en er wordt nog steeds stevig gecoördineerd op arbeidsvoorwaarden door de centrale organisaties van werknemers en werkgevers. Overheidsingrepen in het cao-overleg zijn sinds het Akkoord van Wassenaar uitgebleven en ook door de verandering van standaard-naar minimum-cao's met mogelijkheden van aanvullende onderhandelingen 


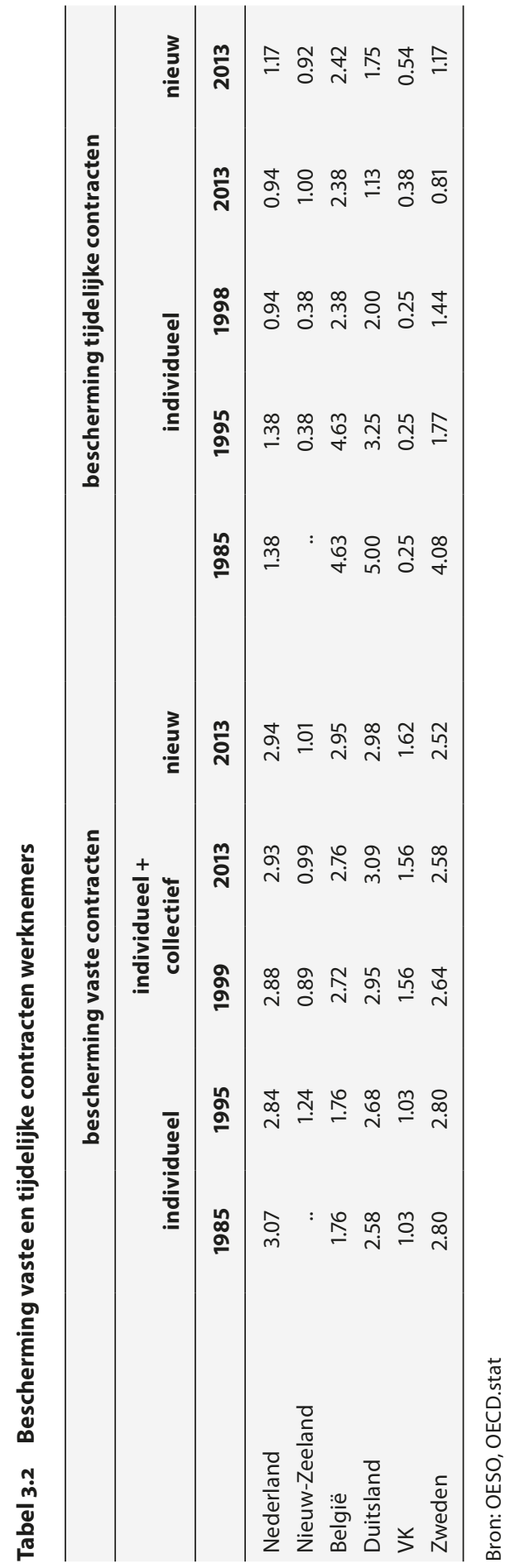


is er sprake van een geleidelijk proces van decentralisaties. Ondanks het leden- en machtsverlies van de vakbonden verloopt alles langs de weg der geleidelijkheid en is de cao er niet minder belangrijk op geworden. In dit opzicht wijkt Nederland scherp af van de ontwikkelingen in het Verenigd Koninkrijk, waar vrijwel alleen nog maar ondernemingscao's worden afgesloten, en die alleen nog maar voor een kleine minderheid van werknemers. Ook de erosie waarvan sinds de hereniging in Duitsland sprake is - met steeds meer bedrijven die uit de cao stappen - is aan Nederland voorbijgegaan (zie figuur 3.3).

Ten slotte is ook het contrast met België, waar sinds de jaren 80 de overheid steeds sterker de uitkomsten van het cao-overleg bepaalt, groot. Loonvorming via centrale akkoorden of per overheidsbesluit, zoals nu al weer bijna twintig jaar in België, heeft tot gevolg dat vrijwel iedereen de zelfde koek krijgt voorgezet. Uit de hoge cao-dekkingsgraad in Zweden en Nederland blijkt dat het ook zonder directe overheidsingrepen (taboe in Zweden en in onbruik geraakt in Nederland) ook mogelijk is, in Zweden zelfs zonder avv. Cruciaal is de organisatie van werkgevers en hun vermogen en wil om bedrijfstak-cao's afte sluiten. Dat hangt ook af van wat de vakbonden te bieden en te dreigen hebben.

Voor een counterfactual analyse van de Nederlandse ontwikkelingen na 1983 - wat zou er gebeurd zijn als de dood gewaande overlegeconomie

\section{Figuur 3.3 Cao-dekkingsgraad}

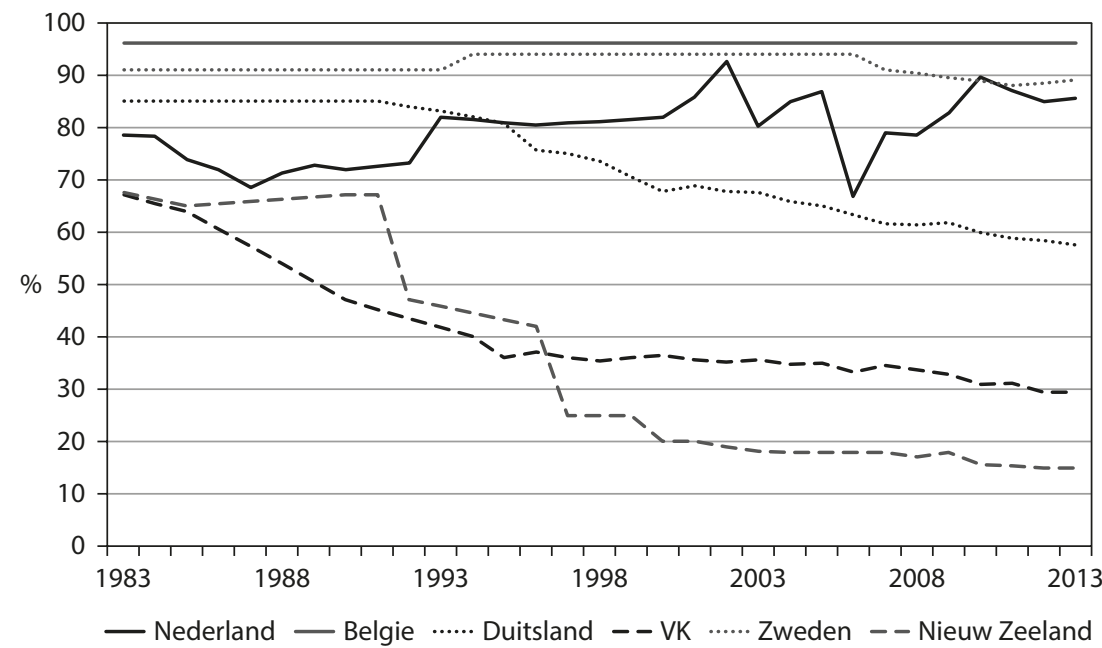

Bron: J. Visser, ICTWSS database 5.0. Amsterdam: AIAS 2015 
niet nieuw leven zou zijn ingeblazen? - is Nieuw-Zeeland een leerzaam voorbeeld. Zeker is dat zonder het Akkoord van Wassenaar er een of meer overheidsingrepen in de marktlonen zouden hebben plaatsgevonden, naar het patroon van voorgaande jaren. Bij voortgaand prestige- en machtsverlies van de vakbeweging en oplopende werkloosheid zouden meer werkgevers hun eigen weg zijn gegaan, zoals dat tien jaar later, na de Duitse hereniging, bij onze oosterburen is gebeurd (Hassel, 2003; Streeck, 2009). We weten niet wat de wetgever gedaan zou hebben. Zeker is dat de overlegeconomie na het Akkoord van Wassenaar in CDA-minister Jan de Koning, als minister van Sociale Zaken en Werkgelegenheid in een centrumrechtse regering die zich voorstond op een 'no nonsense' aanpak en belust was op liberalisering en deregulering van de arbeidsmarkt, een verdediger van formaat had. Zo was voor deze minister elke aanval op de algemeenverbindendverklaring van de cao - het mikpunt van liberale economen en later steen des aanstoots voor de OESO - kansloos. Toen rond 1990 het Nederlandse corporatisme op zijn dieptepunt was geraakt - met de drama's rond de WAO en de arbeidsbemiddeling, Zalms aanval op de avv en de parlementaire enquête naar het machtsmisbruik van de sociale partners - hadden vakbonden en werkgevers elkaar in het arbeidsvoorwaardenoverleg juist weer een beetje gevonden. Ongeveer tien jaar na Wassenaar hadden de werkgevers voldoende vertrouwen in de vakbeweging om een tweede centraal akkoord (Nieuwe Koers, 1993) te sluiten en samen met de vakbeweging op zoek te gaan naar meer differentiatie binnen en niet tegen de bestaande kaders van de bedrijfstak-cao (Visser en Van der Meer, 2011). Zonder Wassenaar geen herleving van de overlegeconomie tien jaar later. Een afkeer van de cao en van de vakbeweging, zoals die zich de afgelopen decennia massaal onder Britse werkgevers en ten dele ook in Duitsland heeft voorgedaan, zou zonder de gebleken compromisbereidheid van de Nederlandse bonden en het daaropvolgende succes van winsten en werkgelegenheid waarschijnlijk zijn geweest.

Mogelijk zou die banengroei, onder druk van overheidsingrepen, matiging van de lonen als gevolg van faillissementen en verder oplopende werkloosheid, en het toegenomen aanbod van vrouwen op zoek naar deeltijdwerk, er ook zonder de overlegeconomie wel zijn gekomen - later, minder exuberant en na een nog diepere crisis. En dus met een uitkomst die, net als in Nieuw-Zeeland en het Verenigd Koninkrijk, veel ongelijker zou zijn geweest, zowel in de inkomens- als beloningsverhoudingen, want met minder herverdeling van werk en inkomens, Uit mijn onderzoek met Susan Hayter van de ILO blijkt een duidelijk negatief verband tussen de cao-dekkingsgraad en het verschil in brutolonen tussen het negende en 
eerste deciel (zie figuur 3.4). Florence Jaumotte en Caroline Orsono Buitron (2015), twee onderzoeksters verbonden aan het Internationaal Monetair Fonds, constateren een stijging van de inkomensverschillen, vooral aan de bovenkant, bij een dalende vakbondsorganisatiegraad en vragen zich af of de generieke aanbeveling van het fonds om de arbeidsverhoudingen te decollectiviseren en te decentraliseren wel zo verstandig is. Uit recent Duits onderzoek komt naar voren dat als bedrijven uit de bedrijfstak-cao stappen dit met significante loonverliezen voor de werknemers gepaard gaat (Addison et al., 2014), terwijl onderzoek gedaan voor de Bertelsmann Stichting aantoont dat de erosie van de cao mogelijk een sterkere verklaring voor de toegenomen loonongelijkheid levert dan de toegenomen internationale handel (Felbermayr et al., 2014).

De waarde of 'opbrengst' van de overlegeconomie van de jaren 80 en 90 ligt, vermoed ik, niet alleen in economisch herstel of banengroei, evenmin in de herverdeling van betaald werk tussen mannen en vrouwen, maar in het feit dat deze ontwikkeling zich heeft voorgedaan binnen, en niet buiten de kaders van de cao en de door de vakbeweging geïnspireerde opvattingen over 'gelijk loon voor gelijk werk'. Daardoor zijn de inkomensverhoudingen veel minder scheefgetrokken dan in Nieuw-Zeeland of Groot-Brittannië. Het inzicht dat grote verschillen in inkomen een rem kunnen zijn op toekomstige groei, investeringen en deelname aan onderwijs, zoals al werd

\section{Figuur 3.4 Cao-bereik en loonongelijkheid in 2013}

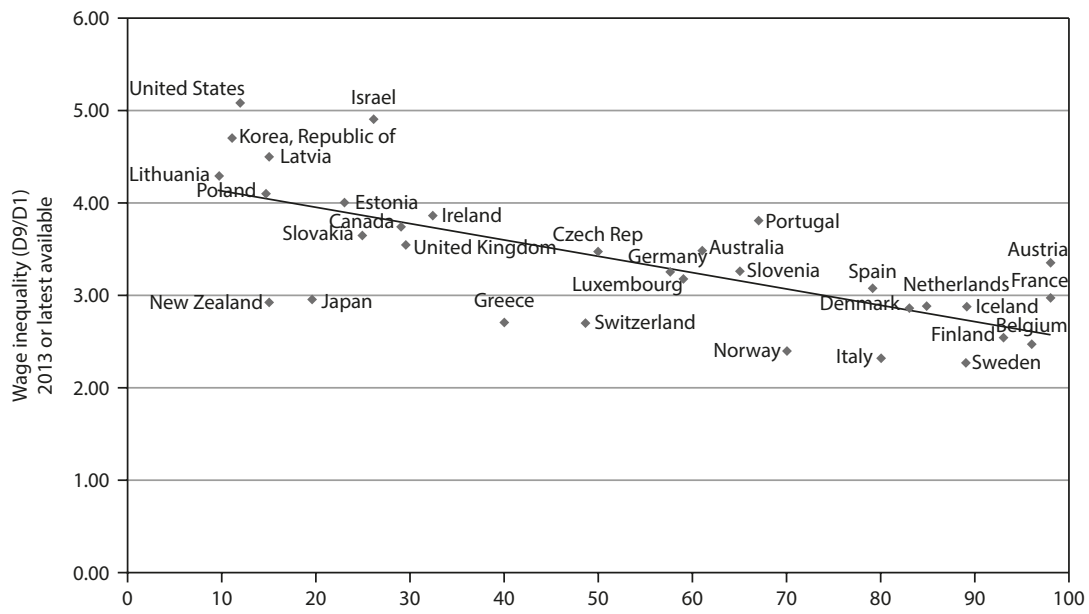

Bron: J. Visser, ICTWSS database 5.0. Amsterdam: AIAS 2015 voor cao-dekkingsgraad, en OECD.stat voor gegevensongelijkheid 
betoogd door Keynes in het slothoofdstuk van zijn General Theory, heeft recent nieuwe aandacht gekregen in publicaties van de OESO en de IMF (Jaumotte en Buitron, 2015).

Vergeleken met hoe Nieuw-Zeeland of Groot-Brittannië uit de crisis van de jaren 80 is gekomen, stond Nederland er eind jaren 90 in bijna alle opzichten beter voor. Of de oogst ook werd binnengehaald?

\section{De overlegeconomie en de toekomst}

De overlegeconomie is geen tijdloos gegeven. In A Dutch Miracle definiëren we corporatisme als de buitenparlementaire praktijk van samenwerken en onderhandelingen tussen belangenorganisaties onderling en met de overheid over de richting en uitvoering van het sociaaleconomisch beleid (Visser en Hemerijck, 1997, p. 66). De uitwerking van deze praktijk, en de wijze van samenwerken en onderhandelen, hangt af van zowel institutionele inbedding als maatschappelijke steun, en beide zijn aan veranderingen onderhevig. De fase die intrad na het Akkoord van Wassenaar omschreven we als 'herwonnen' en 'responsief' corporatisme, na een fase waarin de overlegeconomie in de jaren 70 haar brede maatschappelijke steun had verloren in de onderneming, in de samenleving en in de belangenorganisaties. Bij gelijkblijvende institutionele verankering had dit geleid tot een rituele praktijk van overleg zonder noemenswaardige resultaten, die wij typeerden als 'immobiel' corporatisme, waarin de wil om te veranderen afwezig was, niettegenstaande de oplopende kosten van de bestaande toestand voor de meeste betrokken partijen: verlies aan werkgelegenheid, dalende investeringen en winsten in de marktsector, oplopende overheidsuitgaven en belastingdruk, doodbloeden van de industrie en ledenverliezen bij de vakbonden. Partijen hielden elkaar tegen of schoven kosten door. Het gezagsverlies van centrale bestuurders en de angst om de eigen achterban met compromissen en onaangename feiten te confronteren - het verloren maatschappelijke draagvlak - verkleinden de mogelijkheid van compromissen. Pas de dreiging van verdere ontvlechting, tegen de achtergrond van een diepe economische crisis en een omslag in het politieke en maatschappelijke klimaat, leidde tot het herwonnen corporatisme - in feite een nieuw maatschappelijk engagement van de sociale partners.

De waardering voor 'responsief corporatisme' is gebaseerd op outputlegitimatie - bijna twee decennia lang was dat dus de bovengemiddelde banengroei in Nederland en de geleidelijke beleidsaanpassing van het 
arbeidsbestel die daarvoor nodig was: overheid uit de loonvorming en decentralisatie arbeidsverhoudingen; verbouwing en versobering van de sociale zekerheid, herdefiniëring van arbeids(on)geschiktheid; meer aandacht voor gezondheid en langer doorwerken; meer rechten en gelijkheid voor vrouwen en migranten; betere combinatie van arbeid en zorg. Mogelijk is dat anno 2015 uitgewerkt. Na 2000 presteert Nederland niet bovengemiddeld als het gaat om groei, werkgelegenheid of productiviteit. Integendeel, Nederland doet het heel matig (zie tabel 3.3), waarbij vooral de terugval tijdens de Grote Recessie (2008-2014) fors was.

We zien dat Nederland koploper was bij groei en werkgelegenheid in de eerste periode, tot ongeveer het jaar 2000, en daarna presteert onder het niveau van de andere landen. De productiviteitsontwikkeling is in beide perioden matig, en inmiddels bijna tot stilstand gekomen. Ook in de andere landen, met uitzondering van Nieuw-Zeeland, dat nu volop profiteert van de oriëntatie op de Aziatische markten, is sprake van groeivertraging, geringe banengroei en stagnatie in de productiviteit, in Nederland is de terugval evenwel het grootst. De drie laatste recessiejaren, waarin Nederland uitzonderlijk slecht presteerde mede dankzij veel te zwaar aangezette bezuinigingen die het laatste restje binnenlandse vraag en vertrouwen afknepen, kwamen extra hard aan, maar zelfs zonder die jaren is de groeivertraging opmerkelijk. We zien dat (in figuur $3.5 \mathrm{en}$ 3.6) ook in de ontwikkeling van de werkgelegenheid, vooral als we een uitsplitsing maken tussen 'standaardbanen' (contracten voor onbepaalde tijd en ten minste 19 uur per week) en 'substandaardbanen' (tijdelijk, voor bepaalde tijd, minder dan 19 uur per week, of schijnzelfstandigheid). ${ }^{2}$ We zien nu dat Nederland kampioen substandaardbanen is (in alle drie de categorieën: tijdelijke contracten, kleine deeltijdbanen en zzp'ers die vooral met één opdrachtgever te maken hebben) en dat de aanzienlijke groei van standaardbanen tussen 1983 en 1999 na 2000 tot stilstand is gekomen en in latere jaren zelfs een daling is ingetreden. Deze cijfers geven aanleiding te denken dat er sprake is van vervanging van standaardbanen door substandaardbanen.

Het beeld van de Nederlandse 'prestaties' moet krachtig genuanceerd worden. Anne Wren, Mate Fodor en Sotiria Theodoropoulou (2013) schrijven dat Nederland een van de meer succesvolle landen is in de opwaardering van diensten en toepassing van ict. Over de periode 1992-2006 wordt de

2 De drie categorieën zijn zo berekend en opgeteld dat geen dubbeltelling optreedt (zie Visser, $2013 a)$. 


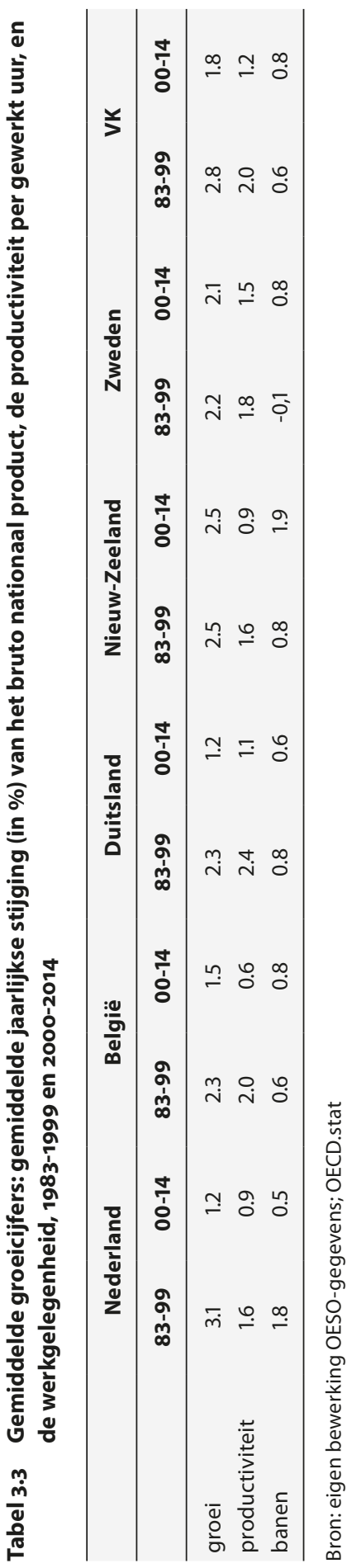


Figuur 3.5 Standaardbanen (als \% 15-65 bevolking)

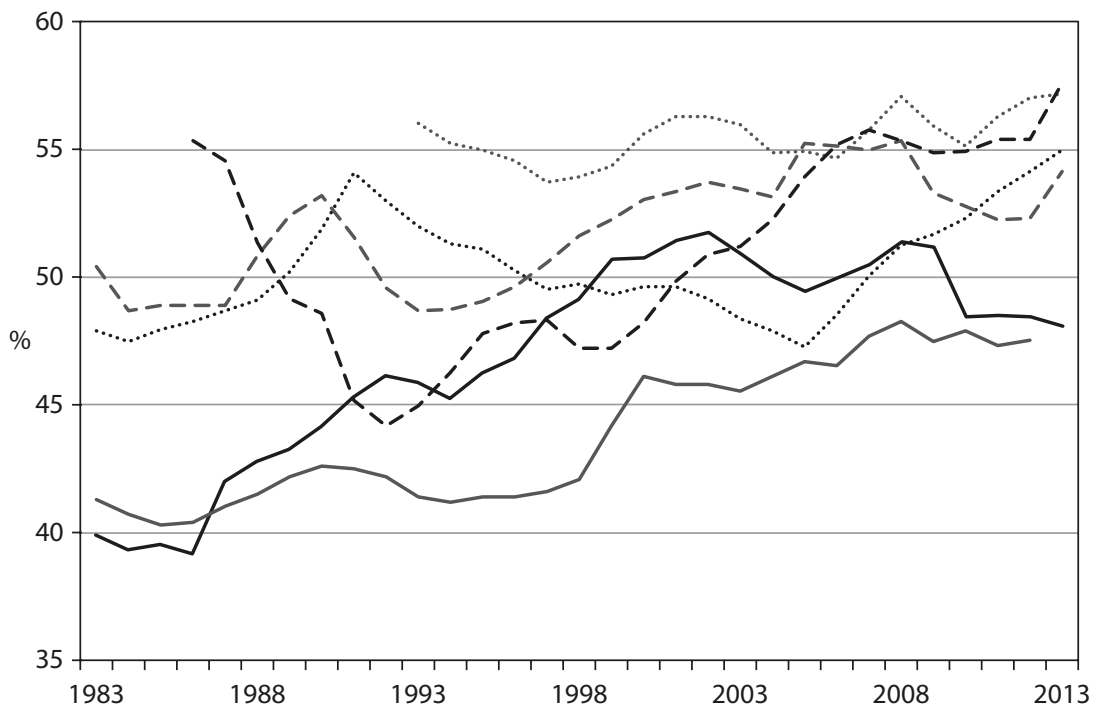

— Nederland — Belgie …... Duitsland ….... Zweden - - VK - - Nieuw Zeeland

\section{Figuur 3.6 Non-standaardbanen (als \% 15-65 bevolking)}

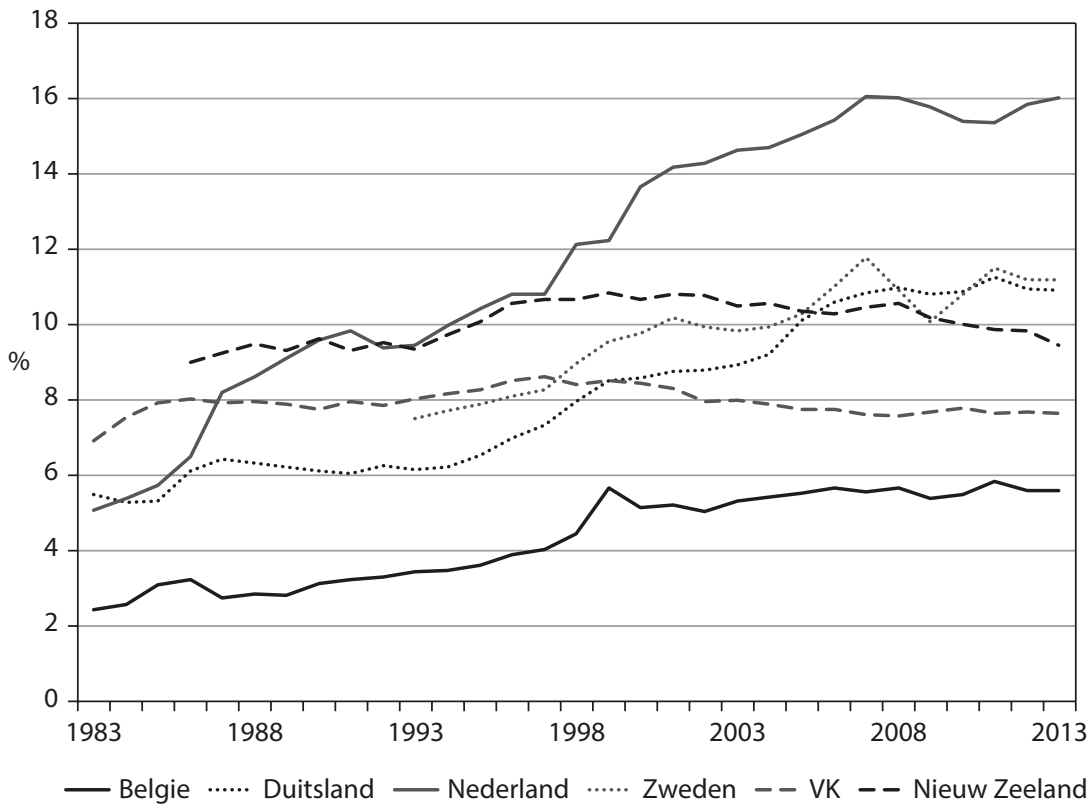


average ratio ofICT to value added in Nederland op .505 becijferd, vergeleken met 0.355 in Duitsland. In de financiële sector, ligt deze ratio bij 1.66 in Nederland vergeleken met .688 in Duitsland. Daarmee steekt Nederland ict-kampioen Zweden naar de kroon. Het raadsel is waarom dit niet terug te vinden is in de productiviteitscijfers.

De ict-ontwikkeling wordt ondersteund door de veranderingen in het onderwijssysteem. Uit de vergelijkende analyse van Karin Andersen en Anke Hassel (2013) maak ik op dat het Duitse stelsel op alle fronten (beroepsonderwijs, voorbereidend hoger en universitair systeem) bij het oude is gebleven en het Nederlandse stelsel daarentegen veel sterker heeft ingezet op generalskills en een krachtige uitbreiding van de derde fase (universiteit en hbo), veranderingen die volgens vele deskundigen beter passen bij een diensteneconomie. Volgens Wren, Fodor en Theodoropoulou (2013) zijn in de Nederlandse economie sinds de jaren 90 in relatieve zin meer hooggeschoolde banen in de 'traded or dynamic service sector' geschapen dan in enig ander Europees land. In hun analyse is Nederland een uitbijter (overigens samen met het Verenigd Koninkrijk) wat betreft de 'shift out of welfare sectors into dynamic internationally traded service sectors'.

De andere kant van het verhaal duidt op vormen van tweedeling met dalende kansen op vast werk van mensen met tijdelijke contracten (Dekker en Mooi-Reci, 2011) en verdringing aan de onderkant van de arbeidsmarkt door beter opgeleide jongeren en studerenden met kleine flexibele deeltijdbanen die de voorheen vaste banen van laaggeschoolden bezetten (Salverda, 2015). Er zijn redenen voor het vermoeden dat veel werkgevers het werk zo gereorganiseerd hebben dat er vooral plaats is voor kleine en flexibele contracten, en dat de vakbeweging te zwak is om de balans tussen flexibiliteit en zekerheid recht te zetten. Mogelijk is de vakbeweging te gepreoccupeerd met de bescherming van de vaste contracten en arbeidsvoorwaarden van een kleinere en ouder wordende groep werknemers (Visser, 2013a). Ik herinner aan de gegevens in tabel 3.2, met het vooral in Nederland scherpe contrast tussen de bescherming van werknemers met vaste en tijdelijke contracten.

Wat betekenen deze ontwikkelingen voor de overlegeconomie? Een mogelijke interpretatie is dat we weer in een vergelijkbare fase van het corporatisme zijn terechtgekomen als in de jaren 70: terugvallende maatschappelijke steun bij gelijkblijvende institutionele verankering. De tegenstribbelende steun aan hervormingen van de vakbeweging, het verzet van bestuurders en groepen kaderleden tegen veranderingen in pensioenaanspraken en ontslagbescherming, het dalende ledental, de grotere onenigheid binnen de FNV en tussen de centrales, het moeizame leiderschap - al deze ontwikkelingen duiden erop dat we ons in een moeizame fase van 
de overlegeconomie bevinden. Ik kan niet goed beoordelen of iets vergelijkbaars ook aan werkgeverskant speelt. De moeizame onderhandelingen over de cao's in 2014 en 2015 kunnen een teken van 'disengagement' zijn, of gewoon een antwoord op vakbondseisen die, na jaren van bezuiniging, matiging en recessie, nu eenmaal wat steviger zijn.

De bijdrage van de politiek en de vele en wisselende regeringscoalities na 2002 werd instabieler en ook dat kan hebben bijgedragen aan de toegenomen onzekerheid over de instituties van de overlegeconomie. Krachtige of ten minste consistente signalen uit politiek of markt, zoals in de beginjaren 8o, ontbreken. De Grote Recessie was niet een 'kritisch moment', zoals de crisis in de beginjaren 80 . De marktsector, de bedrijfsrendementen of de flexibiliteit aan de aanbodzijde van de arbeidsmarkt waren nu niet de issues; veeleer was er een probleem aan de vraagzijde, en een overheid die haar eigen problemen en uitgaven niet onder controle kon krijgen en ging bezuinigen op het verkeerde moment. Als 'loonmatigingsmachine' is de overlegeconomie in deze jaren uitgediend en mogelijk zelfs contraproductief.

De vraag of ons corporatisme toekomstbestendig is en helpt bij het verdedigen van Nederlandse belangen - van werkgevers, werknemers en burgers - in een verder globaliserende economie, zal van meer afhangen dan van coördinatie op lonen en loonkosten, en van loonmatiging. Looncoördinatie en loonmatiging blijven overigens belangrijk op kritische momenten. In Zuid-Europa hebben we kunnen zien hoe dat mis kan gaan en tot ingrepen van buitenaf kan leiden. Of is het zo dat ons model alleen maar goed is in loonmatiging? In dat geval heeft in mijn ogen het Nederlandse overlegmodel zijn tijd gehad, want gezien de flexibilisering van de arbeidsmarkt, de decentralisatie van de cao en de zwakte van de vakbeweging, zijn sterke loonstijgingen iets van het verleden en wordt de macht van de vakbeweging bij het leveren van loonmatiging misschien wel overschat. Het belang van coördinatie en samenwerking tussen vakbeweging en werkgevers en hun gezamenlijke opstelling tegenover een steeds minder voorspelbare politieke macht - parlement en regering - ligt elders. In de geleidelijke verandering op de eerdergenoemde terreinen: verbouwing en versobering van de sociale zekerheid, herdefiniëring van arbeids(on)geschiktheid; meer aandacht voor gezondheid en langer doorwerken; meer rechten en gelijkheid voor vrouwen en migranten; betere combinatie van arbeid en zorg, onderwijs en integratie van nieuwe Nederlanders; en verandering van ontslagrecht en bescherming. Kan en wil de vakbeweging dat en willen werkgevers dat samen met de vakbeweging?

De oude stelling van Peter Katzenstein (1985) dat kleine open economieën voor hun succes op de wereldmarkt gebaat zijn bij een krachtig flankerend 
sociaal beleid, doet wellicht nog steeds opgeld. Samen met Zwitserland werd Nederland door Katzenstein destijds gerangschikt onder de liberaalcorporatistische landen, met een zwakke sociaaldemocratie, een verdeelde vakbeweging, veel nadruk op overleg en het zoeken naar consensus, kleine en geleidelijke beleidsaanpassingen, veel aandacht voor de markt en de neiging voorop te lopen in internationalisering (Afonso en Visser, 2014).

De grondslag van onze overlegeconomie zijn de stabiliteit en hoge dekkingsgraad van de collectieve arbeidsovereenkomst (zie ook de bijdrage van Paul de Beer aan deze bundel). Daarin komt namelijk de blijvende wil van werkgevers tot uiting om samen te werken, onderling en met de vakbeweging (ondanks haar geringe representativiteit in veel sectoren). Nederland behoort tot een klein gezelschap van Europese landen met een cao-dekkingsgraad van 80 procent of hoger. Vergelijkend onderzoek laat zien dat dit alleen mogelijk is als de werkgevers georganiseerd zijn en overwegend gezamenlijk over arbeidsvoorwaarden onderhandelen (Visser et al., 2015). Bedrijfstak-cao's, werkgeversorganisatie en algemeenverbindendverklaring zijn de drie institutionele voorwaarden voor een hoge dekkingsgraad. ${ }^{3}$ Het is opmerkelijk en mijns inziens een teken dat de overlegeconomie nog niet weg is, dat de cao met succes de transformatie van economie en arbeidsmarkt heeft overleefd.

De vraag komt op waarom toch de Nederlandse ondernemers, ofschoon de economie in Engelse of Angelsaksische richting is opgeschoven, twintig jaar na Wassenaar niet alsnog gekozen hebben voor Engelse of Angelsaksische arbeidsverhoudingen, protesten tegen de organizing vakbeweging daargelaten. Natuurlijk realiseren werkgevers zich dat ook de vakbeweging leden nodig heeft en dat er alleen dan zaken met de vakbeweging gedaan kunnen worden als deze over het vertrouwen van en de binding met een belangrijke groep werknemers beschikt. Alleen ziet men dat liever gerealiseerd zonder acties, werkonderbrekingen en het roffelen op de loontrommel.

Mijn stelling is dat de werkgevers tot nu toe geen voorstanders zijn geweest van de Angelsaksische of Nieuw-Zeelandse benadering en dat zelfs de erosie van de cao, zoals bij onze oosterburen, is uitgebleven dankzij de geleidelijke en met steun van de vakbeweging uitgevoerde verbouwing van de cao: van een standaard- naar een minimum-cao, met veel meer

3 Zweden en Denemarken zijn de uitzonderingen die de regel bevestigen. Zonder het avvinstrument maar met een hoge organisatiegraad van werknemers en werkgevers wordt in deze landen nog altijd een hoge cao-dekkingsgraad bereikt. Niet-georganiseerde werkgevers tekenen in de meeste gevallen onder dreiging van staking of boycot alsnog een cao waarin ze zich verplichten tot dezelfde minimumvoorwaarden als in de bedrijfstak-cao (Kjellberg, 2012). 
flexibiliteit en ruimte voor individuele (of team-gerelateerde) waardering. Dit staat gelijk aan decentralisatie, niet zozeer in de cao-structuur - het 'marktaandeel' van ondernemings-cao's is eerder gedaald dan gestegen -, maar wel in de cao-inhoud, en met veel meer ruimte voor maatwerk. Op dit punt, wederom, onderscheidt de Nederlandse ontwikkeling zich van de Duitse, waar de verbouwing van de cao is geblokkeerd door een sterke insiderslobby in de industrie binnen vakbeweging en grote ondernemingen, en ook van de Belgische, waar onenigheid binnen en tussen de bonden stelselmatige ingrepen door de staat heeft bevorderd. De vraag is, ten slotte, niet of de Nederlandse vakbeweging veel sterker uit dit proces is gekomen - het lijkt er niet echt op - maar of zij een andere keuze had en of die meer zou hebben opgeleverd. Buitenlandse ervaringen zijn niet erg bemoedigend voor vakbonden die dwars zijn gaan liggen.

\section{Tot slot}

Behaalde successen in het verleden zijn geen garantie voor de toekomst, dat bleek na 200o. Mijn aarzelend bevestigend antwoord op de vraag of de overlegeconomie nog in de wereld van globalisering en Europese integratie past, hangt af van de toekomstige beleidsprestaties van het corporatisme. Als de overlegeconomie, met alle mitsen en maren, bijdraagt aan groei en werkgelegenheid, tweedeling voorkomt, innovatie bevordert en ongelijkheid afremt, dan is zij toekomstbestendig.

In het publieke debat en ook elders in dit boek komt aan de orde dat de organisatorische en politieke voorwaarden voor de overlegeconomie afkalven: machtsverlies van de vakbonden, onbestendigheid en populisme in de politiek, ernstige democratische bedenkingen tegen het corporatistische elitekartel, enzovoorts. Mijn korte en ongenuanceerde antwoord daarop is: ja dat is zo, maar het is niet echt nieuw. De toestand is ernstig, vooral bekeken vanuit de positie van de vakbeweging, maar niet onhoudbaar, en als de overlegeconomie meerwaarde heeft voor Nederland, dan zijn er ook oplossingen voor de genoemde problemen.

Of heeft Wolfgang Streeck (1998, p. 90) gelijk als hij schrijft dat de optimistische 'sociaaldemocratische' visie op de kracht en toekomst van het corporatisme, zoals verwoord in A Dutch Miracle en in dit hoofdstuk, de veranderingen in de internationale economische omgeving en het diepgaand ondermijnende effect van internationale beleidsconcurrentie voor het naoorlogse West-Europese model van arbeidsverhoudingen onderschat? En dat de waarde en onvervangbaarheid van georganiseerde collectieve 
arbeidsverhoudingen en medezeggenschap voor de winstgevendheid van het Rijnlandse stakeholder capitalism en Europese samenwerking in een globale economie worden overschat? Mijn antwoord is dat de huidige fase van globalisering en digitale revolutie nu al zo'n drie decennia oud is en dat het naoorlogse model van arbeidsverhoudingen, aangepast en verbouwd, niettemin zijn wezenlijke trekken heeft behouden; dat collectieve arbeidsverhoudingen en medezeggenschap niet onvervangbaar zijn, of tijdloos, maar wel zo nu en dan hun waarde bewijzen; dat beleidsconcurrentie binnen de Europese Unie van een andere orde is dan beleidsconcurrentie met China; en dat economische samenwerking en sociale beleidsconcurrentie binnen Europees verband ons soort overlegeconomie meestal, hoewel niet altijd, sterker maakt voor de globale concurrentie. 



\title{
4 Afbrokkelende legitimiteit van het poldermodel
}

\author{
Paul de Beer
}

Het poldermodel anno 2016 kan op twee geheel verschillende manieren worden gekarakteriseerd. In de eerste interpretatie is het poldermodel springlevend en vormt het nog altijd de kern van het politiek-bestuurlijke en sociaaleconomische bestel van Nederland. Voordat kabinetten tot politieke besluitvorming op sociaaleconomisch terrein overgaan, vragen zij advies aan de SER of overleggen ze met de sociale partners in de Stichting van de Arbeid. Pas als zij zich hebben vergewist van voldoende draagvlak onder de sociale partners, leggen zij een hervorming voor aan het parlement, dat er dan nauwelijks meer 'nee' tegen kan zeggen. Op decentraal niveau vallen vier van iedere vijf werknemers onder een collectieve arbeidsovereenkomst die door de sociale partners wordt afgesloten, waardoor het overgrote deel van de werkenden deel uitmaakt van het geordende arbeidsbestel.

In de tweede interpretatie staat het poldermodel zwaar onder druk en heeft het zijn langste tijd gehad. De hoofdrolspelers in het poldermodel lijden onder een legitimiteitscrisis. Politici van diverse partijen en maatschappelijke organisaties die zich niet vertegenwoordigd vinden in de polderinstituties, stellen hun legitimiteit regelmatig ter discussie.

Zo schreef VVD-Tweede Kamerlid Anne Mulder in een opinieartikel in Trouw van 5 februari 2015: 'Het feit dat er minder cao's worden afgesloten is niet erg. Want cao's dienen niet het algemeen belang. Cao's dienen het belang van de niet representatieve partijen aan tafel. (...) Voor wie zitten de bonden aan de onderhandelingstafel? Niet voor de jongeren, want het ledenbestand van vakbonden is vergrijsd.' D66-Kamerlid Steven van Weyenberg stelde in Trouw van 23 april 2015: 'Vakbonden houden bij de moeizame CAO-onderhandelingen te vaak vernieuwingen tegen.' Voorzitter Martin Pikaart van de kleine vakbond AVV, die niet vertegenwoordigd is in polderinstituties als de SER en de Stichting van de Arbeid, bekritiseerde in Het Financieele Dagblad van 18 augustus 2015 de gevestigde vakbonden: 'De bestaande belangenbehartiging is echter heel eenzijdig. Je ziet aan de contracten af wie ze gesloten hebben: oudere mannen met vaste dienstverbanden. (...) Een bond als de FNV is niet meer representatief.'

De kritiek richt zich vooral op de vakbonden, die nog slechts iets meer dan een op de zes werknemers als lid hebben. Kritiek op de 
werkgeversorganisaties wordt minder gehoord, enkele uitzonderingen, zoals oud-MKB-voorzitter Hans Biesheuvel, daargelaten. Het verwijt luidt vooral dat de sociale partners de belangen van de insiders behartigen, de oudere werknemers met een vaste baan aan de ene kant en de grote gevestigde ondernemingen aan de andere kant. Hierdoor zouden zij de broodnodige hervorming van de sociale instituties in de weg staan.

Behalve deze zal ik in dit hoofdstuk twee andere ontwikkelingen bespreken die de legitimiteit van het poldermodel onder druk zetten: de sociale partners hebben de afgelopen twee decennia een groot deel van hun verantwoordelijkheid voor de uitvoering van het sociaaleconomisch beleid verloren, en de uitkomsten van het poldermodel, in termen van werkgelegenheid en economische groei, laten steeds meer te wensen over.

Beide interpretaties van het poldermodel, de optimistische en de kritische, zijn op zichzelf correct, maar geven een eenzijdig beeld. Door beide interpretaties - die niet per se strijdig met elkaar zijn - te combineren krijgen we een completer beeld van het functioneren van het model en kunnen we een meer afgewogen oordeel vellen over de overlevingskansen ervan. In deze bijdrage werk ik eerst de eerste, optimistische interpretatie verder uit en schets vervolgens de schaduwzijden van het poldermodel, die in de tweede interpretatie centraal staan. Vervolgens confronteer ik beide interpretaties met elkaar om tot een overkoepelend oordeel over het poldermodel te komen. Tot slot doe ik enkele suggesties hoe de legitimiteitscrisis van het poldermodel zou kunnen worden overwonnen.

\section{De kracht en continuïteit van het poldermodel}

De centrale boodschap van Visser en Hemerijck in A Dutch Miracle (1997) was dat het vermogen en de bereidheid van de betrokken partijen - sociale partners en overheid - tot het leren van eerdere ervaringen in belangrijke mate de (veer)kracht van het Nederlandse overlegmodel bepaalden. Daardoor konden in de jaren 80 en begin jaren 90 ingrijpende hervormingen worden doorgevoerd, die aan de basis lagen van het economische succes in het midden van de jaren 9o. Twintig jaar later is dit punt nog steeds geldig - al is er over de economische opbrengst hiervan meer discussie mogelijk. Na het midden van de jaren go heeft de reeks hervormingen op sociaaleconomisch gebied zich onverminderd voortgezet. En veel van die hervormingen waren weer de uitkomst van overleg en onderhandelingen tussen de overheid en de sociale partners. Om de meest markante hervormingen van de afgelopen twintig jaar te noemen: de invoering van de Wet flexibiliteit en zekerheid 
(vaak kortweg Flexwet genoemd) in 1999, de vervanging van de WAO door de WIA in 2004, de afschaffing van de vut (op basis van de Wet aanpassing fiscale behandeling VUT/prepensioen en introductie Levensloopregeling, oftewel VPL, van 2005), de verhoging van de AOW-leeftijd en herziening van het pensioenstelsel (in gang gezet in 2012), de verkorting van de duur van de WW (in 2015) en de aanpassing van het ontslagrecht in de Wet werk en zekerheid (in 2015).

De meeste van deze hervormingen verliepen allerminst zonder strubbelingen. Vaak ging er zelfs een heftig conflict tussen de vakbeweging en de overheid aan vooraf. Het bekendste voorbeeld is de grote demonstratie op het Museumplein in 2004 over het voornemen van het kabinet om de vut af te schaffen. Maar uiteindelijk gingen de partijen toch weer om de tafel zitten en kwam er een voor alle partijen acceptabel compromis uit de bus. Hoewel overeenstemming met de sociale partners de regering dwingt haar aanvankelijke plannen bij te stellen, is de zekerheid van een breed maatschappelijk draagvlak meestal belangrijker dan dat een plan onverkort kan worden doorgevoerd. Soms vraagt een kabinet eerst advies aan de SER alvorens zelf met een voorstel te komen, zoals bij de hervorming van de WAO, om zo bij voorbaat van voldoende draagvlak verzekerd te zijn. Ook het kabinet-Rutte II, dat kampt met een zwakke parlementaire basis, heeft de vormgeving van zijn sociaaleconomisch beleid in hoge mate afgestemd met de sociale partners in het sociaal akkoord van 2013 (StvdA, 2013). Kortom, de sociale partners zijn de afgelopen twee decennia een hoofdrol blijven spelen in het sociaaleconomisch beleid. Anders gezegd, het Nederlandse sociaaleconomisch beleid is in hoge mate een gezamenlijk product van de overheid, de werkgevers en de vakbonden.

Waarom hechten Nederlandse kabinetten zoveel belang aan draagvlak onder de sociale partners? Volstaat het in een democratische rechtsstaat niet om voor het sociaaleconomisch beleid een parlementaire meerderheid te verwerven en dit beleid vervolgens - voor zover nodig - aan marktpartijen op te leggen? In theorie mag dat zo zijn, in de praktijk is een effectieve uitvoering van sociaaleconomisch beleid mede afhankelijk van de medewerking van de sociale partners. In Nederland bepalen zij immers voor de overgrote meerderheid van de werknemers (rond 80 procent) de arbeidsvoorwaarden in collectieve arbeidsovereenkomsten (cao's). Daarin wordt niet alleen de (initiële) loonsverhoging vastgelegd, maar worden tal van afspraken gemaakt over scholing, bovenwettelijke uitkeringen, arbeidsomstandigheden, pensioenen, et cetera. Overheidsbeleid is beduidend minder effectief indien de sociale partners in cao's afspraken maken om de gevolgen van dat overheidsbeleid te compenseren. Afstemming met de sociale partners biedt 
ook mogelijkheden voor een 'uitruil' met collectieve arbeidsvoorwaarden, bijvoorbeeld loonmatiging in ruil voor lastenverlichting. Aangezien de overheid onmiddellijk profiteert van loonmatiging - doordat ook de loonkosten van overheidspersoneel en de sociale uitkeringen worden gematigd - kan lastenverlichting in dat geval budgetneutraal worden doorgevoerd. Daar komt bij dat arbeidsonrust als reactie op een de vakbonden onwelgevallige overheidsmaatregel economische schade kan veroorzaken.

In dit licht bezien is de afspraak in het sociaal akkoord 2013 over de verkorting van de duur van de WW overigens paradoxaal. Het kabinet wilde de WW-duur verkorten om werklozen te prikkelen om sneller aan het werk te gaan, maar ging er wel mee akkoord dat de sociale partners deze maatregel zouden compenseren door in cao's afspraken te maken over een aanvullende uitkering na afloop van de wettelijke WW. Als deze compensatie daadwerkelijk wordt gerealiseerd, zal de beoogde prikkel van een kortere WW-duur weer ongedaan worden gemaakt. Dat het kabinet dit toch als onderdeel van het sociaal akkoord accepteerde, kan worden verklaard uit het feit dat zij de vakbeweging graag aan het overheidsbeleid committeerde en bovendien met de kortere WW-duur wel een beoogde bezuiniging kon realiseren. Blijkbaar werd dit belangrijker gevonden dan het versterken van de prikkel tot werkhervatting.

Figuur 4.1 Cao-dekkingsgraad 1970-2015 (in \% van de werknemers)

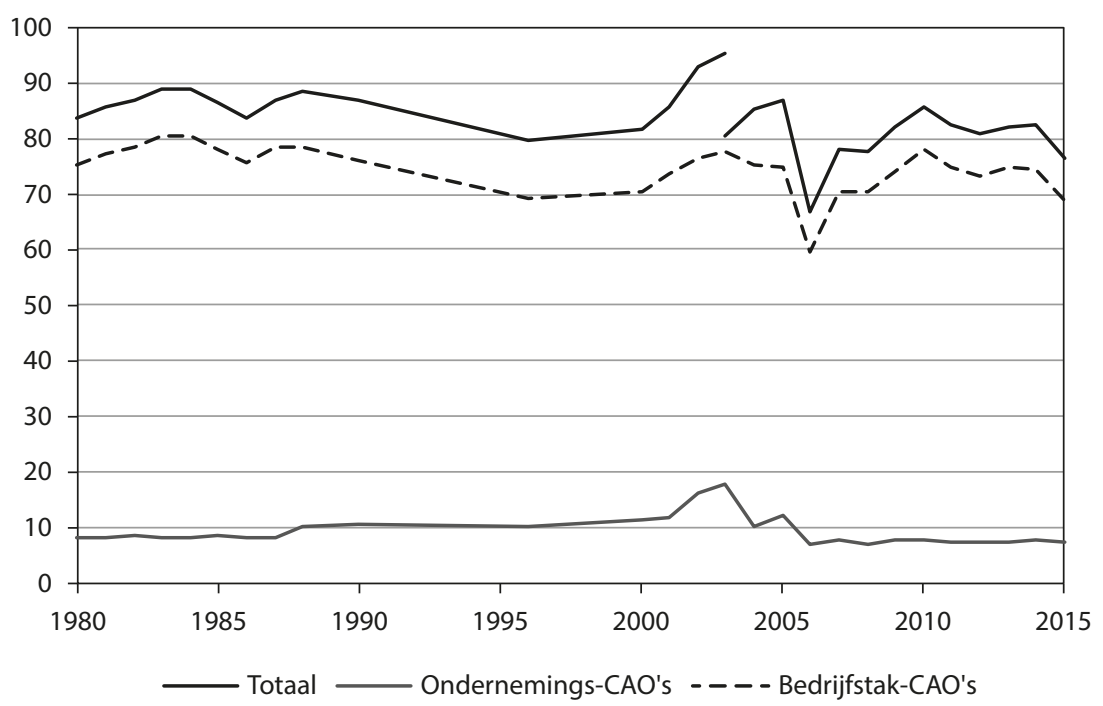

Bron: Ministeries van SZW, CBS (Statline); bewerking door auteur 
De positieve effecten van draagvlak onder de sociale partners staan en vallen echter met de dominante rol die zij hebben op het gebied van de collectieve arbeidsvoorwaarden. Ook op dit terrein is er sprake van een grote mate van continuïteit en stabiliteit in het poldermodel. Ondanks veelvuldige uitspraken over decentralisatie en kritische geluiden over de cao, is er de afgelopen decennia weinig veranderd in het bereik van de cao en de coördinatie van de arbeidsvoorwaarden (zie figuur 4.1 en de bijdrage van Arjen Verhoeff). Het deel van de werknemers dat onder een cao valt - de dekkingsgraad - schommelt al zo'n halve eeuw rond de 80 procent. Anders dan soms wordt verondersteld, heeft zich binnen het cao-bereik ook geen verschuiving voorgedaan van bedrijfstakniveau naar ondernemingsniveau. Het aandeel van de werknemers onder een cao dat onder een bedrijfstak-cao valt, is zelfs toegenomen, van 85 procent in de jaren 70 en 80 naar 91 procent in 2014. In dit opzicht is er dus geen sprake van een decentralisatie van arbeidsvoorwaardenonderhandelingen.

Evenmin zijn er aanwijzingen dat het belang van centrale coördinatie afneemt (zie De Beer, 2013). Dit kan het beste worden vastgesteld aan de hand van de relatie tussen de centrale looneis die de FNV jaarlijks formuleert, en de uitkomst van de cao-onderhandelingen. In de afgelopen twintig jaar kwam de feitelijke stijging van de cao-lonen gemiddeld o, 6 procent per jaar lager uit dan de centrale looneis van de FNV. Dit verschil fluctueert van jaar tot jaar, maar over de periode 1994-2015 vertoont het geen eenduidige stijgende of dalende trend. Wel is het verschil tijdens de huidige crisis groter geworden, maar het is de vraag of dit op een trendbreuk duidt of alleen een conjunctureel effect is. Evenmin is er sprake van een grotere differentiatie in de cao-loonontwikkeling tussen sectoren. De variatiecoëfficiënt van de sectorale cao-loonstijging fluctueerde tussen 1991 en 2015 tussen 0,1 en 0,3, met alleen tussen 1995 en 1997 en in 2014 een uitschieter naar boven. In de periode 1991-2001 was de variatiecoëfficiënt met gemiddeld o,21 vrijwel gelijk aan die in de periode 2002-2015, namelijk 0,22 . De verschillen tussen sectoren in cao-afspraken over de loonstijging nemen dus niet toe. Natuurlijk is de loonontwikkeling slechts een van de arbeidsvoorwaarden in cao's waarover wordt onderhandeld. Ten aanzien van de andere arbeidsvoorwaarden is het niet goed mogelijk een objectief beeld te schetsen van de mate van variatie en differentiatie. Maar a priori is er weinig reden waarom deze arbeidsvoorwaarden sterker uiteen zouden lopen dan bij de loonontwikkeling het geval is.

De dekkingsgraad van cao's wordt meestal uitgedrukt als het percentage van de werknemers dat onder een cao valt. De groei van het aantal zzp'ers, die niet onder een cao vallen, impliceert echter dat het percentage van alle 
Figuur 4.2 Organisatiegraad in \% werknemers en in \% werkzame personen

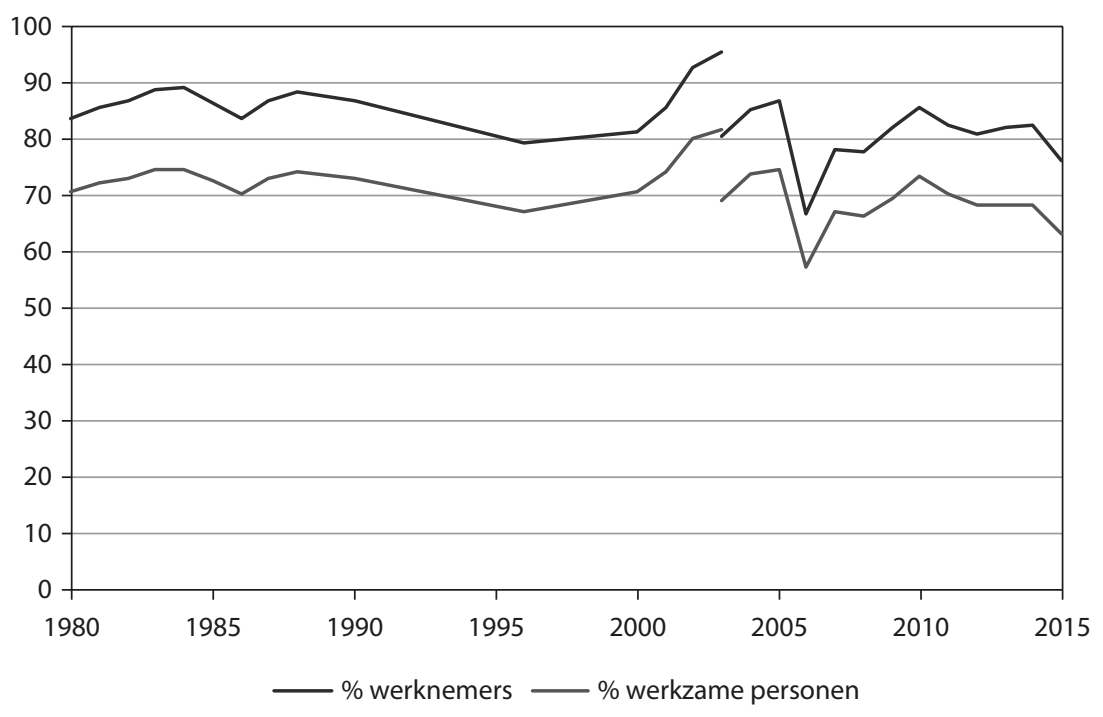

Bron: Ministeries van SZW, CBS (Statline); bewerking door auteur

werkenden dat door een cao wordt gedekt wel degelijk kan afkalven. Als we de cao-dekkingsgraad uitdrukken in procenten van alle werkenden, is hiervoor echter geen aanwijzing (figuur 4.2). De verklaring hiervoor is dat het aandeel zelfstandigen in de werkzame beroepsbevolking decennialang is afgenomen, waardoor de dekkingsgraad in procenten van alle werkenden juist steeg. De recente groei van het aandeel zzp'ers is niet groot genoeg om het beeld voor alle werkenden in de afgelopen drie decennia wezenlijk te veranderen.

\section{De afnemende inputlegitimiteit van het poldermodel}

Dat de feitelijke rol van de sociale partners in het Nederlandse sociaaleconomische bestel nog altijd groot is, betekent niet dat die rol onbetwist is. Integendeel. De legitimiteit van het poldermodel staat steeds meer onder druk. In navolging van Schmidt (2013) onderscheiden we hier tussen input-, throughput- (proces-), en outputlegitimiteit. De inputlegitimiteit betreft vooral de vraag wie de actoren in het poldermodel vertegenwoordigen en in welke mate zij het algemeen belang behartigen. De proceslegitimiteit heeft betrekking op de feitelijke rol die de actoren spelen in het sociaaleconomisch 
beleid. De outputlegitimiteit wordt afgemeten aan de uitkomst: welke resultaten levert het poldermodel op. Zoals Schmidt betoogt, is elke vorm van legitimiteit van belang. Een tekort in de ene vorm kan niet zonder meer worden gecompenseerd door een 'overschot' aan een andere vorm van legitimiteit.

\section{Dalende organisatiegraad van vakbonden}

Ogenschijnlijk staat van deze drie vormen de inputlegitimiteit het meest onder druk. Dat geldt althans voor de positie van de vakbeweging. De vakbonden en de werkgeversorganisaties kunnen, anders dan de regering, hun (input)legitimiteit niet ontlenen aan het feit dat zij langs democratische weg en via participatie van een grote meerderheid van de bevolking zijn gevormd of geselecteerd. De legitimiteit van hun grote rol in het poldermodel moet daarom idealiter voortvloeien uit het feit dat zij brede maatschappelijke belangen vertegenwoordigen, waarin een groot deel van de bevolking zich kan herkennen. Vooral bij de vakbeweging bestaat hierover in toenemende mate twijfel. De belangrijkste reden hiervoor is de afname van de organisatiegraad (het percentage van de werknemers dat lid is van een vakbond). De organisatiegraad van de Nederlandse vakbeweging vertoont al sinds begin jaren 80 een dalende lijn - met overigens een tijdelijke opleving in het midden van de jaren 9o, toen $A$ Dutch Miracle werd geschreven (zie figuur 4.3). Was medio jaren 70 nog een op de drie werknemers in Nederland vakbondslid, sindsdien is dit gehalveerd tot een op de zes. Tegelijkertijd bepaalt de vakbeweging - in cao-onderhandelingen met de werkgevers - voor vier op de vijf werknemers de arbeidsvoorwaarden. Dit betekent grofweg dat voor drie op de vijf werknemers de arbeidsvoorwaarden (mede) door de vakbeweging worden bepaald, terwijl zij geen vakbondslid zijn. ${ }^{1}$

$\mathrm{Nu}$ zegt het aantal leden nog niet alles over de representativiteit van de vakbonden. Als de werknemers die wel vakbondslid zijn een goede afspiegeling zouden vormen van de totale populatie werknemers, dan zou men kunnen betogen dat de vakbonden toch alle werknemers vertegenwoordigen. Tabel 4.1 vergelijkt het aandeel van een aantal groepen in het ledenbestand van de vakbeweging met hun aandeel in de totale populatie van werknemers. Over het geheel genomen zijn de verschillen tussen de

1 Dit geldt indien alle werknemers die vakbondslid zijn onder een cao vallen. Aangezien dit niet het geval is, is het feitelijke aandeel niet-vakbondsleden dat onder een cao valt nog iets groter. 
Figuur 4.3 Organisatiegraad Nederlandse vakbeweging (in \% van de werknemers)

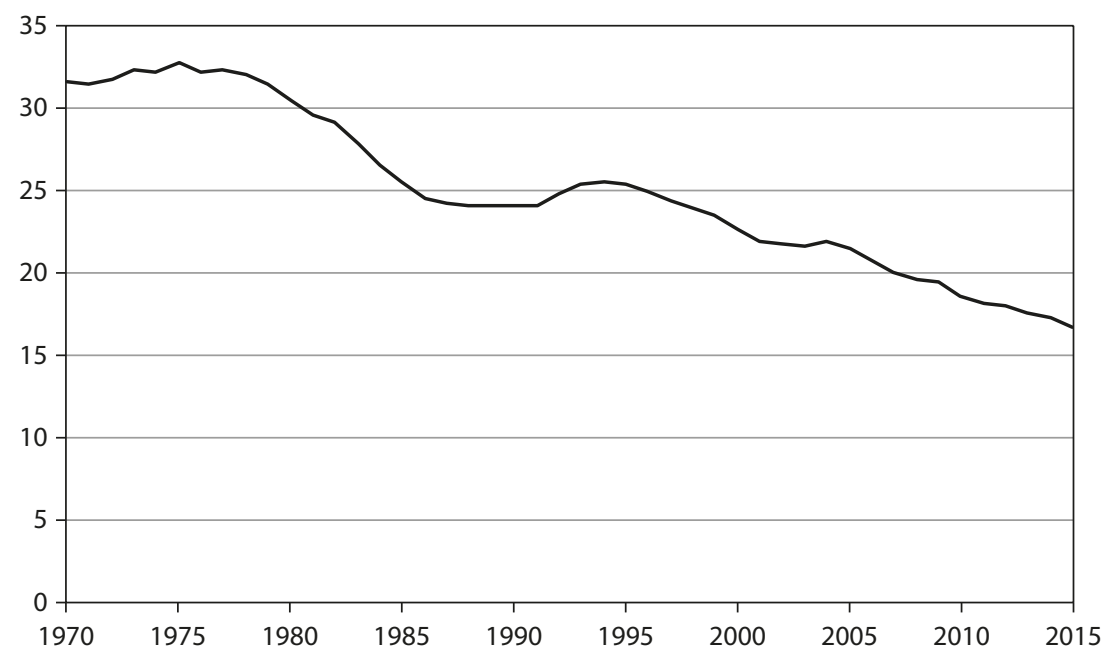

Bron: Visser (2014) en CBS (Statline); bewerking door de auteur

populaties van werknemers en van vakbondsleden niet heel groot. Sommige categorieën zijn echter duidelijk oververtegenwoordigd onder de vakbondsleden; in het bijzonder geldt dit voor $45^{-64}$-jarigen en voor werknemers in het openbaar bestuur en het onderwijs. In iets mindere mate geldt dit ook voor autochtonen, mannen, werknemers met een vaste baan en met een voltijdbaan, werknemers in grotere bedrijven en werknemers in de bouw, vervoer en communicatie. Vaak zijn dit werknemers met een relatief goede en stabiele arbeidsmarktpositie die wel als insiders worden aangeduid. Jongeren, vrouwen, deeltijders en flexwerkers, de outsiders, zijn derhalve ondervertegenwoordigd. Naar opleidingsniveau is het ledenbestand van de vakbeweging wel representatief. Anders dan wel wordt verondersteld, vertegenwoordigen de vakbonden dus niet bij uitstek de laag- of middelbaar opgeleiden.

Tabel 4.1 laat ook zien dat van de meeste groepen die zijn oververtegenwoordigd onder de vakbondsleden, het aandeel onder de werknemers sinds het midden van de jaren 90 is afgenomen, met uitzondering van de ouderen en de werknemers in grote bedrijven. Deze veranderingen in het aandeel van het ledenbestand lopen grotendeels parallel met veranderingen in de samenstelling van de totale populatie werknemers. Naarmate er meer vrouwelijke en oudere werknemers en meer werknemers met een 
flexibele of deeltijdbaan zijn, maken zij ook een groter deel van het aantal vakbondsleden uit.

Om een beter beeld te krijgen van de over- en ondervertegenwoordiging van verschillende groepen werknemers onder het ledenbestand van de vakbeweging, geeft tabel 4.2 de odds ratio's voor het vakbondslidmaatschap van verschillende groepen in 1995 en 2011 . Hierbij wordt steeds de kans dat iemand uit een bepaalde categorie vakbondslid is gedeeld door de kans dat hij/zij geen lid is, vergeleken met een referentiegroep. Zo betekent de odds ratio van 1,49 voor mannen in 2011, dat de kans dat een man in 2011 vakbondslid was gedeeld door de kans dat hij geen lid was anderhalf maal zo groot was als voor vrouwen. Het voordeel van het gebruik van odds ratio's is dat zij niet gevoelig zijn voor het aandeel van een bepaalde groep in de totale populatie. ${ }^{2}$

Tabel 4.1 Kenmerken van werknemers die vakbondslid zijn en van alle werknemers, 1995 en 2011 (\% van totaal)

\begin{tabular}{|c|c|c|c|c|}
\hline & \multicolumn{2}{|c|}{1995} & \multicolumn{2}{|c|}{2011} \\
\hline & vakbondsleden & werknemers & vakbondsleden & werknemers \\
\hline Mannen & 74 & 62 & 61 & 54 \\
\hline 45-64 jaar & 35 & 26 & 57 & 40 \\
\hline Autochtoon & 88 & 84 & 85 & 81 \\
\hline $\begin{array}{l}\text { Middelbaar } \\
\text { opgeleid }\end{array}$ & 43 & 44 & 44 & 43 \\
\hline Vaste arbeidsrelatie & 97 & 91 & 96 & 91 \\
\hline Voltijdbaan & 79 & 72 & 64 & 57 \\
\hline Bouwnijverheid & 9 & 7 & 8 & 5 \\
\hline $\begin{array}{l}\text { Vervoer en } \\
\text { communicatie }\end{array}$ & 10 & 7 & 8 & 6 \\
\hline $\begin{array}{l}\text { Openbaar bestuur } \\
\text { en onderwijs }\end{array}$ & 27 & 17 & 26 & 16 \\
\hline $\begin{array}{l}\text { Bedrijf met } 100 \text { of } \\
\text { meer werknemers }\end{array}$ & 67 & 59 & 78 & 69 \\
\hline
\end{tabular}

Bron: CBS (Statline); bewerking door auteur

2 Dit geldt wel voor een andere voor de hand liggende maat voor de onder- of oververtegenwoordiging van een groep, namelijk het aandeel van die groep onder de vakbondsleden ten opzichte van het aandeel van die groep in de totale populatie. 
Tabel 4.2 Odds ratio's van de kans op vakbondslidmaatschap van werknemers, 1995 en 2011

\begin{tabular}{|c|c|c|}
\hline & 1995 & 2011 \\
\hline vrouwen (referentiegroep) & 1 & 1 \\
\hline mannen & 2.05 & 1.49 \\
\hline 15-24 jaar & 0.48 & 0.32 \\
\hline 25-44 jaar (referentiegroep) & 1 & 1 \\
\hline 45-64 jaar & 1.69 & 2.12 \\
\hline Autochtonen (referentiegroep) & 1 & 1 \\
\hline Westerse allochtonen & 0.79 & 0.79 \\
\hline Niet-westerse allochtonen & 0.59 & 0.68 \\
\hline Lager onderwijs & 1.01 & 1.02 \\
\hline Middelbaar onderwijs (referentiegroep) & 1 & 1 \\
\hline Hoger onderwijs & 1.13 & 0.89 \\
\hline Elementair beroepsniveau & 0.65 & 0.7 \\
\hline Lager beroepsniveau & 0.99 & 0.95 \\
\hline Middelbaar beroepsniveau (referentiegroep) & 1 & 1 \\
\hline Hoger beroepsniveau & 1.1 & 1.01 \\
\hline Wetenschappelijk beroepsniveau & 0.98 & 0.84 \\
\hline Vast dienstverband & 3.8 & 2.85 \\
\hline Flexibel dienstverband (referentiegroep) & 1 & 1 \\
\hline $12-<20$ uur & 0.31 & 0.38 \\
\hline $20-<35$ uur & 0.65 & 0.8 \\
\hline 35 uur of meer & 1 & 1 \\
\hline Landbouw en visserij & 0.48 & 0.44 \\
\hline Energie- en waterleidingbedrijven & 1.81 & 1.42 \\
\hline Industrie (referentiegroep) & 1 & 1 \\
\hline Bouwnijverheid & 1.58 & 1.45 \\
\hline Handel & 0.34 & 0.42 \\
\hline Horeca & 0.41 & 0.25 \\
\hline Vervoer en communicatie & 1.73 & 1.19 \\
\hline Financiële instellingen & 0.62 & 0.51 \\
\hline Zakelijke dienstverlening & 0.38 & 0.39 \\
\hline Openbaar bestuur & 1.98 & 1.62 \\
\hline Onderwijs & 1.68 & 1.36 \\
\hline Gezondheids- en welzijnszorg & 0.73 & 0.74 \\
\hline Cultuur en overige dienstverlening & 0.87 & 0.76 \\
\hline$<10$ werknemers & 0.43 & 0.4 \\
\hline 10-99 werknemers & 0.71 & 0.64 \\
\hline 100 of meer werknemers (referentiegroep) & 1 & 1 \\
\hline
\end{tabular}

Bron: CBS (Statline); bewerking door de auteur 
Tabel 4.2 laat zien dat de oververtegenwoordiging van mannen onder vakbondsleden tussen 1995 en 2011 beduidend is afgenomen. De ondervertegenwoordiging van jongeren en de oververtegenwoordiging van ouderen zijn echter toegenomen. De vergrijzing van het ledenbestand van de vakbeweging is dus niet alleen een gevolg van de vergrijzing van de beroepsbevolking, maar ook van een sterkere daling van de organisatiegraad onder jongeren dan onder ouderen. Onder 15-24-jarige werknemers nam het aandeel vakbondsleden tussen 1995 en 2011 af van 15 naar 6 procent, onder 45-64-jarige werknemers van 38 naar 29 procent. De ondervertegenwoordiging van allochtonen onder de vakbondsleden is weinig veranderd. Opmerkelijk is verder dat de hoger opgeleiden en werknemers met een wetenschappelijk beroep geleidelijk ondervertegenwoordigd raken. In 1995 waren zij nog vrijwel evenredig aan hun aandeel in de werknemerspopulatie vertegenwoordigd onder de vakbondsleden, maar in 2011 zijn zij duidelijk ondervertegenwoordigd. Dit komt doordat de organisatiegraad onder hoogopgeleiden sterker is teruggelopen (van 30 naar 19 procent) dan onder laag- en middelbaar opgeleiden (van 28 naar 21 procent). Hoewel de oververtegenwoordiging van werknemers met een vast contract en een voltijd dienstverband iets is afgenomen, blijft het vakbondslidmaatschap van flexwerkers en deeltijders nog ver bij hen achter.

De verdeling van de vakbondsleden over bedrijfstakken is tussen 1995 en 2011 over het algemeen wat evenwichtiger geworden, al blijven er grote verschillen bestaan tussen de bouwnijverheid, het openbaar bestuur en het onderwijs (met een organisatiegraad van net boven de 30 procent) en de landbouw en visserij, de handel, de horeca, de financiële en de zakelijke dienstverlening (met een organisatiegraad van iets meer dan 10 procent). Vooral in de horeca is de organisatiegraad sterk teruggelopen (van 15 naar 7 procent), waardoor dit nu de minst georganiseerde sector is. Verder is de ondervertegenwoordiging van werknemers in het midden- en kleinbedrijf nog groter geworden.

Samenvattend is het ledenbestand van de vakbeweging tussen 1995 en 2011 vooral naar leeftijd nog minder representatief geworden, maar is de ondervertegenwoordiging van vrouwen wat afgenomen. Voor het overige baart het voor de vakbeweging vooral zorgen dat de organisatiegraad onder hoogopgeleiden en werknemers met een wetenschappelijk beroep het sterkst is afgenomen, terwijl deze groepen een steeds groter aandeel van de beroepsbevolking vormen.

De cijfers in tabel 4.1 en 4.2 betreffen alleen werknemers. Inderdaad maken zij het grootste deel van het ledenbestand van de vakbeweging uit, maar het aandeel niet-werkende leden groeit gestaag. In 2011 vormden de niet-werkenden al 28 procent van het ledental van de vakbeweging. Het gaat 
hierbij voor ruim de helft om gepensioneerden, maar ook om zo'n 200.000 niet-werkzame leden onder 65 jaar, zoals werklozen en arbeidsongeschikten. Hoewel hun invloed binnen de vakbeweging minder groot is dan van de werkende leden, bijvoorbeeld doordat zij niet meepraten of stemmen over (het resultaat van) cao-onderhandelingen, kunnen zij de besluitvorming binnen de vakbeweging toch mede beïnvloeden. In tabel 4.3 wordt daarom de leeftijdsopbouw en de verdeling tussen werkenden en niet-werkenden onder de vakbondsleden vergeleken met de totale bevolking van 15 jaar en ouder.

Tabel 4.3 Samenstelling van vakbondsleden en de bevolking van 15 jaar en ouder, 1995 en 2011 (\% van totaal)

\begin{tabular}{|c|c|c|c|c|}
\hline & \multicolumn{2}{|c|}{1995} & \multicolumn{2}{|c|}{2011} \\
\hline & vakbondsleden & $\begin{array}{c}\text { bevolking } \\
\text { van } 15 \text { jaar en } \\
\text { ouder }\end{array}$ & vakbondsleden & $\begin{array}{l}\text { bevolking van } \\
15 \text { jaar en ouder }\end{array}$ \\
\hline totaal & 100 & 100 & 100 & 100 \\
\hline werknemers & 78 & 43 & 72 & 46 \\
\hline w.v. 15-24 jaar & 6 & 6 & 2 & 5 \\
\hline 25-44 jaar & 45 & 26 & 28 & 23 \\
\hline 45-64 jaar & 27 & 11 & 42 & 18 \\
\hline $\begin{array}{l}\text { niet-werkzaam } \\
<65 \text { jaar }\end{array}$ & 13 & 35 & 12 & 26 \\
\hline $\begin{array}{l}65 \text { jaar en } \\
\text { ouder }\end{array}$ & 9 & 16 & 15 & 19 \\
\hline
\end{tabular}

Bron: CBS; bewerking door de auteur

In 1995 bestond nog net iets meer dan de helft van de vakbondsleden uit werknemers jonger dan 45 jaar. In 2011 vormden zij minder dan een derde van het ledental, slechts iets meer dan het aantal niet-werkende (en voornamelijk oudere) leden. Oudere werknemers (45-plus) en gepensioneerden vormden in 199536 procent van het ledental en in 201157 procent. In kwesties waarin er een belangentegenstelling tussen jongeren en ouderen bestaat, is de balans, qua ledental, in de periode 1995-2011 dus doorgeslagen van een redelijk evenwichtige verdeling naar een ruime meerderheid van oudere werknemers en niet-werkenden.

Een groep die in tabel 4.3 buiten beeld blijft zijn de zelfstandigen zonder personeel (zzp'ers). Zoals bekend is deze groep de afgelopen tien jaar sterk gegroeid, tot inmiddels bijna een miljoen personen (bron: CBS, Statline). Er is verschil van mening in welke mate zij als quasi-werknemers dan wel als zelfstandige ondernemers moeten worden beschouwd, wat het lastig maakt 
wie hun belangen in het poldermodel zou dienen te vertegenwoordigen. Sommige vakbonden richten zich specifiek of mede op de organisatie van zzp'ers (zoals FNV Zelfstandigen, Zelfstandigen Bouw en FNV Kiem), maar het percentage zzp'ers dat hierbij is aangesloten is nog erg klein. Hiernaast zijn er organisaties die zzp'ers in de eerste plaats als ondernemer organiseren, zoals de Stichting ZZP Nederland (met naar eigen zeggen 35.0oo leden) en het Platform Zelfstandige Ondernemers (met 20.00o leden en aangesloten bij VNO-NCW en MKB Nederland). In welke mate deze organisaties representatief zijn voor de zzp'ers en daadwerkelijk de belangen van de meerderheid van de zzp'ers behartigen, is moeilijk vast te stellen.

Een belangrijke vraag is natuurlijk in hoeverre het gebrek aan representativiteit van de vakbeweging zich weerspiegelt in haar standpunten en de belangen die zij behartigt. Publiekelijk springt de vakbeweging in ieder geval regelmatig in de bres voor de belangen van groepen die sterk ondervertegenwoordigd zijn onder haar leden, zoals jongeren en flexwerkers. Voorbeelden daarvan zijn de recente campagne om de minimumjeugdlonen te verhogen, en de strijd tegen wat men als 'doorgeslagen flex' aanduidt. Tegelijkertijd zijn het afgelopen decennium vakbondsonderhandelaars in veel bedrijfstak-cao's akkoord gegaan met clausules die werkgevers meer mogelijkheden bieden om flexibele arbeidskrachten in te zetten dan in de wet was vastgelegd (Schils, 2007; Ministerie van SZW, 2014). Men mag aannemen dat de vakbonden in ruil voor deze concessies aan de werkgevers iets hebben teruggekregen dat waarschijnlijk vooral de insiders ten goede is gekomen. Om te bepalen in welke mate de vakbonden in de praktijk de belangen van hun leden en van niet-leden tegen elkaar afwegen, zou men een diepgravende analyse moeten maken van cao-afspraken, hetgeen het bestek van deze bijdrage te boven gaat. Niettemin is het wel begrijpelijk dat de vergrijzing van het ledenbestand en de oververtegenwoordiging van werknemers met een vast contract twijfels oproepen over de vraag of de vakbeweging de belangen van jongere werknemers en flexwerkers even zwaar laat wegen als die van oudere en vaste werknemers.

\section{Stabiele organisatiegraad aan werkgeverszijde}

Over de representativiteit van de organisaties aan werkgeverszijde is veel minder bekend dan die aan vakbondszijde. Waar het CBS regelmatig cijfers publiceert over het aantal vakbondsleden en hun kenmerken, ontbreken die cijfers volledig ten aanzien van de leden van werkgeversorganisaties. De enige bron die hierin direct inzicht biedt, is de werkgeversenquête van TNO (Oeij et al., 2013). Volgens dit onderzoek onder een steekproef 
van vestigingen van bedrijven en instellingen is 42 procent lid van een werkgevers- of branchevereniging (Oeij et al., 2013, p. 6o). Van de kleine vestigingen (met minder dan vijf werknemers), waartoe veruit de meeste bedrijven en instellingen behoren, is slechts een op de drie lid, van de grote vestigingen met meer dan vijftig werknemers twee op de drie. Doordat het hier om een enquête onder vestigingen gaat, wordt het lidmaatschap waarschijnlijk onderschat doordat vestigingen die deel uitmaken van een groter concern vaak niet zelf lid zullen zijn van een branchevereniging maar het moederbedrijf of het hoofdkantoor wel. Zo is in het onderwijs slechts een op de drie vestigingen lid, terwijl het overgrote deel van de onderwijsinstellingen lid is van een brancheorganisatie. ${ }^{3}$

De meest relevante maatstaf voor de representativiteit van werkgeversorganisaties is echter niet het percentage bedrijven en instellingen dat is aangesloten bij een werkgeversorganisatie, maar het percentage van de werknemers dat in dienst is van een bij een werkgeversorganisatie aangesloten bedrijf of instelling. Dit wordt als de organisatiegraad van werkgevers aangeduid. Hierbij tellen de grotere werkgevers veel zwaarder dan de kleinere werkgevers. Op grond van de cijfers van TNO en CBS-cijfers over de verdeling van werknemers over grootteklassen van bedrijven kunnen we een schatting maken van de totale organisatiegraad (zie tabel 4.4). Deze komt uit op 62 procent, wat betekent dat 62 procent van de werknemers in dienst is van een bedrijf of instelling met een lidmaatschap van een brancheorganisatie of werkgeversvereniging.

Dat de organisatiegraad onder grote bedrijven hoger is dan onder kleine bedrijven, betekent dat het aandeel van de werknemers in grote 'georganiseerde' bedrijven met 68 procent ${ }^{4}$ nog groter is dan het aandeel in alle grote bedrijven $\left(61\right.$ procent $\left.^{5}\right)$. Als de invloed van leden van werkgeversorganisaties evenredig is met hun personeelsomvang, hebben de grotere bedrijven dus een zwaardere stem dan overeenkomt met hun aandeel in de totale werkgelegenheid. Dat de belangen van het midden- en kleinbedrijf in werkgeversorganisaties minder sterk meewegen dan die van grote bedrijven kan ook verklaren dat de al jaren geleden aangekondigde fusie tussen MKB Nederland (de vertegenwoordiger van het midden- en kleinbedrijf) en VNO-NCW (die in sterkere mate de grote bedrijven vertegenwoordigt) traag verloopt en nog altijd niet is voltooid. Hoewel er publiekelijk zelden iets wordt gemeld over onenigheid

3 Zo is 77 procent van het totale aantal besturen in het primair onderwijs, die 92 procent van de leerlingen vertegenwoordigen, aangesloten bij de PO-Raad (PO-Raad, 2014, p. 6).

4 Namelijk 3.324/4.853 x 100\% (tabel 4.4).

5 Namelijk 4.817/7.833 x 100\% (tabel 4.4). 
in werkgeverskring, zijn er niettemin aanwijzingen dat de belangen van het MKB en van het grootbedrijf niet altijd parallel lopen en dat dit soms spanningen in werkgeverskring oproept. Een van de zeldzame keren dat dit naar buiten kwam, was toen MKB-voorzitter Biesheuvel in 2013 aftrad uit onvrede over de wijze waarop VNO-NCW en de brancheorganisaties die bij MKB Nederland zijn aangesloten de belangen van het bedrijfsleven behartigen, en daarop zijn eigen organisatie Ondernemend Nederland (ONL) startte.

Tabel 4.4 Aantal werknemers in bedrijven en instellingen die zijn aangesloten bij een werkgeversorganisatie, 2012

\begin{tabular}{lrrr}
\hline Grootteklasse bedrijf/in- & \% lid werkgevers- \\
stelling (aantal werkzame & $\begin{array}{c}\text { aantal } \\
\text { personen) }\end{array}$ & $\begin{array}{c}\text { werknemers in } \\
\text { verkniging }\end{array}$ & $\begin{array}{c}\text { 'georganiseerde' } \\
\text { bedrijven }\end{array}$ \\
\cline { 3 - 4 } & & $\mathbf{( x ~ 1 . 0 0 0 )}$ & $\mathbf{( x ~ 1 . 0 0 0 )}$ \\
$2-4$ & 34 & 743 & 253 \\
$5-9$ & 46 & 425 & 196 \\
$10-49$ & 55 & 1,274 & 701 \\
$50-99$ & 66 & 575 & 380 \\
$100+$ & 69 & 4,817 & 3,324 \\
totaal & 62 & 7,833 & 4,853 \\
\hline
\end{tabular}

Bron: Oeij (2013), CBS (Statline); bewerking door auteur

Een onder- en bovengrens van de organisatiegraad van werkgevers kan ook worden afgeleid uit de cijfers over de dekkingsgraad van cao's. Het percentage werknemers dat direct onder een bedrijfstak-cao valt (dus niet via de algemeenverbindendverklaring), vormt de ondergrens voor de organisatiegraad van werkgevers. Tellen we hier de werknemers bij op die onder een ondernemings-cao vallen - waarvan niet vaststaat of de werkgever lid is van een brancheorganisatie - dan krijgen we de bovengrens van de organisatiegraad van werkgevers. ${ }^{6}$ Figuur 4.4 toont de ontwikkeling van de onder- en bovengrens sinds 2001. Hieruit blijkt dat de organisatiegraad van werkgevers tussen 60 en 8 o procent ligt, waarschijnlijk in de buurt van 70 procent, hetgeen redelijk in lijn is met de cijfers van TNO, die waarschijnlijk een onderschatting zijn. ${ }^{7}$

6 Hierbij veronderstel ik dat de werkgever van werknemers die niet onder een cao vallen niet bij een brancheorganisatie is aangesloten. Dit hoeft niet juist te zijn, maar als de werkgever wel lid is van een brancheorganisatie heeft deze blijkbaar geen bedrijfstak-cao afgesloten en maakt hij in die zin niet actief deel uit van het poldermodel.

7 Visser (2015) schat de organisatiegraad van werkgevers in Nederland overigens aanzienlijk hoger, namelijk op 85 procent. 
Figuur 4.4 Onder- en bovengrens van de organisatiegraad van werkgevers op basis van dekkingsgraad van cao's (\%)

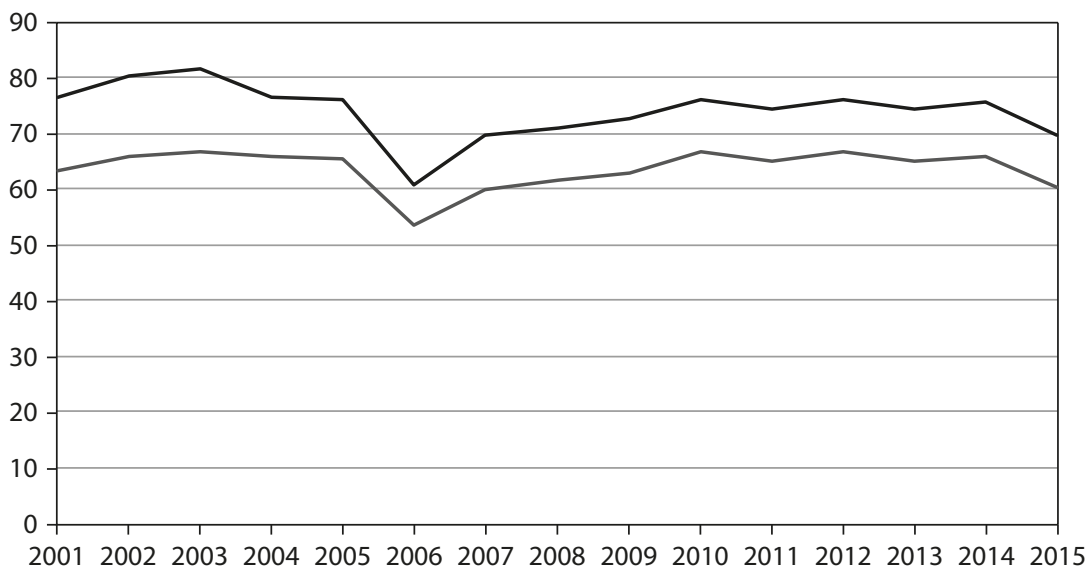

- Ondergrens — Bovengrens

Bron: Min. SZW (2001-2011; 2013-2014), CBS (Statline); bewerking door de auteur

De cijfers in figuur 4 duiden erop dat de organisatiegraad aan werkgeverszijde sinds het begin van deze eeuw redelijk stabiel is. Aan de jaarlijkse schommelingen dient niet veel gewicht te worden toegekend, aangezien die vooral worden bepaald door fluctuaties in het aantal cao's dat is vernieuwd. Er zijn in ieder geval geen aanwijzingen voor een trendmatige daling van de organisatiegraad zoals die zich wel aan werknemerszijde voordoet.

We concluderen dat er, ondanks het feit dat er geen betrouwbare gegevens beschikbaar zijn over de organisatiegraad aan werkgeverszijde, voldoende aanwijzingen zijn dat deze hoog is. Minimaal twee op de drie werknemers werken bij een bedrijf dat georganiseerd is. Daarmee bestaat er geen twijfel over dat de werkgeversorganisaties inderdaad een meerderheid van hun potentiële achterban vertegenwoordigen, althans in termen van werkgelegenheid gemeten. Van de kleinste bedrijven (met minder dan tien medewerkers) is waarschijnlijk echter slechts een minderheid bij een brancheorganisatie aangesloten, zodat het de vraag is of hun belangen altijd voldoende meewegen. Overigens zou men kunnen stellen dat juist het gebrek aan informatie over en aandacht voor de representativiteit van werkgeversorganisaties bijdraagt aan hun inputlegitimiteit, omdat deze suggereren dat er - in tegenstelling tot bij de vakbonden - aan werkgeverszijde geen probleem is. 
Net als bij de vakbonden kan men ook bij werkgeversorganisaties de vraag opwerpen welke belangen zij in de praktijk precies vertegenwoordigen. Terwijl vakbonden regelmatig voor de voeten wordt geworpen dat zij vooral voor de belangen van de insiders opkomen en daarom niet het algemeen belang behartigen, wordt een dergelijk verwijt zelden aan het adres van de werkgevers gericht. Klaarblijkelijk wordt het van werkgeversorganisaties gemakkelijker geaccepteerd dat zij primair het belang van het bedrijfsleven behartigen en niet een breder maatschappelijk belang. Zo stelt de grootste werkgeversorganisatie VNO-NCW op haar website onomwonden: 'VNO-NCW is een lobby-organisatie die zich sterk maakt voor een goed ondernemings- en investeringsklimaat en de gemeenschappelijke belangen van het Nederlandse bedrijfsleven behartigt op zowel nationaal als internationaal niveau. ${ }^{8}$ Ondanks deze relatief smalle focus - zeker in vergelijking met de vakbonden, die juist expliciet aangeven voor een brede doelgroep op te komen ${ }^{9}$ - worden er zelden vraagtekens gezet bij hun rol als gesprekspartner en adviseur (via de SER) van de overheid op tal van andere terreinen - van milieubeleid tot gezondheidszorg.

\section{Hoge opkomst bij verkiezingen, maar matig vertrouwen in de overheid}

Als derde actor in het poldermodel staan we ook kort stil bij de inputlegitimiteit van de overheid. De organisatiegraad, in dit geval gedefinieerd als het ledental van de politieke partijen, lijkt hier geen geschikte maatstaf. Anders dan vakbonden en werkgeversorganisaties ontlenen politieke partijen hun (input)legitimiteit niet aan hun ledental (dat relatief gezien zeer klein is), maar aan het aantal stemmen bij verkiezingen. Men zou daarom de opkomst bij verkiezingen als een indicator kunnen beschouwen voor de inputlegitimiteit van de overheid. Aangezien de opkomst bij Tweede Kamerverkiezingen sinds 1989 tussen 73 en 80 procent schommelt en geen duidelijke trend vertoont, kunnen we stellen dat de inputlegitimiteit van de overheid hoog en stabiel is. Tegelijkertijd is het vertrouwen in politici, politieke partijen en het parlement aan de lage kant. Zij krijgen een rapportcijfer dat rond de 5 ligt, tegenover een 6 voor het rechtssysteem en iets meer voor de politie. Overigens is dit rapportcijfer tussen 2002 en 2012 vrijwel gelijk gebleven (CBS, Statline).

8 http://www.vno-ncw.nl/over_vnoncw/Pages/default.aspx\#.VmrQayiG_DE

9 Zo stelt de FNV op haar website: 'De FNV komt op voor jouw belangen op het gebied van werk en inkomen. Al 1,1 miljoen mensen zijn lid, van scholier tot gepensioneerde.' (www.fnv.nl) 
Uit het continu onderzoek burgerperspectieven (COB) dat het Sociaal en Cultureel Planbureau sinds 2008 ieder kwartaal houdt, blijkt dat het vertrouwen in de regering en de Tweede Kamer rond de 50 procent schommelt. De politiek scoort in dit opzicht overigens beduidend lager dan de vakbonden en de grote ondernemingen, waarin het vertrouwen tussen 60 en 70 procent schommelt (Dekker en Den Ridder, 2014, p. 7). Vooral het relatief grote vertrouwen in de vakbonden duidt erop dat men in dit geval aan de organisatiegraad ook geen al te groot gewicht dient toe te kennen.

\section{Het verdwijnen van de sociale partners uit de beleidsuitvoering}

Volgens Schmidt (2013) heeft throughput-legitimiteit betrekking op wat er gebeurt in de black box van het bestuur (governance). Meer specifiek gaat het om de doeltreffendheid (efficacy), toerekenbaarheid (accountability), openheid (of transparantie) en inclusiviteit van het bestuur.

In dit hoofdstuk zal ik deze aspecten als volgt interpreteren. Bij de doeltreffendheid gaat het primair om de resultaten of uitkomsten van het poldermodel, die ik hierna onder outputlegitimiteit zal bespreken. Bij toereikendheid, openheid en inclusiviteit kan men denken aan de wijze waarop cao-onderhandelingen plaatsvinden of SER-adviezen tot stand komen. Ik wil hier echter de aandacht richten op een ander aspect, dat doorgaans weinig aandacht krijgt in analyses van het poldermodel. Dit aspect betreft de medeverantwoordelijkheid van de sociale partners voor de uitvoering van het sociaaleconomisch beleid in Nederland. Het poldermodel omvat immers niet alleen de besluitvorming over sociaaleconomisch beleid, maar ook de uitvoering ervan. Er valt veel voor te zeggen dat beide onlosmakelijk met elkaar verbonden zijn. Streeck en Schmitter (1985) wezen al op de voordelen om in een corporatistisch systeem de uitvoering van het beleid, waarover de non-gouvernementele actoren (in dit geval de sociale partners) en de overheid overeenstemming hebben bereikt, aan de sociale partners te delegeren:

'[T] he agents of implementation - the professional staff and the officials of the association [lees: de vakbond of werkgeversorganisatie - PdB] - are closer to the target group (their members) than state bureaucracies, and they have more intimate knowledge of its situation and concerns. It is likely that this enables them to apply rules less formalistically and to take the specific conditions of individual cases better into account - which, in turn, tends to increase the acceptance of regulation by those affected by it' (Streeck \& Schmitter, 1985, p. 132; zie ook Lehmbruch, 1977). 
Bovendien kunnen de sociale partners het draagvlak voor het beleid vergroten door specifieke argumenten aan te voeren die hun achterban aanspreken, terwijl de overheid alleen algemene argumenten kan gebruiken.

Delegatie van verantwoordelijkheden voor de uitvoering van het sociaaleconomisch beleid aan de sociale partners kan dus bijdragen aan zowel de legitimiteit als de effectiviteit van het beleid. In het verleden speelden de sociale partners in Nederland inderdaad een grote rol bij de uitvoering van het sociaaleconomisch beleid. Bij de opbouw en uitbouw van de verzorgingsstaat na de Tweede Wereldoorlog werd besloten - vooral op aandrang van de christendemocraten - om de uitvoering grotendeels aan het maatschappelijk middenveld te delegeren. Dit resulteerde in het typische verzuilde Nederlandse landschap met katholieke, protestants-christelijke, sociaaldemocratische en soms 'neutrale' (of liberale) woningbouwcorporaties, ziekenfondsen, onderwijsinstellingen, ziekenhuizen, zorginstellingen, omroepen, sportverenigingen, et cetera. Ook op sociaaleconomisch gebied, in het bijzonder de sociale verzekeringen, werd de uitvoering overgedragen aan het maatschappelijk middenveld, zij het niet in verzuilde organisaties maar in sectorale organisaties en overkoepelende nationale organisaties. Zo vormden vertegenwoordigers van de vakbonden en de werkgeversorganisaties de besturen van de sectorale bedrijfsverenigingen die de werknemersverzekeringen (WW, ZW, WAO) uitvoerden. Daarnaast waren zij vertegenwoordigd in het bestuur van de Sociale Verzekeringsbank die de volksverzekeringen (AOW, AWW en AKW) uitvoerde. De sociale partners bestuurden ook de publiekrechtelijke bedrijfsorganisaties (PBO's), de bedrijfschappen en productschappen - waaraan aanvankelijk een grote rol bij de wederopbouw en de besturing van de Nederlandse economie werd toebedacht - en de Kamers van Koophandel.

Deze delegatie van de uitvoering van belangrijke onderdelen van het sociaaleconomisch beleid aan (mede) door de sociale partners bestuurde organisaties schiep een directe band tussen de centrale vormgeving van het beleid en de decentrale uitvoering. De (mede)verantwoordelijkheid van de sociale partners voor de uitvoering van het beleid maakte het min of meer vanzelfsprekend om hen direct te betrekken bij de formulering van het beleid. Hiermee vergrootte de overheid immers de kans dat zij het beleid loyaal zouden uitvoeren. Omgekeerd kon de overheid bij beleidswijzigingen dankbaar gebruikmaken van de kennis en ervaring die de sociale partners bij de uitvoering hadden opgedaan. Dat vergrootte de kans dat beleidswijzigingen ook in de praktijk effectief zouden blijken.

In de jaren go rees echter twijfel of de sociale partners hun uitvoerende taak wel naar behoren uitvoerden. Mede door een soepele toepassing van de 
toekenningscriteria door de sociale partners nam het gebruik van de sociale zekerheid in de jaren 80 explosief toe. Dit gold met name voor het grote aantal werknemers dat een arbeidsongeschiktheidsuitkering krachtens de WAO ontving, doordat de sociale partners deze sociale verzekering in de jaren 80 - overigens met instemming van de overheid - gebruikten als een genereuze afvloeiingsregeling voor overtollige werknemers.

Met de bekende uitspraak 'Nederland is ziek' kondigde premier Lubbers in 1990 drastische wijzigingen in de sociale zekerheid aan. Naast forse ingrepen in de regelingen zelf (de z.g. materiewetgeving), nam ook de (politieke) druk toe om de wijze van uitvoering te wijzigen. De parlementaire enquête naar de uitvoering van de socialeverzekeringswetten onder leiding van Flip Buurmeijer in 1993 vormde hierin een keerpunt. De commissie-Buurmeijer constateerde dat de door de sociale partners bestuurde bedrijfsverenigingen ernstig tekortschoten in de uitvoering van hun taak doordat zij onvoldoende waren gericht op het voorkomen van instroom in en het bevorderen van uitstroom uit de regelingen.

De uitkomst van de enquête werd alom geïnterpreteerd als een motie van wantrouwen ten aanzien van de rol van de sociale partners in de uitvoering van de sociale zekerheid. Hierdoor ontstond er steeds meer politieke steun voor de gedachte dat de sociale partners hun verantwoordelijkheid voor de uitvoering van de sociale zekerheid moesten opgeven. De meningen over het alternatiefliepen echter ver uiteen. Sommigen pleitten voor privatisering van de uitvoering door deze uit te besteden aan marktpartijen, andere pleitten juist voor een sterkere rol van de overheid. Het eerste sociaaldemocratischliberale kabinet-Kok stevende aanvankelijk af op een combinatie: publieke claimbeoordeling en toezicht en private uitvoering. Over de uitwerking hiervan ontstond echter zoveel onenigheid, dat het kabinet er niet uitkwam en het volgende kabinet (Kok II) in 1999 uiteindelijk een voorstel naar de Tweede Kamer stuurde om de uitvoering geheel in publieke handen te leggen. Dit resulteerde in de Wet SUWI van 2001 en de oprichting van het UWV, waarmee de sociale partners hun positie in de sociale zekerheid volledig kwijtraakten (zie voor een uitvoerige analyse Van Gestel et al., 20o9, hoofdstuk 5 en 6). De sociale verzekeringen werden hiermee geheel een overheidsverantwoordelijkheid. Alleen in de sfeer van de aanvullende sociale zekerheid - bovenwettelijke uitkeringen en pensioenen - behielden de sociale partners hun dominante positie.

Opmerkelijk is dat begin jaren 9o, toen de kritiek op de rol van de sociale partners in de sociale zekerheid aanzwol, aan hen wel een belangrijke nieuwe rol werd toegekend in de besturen van de arbeidsvoorziening (de zogenaamde 'tripartisering'). De gezamenlijke verantwoordelijkheid van 
sociale partners en (lokale) overheid voor de arbeidsvoorziening kwam echter nooit goed van de grond. Na een zeer kritische evaluatie door de commissie-Van Dijk in 1995 werd hieraan, vóór de jaren 90 voorbij waren, alweer een einde gemaakt. Uiteindelijk zou de arbeidsvoorziening, via de tussenfase van de Centra voor Werk en Inkomen (CWI's) zelfs geheel opgaan in de zuiver publieke uitvoeringsorganisatie voor de werknemersverzekeringen, het UWV (zie hierover uitgebreider Van Gestel et al., 2009, hoofdstuk 5).

Tot slot zijn in 2015 ook de laatste bedrijf- en productschappen opgeheven, waarmee na 65 jaar ook een einde is gekomen aan de gezamenlijke verantwoordelijkheid van de sociale partners voor het sectorale economisch beleid.

Door het verdwijnen van de sociale partners uit het grootste deel van de uitvoering van de sociale zekerheid en het arbeidsmarktbeleid is een veel scherpere scheiding aangebracht tussen de verantwoordelijkheden van de overheid en die van de sociale partners. Dit heeft weliswaar meer duidelijkheid gecreëerd, maar het heeft ook meer afstand geschapen tussen de sfeer van het sociaaleconomisch overheidsbeleid en het arbeidsvoorwaardenbeleid van de sociale partners. Op centraal niveau kunnen beide nog wel met elkaar worden verbonden in centrale afspraken of sociale akkoorden (bijvoorbeeld als er een 'uitruil' plaatsvindt tussen loonmatiging en lastenverlichting), maar op decentraal niveau, in de uitvoering, staan zij los van elkaar. Daar komt nog bij dat het arbeidsvoorwaardenbeleid vooral sectoraal wordt vormgegeven, terwijl het arbeidsmarktbeleid juist regionaal wordt uitgevoerd, zeker na de grote decentralisatieoperatie die het kabinet in 2015 heeft doorgevoerd. Dit bemoeilijkt de afstemming tussen arbeidsvoorwaardenbeleid en sociaaleconomisch beleid.

Waarschijnlijk gaat dit ten koste van de effectiviteit van het beleid. Aangezien zowel het overheidsbeleid als het arbeidsvoorwaardenbeleid een belangrijke invloed uitoefenen op de sociaaleconomische prestaties, bijvoorbeeld in termen van werkgelegenheid, inkomensontwikkeling en economische groei, valt er winst te behalen door beide op elkaar af te stemmen. Ontbreekt deze afstemming en streven de sociale partners en de overheid deels tegengestelde doelen na, dan kunnen zij proberen de effecten van elkaars beleid ongedaan te maken, waardoor de uitkomst voor geen van de partijen optimaal is.

Omgekeerd roept de scheiding van verantwoordelijkheden ook vragen op over de legitimiteit van de grote rol van de sociale partners in de formulering van het sociaaleconomisch beleid. Als het arbeidsvoorwaardenbeleid en (de uitvoering van) het sociaaleconomisch beleid los van elkaar staan, dan vormt de dominante rol van de sociale partners op het gebied van de arbeidsvoorwaarden ook geen legitimering meer van hun rol op centraal 
niveau. Het genoemde voorbeeld van de verkorting van de WW vormt daarvan een illustratie: waarom zouden de sociale partners moeten meebeslissen over een hervorming van de WW als zij die vervolgens op cao-niveau weer ongedaan (proberen te) maken?

\section{Tanende outputlegitimiteit}

De faam van het poldermodel ten tijde van A Dutch Miracle moet in de eerste plaats worden verklaard uit de goede sociaaleconomische prestaties van Nederland in het midden van de jaren 9o. Tot halverwege de jaren 90 stond het corporatistische systeem in Nederland zelf juist regelmatig aan stevige kritiek bloot. Zo constateerde de Volkskrant op 12 maart 1994 in een artikel met de kop 'Een onderaardse rustkamer': 'Na bijna een jaar vruchteloos bakkeleien is de Sociaal-Economische Raad er niet in geslaagd om voor de komende kabinetsjaren een eensluidend advies uit te brengen. Het is de zoveelste nagel in de doodskist van een adviesorgaan, dat sinds enkele jaren zwaar onder vuur ligt.' Economen van naam, zoals Sweder van Wijnbergen, Eduard Bomhoff en Gerrit Zalm (destijds directeur van het Centraal Planbureau), bekritiseerden regelmatig de stroperigheid, het gebrek aan hervormingsbereidheid en de bevoordeling van de insiders als gevolg van het Nederlandse overlegmodel (De Beer, 2000). In 1995 schrapte de Tweede Kamer zelfs de plicht van het kabinet om voor belangrijke sociaaleconomische kwesties advies aan de SER te vragen.

In dezelfde periode maakte de Europese economie een recessie door en liep de werkloosheid in veel EU-lidstaten fors op. In Nederland bleef de werkloosheid echter relatief laag en groeide de werkgelegenheid gestaag door. Tegelijkertijd slaagde de overheid erin het financieringstekort sterk terug te dringen, onder meer door de sociale zekerheid te hervormen. Pas toen deze goede prestaties internationaal de aandacht trokken, werd ook in Nederland een verband gelegd met het overlegmodel en werd de term poldermodel geïntroduceerd. Hoewel Visser en Hemerijck deze term in hun boek met opzet meden omdat er naar hun mening niet van een welbewust ontworpen 'model' sprake was, werd en wordt $A$ Dutch Miracle toch alom gezien als een poging om het succes van het poldermodel te verklaren.

Als de sociaaleconomische prestaties in de jaren 90 zo belangrijk waren voor de populariteit van het poldermodel, dan ligt het voor de hand om ook twee decennia later het Nederlandse overlegmodel mede te beoordelen op basis van de uitkomsten op sociaaleconomisch terrein: in termen van Schmidt (2013) de outputlegitimiteit. Ik vergelijk daartoe de Nederlandse 
prestaties in drie opeenvolgende decennia (1983-1993, 1993-2003 en 2003-2013) op een aantal indicatoren met een vijftal omringende landen, te weten België, Duitsland, Frankrijk, Denemarken en het Verenigd Koninkrijk (tabel 4.5). Het eerste decennium betreft de tien jaar na het befaamde Akkoord van Wassenaar in november 1982, dat veelal wordt beschouwd als de bakermat van het latere succes van het Nederlandse overlegmodel. Het tweede decennium vormt de hoogtijdagen van het poldermodel, toen het internationaal naam en faam verwierf. Het derde decennium is de meest recente periode, waarin Nederland, zoals we zullen zien, weer een deel van zijn voorsprong verspeelde.

Ik richt me op een aantal indicatoren die veelvuldig als maatstaven voor het sociaaleconomisch presteren van landen worden gehanteerd: het tempo van economische groei (per hoofd van de bevolking om een correcte maatstaf voor welvaartsgroei te krijgen), de arbeidsproductiviteit (per gewerkt uur) en de werkgelegenheidsgroei. Daarnaast neem ik de ontwikkeling van de reële loonkosten per uur op als indicator voor het belang van loon(kosten) matiging. Uiteraard zijn er andere maatstaven denkbaar om de sociaaleconomische prestaties van landen aan af te meten (denk aan de groei van het arbeidsvolume in uren of de inkomensongelijkheid), maar niet alleen ontbreekt het daarbij vaak aan consistente tijdreeksen over een langere periode, er bestaat ook minder consensus over het belang ervan. (Is een groter arbeidsvolume een doel per se? Is minder ongelijkheid altijd beter?)

Ten tijde van het Akkoord van Wassenaar kende Nederland op België na de laagste werkgelegenheidsgraad en het hoogste werkloosheidspercentage van deze groep van zes landen. Dat verklaart waarom in de jaren 80 vaak gesproken werd over de Dutch disease. In de tien daaropvolgende jaren groeide de werkgelegenheid in Nederland echter in een tempo dat minimaal het dubbele was van dat van de andere landen, waardoor de werkloosheid in 1993 was gedaald tot het laagste percentage van de zes landen. Ook de werkgelegenheidsgraad steeg aanzienlijk, al was Nederland in 1993 nog een middenmoter. De sterke werkgelegenheidsgroei was niet zozeer het gevolg van een bijzonder sterke economische groei - die was vergelijkbaar met die van de andere landen - maar vooral van een gematigde productiviteitsstijging. Anders gezegd, de Nederlandse groei was zeer arbeidsintensief. Dit wordt doorgaans verklaard uit de zeer gematigde loonkostenstijging - een van de centrale elementen van het Akkoord van Wassenaar - die de druk op werkgevers om te investeren in arbeidsbesparende technologie verminderde. Daarnaast speelde de sterke groei van deeltijdbanen een rol, waardoor een gegeven arbeidsvolume over meer personen werd verdeeld.

In het tweede decennium, 1993-2003, wist Nederland deze prestaties te continueren, waarmee het poldermodel internationale faam verwierf. De 
Tabel 4.5 Prestaties van Nederland vergeleken met vijf omringende landen, 19832013

\begin{tabular}{|c|c|c|c|c|c|c|}
\hline & Nederland & België & Frankrijk & Duitsland & Denemarken & $\begin{array}{r}\text { Verenigd } \\
\text { Koninkrijk }\end{array}$ \\
\hline \multicolumn{7}{|l|}{ jaarlijkse mutaties (\%) } \\
\hline \multicolumn{7}{|l|}{ 1983-1993 } \\
\hline bbp per capita & 2,1 & 2 & 1,7 & 2,4 & 1,7 & 2,3 \\
\hline $\begin{array}{l}\text { productiviteit per } \\
\text { gewerkt uur }\end{array}$ & 1,5 & 2,2 & 2,2 & 2,9 & 2,7 & 2,5 \\
\hline werkgelegenheid & 1,9 & 0,5 & 0,5 & 0,8 & 0,7 & 0,7 \\
\hline loonkosten per uur & $-0,1$ & 1,8 & 0,8 & 2,1 & 1,6 & 1,6 \\
\hline \multicolumn{7}{|l|}{ 1993-2003 } \\
\hline bbp per capita & 2,2 & 2,1 & 1,8 & 1,3 & 2,1 & 2,8 \\
\hline $\begin{array}{l}\text { productiviteit per } \\
\text { gewerkt uur }\end{array}$ & 1,3 & 1,2 & 2 & 1,9 & 1,6 & 2,7 \\
\hline werkgelegenheid & 2 & 0,9 & 1 & $-0,2$ & 0,5 & 1 \\
\hline loonkosten per uur & 0,9 & 0,3 & 0,6 & 0,1 & 0,9 & 2,2 \\
\hline \multicolumn{7}{|l|}{ 2003-2013 } \\
\hline bbp per capita & 0,8 & 0,7 & 0,5 & 1,3 & 0,1 & 0,5 \\
\hline $\begin{array}{l}\text { productiviteit per } \\
\text { gewerkt uur }\end{array}$ & 0,7 & 0,4 & 0,6 & 0,9 & 0,8 & 0,6 \\
\hline werkgelegenheid & 0,3 & 1,1 & 0,3 & 1,2 & $-0,1$ & 0,7 \\
\hline loonkosten per uur & 0 & 0,3 & 0 & $-0,6$ & 0,6 & 0,6 \\
\hline \multicolumn{7}{|l|}{ niveaus (\%) } \\
\hline \multicolumn{7}{|l|}{$\begin{array}{l}\text { werkgelegenheids- } \\
\text { graad }\end{array}$} \\
\hline 1983 & 56,8 & 54,6 & 61,4 & 62,2 & 72,2 & 64,3 \\
\hline 1993 & 63,7 & 56,3 & 61,4 & 65,7 & 74,3 & 67,5 \\
\hline 2003 & 74,4 & 60,3 & 65,2 & 65,1 & 76,4 & 71,1 \\
\hline 2013 & 75,9 & 62,4 & 65,2 & 74,6 & 74,9 & 72,6 \\
\hline \multicolumn{7}{|l|}{$\begin{array}{l}\text { werkloosheidsper- } \\
\text { centage }\end{array}$} \\
\hline 1983 & 11,9 & 13,5 & 7,2 & 8 & 9,7 & 11,4 \\
\hline 1993 & 6,3 & 12,1 & 9,7 & 8 & 10,7 & 10,3 \\
\hline 2003 & 3,6 & 8,2 & 8 & 9,3 & 5,4 & 4,9 \\
\hline 2013 & 6,7 & 8,4 & 9,7 & 5,3 & 7 & 7,7 \\
\hline
\end{tabular}

Bbp per capita $=$ het reële bbp per hoofd van de bevolking op basis van koopkrachtpariteiten Productiviteit per gewerkt uur $=$ het reële bbp per gewerkt uur.

Werkgelegenheidsgraad = werkgelegenheid in personen als percentage van de bevolking van 15-64 jaar.

Bron: OECD Statistics, Eurostat, The Conference Board; bewerking door de auteur 
werkgelegenheidsgroei zette zich onverminderd voort, hoewel het tempo van economische groei nog steeds niet uitzonderlijk was. Dit was opnieuw het resultaat van een trage productiviteitsgroei, hoewel Nederland zich in deze periode niet meer van de andere landen onderscheidde in loonkostenmatiging. Dat recept was inmiddels ook door de andere landen ontdekt, wat ook in die landen gepaard ging met een matige productiviteitsstijging die bijdroeg aan herstel van de werkgelegenheid. Na twintig jaar van sterke werkgelegenheidsgroei had Nederland in 2003 op Denemarken na de hoogste werkgelegenheidsgraad van deze zes landen en de laagste werkloosheid.

In het derde decennium, 2003-2013, viel de economische groei in alle zes landen sterk terug als gevolg van de grote recessie die in 2009 aanving. Alleen Duitsland wist zich aan de malaise te onttrekken. De economische crisis had vanzelfsprekend haar weerslag op de werkgelegenheid, maar opmerkelijk is dat dit voor Nederland in sterkere mate gold dan voor de andere landen behalve Frankrijk en Denemarken. Dit heeft te maken met het feit dat de productiviteitsstijging in die landen (met uitzondering van Duitsland) lager lag dan in Nederland, waardoor de geringe economische groei daar meer banen genereerde. Wat in belangrijke mate het succes van Nederland in de twee voorgaande decennia verklaarde - de arbeidsintensieve groei als gevolg van loonkostenmatiging en een geringe productiviteitsstijging - bleek nu de verklaring voor de iets sterkere werkgelegenheidsgroei in België, Duitsland en tot op zekere hoogte het VK. Hoewel de werkgelegenheidsgraad in Nederland in het laatste decennium nog wel iets verder steeg (maar na 2008 weer daalde) en op dit punt zelfs Denemarken passeerde, kwamen België en vooral Duitsland dichterbij. Tegelijkertijd steeg de werkloosheid in Nederland in deze periode sterker dan in de andere landen, waardoor Nederland zich op dit punt in 2013 nog maar weinig onderscheidde van de andere landen (m.u.v. Frankrijk) en Duitsland inmiddels voor moest laten gaan.

Anders gezegd, Nederland wist zijn goede positie op het gebied van werkgelegenheid en werkloosheid in het afgelopen decennium weliswaar te consolideren, maar zag een aantal andere landen dichterbij komen. De banenmotor - toch de belangrijkste prestatie waaraan het Dutch Miracle in de jaren 90 zijn faam ontleende - is de afgelopen tien jaar bijna stilgevallen. Daarmee lijkt een einde te zijn gekomen aan het Nederlandse werkgelegenheidswonder.

Deels komt dit doordat ook andere landen het 'geheim' van de loonmatiging hebben ontdekt. Deels heeft het te maken met het feit dat de werkgelegenheidsgraad in Nederland al zo hoog is en de werkloosheid voor het uitbreken van de crisis zo laag was, dat het steeds moeilijker is 
verdere verbetering te realiseren. Het feit dat Denemarken, dat lange tijd de hoogste werkgelegenheidsgraad in de EU had, de afgelopen tien jaar nog matiger presteerde, is daarmee in overeenstemming. De geijkte Nederlandse instrumenten lijken uitgewerkt en daarmee komt ook de outputlegitimiteit van het poldermodel onder druk te staan.

\section{Tussenbalans}

Elk van de drie vormen van legitimiteit die Schmidt (2013) onderscheidt, staat in het poldermodel onder druk. De inputlegitimiteit erodeert doordat de organisatiegraad van de vakbeweging steeds verder afkalft en het overblijvende ledenbestand vooral qua leeftijd steeds minder representatief is voor de beroepsbevolking. Compensatie hiervoor wordt wel geboden door de, voor zover bekend, hoge en stabiele organisatiegraad aan werkgeverszijde. De proceslegitimiteit is verminderd doordat de sociale partners de afgelopen vijftien jaar een groot deel van hun rol in de uitvoering van het sociaaleconomisch beleid zijn kwijtgeraakt. Doordat zij geen positie meer hebben in de uitvoering van de werknemersverzekeringen en de arbeidsvoorziening is de band tussen hun medeverantwoordelijkheid voor de vormgeving van het sociaaleconomisch beleid en de uitvoering van dit beleid veel losser geworden. Dit vermindert zowel de legitimiteit van hun rol bij de vormgeving van het beleid als de effectiviteit ervan, doordat het arbeidsvoorwaardenbeleid van de sociale partners en het sociaaleconomisch beleid van de overheid onvoldoende op elkaar worden afgestemd. Tot slot staat ook de outputlegitimiteit onder druk. Weliswaar behoort Nederland qua werkgelegenheidsgraad en werkloosheidspeil nog tot de best presterende landen in de EU, maar de laatste tien jaar heeft Nederland pas op de plaats gemaakt en is de voorsprong op een aantal andere landen, zoals België en Duitsland, geslonken. Het poldermodel kan zijn legitimiteit dus steeds minder ontlenen aan het feit dat het beter presteert dan andere landen.

\section{Een nieuwe koers?}

Om te waarborgen dat er voor het Nederlandse overlegmodel ook op langere termijn voldoende maatschappelijk draagvlak blijft, zouden bij voorkeur alle drie besproken vormen van legitimiteit - input-, proces- en outputlegitimiteit - moeten worden versterkt. Het versterken van de inputlegitimiteit, althans voor zover het de organisatiegraad en representativiteit van de 
vakbeweging betreft, lijkt nog de lastigste opgave, aangezien de afname hiervan geen typisch Nederlands verschijnsel is maar zich in vrijwel alle Europese landen voordoet. Ik kom hier aan het eind op terug, maar richt mij eerst op de proces- en outputlegitimiteit en met name de relatie tussen beide.

De afname van de verantwoordelijkheid van de sociale partners voor de uitvoering van het sociaaleconomisch beleid en daarmee de proceslegitimiteit maakt het ook lastig om de outputlegitimiteit, in het bijzonder ten aanzien van de werkgelegenheidsgraad, te versterken. De sterke stijging van de werkgelegenheidsgraad in de afgelopen decennia was vooral te danken aan de snelle opmars van vrouwen op de arbeidsmarkt en de stijging van de arbeidsdeelname van ouderen. Deze waren mede het gevolg van afspraken tussen de sociale partners over de bevordering van deeltijdwerk en het stapsgewijs afschaffen van regelingen voor vervroegde uittreding (vut). Om de werkgelegenheidsgraad nog verder te kunnen verhogen zal vooral de arbeidsparticipatie van kwetsbare groepen met een grotere afstand tot de arbeidsmarkt moeten worden gestimuleerd. Het gaat hierbij onder meer om arbeidsbeperkten en langdurig werklozen. Deze groepen zijn niet direct gebaat bij een algehele werkgelegenheidsgroei, maar vragen om een specifiekere aanpak. Dit vraagt om beleid op het raakvlak van sociale zekerheid, arbeidsmarktbeleid en cao-beleid, zoals het scheppen van stage- en leerwerkplekken of aangepaste arbeidsplaatsen voor mensen met een arbeidsbeperking. Zoals hierboven uiteengezet, zijn de verantwoordelijkheden voor deze beleidsterreinen in de afgelopen vijftien jaar gescheiden, waardoor de afstemming is bemoeilijkt.

In het sociaal akkoord van april 2013 spraken de sociale partners en de regering echter af om op het terrein van de WW en het arbeidsmarktbeleid de verantwoordelijkheid van de sociale partners weer te versterken. Volgens het sociaal akkoord:

'willen sociale partners een herschikking van de publieke en private (wettelijke en bovenwettelijke) verantwoordelijkheden met betrekking tot de WW. Deze herschikking heeft betrekking op zowel de regie en de financiering van de WW (en andere werknemersverzekeringen) als op de polisvoorwaarden (in het bijzonder de uitkeringsduur en -opbouw) (StvdA, 2013, p. 17, 18).'

'Sociale partners worden per 1 januari 2020 verantwoordelijk voor het beleid ten aanzien van preventie, ondersteuning, bemiddeling en reintegratie (regie WW) (ibid., p. 18).' 
In februari 2015 bracht de Sociaal-Economische Raad, na een moeizaam onderhandelingsproces, het advies Werkloosheid voorkomen, beperken en goed verzekeren uit, waarin de aanbevelingen uit het sociaal akkoord werden uitgewerkt (SER, 2015a). Wie had verwacht dat dit advies een blauwdruk van de 'toekomstige arbeidsmarktinfrastructuur' zou omvatten (zoals de adviesaanvraag luidde), kwam echter bedrogen uit. Terwijl de vakbonden, in het bijzonder de FNV, het advies als een mogelijkheid zagen om de eigen rol in het arbeidsmarktbeleid en bij de 'regie WW' aanzienlijk te versterken, voelden de werkgevers hier weinig voor en zij blokkeerden een grotere rol voor de vakbonden in het publieke bestel van arbeidsvoorziening en WW. Het advies draagt dan ook het stempel van een moeizaam bevochten compromis. Het meest vernieuwende element van het advies is dat er op 'Werkpleinen' in de 35 arbeidsmarktregio's adviescentra worden ingericht die werknemers die met ontslag bedreigd worden of recent zijn ontslagen ondersteunen bij het vinden van een nieuwe baan. Hiermee is gekozen voor een sterke focus op 'van-werk-naar-werk'-beleid. Dat wil zeggen dat het doel vooral is, zoals de titel van het advies luidt, om werkloosheid te voorkomen en het beroep op de WW zo beperkt mogelijk te houden. Anders dan de vakbonden wilden, laat het advies echter open welke partijen die adviescentra gaan invullen. De vakbonden kunnen hierin een rol spelen, maar ook andere partijen. De adviescentra zouden gefinancierd moeten worden uit de premies voor de WW, hetgeen de sociale partners gerechtvaardigd achten vanwege de verwachting dat zij zullen bijdragen aan een minder groot beroep op de WW. Alvorens deze nieuwe structuur in 2020 definitief in werking treedt, stelt de SER voor in de tussenperiode een aantal pilots uit te voeren en deze te evalueren op (kosten)effectiviteit. In een vervolgbrief aan de minister van SZW is het voorstel van de pilots verder uitgewerkt (SER, 2015b). Hierin wordt een onderscheid gemaakt tussen pilots van adviescentra die gericht zijn op individuele dienstverlening en pilots die zijn gericht op betere samenwerking tussen regionale en sectorale arbeidsmarktpartijen.

Het SER-advies beoogt vooral om het gat te vullen tussen het moment dat een werknemer met ontslag bedreigd wordt en het moment dat het UWV de werkloze actief gaat begeleiden. Dit is een belangrijke aanvulling op het bestaande arbeidsmarktbeleid, maar het is vooral complementair aan wat het UWV nu al doet. In die zin kan men moeilijk van een nieuwe arbeidsmarktinfrastructuur spreken. Er is geen sprake van dat de sociale partners hiermee een flink deel terugwinnen van het terrein van sociale zekerheid en arbeidsmarktbeleid dat zij in de jaren go hebben prijsgegeven. De mogelijkheden om weer synergie tot stand te brengen tussen het 
arbeidsvoorwaardenbeleid en het socialezekerheids- en arbeidsmarktbeleid, waarop het sociaal akkoord van 2013 perspectief leek te bieden, zijn hierdoor wel heel beperkt.

Ook in de Participatiewet, die de regelingen voor jonggehandicapten (Wajong), bijstandontvangers (WWB) en de sociale werkvoorziening (WSW) met ingang van 2015 samenvoegt, is een belangrijke rol voor de sociale partners voorzien. Weliswaar ligt de primaire verantwoordelijkheid voor de uitvoering van de Participatiewet bij de gemeenten, maar uitgangspunt is dat zij daarbij in de 35 arbeidsmarktregio's samenwerken met de sociale partners en het UWV. De tewerkstelling van mensen met een beperking, waarvoor de werkgevers hebben toegezegd de komende tien jaar 100.00o plaatsen te zullen creëren (en de overheid nog eens 25.00o), zal in belangrijke mate in praktijk moeten worden gebracht door 35 zogeheten Werkbedrijven, waarin opnieuw de sociale partners een belangrijke rol spelen. Ook hier moet echter nog blijken of de samenwerking tussen lokale overheden en sociale partners een succes zal worden. Het vereist in ieder geval dat zij op één lijn zitten - dit geldt natuurlijk ook voor de vakbonden en de werkgevers -, om te voorkomen dat zich een herhaling voordoet van de mislukte samenwerking tussen lokale overheden en sociale partners in de getripartiseerde besturen van de arbeidsvoorziening in de jaren 9o.

Als de nieuwe verantwoordelijkheidsverdeling inderdaad tot een effectiever sociaaleconomisch beleid leidt, zou dit de proces- en outputlegitimiteit van het poldermodel, net als in de jaren 9o, kunnen vergroten. Hier kan echter spanning ontstaan tussen de activiteiten op de Werkpleinen, die vooral op de insiders zijn gericht (d.w.z. werknemers die nog grotendeels aan het werk zijn) en in de Werkbedrijven, die zich op de outsiders met een grote afstand tot de arbeidsmarkt richten. Aangezien de vakbonden zich het sterkst op de Werkpleinen lijken te richten, kan het beeld ontstaan dat zij hun medeverantwoordelijkheid vooral aanwenden om de belangen van de insiders op de arbeidsmarkt te behartigen. Dit zou hun legitimiteit verder onder druk kunnen zetten. Ook als het beleid niet effectief zou blijken te zijn kan dit, zoals de ervaringen met de verantwoordelijkheid voor de uitvoering van de sociale zekerheid in het verleden hebben uitgewezen, de legitimiteit van het poldermodel ondergraven.

In de vakbeweging leeft de hoop dat een grotere (mede)verantwoordelijkheid voor het arbeidsmarkt- en socialezekerheidsbeleid ook het probleem van de inputlegitimiteit zou kunnen verminderen. Als de vakbonden weer zichtbaarder worden doordat zij in sectoren en regio's bijdragen aan een goed functionerende arbeidsmarkt, zouden zich weer meer werknemers bij de vakbeweging kunnen aansluiten. Daarbij wordt wel verwezen naar 
de landen met een zogenaamd Gent-systeem (België, Zweden, Noorwegen), waarin de vakbonden verantwoordelijk zijn voor de uitvoering van de werkloosheidsverzekeringen. In die landen is meer dan de helft van de werknemers vakbondslid. Of een grotere verantwoordelijkheid voor het arbeidsmarkt- en socialezekerheidsbeleid een vergelijkbaar effect zal hebben, staat echter nog te bezien. Waarschijnlijk zullen de vakbonden slechts op een deel van de Werkpleinen hun eigen herkenbare adviescentra kunnen openen. In de andere regio's zullen zij dus veel minder zichtbaar zijn. Bovendien zullen zij geen rol spelen bij de claimbeoordeling, of de uitbetaling van de WW voor hun rekening gaan nemen, hetgeen de grootste zichtbaarheid zou opleveren. En ten slotte is natuurlijk ook de effectiviteit van het beleid van belang. Een werkzoekende die dankzij ondersteuning door de vakbond - of een organisatie waarin de vakbond participeert werk vindt, zal om die reden wellicht besluiten vakbondslid te worden. Maar als die begeleiding geen resultaat oplevert, is dit aanzienlijk minder waarschijnlijk.

Het lijkt onwaarschijnlijk dat een grotere verantwoordelijkheid voor het arbeidsmarkt- en socialezekerheidsbeleid alleen, voldoende zal zijn om de dalende trend in de organisatiegraad van de vakbeweging om te buigen naar een stijgende trend, en het ledenbestand van de vakbeweging weer meer een afspiegeling te maken van de gehele werkende bevolking. Om het representativiteitsprobleem te verkleinen zijn daarom aanvullende maatregelen nodig. Hiervoor zijn globaal twee trajecten denkbaar. Het eerste traject houdt in dat langs andere wegen het ledental wordt vergroot. Hiervoor worden in de vakbeweging al jarenlang ideeën geopperd en deels ook uitgevoerd, zoals specifieke ledenvoordelen, organizing en acties gericht op jongeren. Tot op heden hebben deze de neergang in het ledental echter niet tot staan weten te brengen, alhoewel in 2014 voor het eerst in vele jaren het aantal jongere leden iets is toegenomen. Het lijkt riskant om hierop veel vertrouwen te stellen voor de toekomstige ontwikkeling.

Het tweede traject houdt in dat men de representativiteit en legitimiteit van de vakbeweging niet (alleen) probeert te vergroten door meer leden te werven, maar door niet-leden meer bij de vakbonden te betrekken. Door bijvoorbeeld de inzet voor en de uitkomst van de cao-onderhandelingen aan alle werknemers in een bedrijfstak of onderneming voor te leggen in plaats van alleen aan de leden, kunnen vakbonden de legitimiteit van hun rol als vertegenwoordiger van alle werkenden vergroten. Het gebruikelijke en begrijpelijke tegenargument vanuit de vakbeweging is dat er dan nog minder reden is om lid te worden van een vakbeweging. Dit versterkt immers het free rider-probleem. Om dit probleem te verzachten zouden vakbonden voor de 
financiering van hun activiteiten minder afhankelijk moeten worden van de contributie van hun leden. Een denkbare optie is dat er een 'cao-heffing' over het loon van alle werknemers in een onderneming of bedrijfstak wordt ingevoerd, zodat ook de niet-vakbondsleden meebetalen aan de kosten van het onderhandelen over en het afsluiten van cao's (zie hierover ook De Beer, 2014).

\section{Conclusie}

Het oordeel over de stand van het poldermodel anno 2016 is onvermijdelijk gemengd. Aan de ene kant is het poldermodel een toonbeeld van stabiliteit en continuïteit en vormt het een belangrijke basis onder het sociaaleconomisch beleid van achtereenvolgende kabinetten - ongeacht de politieke samenstelling. Bovendien vormt de cao nog altijd de kern van ons stelsel van geordende arbeidsverhoudingen en bepaalt deze nog steeds voor een grote meerderheid van de werkenden de arbeidsvoorwaarden. Aan de andere kant staat het poldermodel onder druk, doordat de inputlegitimiteit van de polderpartners - en in het bijzonder van de vakbeweging - steeds vaker betwist wordt. Bovendien is de proceslegitimiteit verminderd doordat de koppeling tussen de uitvoering van het sociaaleconomisch beleid (in het bijzonder sociale zekerheid en arbeidsmarktbeleid) en het arbeidsvoorwaardenbeleid, die de sociale partners niet alleen medeverantwoordelijk maakte voor de vormgeving maar ook voor de uitvoering van het sociaaleconomisch beleid, is verbroken. Ten slotte kan Nederland in het tweede decennium van de eenentwintigste eeuw ook niet meer bogen op sociaaleconomische prestaties die superieur zijn aan die van de buurlanden, waardoor ook de outputlegitimiteit is afgenomen.

Of een grotere rol van de sociale partners in het arbeidsmarktbeleid, waarover de SER begin 2015 advies heeft uitgebracht, veel zal bijdragen aan versterking van de proces- en de outputlegitimiteit van de sociale partners, en in het bijzonder de vakbeweging, staat nog te bezien. Om ook de inputlegitimiteit van de vakbeweging te vergroten zal de dalende trend in het ledenbestand moeten worden gekeerd. Het is de vraag of dit binnen de bestaande structuren een realistische optie is. Waarschijnlijk is daarvoor een fundamentele verandering in het vertegenwoordigings- en financieringsmodel van de vakbeweging nodig, waarbij alle werknemers invloed krijgen op het functioneren van de vakbeweging maar er ook financieel aan bijdragen. Zonder ingrijpende veranderingen is het de vraag of het poldermodel ook de komende decennia een stevige basis voor het Nederlandse sociaaleconomische model zal kunnen blijven vormen. 



\title{
5 De keerzijde van het polderwonder
}

\author{
Ewald Engelen
}

Mirakel: bovennatuurlijk feit, wonder.

Dikke Van Dale

If something looks too good to be true, it probably is.

Amerikaans gezegde

Wat zouden we er niet voor hebben om nu met net zoveel zelfvertrouwen het woord 'mirakel' te kunnen meegeven aan de titel van een boek over de Nederlandse politieke economie. Het is inmiddels bijna twintig jaar geleden dat het gelijknamige boek van Jelle Visser en Anton Hemerijck verscheen (Visser en Hemerijck, 1997). In dat jaar reisde de hele wereld naar Nederland om uitgelegd te krijgen hoe dat kleine landje aan de Noordzee er toch in was geslaagd van de zieke man van Europa een van de meest dynamische economieën te worden, bewonderd om zijn lage werkloosheid, bejubeld om zijn multiculturalisme en geprezen om zijn pragmatische, postideologische bestuurscultuur.

Mirakel suggereert iets onverwachts, iets onmogelijks, iets uit het ongerijmde, en vereiste daarom retorisch een gezaghebbende schets van de impasse waarin de Nederlandse economie voorafgaand aan het wonder was beland. Visser en Hemerijck beginnen hun boek dan ook met de hyperbolische uitspraak van de Zweedse socioloog Göran Therborn uit 1986 dat Nederland wat hem betreft het meest 'spectaculaire' voorbeeld was van een 'werkgelegenheidsramp' (Therborn, 1986). De aardgasvondst in Slochteren in 1959 had burgers en elite lui, inhalig en zelfgenoegzaam gemaakt. De gratis gasdollars werden omgezet in genereuze uitkeringen en resulteerden in 1982 in een diepe economische crisis met een van de hoogste werkloosheidcijfers van Europa, een gierend begrotingstekort en een snel oplopende staatsschuld. Het zou in de Engelstalige literatuur de Dutch disease gaan heten.

Hoe anders was het beeld tien jaar later. Zoals Visser en Hemerijck schrijven: 'Over the past years, the Dutch political economy has become the wonder and sometimes envy of foreign observers' (1997, p. 7). Wie herinnert zich niet de adoratie van Blair, Schröder, Delors en Clinton voor het poldermodel? En wie is vergeten dat de Stichting van de Arbeid (StvdA) in 
1997 de prestigieuze Bertelsmann-prijs kreeg voor haar bijdrage aan het Nederlandse succes? Inderdaad waren de prestaties opmerkelijk, om niet te zeggen: miraculeus. De werkloosheid was zo ongeveer gehalveerd, de arbeidskosten waren zo ongeveer de laagste van Noord-Europa, de participatiegraad was omhoog gesprongen, de banengroei was van Amerikaans kaliber, het begrotingstekort was geslonken tot 2 procent, de staatsschuld bedroeg nog maar 68 procent van het bruto binnenlands product (bbp) en de collectieve uitgaven waren teruggebracht van het Zweedse niveau van 65 naar het Britse niveau van 45 procent van het bbp. En dat zonder noemenswaardige onlusten, demonstraties en stakingen (zie ook WRR, 2007).

Hoe had Nederland hem dat geflikt? Zoals de ondertitel suggereert - 'Beleidsleren in de Verzorgingsstaat' - was dat volgens de auteurs in belangrijke mate te danken aan lerende beleidsmakers. Zij laten er geen twijfel over bestaan dat het zaad van het latere wonder in 1982 is gezaaid met dat veelgeroemde Akkoord van Wassenaar, toen FNV-voorman Wim Kok, gezeten aan de keukentafel in de Wassenaarse woning van VNO-voorzitter Chris van Veen, bereid bleek loonmatiging te ruilen voor arbeidsduurverkorting. Die verkorting is er weliswaar maar mondjesmaat gekomen (zie De Beer 2012), maar de loonmatiging wel, en dat stimuleerde de winsten, drukte de werkloosheid en creëerde de groei die onder Paars herziening van de sociale zekerheid en nog veel meer mogelijk maakte.

Het was een meesterzet, aldus Visser en Hemerijck. De achterban was bereid minder sociale zekerheden te accepteren omdat er stomweg meer banen tegenover stonden en er daardoor eindelijk weer inkomenszekerheid was. Maar actief arbeidsmarktbeleid - het derde verzorgingsstatelijke domein dat de auteurs onder de loep nemen - is bijvoorbeeld nooit echt van de grond gekomen. Het tekent het belang van Fortuna, zoals de auteurs in de laatste zin van het boek, onder verwijzing naar de beroemde Machiavelliaanse tweeling Virtu en Fortuna, constateren: 'policy learning cannot do without Fortuna' (1997, p. 185).

Inmiddels zijn we bijna twintig jaar verder en is meer en meer de keerzijde van het Nederlandse mirakel zichtbaar geworden, zeker sinds het uitbreken van de crisis in 2008. Zoals bewindslieden niet moe worden te benadrukken, doet Nederland het uitstekend op de internationale lijstjes die mondiale competitiviteit, geluk en levenskwaliteit meten. Verder is er een aantal indicatoren waarop Nederland, ook tijdens de crisis, internationaal redelijk tot goed scoort. Zo is de werkloosheid nog altijd aan de lage kant; is de overheidsschuld relatief laag; kent Nederland een groot overschot op de betalingsbalans; is de internationale vermogenspositie van Nederland 
uitmuntend; kent Nederland een groot spaaroverschot; heeft Nederland veel internationaal toonaangevende ondernemingen binnen de grenzen; is de Nederlandse beroepsbevolking hoog opgeleid; zijn Nederlandse universiteiten goed tot zeer goed als je kijkt naar aantallen internationale publicaties; is Nederland nog altijd een van de rijkste landen ter wereld; en spreekt uit de buitengewoon lage rentes die de Nederlandse overheid op de internationale kapitaalmarkten betaalt een groot vertrouwen in de kwaliteit van de Nederlandse instituties.

Tegenover dit fraaie plaatje staan echter minder mooie cijfers: lage en tot 2015 dalende consumentenbestedingen; bij inflatie en productiviteit achterblijvende lonen; scherp gestegen werkloosheid (pakweg 400.000 werklozen erbij sinds 2008); een recordaantal bedrijfsfaillissementen; stijgende voorzieningen van banken op slechte leningen; kantorenleegstand van landelijk 15 procent, met uitschieters naar 30 procent in Amstelveen, Alphen aan den Rijn en Heerlen; stijgende afwaarderingen op vastgoed bij ziekenhuizen, scholengemeenschappen, universiteiten, zorginstellingen en lokale overheden; achterblijvende investeringen in onderwijs; dure en matige kinderopvang, die bovendien wordt uitgemolken door AngloAmerikaanse private equity-huizen (zie Estro); toenemende afschrijvingen op grondposities door een groeiend aantal gemeenten; huizenprijzen die sinds 2008 reëel met pakweg 25 procent zijn gedaald; een stijgend aantal huishoudens dat aanhikt tegen negatief vastgoedvermogen; en, vooral, torenhoge en stijgende private schulden, die met een omvang van meer dan 315 procent van het gemiddeld besteedbaar huishoudinkomen tot de hoogste ter wereld behoren. En ook al tekent zich sinds eind 2014 geleidelijk herstel af, de Nederlandse economie is op het moment van schrijven ( 3 april 2016) pas onlangs (4de kwartaal 2015) een fractie groter dan in de herfst van 2008 en heeft er daarmee langer over gedaan om de crisis achter zich te laten dan tijdens de Grote Depressie van de jaren dertig (Keesing, 1978).

In dit hoofdstuk probeer ik de vraag te beantwoorden wat deze twee kanten van het mirakel met elkaar te maken hebben. Het korte antwoord luidt: door het gefragmenteerde karakter van de elite is in Nederland na de winstgevendheidscrisis van de jaren zeventig een hybride groeimodel ontstaan dat de binnenlandse gevolgen van exportgedreven groei ('loonmatiging') heeft proberen te compenseren met schuldgedreven groei ('vastgoed'). Toen in 2008 de interbancaire kredietverlening stokte en Nederlandse banken in grote problemen kwamen, werden de onbedoelde neveneffecten van dit hybride model voor eenieder zichtbaar. Het onvermogen van politici en beleidsmakers om de grote problemen waar de Nederlandse economie sinds het uitbreken van de crisis mee worstelde in hun samenhang te zien, 
roept grote vragen op over hun leervermogen. Met terugwerkende kracht, zo betoog ik in de conclusie van dit hoofdstuk, is de notie van beleidsleren die Visser en Hemerijck in 1997 introduceerden om het paarse mirakel te verklaren misschien minder op zijn plaats dan 'institutioneel doormodderen', waarmee ik op een veel grotere invloed voor pad-afhankelijkheid en institutioneel determinisme op beleidsbeslissingen doel dan de meer voluntaristische associaties die 'leren' oproept.

De opzet van dit hoofdstuk is als volgt. De eerstvolgende paragraaf laat zien waarom de Nederlandse politieke economie zo lastig te classificeren is en presenteert data die meer precies laten zien op welke manier de Nederlandse politieke economie afwijkt van haar Europese buren. De paragraaf daarna toont wat daarvan de gevolgen zijn geweest. De eropvolgende paragraaf probeert die gevolgen te verklaren en betoogt dat een deel van de verklaring is gelegen in een diepgeworteld ideologisch mercantilisme dat al decennia de Nederlandse beleidselite gijzelt. De slotparagraaf, ik memoreerde het al, trekt deze lijn door en betoogt dat mirakel en keerzijde het gevolg zijn van een elite die steeds meer is gefragmenteerd en daardoor niet langer het politiek-strategisch vernuft kan opbrengen om te breken met het verdienmodel dat de Nederlandse economie zo kwetsbaar heeft gemaakt.

\section{Het hybride mirakel}

Al bijna twintig jaar worstelen sociale wetenschappers met het adequaat classificeren van de Nederlandse politieke economie. Neem het veelgeprezen Varieties of Capitalism uit 2001 van de Amerikaanse politicoloog Peter Hall en de Britse econoom David Soskice. Daarin constateerden zij dat ontwikkelde economieën grofweg in twee ideaaltypen uiteenvielen. De allocatie van kapitaal, arbeid, goederen en diensten gebeurde ofwel vooral via het prijsmechanisme ofwel vooral via politieke afstemming en onderhandeling. De eerste noemden zij Liberale markteconomieën, de tweede Gecoördineerde markteconomieën; de VS was het exemplarische voorbeeld van de eerste, Duitsland van de tweede (Hall en Soskice, 2001).

Dat wilde niet zeggen dat in de eerste geen onderlinge afstemming plaatsvond en dat er in de tweede geen plaats voor marktruil was. Hall en Soskice gebruikten de tweedeling slechts om in het oog springende verschillen in de organisatie van het economisch leven in hoogontwikkelde economieën te doen oplichten. Volgens de auteurs hadden de meeste Noordwest-Europese economieën meer weg van het Duitse prototype dan van het Amerikaanse, terwijl voor het Verenigd Koninkrijk (VK) en zijn voormalige koloniën 
(Canada, Nieuw-Zeeland, Australië) het omgekeerde gold. Hall en Soskice gebruikten daar een breed scala aan meer of minder gestandaardiseerde empirische indicatoren voor, zoals de zogenaamde Hicks-Kenworthy-index die ook wel corporatisme-index wordt genoemd (Hicks en Kenworthy, 1998; zie ook Kenworthy, 2000).

Als we naar de score van Nederland op deze index kijken en deze vergelijken met Duitsland en de VS, hebben Hall en Soskice gelijk. Deze index meet de mate van corporatisme in verschillende landen aan de hand van de scores op indicatoren als de mate van samenwerking tussen bedrijven; het bereik van collectieve arbeidsovereenkomsten; de mate van samenwerking tussen overheid en belangenvertegenwoordigers (vakbonden en werknemersvertegenwoordigers); de aan- of afwezigheid van formele tripartiete onderhandelingsplatforms (zoals de Sociaal-Economische Raad - SER); de aard van de relaties tussen bedrijven en investeerders en tussen toeleveranciers en eindafnemers; de gemiddelde duur van arbeidscontracten; en de kwaliteit van de arbeidsverhoudingen op de werkvloer. Op basis daarvan kent de index landen een cijfer toe tussen de nul en één, waarbij nul staat voor geen corporatisme en één voor puur corporatisme.

Zoals tabel 5.1 laat zien, scoorde Nederland tussen 1960 en 1989 gemiddeld o.66, tegen 0.81 in Duitsland en 0.08 in de VS over diezelfde periode - een duidelijke ondersteuning voor de stelling van Hall en Soskice, en al evenzeer een bevestiging dat Nederland volgens deze index (en in die periode) in het corporatisme-kamp hoort. Zestien jaar later, na de neoliberale revolutie van Paars I en II, zijn alle landen gezakt in termen van hun corporatisme-score, maar het patroon: hoge score voor Gecoördineerde markteconomieën, lage score voor Liberale markteconomieën, is ongewijzigd.

Tabel 5.1 Nederland op de corporatisme-index

\begin{tabular}{lcc}
\hline & $\mathbf{1 9 6 0 - 1 9 8 9}$ & $\mathbf{2 0 0 5}$ \\
\hline Duitsland & 0.81 & 0.795 \\
Nederland & 0.66 & 0.578 \\
Verenigd Koninkrijk & 0.15 & 0.096 \\
Verenigde Staten & 0.08 & 0.023 \\
\hline
\end{tabular}

Bron: Hicks en Kenworthy (1998, p. 1649); Gourevitch en Shinn (2005, p. 154)

Volgens Hall en Soskice hoort Nederland dan ook overduidelijk in het kamp van de Gecoördineerde markteconomieën. Met zijn hoge mate van ontslagbescherming, zijn structuurregime dat vakbonden het recht gaf commissarissen te benoemen, zijn wettelijk voorgeschreven ondernemingsraden, zijn 
beroepsonderwijs dat leerlingen naar nauw gedefinieerde arbeidsmarktsegmenten loodst en zijn internationaal vrij beperkte bescherming van kleine aandeelhouders, voldeed Nederland op alle cruciale indicatoren aan het Duitse archetype. In Nederland vond sectorale afstemming volgens Hall en Soskice eerder plaats via politieke kanalen dan via het prijsmechanisme.

Deze classificatie mist echter volledig de grote verschillen die er bestaan in de wijze waarop en de mate waarin huishoudens en ondernemingen zijn aangewezen op externe kapitaalverstrekkers en kredietverleners voor het realiseren van hun plannen en strategieën. Oftewel, datgene wat in de sociaal-wetenschappelijke literatuur de financialisering van economie en samenleving wordt genoemd (zie Engelen en Konings, 2010; Van der Zwan, 2014 voor overzichten). En dat heeft alles te maken met de disciplinaire herkomst van het merendeel van de onderzoekers, werkzaam in de Varieties of Capitalism-school. Wie intellectueel is opgegroeid als arbeidssocioloog of arbeidseconoom heeft nu eenmaal voornamelijk oog voor de institutionele inrichting van arbeidsmarkten en verzorgingstaten (zie Engelen en Konings, 2010). Kijk je echter naar financiële indicatoren als de omvang van kapitaalmarkten, de openheid van nationale economieën voor buitenlands kapitaal of de mate waarin banken zich hebben getransformeerd in herverpakkers van hypotheken, dan zie je iets heel anders (zie ook SFL, 2014; Bezemer en Muysken, 2015; Hardie et al., 2013).

Eerst de omvang van kapitaalmarkten. Geheel conform de verwachtingen van Hall en Soskice waren in 2008 de Amerikaanse markten voor aandelen en obligaties uitgedrukt als percentage van het bbp het grootste (36o procent) en in Duitsland het kleinste (230 procent). Het VK zit daar met 280 procent mooi tussenin. Maar wat botst met Hall en Soskice is Nederland. Met $33^{\circ}$ procent van het bbp passeert het het VK, steekt het de VS naar de kroon en laat het alle Noordwest-Europese economieën ver achter zich.

Of neem het pensioenstelsel. Op het Europese continent domineert het zogenoemde omslagstelsel. De huidige gepensioneerden ontvangen een oudedagsvoorziening die wordt betaald uit de premies die de huidige werkenden maandelijks afdragen. Met de Zwitsers, de Britten, de Amerikanen en, in mindere mate, de Scandinavische landen hebben wij eind negentiende eeuw gekozen voor een kapitaaldekkingsstelsel. Iedereen spaart voor zijn eigen pensioen door maandelijks in een grote pot in te leggen, die vervolgens wordt belegd door financiële producten te kopen: aandelen, obligaties, opties en andere derivaten. Hoe hoger het rendement op deze beleggingen, hoe lager de premies. Zo heeft Nederland meer dan $€$ 1000 miljard aan pensioenvermogen gespaard, per hoofd van de bevolking het hoogste bedrag ter wereld. Maar met de afhankelijkheid die daar voor 
huishoudens en werkgevers van financiële markten uit voortvloeit, lijkt Nederland, in tegenstelling tot wat Hall en Soskice beweren, veel meer op de VS dan op Duitsland of de rest van Europa (OESO, 2013).

Of neem de omvang van de bancaire sector. Op basis van Hall en Soskice is de verwachting dat Liberale markteconomieën een kleine bancaire sector paren aan diepe kapitaalmarkten en dat voor Gecoördineerde markteconomieën precies het omgekeerde geldt: een grote bancaire sector met kleine kapitaalmarkten. Dat komt doordat in Liberale markteconomieën de allocatie van kapitaal vooral via markten loopt en niet via banken (zie Gerschenkron, 1962 Zysman, 1983; Hardie et al. 2013). Zo op het eerste gezicht klopt het. De bancaire sector is in de VS met één keer bbp veel kleiner dan in Duitsland, waar de bancaire sector 250 procent van het bbp bedraagt. Tel je daar de kapitaalmarkten bij op, dan kom je zowel in de VS als in Duitsland op een financiële sector die pakweg vijf keer het bbp bedraagt.

Zo niet Nederland. Eerder bleek al dat de Nederlandse kapitaalmarkten ongeveer even groot waren als de Amerikaanse. De Nederlandse bancaire sector is echter twee keer zo groot als de Duitse, vijf maal bbp. Dat maakt een financieel waterhoofd van 830 procent van het bbp, relatief veel groter dan zowel de VS als Duitsland, zoals figuur 1 laat zien. Overigens is de bancaire sector in het VK in 2008 met zes keer bbp nog net iets groter, waardoor het VK bij elkaar opgeteld op 880 procent van het bbp komt, net boven Nederland.

\section{Figuur 5.1 Omvang kapitaalmarkten en bankbalansen (in \% van het bbp)}

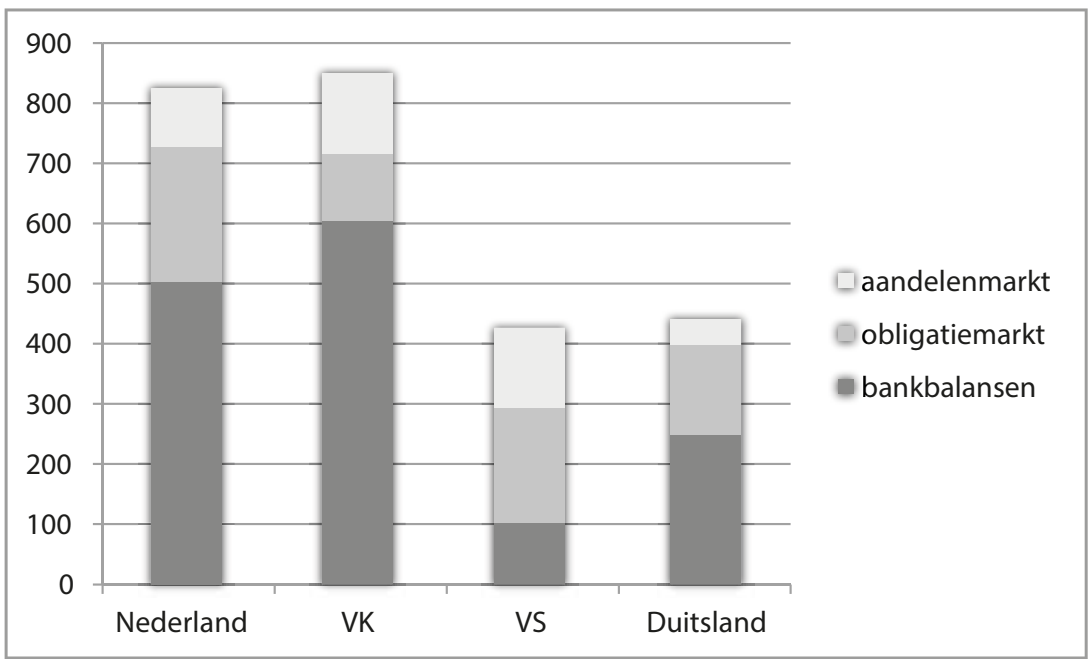

Bron: Engelen et al., 2010 
Nog geprononceerder wordt het gefinancialiseerde karakter van de Nederlandse economie door er de mate van financiële openheid aan toe te voegen. De meest gebruikte maatstaf hiervoor is de omvang van in- en uitgaande directe investeringen. Dit omvat zowel investeringen in nieuwe bedrijfsvestigingen, overnames van reeds bestaande bedrijven, als portfolio-investeringen (het kopen van bedrijfsaandelen of bedrijfsobligaties). Kapitaalstromen die vooral fiscaal gedreven zijn (belasting- en toezichtontwijking), vallen erbuiten. Het model van Hall en Soskice doet verwachten dat Gecoördineerde markteconomieën lagere niveaus van buitenlandse investeringen kennen dan Liberale. Dat komt doordat er door minder dynamiek minder marktopeningen zijn en doordat de huidige kapitaalverschaffers vanwege hun langetermijnoriëntatie minder snel geneigd zijn hun eigendomstitels aan buitenstaanders te verkopen.

Ook dit lijkt zo op het eerste gezicht te kloppen. Als we Duitsland met het VK vergelijken - economieën met een vergelijkbare omvang -, dan zien we dat de inkomende buitenlandse investeringen in Duitsland in 2005 minder dan de helft zo groot waren als in het VK, 14 om 32 procent van het bbp. Terwijl de uitgaande buitenlandse investeringen van het VK in datzelfde jaar ook ruim twee keer zo groot waren, 62 om 38 procent van het bbp. Vanwege de veel grotere omvang van de Amerikaanse economie en haar veel geringere buitenlandse afhankelijkheid gaat een vergelijking met de middelgrote Europese economieën mank. Weer is Nederland het buitenbeentje. Met inkomende buitenlandse investeringen van 74 procent en met uitgaande buitenlandse investeringen van iets meer dan eenmaal het bbp is Nederland een van de meest open economieën ter wereld.

Dit wordt bevestigd door het hoge percentage buitenlandse eigenaren van de aan Euronext Amsterdam genoteerde aandelen. Omdat Euronext niet langer gegevens publiceert over de afzonderlijke handelsplatforms, moeten we het doen met data uit 2005. Toen was bijna 70 procent van alle aandelen in handen van beleggers met buitenlandse identificatienummers, na Hongarije het hoogste van alle rapporterende beurzen (FESE, 2007. Hetzelfde geldt voor het Nederlandse pensioenvermogen. Is in de VS slechts 17 procent in het buitenland belegd en in het VK maar 35 procent, in Nederland is dat een ongekende 77 procent (zie Engelen et al., 2009; Engelen en Konings, 2010).

In combinatie met de pakweg $€ 11.000$ miljard die op jaarbasis (in- en uitstromend) door de 24 duizend brievenbusmaatschappijen vloeit die Nederland naar schatting herbergt (SOMO, 2013; DNB, 2012; SEO, 2013; DNB 2015), doemt het beeld op van een financieel waterhoofd van ongekende proporties dat cruciale doorsluisfuncties vervult in het mondiale 
gefinancialiseerde kapitalisme. Afgaand op rapportage van na de crisis van de Financial Stability Board (FSB) behoort pakweg een kwart ervan, $€ 3000$ miljard, tot het schaduwbancaire stelsel. De rest is industrieel kapitaal, dat om fiscale redenen Nederland aandoet (FSB, 2012). Tellen we deze schaduwbancaire markt op bij de eerdere som van kapitaalmarkten en Nederlandse bankbalansen van 830 procent van het bbp, dan huisvest Nederland in totaal pakweg 1230 procent van het bbp aan geparkeerd financieel kapitaal. Dat is in absolute termen bijna evenveel als er in heel Duitsland beschikbaar is. Maar dat is wel een vier keer zo groot land met een vier keer zo grote economie.

Het financialiseringsplaatje wordt compleet door er indicatoren van wat vóór de crisis financiële innovatie heette aan toe te voegen. Sinds de jaren 80 van de vorige eeuw heeft zich in de bancaire sector een stille revolutie voltrokken. Niet alleen zijn de balansen sterk gegroeid, is het eigen vermogen gelijk gebleven, is de hefboom ('leverage ratio') daardoor enorm verlengd en zijn de winst-per-aandeel en de daaraan gekoppelde bonussen sterk gestegen, ook heeft zich een ongekende transformatie voorgedaan in het verdienmodel van banken.

Werd het klassieke bankieren de publieke beeldvorming geregeerd door de zogenaamde 3-6-3-regel (voor 3 procent inlenen, voor 6 procent uitlenen en om drie uur 's middags op de golfbaan), sinds 1980 ontlenen banken een groeiend deel van hun financiering aan het zo snel mogelijk wegzetten van zo veel mogelijk verpakte producten, vooral hypotheken, op de interbancaire bank. De kopers zijn andere banken, institutionele beleggers, geldmarktfondsen, hedge fondsen. Een bank is niet langer een tussenpersoon die bemiddelt tussen huishoudens met overtollig spaargeld (depositohouders) en bedrijven met een kredietbehoefte (midden- en kleinbedrijf - MKB) ondertussen het renteverschil opstrijkend, maar is meer en meer een complexe financiële productielijn geworden die doorsnee schuldcontracten transformeert in hoogwaardige obligaties die als onderpand dienen voor goedkope financiering op de interbancaire markt, waarna het spel weer opnieuw begint - onderwijl bij iedere stap commissies innend (zie Ertürk en Solari, 2007; Engelen et al., 2011; Hardie et al., 2013; Bezemer en Muysken, 2015).

De mate waarin banken zich van tussenpersonen hebben getransformeerd tot financiële poductielijnen verschilt echter van land tot land. Er zijn verschillende maatstaven om deze transformatie te meten, maar de meest voor de hand liggende zijn (i) de verdeling in bancaire inkomsten in verschillende landen tussen rente-inkomsten (het klassieke bankieren) en commissie-inkomsten (het gefinancialiseerde bankieren), en (ii) het 
Figuur 5.2 Commissie-inkomsten in \% totale bancaire inkomsten

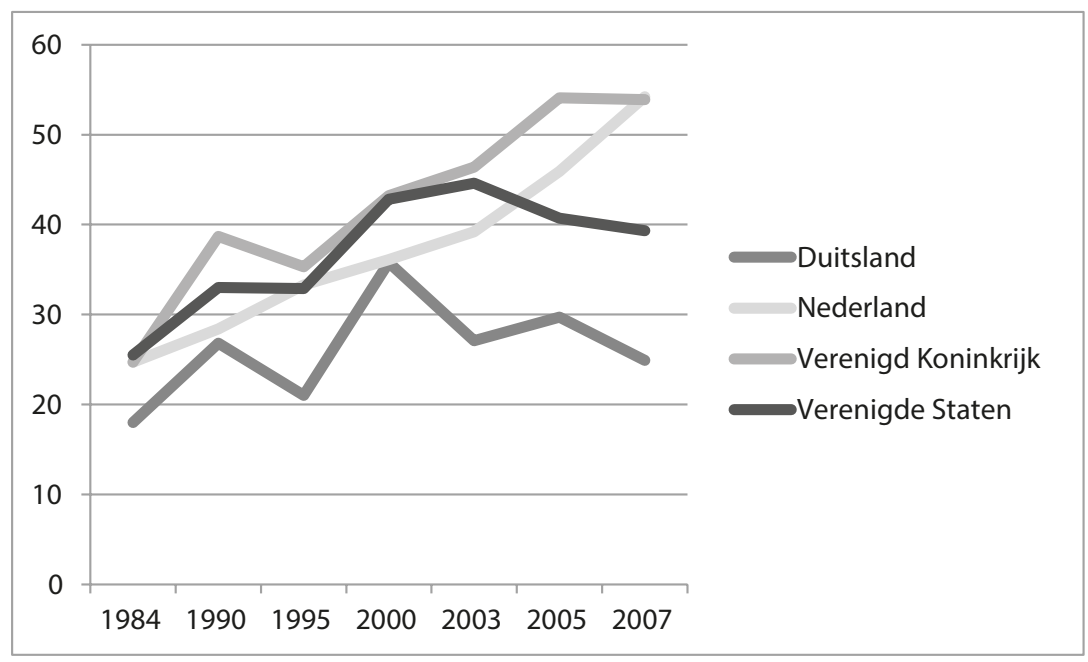

Bron: OESO Bank profitability database

marktaandeel van verschillende landen in de markt voor verpakte leningen. Het verband tussen de twee is dat het verpakken van hypotheken en andere leningen veel commissie-inkomsten oplevert. Dus hoe meer er verpakt (gesecuritiseerd) wordt, hoe groter het aandeel van commissies in de totale inkomsten zal zijn.

Zoals figuur 5.2 laat zien, staaft de inkomstenverdeling bij Amerikaanse en Duitse banken de analyse van Hall en Soskice, namelijk hoge(re) commissie-inkomsten bij Amerikaanse banken versus hogere rente-inkomsten bij Duitse banken: commissie-inkomsten bij banken in Liberale markteconomieën zijn structureel 40 procent hoger dan in Gecoördineerde markteconomieën. Dat geldt weer niet voor Nederland. Het verdienmodel van Nederlandse banken lijkt meer op Amerikaanse dan op Duitse banken. Was het aandeel van de commissie-inkomsten in de totale inkomsten van Nederlandse banken in 1985 exact even hoog als bij Amerikaanse, in 2007 was het zelfs hoger dan in de VS en even hoog als in het VK.

Deze verregaande financialisering heeft alles te maken met de hypothecaire verpakkingsindustrie die Nederlandse banken sinds midden jaren 90 van de vorige eeuw hebben opgetuigd. Data van het Europese Securitisatie Forum (ESF) leren dat in de jaren vóór de crisis op het Europese continent nauwelijks hypotheken werden verpakt. In 2006 bedroeg het totaal aan uitstaande securitisaties in Frankrijk en Duitsland minder dan 5 procent 
Figuur 5.3 Uitstaande securitisaties in \% van het bbp in 2006

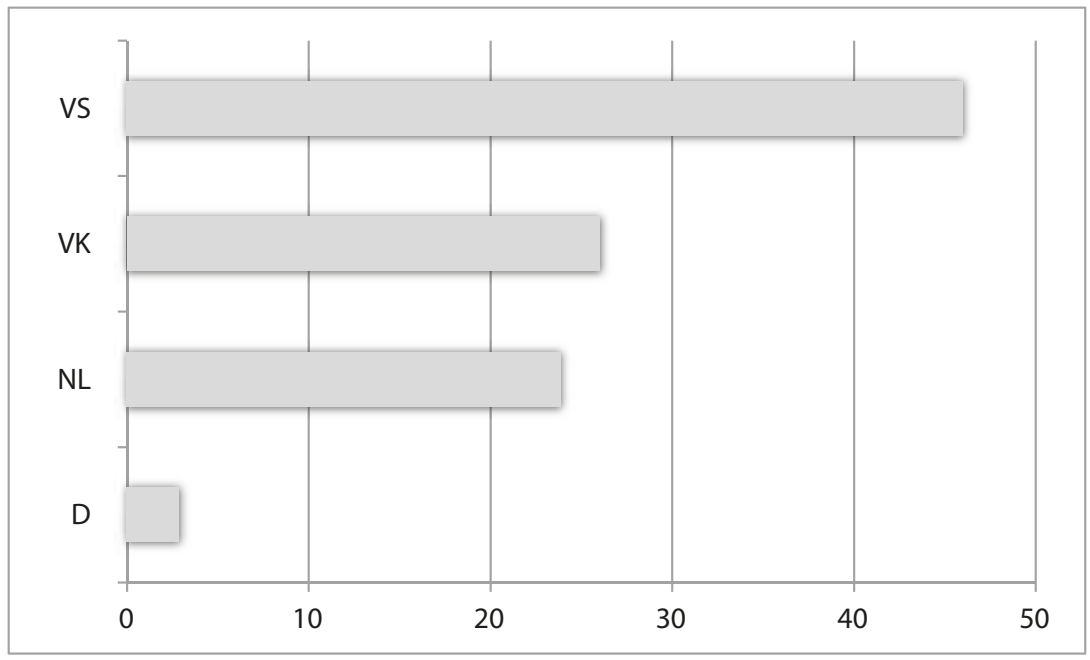

Bron: European Securitisation Forum

van hun respectievelijke bbp's. In Liberale markteconomieën daarentegen was het uitgegroeid tot een van de voornaamste bancaire financieringskanalen. In de VS en in het VK bedroegen de uitstaande securitisaties in 2006 45 en 26 procent van de respectievelijke bbp's, zoals figuur $5 \cdot 3$ demonstreert.

Het wordt eentonig - maar weer is Nederland het Europees buitenbeentje. Meegenomen door Nederlandse bankiers, die het trucje in New York hadden geleerd, dateert de eerste Nederlandse securitisatie uit 1997, toen de zakenbank van Fortis voor VSB Bank voor $€ 227$ miljoen aan hypothecaire leningen doorverkocht (zie Aalbers et al., 2011; Engelen, 2015). Sindsdien zijn er tot en met 2008207 gevolgd, het merendeel hypotheken, maar ook commerciële vastgoedleningen, leasecontracten, autoleningen, synthetische securitisatie en zelfs zogenoemde tweede-orde-securitisaties: het herverpakken van de risicovolle restanten van gewone securitisaties, de zogenaamde 'Collateralized Debt Obligations' (CDO's). Iets wat veel restafval en dus een productieve verpakkingslijn vooronderstelt, en om die reden alleen in de VS en in het VK op grote schaal werd gedaan. En dus ook in Nederland.

In totaal is in Nederland vóór de crisis voor bijna $€ 60$ miljard aan restafval herverpakt. En dat kan alleen omdat de totale waarde van de Nederlandse securitisaties tot aan 2008 cumulatief bijna $€ 350$ miljard bedroeg, meer dan 50 procent van het bbp. Dat betekent dat zonder dat de 
debiteur ervan verwittigd werd ('stille cessie'), pakweg een kwart van de hypotheekcontracten door de Nederlandse grootbanken is doorverkocht aan buitenlandse beleggers: het andere kwart, vooral sinds 2008 geproduceerd, werd op de eigen balans gehouden om als onderpand te dienen voor financiering door de ECB. Dat was verhoudingsgewijs meer dan waar ook ter wereld.

\section{Het schizofrene mirakel}

Om te begrijpen waar deze wonderlijke mix van corporatisme en financialisering vandaan komt, moeten we terug naar 1959, toen in de Groningse gemeente Slochteren een ongekend grote voorraad aardgas werd gevonden. De gratis gasdollars die dat opleverde, werden onder sociaal- en christendemocratische voormannen aangewend voor genereuze uitkeringen, fraaie publieke diensten, blinkende infrastructuur en hoge lonen. Zo zijn substantiële delen van wegennet en spoorlijnen, de massa-universiteit, de sociale huisvesting, het welzijnswerk en het merendeel van de volksverzekeringen betaald uit gasinkomsten - met een snel groeiend ambtenarenapparaat, groeiende overheidsverplichtingen en afnemende ruimte voor nieuw beleid tot gevolg (CPB, 2006; zie Corden en Neary, 1982, voor de klassieke analyse).

Onder invloed van de gasinkomsten stegen de collectieve uitgaven van pakweg 40 procent van het bbp tot meer dan $5^{\circ}$ procent. En het merendeel daarvan bestond uit 'distributief beleid', zoals het Centraal Planbureau het noemde, oftewel uitkeringen aan burgers die om wat voor reden dan ook niet in het eigen levensonderhoud konden voorzien (CPB, 2006). Deze uitkeringen waren geëxplodeerd van 6 procent van het bbp in 1950 naar 25 procent in 1980. In een toch al zwakke internationale conjunctuur dreigde de dure Nederlandse verzorgingsstaat door hoge sociale lasten en sterk stijgende loonkosten langzaam de lucht uit het exporterende grootbedrijf te persen.

In 1982 leidde dat - na twee oliecrises (1973 en 1979) - tot een diepe economische recessie met een van de hoogste werkloosheidspercentages van West-Europa (9,7 procent), een gierend begrotingstekort (6 procent in 1981) en een snel oplopende staatsschuld, die tegen het einde van de jaren 80 het peil van 80 procent van het bbp had bereikt (CPB 2006). Het stijgende binnenlandse loonpeil als gevolg van gratis gasinkomsten had het verdienvermogen van het exporterende grootbedrijf zodanig aangetast dat kostenbeheersing via massaontslagen volgens werkgevers de enige optie was. Met het grootste aantal stakingen en de felste arbeidsconflicten uit de naoorlogse Nederlandse geschiedenis tot gevolg (Van der Velden, 2004). 
Op 13 januari 1976 hing het grootbedrijf de kat voor het eerst de bel om. In een 'Open brief van bezorgde ondernemingsleiders' in het NRC Handelsblad spraken de bestuursvoorzitters van AKZO, AMRO Bank, Nationale Nederlanden, Philips, RSV, Unilever, Shell, Stork en Hoogovens hun afschuw uit over het motto van het kabinet-Den Uyl: 'spreiding van kennis, macht en inkomen'. Vriendelijk doch dringend vroegen de bestuursvoorzitters meer aandacht voor de aanbodzijde van de economie: 'In het maatschappelijke debat is de belangstelling voor verdelingsvraagstukken bijna allesoverheersend geworden en worden de productieproblemen bijkans verwaarloosd. Alsof datgene wat verdeeld moet worden, vanzelf ontstaat en niet door voortdurende inspanning en slagvaardig reageren van alle betrokkenen moet worden verkregen.'

De ondertekenaars waren G.A. Wagner van Shell, G. Krayenhoff van AKZO, J.R.M. van de Brink van AMRO Bank, H.F. van den Hoven van Unilever, P. van Meeteren van Nationale Nederlanden, H.A.C. van Riemsdijk van Philips, F.O.J. Sickinghe van Stork, A. Stikker van RSV en E. van Veelen van Hoogovens. Het gezelschap achter deze open brief aan het kabinet strekte zich daarmee uit tot vrijwel alle segmenten van de Nederlandse economie. Financieel kapitaal trok eendrachtig op met industriekapitaal, maakindustrie met dienstensector, delfstofindustrie met metaalindustrie, en consumentenelektronica met voedingsmiddelen.

Of de brief de doorslag heeft gegeven, is onduidelijk. In ieder geval kondigde koningin Juliana in de troonrede van 1976 de ' 1 -procentregeling' van minister Duisenberg aan: 'De verzwaring van de druk van de collectieve lasten blijft binnen de gestelde norm van 1 procent van het nationale inkomen.' En ook al zou het nog tot midden jaren 80 van de vorige eeuw duren voor de collectieve lastendruk daadwerkelijk zou dalen, de 1-procentnorm van Duisenberg luidde het begin in van een schier oneindige reeks van 'ombuigingsoperaties', die tot op de dag van vandaag voortduurt: 'permanent austerity', zoals de Amerikaanse politicoloog Paul Pierson het doopte (Pierson, 2001).

Zes jaar na de brief, in het najaar van 1982, troffen aan de Wassenaarse keukentafel van mevrouw Van Veen in het diepste geheim oud-CHUbewindsman en VNO-voorzitter Chris van Veen en FNV-voorzitter Wim Kok elkaar om het hardnekkige werkloosheidsprobleem te bespreken. De uitkomst was het fameuze Akkoord van Wassenaar, dat loonmatiging tegen arbeidsduurverkorting ruilde. Met terugwerkende kracht is het een kantelpunt in de machtsverhouding tussen kapitaal en arbeid gebleken. Neigde de arbeidsinkomensquote er begin jaren 80 van de vorige eeuw nog naar om richting de 90 procent op te klimmen, vanaf 1982 is dat percentage met 
wat horten en stoten gedaald tot net onder de 8 o procent aan de vooravond van de crisis (Salverda, 1977; CPB, 2001; 2013).

Dertig jaar later blijkt het Akkoord van Wassenaar geen 'meesterzet', zoals Visser en Hemerijck in 1997 nog dachten, maar een paardenmiddel dat voor sommige sectoren van de Nederlandse economie veel minder gunstig heeft uitgepakt dan voor andere. Tegenover een sterk verbeterde concurrentiepositie van de exportsector, resulterend in een scherp gestegen overschot op de handelsbalans (11 procent inmiddels) en een al even fors gegroeid spaaroverschot van het Nederlandse bedrijfsleven, staan al jaren slinkende koopkracht voor Nederlandse huishoudens en dalende afzetmogelijkheden voor het meer van de binnenlandse sector afhankelijke MKB - de grote afwezige in zowel 'de brief van negen' als in de lijst met ondertekenaars van het Akkoord van Wassenaar (zie Knot, 2013).

Ondanks forse groei van het aantal tweeverdieners (vanaf de tweede helft van de jaren 80 van de vorige eeuw) en vermogensaanwas in de vorm van opstuwende huizenprijzen (vanaf de tweede helft van de jaren 9o) kon de koopkracht van Nederlandse huishoudens geen gelijke tred houden met de inflatie. Sinds 2000 zijn de huishoudelijke bestedingen als aandeel van het bbp gedaald van $5^{0}$ naar 44 procent. En zeven jaar na de crisis is de reële koopkracht van Nederlandse huishoudens teruggevallen naar het niveau van 2001. Bovendien laat de laatste meerjarenraming van het Centraal Plan Bureau $(\mathrm{CPB})$ zien dat doorzettende economische groei zich niet vertaald in stijgende koopkracht (CPB, 2016).

Net als in Spanje, Ierland, het VK en de VS is dalende koopkracht door loonmatiging in Nederland gecompenseerd door private vermogensaanwas te stimuleren. Of het nu uit gelijkheidsoverwegingen was, uit hoofde van een neorepublikeinse ideologie (de 'ownership society' van Clinton en Bush), omdat eigen woningbezitters zogenaamd meer aandacht aan woning en buurt zouden besteden dan huurders, of uit inkomenspolitieke overwegingen, feit is dat in alle genoemde landen vanaf de jaren 90 beleid is ontwikkeld om het eigen huizenbezit te stimuleren en burgers deelgenoot te maken van de waardegroei van vastgoed.

Aan de aanbodzijde door subsidiëring van de bouwsector, decentralisering van het ruimtelijk ordeningsbeleid en door woningbouwcorporaties te stimuleren sociale huurwoningen te verkopen aan bewoners. En aan de vraagzijde door fiscale stimulering van eigen woningbezit, financiële innovatie en, vooral, aanzienlijke verruiming van de bancaire leenvoorwaarden.

In de internationale literatuur staat het bekend als de 'democratisering van schuld' (Ertürk et al., 2007) of 'privatisering van keynesiaanse vraagstimulering' ('privatized Keynesianism', Crouch, 1999): omdat de staat door 
de grote schuldpositie die zij uit de jaren 80 had geërfd in de jaren 90 van de vorige eeuw en in de eenentwintigste eeuw niet meer bij machte is om huishoudens via contra-cyclisch begrotingsbeleid tegen de economische conjunctuur te beschermen (volgens klassiek Keynesiaans recept: meer uitgeven als het economisch tij tegenzit, minder als het meezit), stelt de overheid huishoudens in staat om dat via schuld zelf te doen (zie ook Streeck 2013). Als de welvaartsgroei door loonmatiging achterblijft, kan het bestedingspatroon door het verzilveren van vermogensaanwas zodoende desondanks op peil blijven. De impliciete aanname achter deze beleidsoplossing is dat er sprake is van een eeuwige stijging van huizenprijzen zonder dat er zich pijnlijke 'correcties' voordoen, zoals in 2008 gebeurde en eerder, in 1978, was gebeurd. Doen die correcties zich wel voor, dan ligt een geniepige recessie op de loer.

Sinds de crisis is er steeds meer aandacht voor de relatie tussen private schuldgroei, huizenzeepbellen, binnenlandse consumptie en macro-economische effecten. Een econometrische studie van Reuven Glick en Kevin Lansing toont aan dat de landen van de Organisatie voor Economische Samenwerking en Ontwikkeling (OESO), waar tussen 1995 en 2007 de hypotheekschulden het snelste groeiden, ook de landen zijn waar, toen de onvermijdelijke correctie van de huizenprijzen eenmaal plaatsvond, de binnenlandse bestedingen het hardst zijn ingestort en de recessie na de financiële turbulentie van 2008 ook het diepste was en het langste duurde (Glick en Lansing, 2010).

In House of Debt hebben Atif Mian en Amir Sufi dit inzicht uitgewerkt tot een economische theorie, de 'levered-loss theory': hoe hoger de private schulden, hoe eerder huishoudens 'onder water' komen te staan, hoe meer ze snijden in hun uitgaven, hoe dieper de recessie (Mian en Sufi, 2014). En hoe groot de schuldaanwas in de VS ook was, hij was groter in Denemarken, Noorwegen, het VK, Spanje en Portugal. En hoe scherp de huizenprijzen in de VS ook zijn gestegen, de stijging was scherper in Denemarken, Noorwegen, het VK, Spanje en Portugal. En hoe dramatisch de daaropvolgende ineenstorting van gezinsbestedingen in de VS ook was, zij was dramatischer in Denemarken, Noorwegen, het VK en Spanje.

En in Nederland. Ook hier is sinds de jaren 90 het eigen woningbezit fors gestegen: van 35 procent van de woningvoorraad eind jaren 70 naar 43 procent eind jaren 80 en 56 procent in 2012. Ook hier zijn sinds de jaren 90 de leenvoorwaarden versoepeld. Ook hier hebben banken op grote schaal securitisatie gebruikt als financieringsbron. Ook hier zijn de huizenprijzen meerdere malen over de kop gegaan. En ook hier hebben huishoudens zich daardoor steeds dieper in de schulden gestoken. 
Figuur 5.4 Stijging hypotheekschulden in $\mathrm{x} €$ miljard

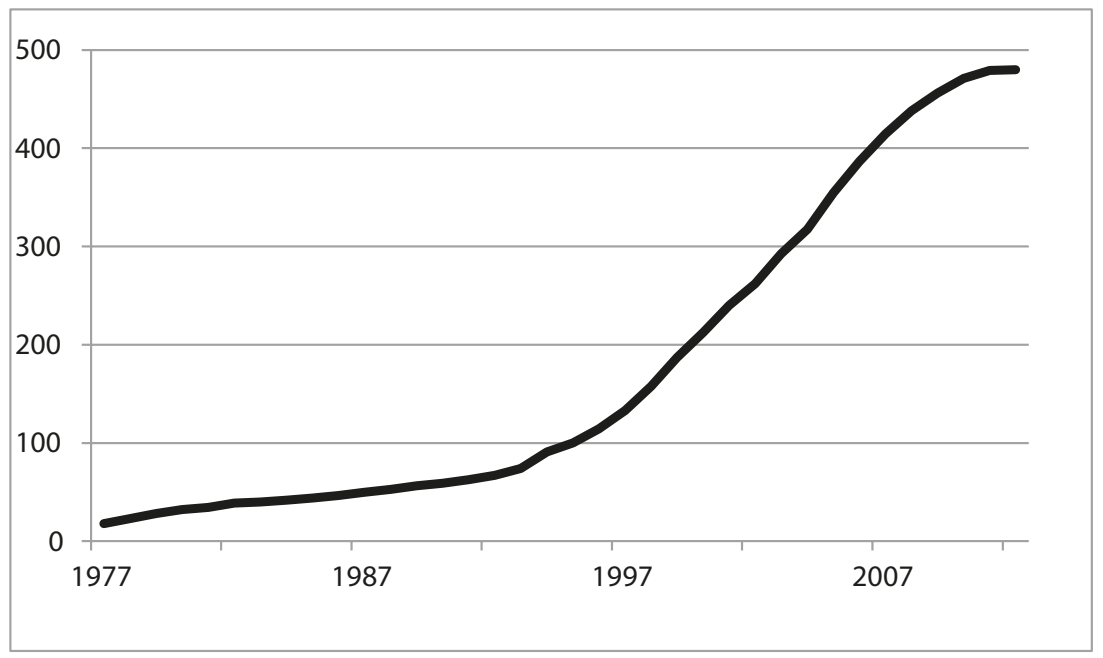

Bron: DNB, vermogenscomponenten van Nederlandse huishoudens, Tabel 11.1, http://www. statistics.dnb.nl/index.cgi?lang=nl

Het resultaat was ernaar, zoals figuur 5.4 laat zien. Sinds 1995 zijn de hypothecaire schulden letterlijk geëxplodeerd. Bedroegen die midden jaren 90 van de vorige eeuw nog pakweg $€ 100$ miljard, vijftien jaar later was dat bedrag verzesvoudigd, naar $€ 65^{2}$ miljard (eind 2012), 105 procent van het bbp. Daarmee gelijkop ging de explosieve groei van bancaire balansen. Van tweemaal het bbp in 1995 naar vijfmaal het bbp in 2008.

De parlementaire onderzoekscommissie onder leiding van D66-Kamerlid Verhoeven, die in 2013 een uitmuntend rapport opstelde over de Nederlandse huizenzeepbel, legde de oorzaak eenduidig bij de banken, die ruimere leenvoorwaarden afdwongen (vooral het meetellen van een tweede inkomen in 1994) en nieuwe, risicovolle hypotheekvormen bedachten: 'Hierdoor daalde in de periode 1996-2008 het percentage lineaire en annuïteitenhypotheken (en levensverzekeringen) van 40 procent naar circa 18 procent en nam het aantal beleggings- en met name aflossingsvrije hypotheken sterk toe. Het aandeel van deze hypotheekproducten steeg van 10 procent in 1996 tot circa 60 procent in 2008' (Tijdelijke Commissie Huizenprijzen, 2013, p. 28).

Combineer dat met financiële innovatie aan de passivazijde van de bankbalans - het securitiseren (verpakken en doorverkopen) van hypothecaire leningen, dat banken toegang gaf tot een schier onuitputtelijke bron van financiering in de vorm van een interbancaire markt waar Nederlandse securitisaties gretig als risicovrij onderpand aftrek vonden, en dat DNB vanaf 
1997 oogluikend en vanaf 2003 formeel toestond - en zie een geldmachine van ongekende omvang.

Ga maar na: bij financieringskosten van pakweg 1 procent en gemiddelde hypotheektarieven van 4 procent bedraagt de rentemarge op hypothecaire kredieten zo'n 3 procent. Op een hypotheekportefeuille van $€ 650$ miljard betekent dat een inkomstenstroom van bijna $€ 20$ miljard per jaar. Afgezet tegen operationele bancaire baten van $€ 15$ miljard, $€ 7,3$ miljard en $€ 13$ miljard in 2013 voor respectievelijk ING, ABN AMRO en Rabobank, betekent dit dat bijna 60 procent van de bancaire inkomsten afkomstig is van hypothecaire leningen. En dat zo goed als risicovrij: sinds 1993 valt een groeiend deel van de verstrekte hypotheken (driekwart in 2012) onder de Nationale Hypotheek Garantie (NHG) en is het wanbetalingsrisico daarmee voor de staat.

En dus is het evident waarom banken niets liever deden dan hypotheken verstrekken. Waarom hypotheken de grootste post op de balansen van de Nederlandse grootbanken zijn: $€ 209$ miljard op een bancaire balans van € 670 miljard bij Rabobank, € 290 miljard (Nederlandse en buitenlandse hypotheken) op een balans van $€ 88$ o miljard bij ING en $€ 150$ miljard op een balans van $€ 372$ miljard bij ABN AMRO. Waarom bankiers, (bank)economen en makelaars ook na de crisis bij hoog en bij laag volhouden dat Nederland geen huizenzeepbel heeft gekend

\section{Figuur 5.5 Stijging huizenprijzen $(2010=100)$}

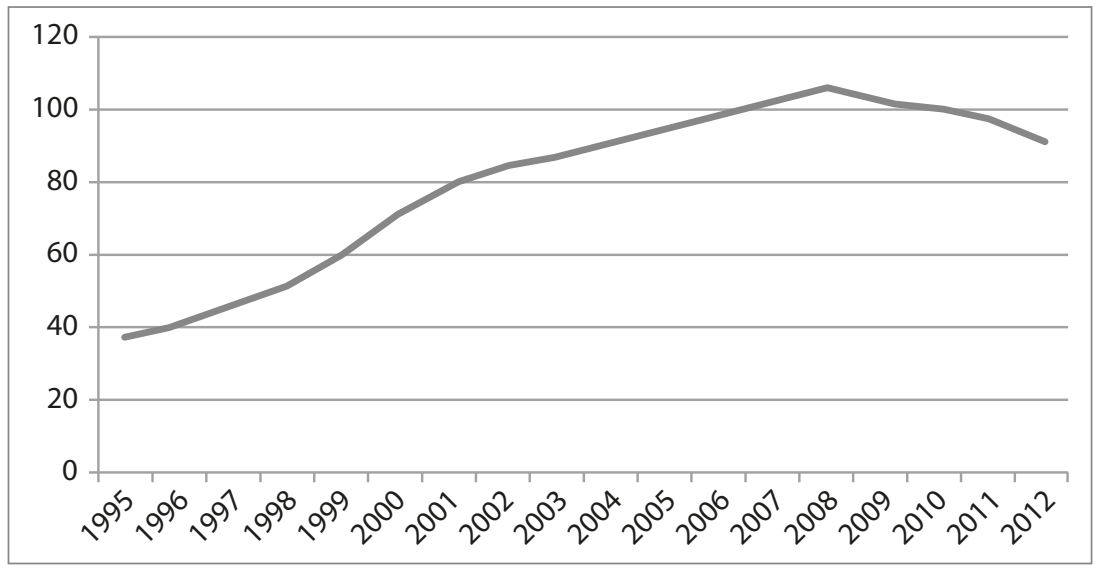

Bron: CBS, Statline, Bestaande koopwoningen, verkoopprijzen, prijsindex 2010=100, http://statline. cbs.nl/StatWeb/publication/?PA=81884NED 
omdat de 'fundamentals' in orde zouden zijn en Nederland gevrijwaard is gebleven van Spaanse spookvilla's en Ierse spookdorpen. En waarom de hypotheekrenteaftrek nog altijd als voornaamste boosdoener wordt aangewezen en niet de soepele leenvoorwaarden van banken, terwijl deze fiscale faciliteit al sinds 1893 bestaat en ook andere landen die kennen, waardoor levensgroot vragen opdoemen als: waarom hier en waarom nu?

Daar kwam bij dat door een restrictief ruimtelijk ordeningsbeleid het woningaanbod nauwelijks meeademde op toenemende vraag, terwijl door soepele leenvoorwaarden de wachtrij voor de beperkte voorraad beschikbare woningen alleen maar langer werd. De gevolgen laten zich raden: huizenprijsstijgingen van $25^{\circ}$ (eengezinswoningen) tot $35^{\circ}$ (appartementen) procent tussen 1995 en 2008, zoals figuur 5.5 illustreert.

Voordelig voor wie vooraan in de rij stond. Omdat het onderpand jaar op jaar met sprongen in waarde steeg, was verhuizen een feest. De immer stijgende huizenprijzen transformeerde de woning als vanzelf in een beleggingsobject en de bewoner in een speculant; de gebruikswaarde werd ondergeschikt aan de ruilwaarde. Met alle bestedingseffecten van dien. Alles bij elkaar opgeteld (makelaars, bouwsector, banken, notarissen, doe-het-zelfoutlets, designwinkels, klusjesmannen, aannemers, projectontwikkelaars, gemeentelijke grondbedrijven, keukenontwerpers, naaiateliers, meubelboulevards, verfwinkels, parketleggers, kraanverhuurders, betonstorters, plus de tweede-orde-effecten in de vorm van de consumptie en belastinginkomsten die het genereerde) is pakweg een derde van de cumulatieve economische groei van de acht paarse jaren (9 procent van 28,2 procent) en een kwart van de groei tijdens het Balkenende-tijdperk (3,5 procent van 14,6 procent) vastgoedgedreven.

Maar nadelig voor wie achteraan in de rij stond. Wie tussen 2004 en 2008 een woning kocht, keek tegen oververhitte vastgoedprijzen aan die banken en hypotheekbemiddelaars in de gekste bochten dwongen om nog hypothecaire leningen te kunnen verstrekken en huishoudens met veel te veel schuld en dus veel te veel risico belastten. Van de 4,6 miljoen huishoudens in Nederland met een hypothecaire schuld kijken er op dit moment zo'n 1,3 miljoen aan tegen een negatieve waarde. Dat is een derde van alle huishoudens, meer dan de kwart die in de VS op het dieptepunt van de hypotheekcrisis onder water stond. En waren het in de VS overwegend laaggeschoolden aan de onderkant van de arbeidsmarkt die hun onroerendgoedvermogen zagen verdampen, in Nederland zijn het vooral de 45-minners die onder water staan. DNB heeft berekend dat van de leeftijdcohorten tussen de 25 
Figuur 5.6 Verdeling over- en onderwaarde

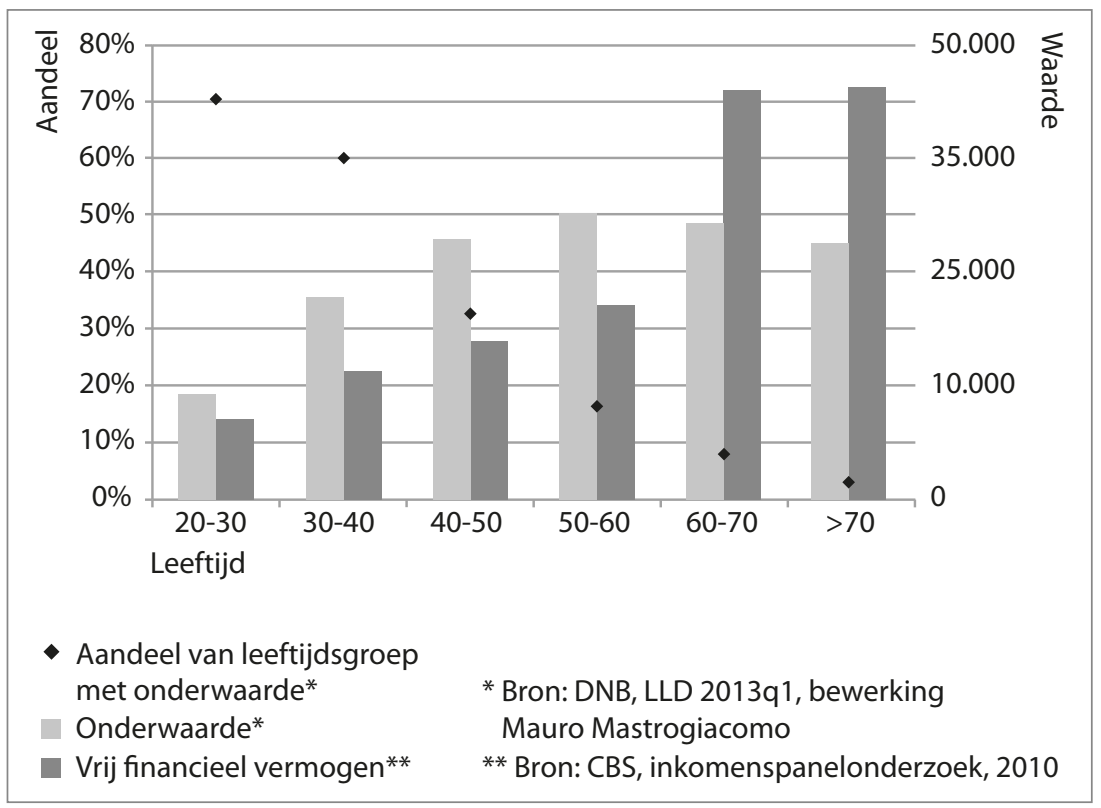

Bron: DNB, 2015

en 45 jaar rond de 60 procent tegen onderwaarde aanhikt, tussen de 45 en $5^{0}$ jaar is het percentage met onderwaarde en overwaarde min of meer in evenwicht, terwijl alles boven de 50 forse tot zeer forse (meer dan een ton) overwaarde heeft, zoals figuur 5.6 laat zien.

\section{Het gegijzelde mirakel}

Dat het kernprobleem private schulden zijn, klinkt echter nauwelijks door in het huidige beleidsdiscours, dat luidt dat Nederland op te grote voet heeft geleefd, de tering naar de nering moet zetten en dat het zoet pas na het zuur komt. De financiële schok van het najaar 2008 en de $€ 130$ miljard die de staat de Nederlandse banken heeft moeten toestoppen (zie website rekenkamer), zijn een voetnoot in de geschiedenis geworden die de meeste politici, anders dan burgers, allang weer zijn vergeten. Terwijl daardoor de staatsschuld in 2009 wel degelijk met bijna 20 procent van het bbp omhoog is gesprongen. 
De wederom uit de kast gehaalde 'participatiesamenleving', het hameren op uit de klauwen gegroeide zorgkosten, een Miljoenennota (in 2014) die met factoïds strooit dat de Nederlandse staat per dag $€ 55$ miljoen meer uitgeeft dan hij ontvangt, het gebruik van de term 'zondegeld' ter aanduiding van de rentelasten op de staatsschuld (Ministerie van Financiën, 2013, p. 20) - het suggereert een probleemanalyse die de oorzaak van de crisis legt bij verwende burgers, die te veel zorg, bescherming en opvang vragen en daar te weinig voor willen betalen, en bij slappe politici, die deze verwende burgers te veel naar de mond hebben gepraat (zie Engelen 2014: 125).

Dat beleidsmakers niet snappen dat gelijktijdige balansverkorting door huishoudens, banken en overheid de binnenlandse economie in recessie heeft gestort, heeft alles te maken met het onvermogen om in te zien dat de oorzaak van de excessieve balansgroei van banken en huishoudens van vóór de crisis gelegen is in huishoudelijke verarming door loonmatiging ten faveure van de Nederlandse exportsector. Sterker, de beleidsconsensus is dat het Nederlandse economische herstel zal beginnen bij de exportsector en dat het vanwege weglekeffecten vergeefse moeite is om via loonstijgingen en/of lastenverlichtingen de binnenlandse bestedingen aan te zwengelen.

Niet alleen gaat deze consensus voorbij aan het feit dat het overschot op de handelsbalans al ongekend groot is en eerder een indicatie is van macro-economische onevenwichtigheden, en dus eerder een probleem dan een oplossing is. En dat de Nederlandse economie ondanks haar grote internationale openheid nog altijd ruim tweederde van haar bbp binnenslands genereert en er dus grenzen zijn aan het 'weglekeffect'. Bovendien gaat zij voorbij aan het feit dat de hele Eurozone momenteel binnenlandse koopkracht opoffert voor herstel van het concurrentievermogen, en de effectieve vraag in de Eurozone dus nog lange tijd anemisch zal blijven.

Belangrijker is dat deze consensus de Nederlandse beleidselite ervan ontslaat om de ongemakkelijke vraag te stellen of er niet sprake is geweest van excessieve loonmatiging en er niet in navolging van bijvoorbeeld de Duitse Bundesbank of de Japanse regering zou moeten worden gepleit voor loonstijging. En als die vraag al gesteld wordt, dan schielijk, voorzichtigjes en onder verzekering dat dit geen algemene looneis kan impliceren - zie uitlatingen van DNB-president Klaas Knot (Knot, 2013; De Boer, 2015).

Dat dit een ongemakkelijke vraag is, heeft alles te maken met de specificiteit van de Nederlandse geschiedenis. Diep in het DNA van Nederlandse bestuurders, de Nederlandse instituties en de morfologie van Nederland liggen namelijk eeuwen van primitief mercantilisme opgetast (Gelderblom, 2015). Werp een blik op de Amsterdamse grachtengordel of op de Nederlandse landkaart, om te zien dat deze stad (en dit land) wat geografische ligging 
betreft was voorbestemd om zich te ontwikkelen tot een entrepot-economie. De grachtengordel ontpopte zich in de zeventiende eeuw op basis van de simpele handelsstrategie van goedkoop inkopen en duur verkopen en in de tussentijd opslaan in pakhuizen, tot een overslagplaats en, later, een informatieverwerkingsmachine en logistiek-distributief centrum zonder weerga (Lesger, 2001).

Er loopt een rode draad van deze Gouden Eeuw-ervaring naar het neomercantilisme (alles voor de exportsector, ongeacht de kosten) van de huidige beleidselite. Nederland is een grote draaischijf in internationale productienetwerken: voor belasting- en toezichtmijdend kapitaal (Amsterdamse brievenbusmaatschappijen), voor informatie (uitgeverijen), voor gas (Eemshaven), voor bloemen (Aalsmeer), voor steenkool (Rotterdam, Amsterdam), voor de aansturing van multinationale ondernemingen (holdings), voor vlees (het slachthuis van Europa) en voor goederen (Rotterdam, Schiphol).

In de loop der eeuwen heeft deze handelskapitalistische geschiedenis een hechte vervlechting van economische en bestuurlijke elites veroorzaakt, en geleid tot een land dat grotendeels is toegesneden op de belangen van de exportsector. Deels is dat een uitvloeisel van geografische ligging (aan de monding van drie grote Europese rivieren), deels van doelbewust ontwikkelde infrastructuur (havens, waterwegen, ict-kabels, vliegvelden, wegen) en deels van pad-afhankelijke institutiebouw (aandelenbeurs, kapitaalgedekte pensioenfondsen, consolidatie bancaire sector, fiscale concurrentie). Geografie, verzonken kosten in de vorm van investeringen in infrastructuur en instituties, alsmede de politieke belangen die zich rond deze handelskapitalistische geschiedenis hebben geplooid, zijn door de eeuwen heen de belangrijkste causale mechanismen achter de succesvolle reproductie ervan geweest (Prak en Van Zanden, 2013).

Arbeidsmarkt, fiscaliteit, exportbevordering, industriebeleid, topsectoren, onderwijsbestel, wetenschapsbeleid, infrastructuur - het stond altijd al en staat meer dan ooit ten dienste van de spreekwoordelijke BV Nederland. Dat het belang van het grootbedrijf ondertussen steeds minder samenvalt met dat van Nederland, dat het grootbedrijf hier te lande (en elders) steeds minder belasting betaalt (8 procent van het bbp in 2000 tegen 5,6 procent in 2012) (Eurostat, 2014), dat het Nederlandse grootbedrijf steeds meer banen in het buitenland en steeds minder banen in Nederland genereert (tussen 1985 en 2012 daalde de werkgelegenheid van de vijf grootste multinationals in Nederland met 74 (!) procent) (Stam, 2014), dat buitenlandse multinationals in Nederland vooral laagbetaalde distributiebanen creëren (CBS, 2015), dat het grootbedrijf überhaupt steeds meer statenloos is geworden, dat allemaal 
is kennelijk politiek irrelevant. Dat loonmatiging bedrijven lui maakt, een vorm van concurrentievervalsing is, de belangrijkste oorzaak van de eurocrisis is, en funest is voor de binnenlandse bestedingen, kennelijk al evenzeer (zie Vergeer en Kleinknecht, 2011).

Deels is het de uitkomst van de toevalligheden van de Nederlandse geschiedenis en deels van de zeer invloedrijke lobby van werkgeversorganisatie VNO-NCW. Het gebouw aan de Bezuidenhoutseweg waarin deze organisatie huist, torent niet alleen symbolisch boven de regeringsgebouwen uit. En het is geen toeval dat haar voormannen jaren achtereen door de Volkskrant zijn uitgeroepen tot invloedrijkste bestuurders van Nederland. Belangrijker is dat de tegeltjeswijsheid dat 'wat goed is voor de exportsector, goed is voor Nederland' ('We zijn nou eenmaal een handelsnatie', '70 procent van onze welvaart halen we uit het buitenland', 'koopman, dominee', 'Nederland exportland' - dat werk) gegrift staat in het onderbewustzijn van de bestuurlijke elite.

\section{Het gefragmenteerde mirakel}

Maar er is meer aan de hand dan een economische beleidsagenda die nu al drie decennia wordt gegijzeld door de belangen van het Nederlandse industrie- en handelskapitaal. Terwijl de industriële elite bij monde van de zelf niet-onbemiddelde Cees van Lede (oud-bestuurder AkzoNobel), Jan Timmer (oud-bestuurder Philips) en Karel Vuursteen (oud-bestuurder Heineken) in september 2007 in het tv-programma Netwerk mopperig haar beklag deed over de exorbitante bedragen die hun buitenlandse opvolgers vroegen - Vuursteen: 'Dit is niet normaal meer, er is geen enkele relatie tussen prestatie en de beloning', Van Lede: 'Als we niet oppassen krijgen we huurlingen aan de top van het bedrijfsleven', Timmer: 'De enige loyaliteit die er nog is, is aan geld' - maakte de financiële elite zich op voor totale onthechting, fraai geïllustreerd door het nieuwe (en inmiddels alweer verlaten) hoofdkantoor van de (inmiddels alweer ontvlochten) ING Holding langs de A1o - bijgenaamd 'de schoen', maar meer weg hebbend van een aluminiumkleurige zeppelin die met wat wankele ankers aan het Nederlandse grondgebied is bevestigd en op het punt staat weg te vliegen.

Onderzoek van Heemskerk en Fennema leert dat het old boys network (denk: de tweehonderd van Mertens) al langer uit elkaar aan het vallen is. Door de internationalisering van beursgenoteerde Nederlandse ondernemingen zijn raden van bestuur en raden van commissarissen in toenemende mate gelardeerd met bestuurders van buiten de alumniverenigingen van 
de Nederlandse economie- en rechtenfaculteiten. Voor de crisis had meer dan de helft ( 52 procent) van de bestuurders van de ondernemingen uit de AEX-25-index een andere dan de Nederlandse nationaliteit (Heemskerk, 2007; Heemskerk en Fennema, 2008).

Er zijn echter grote verschillen in de mate van internationalisering tussen bedrijven. Op Shell, Reed-Elsevier en Unilever na, die van oudsher een dubbele nationaliteit bezitten, is het merendeel van de beursgenoteerde maakindustrieën wat cultuur betreft overwegend Nederlands en wat oriëntatie betreft Europees. Het aantal buitenlandse bestuurders is beperkt, de voertaal is meestal Nederlands, het bestuurscentrum en de onderzoeks- en ontwikkelingsafdeling zijn stevig in Nederland verankerd, de meerderheid van de werknemers werkt in Nederland en het merendeel van omzet en winst wordt in Nederland en de naaste buurlanden behaald.

Dat gold tot voor de crisis in veel mindere mate voor de grote financiële instellingen. Met meerdere thuismarkten, sommige aan de andere kant van de oceaan en met activiteiten over de hele wereld, was de vereenzelviging met Nederland veel minder sterk. Neem het verschil in omvang van ABN AMRO vóór en na de overname: een balans van iets meer dan 1000 miljard euro voor de overname tegen 372 miljard euro nu (2013) - het saldo zijn de buitenlandse activiteiten van ABN AMRO die naar Santander en RBS gingen. Oftewel, ruim tweederde van 'De Bank' bevind zich buiten Nederland. En datzelfde was in meer (ING) of mindere (Rabobank) mate het geval bij de overige Nederlandse grootbanken.

Mede op instigatie van de toezichthouder, De Nederlandsche Bank, die zich in toenemende mate had ontpopt tot voorzanger van de Nederlandse bancaire sector, waren sinds de jaren zeventig de wettelijke schotten tussen de verschillende financiële activiteiten (zakenbankieren, hypotheekverstrekken, verzekeren) de een na de ander opgeheven, en waren de wettelijke beperkingen op grensoverschrijdend kapitaalverkeer verwijderd. Daarmee bevond Nederland zich aan het voorfront van de financiële internationalisering en waren Nederlandse grootbanken zo goed mogelijk toegerust om als winnaars uit de Europese en mondiale consolidatieslag (in consultancykringen 'global endgame' geheten) te komen die de toezichthouder al in de jaren zeventig voorzag (Prast en Lelyveld, 2004). Het gevolg was een snelle consolidatie van de Nederlandse bancaire sector en een zeer vroege internationalisering van Nederlandse grootbanken.

Dat het geldkapitaal bij zijn nationale en internationale expansie door politiek en toezichthouder geen strobreed in de weg werd gelegd kwam ook door de afwezigheid van politieke tegendruk. Een politieke economie met een ontketende financiële sector is namelijk ook een politieke economie 
met een immense pensioenpot en een enorme huizenzeepbel. Via de pensioenfondsen, waarbij 95 procent van de werkenden is aangesloten, zijn de meeste Nederlanders, of ze dat nu willen of niet en of ze zich daar nu van bewust zijn of niet, steeds vertrouwder geraakt met de argumenten voor de maximalisatie van aandeelhouderswaarde. Weinig zo vanzelfsprekend als de pensioenbestuurder die ten overstaan van een kritische Zemblajournalist de dooddoener debiteert dat hij maar één plicht heeft, en dat is zorgen voor een zo hoog mogelijk rendement voor zijn deelnemers, als hem gevraagd wordt waarom zijn pensioenfonds nog steeds in clusterbommen belegt.

In Nederland is zo de typisch corporatistische coalitie van werknemers en (verlichte) bestuurders van de jaren $5^{\circ}$ en 6o, in de jaren 70, 80 en 90 geleidelijk uit elkaar gevallen en in de eenentwintigste eeuw vervangen door een 'postmoderne', gefinancialiseerde coalitie van werknemers en aandeelhouders. De beheerders van het pensioenspaargeld, ABP en PGGM voorop, hebben zich sinds de jaren go van de vorige eeuw meer en meer ontpopt tot voorvechters van meer zeggenschap voor aandeelhouders - zelfs als die botst met het bevoogdende paternalisme van een werknemersvriendelijke bedrijfsleiding.

Bovendien heeft de wettelijk verankerde positie van vakbondsvertegenwoordigers in het bestuur van deze fondsen geleid tot een vakbeweging die steeds minder bereid is op te komen voor de belangen van werkenden als deze botsen met die van gepensioneerden - een proces dat wordt versterkt door de vergrijzing van het ledenbestand van de Nederlandse vakbeweging. Niet de SER of de Stichting van de Arbeid is de eigenlijke machtsbasis van een vakbeweging in verval (nog maar 21 procent van de Nederlandse werknemers is lid), maar de pensioenfondsbesturen. Hoe anders het kopen van een substantieel deel van de emissie van Fortis in mei 2007 door het ABP te verklaren, waarmee Fortis (en daarmee het $A B P$ ) de overname van $A B N$ AMRO financierde? Of hoe anders de bereidwilligheid van de vakbeweging te begrijpen om jarenlang in te stemmen met de wens van werkgevers om de lonen te matigen, terwijl het FNV wel bereid was zichzelf op te blazen over verzet tegen verhoging van de pensioengerechtigde leeftijd, zoals in 2011 bijna gebeurde?

Dezelfde intellectuele gijzeling heeft zich voorgedaan bij de banken. Wat goed is voor banken, is inderdaad goed voor Nederland en dus voor burgers, als diezelfde burgers met behulp van schijnbaar vrijgevige banken collectief een huizenzeepbel van ongekende proporties aan het blazen zijn. Wat een buitenkansje is voor degene vooraan in de rij, is bittere noodzaak voor degene achteraan: lenen, lenen en meer lenen. En hoe meer deelnemers, 
hoe groter het belang om door te gaan op de ingeslagen weg. Huidige huizenbezitters kunnen hun overwaarde immers alleen verzilveren als er voldoende nieuwe kopers zijn. En nieuwe kopers vooronderstelt nieuwe, nog hogere hypothecaire leningen.

Zo konden de banken jarenlang rekenen op massale electorale protesten als toezichthouders of politici voorzichtig iets probeerden te doen wat het spel zou kunnen bederven. Het is dezelfde logica die ervoor heeft gezorgd dat er in anderhalve eeuw nauwelijks iets aan de hypotheekrenteaftrek is gedaan, die er voor zorgt dat aanbevelingen van de president van De Nederlandse Bank om de maximale loonruimte voor huishoudens verder in te perken door de politiek worden weggehoond (Financieel Stabiliteitscomité 2015), die er voor zorgt dat er door de Europese Commissie hard wordt gewerkt aan het optuigen van een Europese markt voor verpakte hypotheekprodukten (Engelen en Glasmacher 2015a;2015b) en die er nu, zeven jaar na de crisis, voor zorgt dat banken nog altijd met fluwelen handschoenen worden aangepakt - het zou eens ten koste kunnen gaan van de hypothecaire kredietverlening! Financialisering creëert haar eigen achterban (Fuller, 2015; Aalbers en Engelen, 2015).

\section{Conclusie}

Kort en goed: tussen 1982 en 2008 zingt de financiële elite zich meer en meer los van het Nederlandse politieke bestel en daarmee van de facties die daar hun machtsbasis hebben. Tot de Interne Markt en de lobby om het Verdrag van Maastricht en de Euro trekken het industrie- en handelskapitaal aan de ene kant en het geldkapitaal aan de andere nog gezamenlijk op. Daarna valt het old boys network uiteen in een loonmatigingscoalitie, gecentreerd rond VNO-NCW en het exporterende grootbedrijf, en een schuldgroeicoalitie van Nederlandse grootbanken die van nationale toezichthouders niets te vrezen en van de Haagse politiek niets meer te verwachten heeft (want alles al heeft gekregen) en die haar politieke activiteit dus meer en meer verlegt naar Brussel, Bazel (Bank voor Internationale Betalingen - BIB), Londen, Washington en New York, waar de beslissingen over de vormgeving van het internationale financiële stelsel in het zog van de financiële internationalisering meer en meer zijn komen te liggen.

In loonmatiging zijn banken - met ook tijdens de crisis cao's van 125 procent van de salarissen bij vergelijkbaar opleidingspeil in de rest van de economie - nooit zeer geïnteresseerd geweest. Als er veel transacties zijn, dan groeit het aantal bankiers, zijn er weinig transacties, dan krimpt 
hun aantal - dat is het impliciete sociale contract. Publieke uitlatingen van banken over het loonbeleid in Nederland zijn sinds de deelname van AMRO-bankier Van den Brink aan de commissie-Wagner I dan ook op de vingers van één hand te tellen.

Dit verlies van vertrouwdheid van politieke en industriële elite met de financiële elite verklaart in belangrijke mate de onwetendheid van diezelfde elite over de verregaande afhankelijkheid van de Nederlandse economie en samenleving van datzelfde bankwezen. Dat het zolang duurde voordat de politiek ontdekte en erkende dat Nederland door eigen toedoen in een majeure balansrecessie was gestort, is daar een indicatie van. Pas in maart 2016 nam de minister van Financiën van het kabinet Rutte 2, PvdA-er Jeroen Dijsselbloem, in een uitzending van Buitenhof het woord 'balansrecessie' in de mond om het macroeconomische lot van Nederland mee aan te duiden. Het was een impliciete erkenning dat het aggressieve begrotingsbeleid dat ook onder zijn verantwoordelijkheid heeft plaatsgevonden, de Nederlandse economie meer heeft geschaad dan nodig is geweest.

Net als het gebrek aan belangstelling van de Kamer, toen in 2003 een wetsvoorstel voorlag om 'stille cessie' toe te staan, de wettelijke verankering van de mogelijkheid om hypotheken te verpakken en door te verkopen aan derden zonder debiteuren (huishoudens) daarvan op de hoogte te stellen. Dat was daarvoor gedoogd en werd nu officieel toegestaan, met een forse groei van het aantal securitisaties tot gevolg: tussen 1996 en 2003 waren er 77 securitisaties in de markt gezet, tussen 2003 en 2008 zouden dat er 130 worden. Kees Vendrik van GroenLinks (tegenwoordig Algemene Rekenkamer) was destijds tot zijn eigen verbijstering de enige financieel specialist die aanwezig was bij het 'debat'. En de Memorie van Toelichting bij het wetsartikel bevatte passages die een-op-een waren overgenomen uit lobbymateriaal van de Nederlandse Vereniging van Banken (Wester, 2009).

Het gevolg was dat na het uitbreken van de crisis in 2008 werd teruggegrepen op vertrouwde, maar faliekant verkeerde economische narratieven, alsof het 1982 was, niet 2008: bijgeschaafd, ingefluisterd en van wetenschappelijke legitimiteit voorzien door een kaste van 'gelijkgeschakelde' beleidseconomen met nauwe relaties tot het $\mathrm{CPB}$ en het ministerie van Financiën. En zo bleef het verhaal - ondanks de ravage die de financiële crisis had aangericht - hetzelfde: meer marktwerking, meer loonmatiging, meer schuld, meer financialisering, meer securitisatie en meer mercantilisme.

Als je een economie zou moeten ontwerpen die maximaal kwetsbaar is voor financiële schokken, dan zou je zo ongeveer op de Nederlandse economie anno 2008 uitkomen. 
Het is dan ook niet bedacht, maar ontstaan. Onbewust, onbedoeld en lange tijd ongezien. Simpelweg omdat het kon: Nederland beschikte nu eenmaal over een financieel waterhoofd dat kon worden gebruikt om banken op te pompen, huishoudens verslaafd te maken aan schuld en huizenzeepbellen te blazen - zowel hier als elders. Omdat banken er vorstelijk aan konden verdienen. Omdat het zo prachtig in de neoliberale kraam paste waarover economen zulke schitterende verhalen konden vertellen: minder staat, meer markt; minder collectief, meer individueel; minder dwang, meer zelfzorg - en het economische paradijs zou ons vanzelf toevallen. En omdat het perfect aansloot bij het levensgevoel van de jaren go: het 'je bent een dief van je portemonnee als je huurt en niet koopt' zong vijftien jaar lang rond op Nederlandse verjaardagsfeestjes.

Een land dat door een historisch ongeluk een corporatistische arbeidsmarkt, een Rijnlandse economie en een Scandinavische verzorgingsstaat paart aan een ontketende financiële sector, is nu eenmaal onherroepelijk een land met een gefragmenteerde elite. Met beleidsleren heeft het polderwonder en zijn keerzijde dan ook niet zo vreselijk veel van doen, in mijn ogen. Met institutioneel doormodderen - zo weten we een financiële implosie, twee bankennationalisaties, drie opeenvolgende recessies en vele kabinetten later - des te meer.

De totstandkoming van het wonderlijke groeimodel van Nederland een zeldzame combinatie van exportgedreven en schuldgedreven groei - is diepgeworteld in de geschiedenis van onze infrastructuur, in onze geografische locatie, in onze instituties en in de politieke coalities en de economische narratieven die zich daar in de loop der tijd omheen ontwikkeld hebben. Pad-afhankelijkheid en een zekere mate van determinisme zijn wat mij betreft om die reden belangrijker voor een goed begrip van de Werdegang van de Nederlandse politieke economie, dan de al dan niet vermeende rationaliteit van beleidsmakers waarop Visser en Hemerijck zo de nadruk leggen. Het is typerend voor het voluntaristische perspectief van Een Nederlands mirakel dat alles wat met pad-afhankelijkheid te maken heeft pas in de laatste zin van het boek wordt benoemd, in de vorm van een verwijzing naar Fortuna: de omstandigheden waar een beleidsmaker geen invloed op heeft, maar die wel het falen of slagen van zijn interventies bepalen. Wat meer aandacht voor Fortuna en wat minder voor Virtu had de auteurs kunnen behoeden voor een te groot geloof in het bestaan van 'bovennatuurlijke feiten'. 



\title{
$6 \quad$ Het pensioenmirakel ontleed
}

\author{
Functionaliteit en legitimiteit in het Nederlandse \\ pensioenstelsel
}

Natascha van der Zwan

\begin{abstract}
Elk jaar weer staan we in de top drie. De hele wereld kijkt jaloers naar ons dijkenstelsel. Toch kennen we problemen. Het waterpeil stijgt en de bodem klinkt in. En soms loopt het toch uit de hand. Hoe gaan we hiermee om?

Er komt geen discussie dat we al onze dijken willen vervangen naar een compleet ander stelsel. Zwakke plekken worden direct aangepakt en niet doorgeschoven naar toekomstige generaties of naar een nationale dijkendialoog.

Gingen we ook maar zo met ons pensioenstelsel om. Net als onze dijken behoort het tot de beste van de wereld. Maar er zijn ook zwakke plekken die we allemaal kennen. ${ }^{1}$
\end{abstract}

Al sinds jaar en dag wordt het Nederlandse pensioenstelsel in binnen- en buitenland geloofd als 'het beste stelsel ter wereld'. De lof voor het pensioenstelsel doet denken aan 'dat andere Nederlandse mirakel', dat door Jelle Visser en Anton Hemerijck in hun boek uit 1998 werd belicht. Hoewel het Nederlandse poldermodel met name geassocieerd wordt met gecoördineerde loononderhandelingen, is ook het pensioenstelsel een belangrijk onderdeel van het poldermodel. Net als andere sociale beleidsterreinen is pensioen, zowel de AOW als de arbeidsvoorwaardelijke pensioenen, onderwerp van centraal overleg tussen overheid en sociale partners. Daarnaast zijn sociale partners op decentraal niveau verantwoordelijk voor de invulling van de arbeidsvoorwaardelijke pensioenen. Ook spelen zij als bestuursleden van pensioenfondsen een belangrijke rol bij de uitvoering van de arbeidsvoorwaardelijke pensioenregelingen. Overleg en onderhandeling zijn dus belangrijke onderdelen van het pensioenbeleid binnen alle lagen van het pensioenstelsel, net als bij het arbeidsmarktbeleid dat door Visser en Hemerijck in hun boek werd beschreven.

1 Speech Kick van der Pol, voorzitter Pensioenfederatie, tijdens het Jaarcongres Pensioenfederatie, 6 november 2014, laatst bekeken 12 oktober 2015 via http://www.pensioenfederatie.nl/ Document/Evenementen/2014/Congres\%202014/Speech_KickvanderPol_congres_2014.pdf. 
Dat met het poldermodel ook op het gebied van pensioen goede resultaten worden geboekt, gold lange tijd als een gegeven binnen Nederlandse beleidskringen. Beleidsinstrumenten als de verplichtstelling en de doorsneepremie hebben bijgedragen aan 'een robuust pensioenstelsel, met een zorgvuldig gekozen balans van bescherming, doelmatigheid en solidariteit' (Kamerstuk 30413, 157). De financiële crisis heeft deze optimistische kijk op het pensioenstelsel echter aan het wankelen gebracht: veel pensioenfondsen zagen hun dekkingsgraden dalen en konden niet langer indexeren of moesten zelfs pensioenen korten. Sindsdien is het vertrouwen van de burger in de Nederlandse pensioenfondsen aanzienlijk gedaald en maken veel mensen zich zorgen over hun toekomstige pensioen (DNB, 2014). Plannen voor een verregaande hervorming van het Nederlandse pensioenstelsel, waaronder het vervangen van belangrijke elementen van collectiviteit en solidariteit door individueel maatwerk, werden in de zomer van 2015 door het kabinet aangekondigd.

Waarom staan de bouwstenen van 'het beste pensioenstelsel ter wereld' binnen Nederland momenteel ter discussie, ondanks de nationale en internationale waardering voor het stelsel? Wetenschappelijke beschouwingen op het corporatisme in het algemeen en het poldermodel in het bijzonder richten zich vaak op vragen van effectiviteit (de output van het stelsel) en representativiteit (de input) (vgl. Streeck en Crouch, 2006). Ook in het kader van de huidige pensioenproblematiek worden dergelijke verklaringen geopperd: zo zou de toegenomen afhankelijkheid van financiële markten de zekerheid van de arbeidsvoorwaardelijke pensioenen onder druk hebben gezet, terwijl de vergrijzing van de bevolking verdere kostenbesparingen noodzakelijk maakt. Daardoor zouden de sociale partners een stuk minder bewegingsvrijheid hebben om te onderhandelen over beleid. Deze bewegingsvrijheid wordt verder beperkt door een dalende bereidheid van werkgevers om risicodrager te zijn voor de arbeidsvoorwaardelijke pensioenen, alsmede door de afnemende representativiteit van de vakbeweging (Bovenberg, 2014). Dergelijke factoren worden niet alleen genoemd in het kader van het Nederlandse pensioenstelsel, maar ook voor diverse andere Europese landen (vgl. Casey, 2012).

In dit hoofdstuk betoog ik echter dat op input en output gerichte verklaringen niet afdoende zijn om het schijnbare verval van het pensioenmirakel te verklaren. In plaats daarvan richt ik me op de werking van het pensioenstelsel zelf, de zogeheten throughput. Ik betoog dat juist de politieke mechanismen die consensusvorming binnen het poldermodel bevorderen - een gedeelde normatieve visie, het ontwikkelen van een gemeenschappelijke probleemdefinitie en incrementele aanpassing van het beleidsrepertoire 
door overheid en sociale partners - er anno 2008 voor hebben gezorgd dat de fundamenten van het pensioenstelsel onder druk zijn komen te staan. Door zich te beroepen op de onvermijdelijkheid van externe ontwikkelingen waarmee het pensioenstelsel geconfronteerd wordt, hebben de partijen zichzelf effectief geïsoleerd van aansprakelijkheid voor het functioneren van het stelsel. Het gevolg is een discrepantie tussen de visie van de polderelite op de toekomstbestendigheid van het pensioenstelsel en die van de burger, die effectief is gemobiliseerd door critici van het stelsel. Hierdoor is politiek ruimte ontstaan voor nieuwe beleidsideeën, die op termijn de aard van het stelsel fundamenteel kunnen veranderen.

De opzet van dit hoofdstuk is als volgt. In de eerste paragraaf worden de belangrijkste elementen van het poldermodel nader uiteengezet op basis van de wetenschappelijke literatuur. Speciale aandacht wordt daarbij besteed aan Een Nederlands mirakel, Visser en Hemerijcks analyse van het Nederlandse poldermodel. Paragraaf twee zet het zogenaamde pensioenmirakel uiteen. Hier wordt aangetoond dat het idee van 'het beste stelsel ter wereld' rust op een verzameling corporatistische instituties met bijbehorend beleidsinstrumentarium (met name de verplichtstelling en de doorsneepremie) en een normatief kader van solidariteit, collectiviteit en betaalbaarheid. Paragraaf drie gaat vervolgens dieper in op de vraag hoe de partijen getracht hebben het pensioenmirakel in stand te houden in de nasleep van de financiële crisis. Dat de uitkomsten van dit proces verre van onvermijdelijk waren, blijkt uit de vierde paragraaf, waarin alternatieve ideeën omtrent de oorzaken en oplossingen voor de pensioenproblematiek besproken worden. In paragraaf vijf wordt ten slotte ingegaan op de vraag welke gevolgen deze ontwikkelingen hebben voor de toekomst van het Nederlandse pensioenstelsel.

\section{Corporatisme en consensus}

Toen Visser en Hemerijck (1998) het Nederlands corporatisme 'miraculeus' noemden, doelden zij op de economische opleving die Nederland doormaakte in de jaren 9o, in het bijzonder het terugdringen van de recordhoge werkeloosheid uit het voorgaande decennium. De auteurs weten die opleving aan het succes van het Akkoord van Wassenaar uit 1982, waarin werkgevers en vakorganisaties zich hadden verbonden aan loonmatiging in ruil voor meer banen. Het Akkoord van Wassenaar werd daarmee het symbool van het corporatisme, ofwel 'de buitenparlementaire praktijk van gestructureerde samenwerking en voortdurende onderhandeling 
over vraagstukken van sociaaleconomisch beleid tussen de officiële vertegenwoordigers van de georganiseerde belangen van werkgevers en werknemers...' (1998, p. 94). Hiermee transformeerde de eerdere sick man of Europe zich tot internationaal rolmodel.

Visser en Hemerijck waren niet de eerste sociaal wetenschappers die zich positief uitspraken over de economische prestaties van het corporatisme. Wetenschappelijke bijdragen over de hoogtijdagen van het neocorporatisme hadden al eerder gewezen op de coördinerende rol van overkoepelende belangenorganisaties binnen centrale overlegstructuren (vgl. Lehmbruch en Schmitter, 1982; Schmitter, 1989). Een Nederlands mirakel kwam echter uit op een moment dat velen het corporatisme hadden afgeschreven. Immers, de corporatistische stelsels van weleer hadden sinds de economische crises van de jaren 70 en de ideologische turn van de jaren 80 te maken gehad met decentralisering en informalisering van het corporatistisch beleidsproces (Traxler, 2004). Het succes van de Nederlandse casus toonde echter aan dat het corporatisme ook in de neoliberale jaren go kon aarden. Dat voor corporatistische beleidsprocessen geen centrale overlegstructuren nodig waren, bleek vervolgens ook uit de proliferatie van tripartiete sociale pacten in landen zonder corporatistische traditie (Rhodes, 2001).

Als verklaring voor het Nederlandse succes richtten de auteurs zich op het proces van beleidsleren, ofwel de 'weloverwogen poging om in antwoord op opgedane ervaringen en nieuwe informatie de doeleinden of technieken van beleid bij te stellen' (Hall, in Visser en Hemerijck, 1998 p. 81). In navolging van Hugh Heclo en Peter Hall wezen Visser en Hemerijck op het belang van intellectuele oriëntaties (puzzling) in combinatie met het uitoefenen van macht (powering). In Nederland, zo stelden de auteurs, zijn dergelijke processen uitermate complex, omdat de overheid haar politieke macht deelt met maatschappelijke belangenorganisaties. Dat de sociale partners in staat waren gebleken om het immobiele corporatisme van de jaren 70 ('onderhandelen zonder consensus') nieuw leven in te blazen, was volgens Visser en Hemerijck met name te denken aan de vakbeweging 'als belangrijkste lerende partij'. Deze ging akkoord met loonmatiging zonder de zekerheid te hebben dat het ook zou resulteren in banengroei (ibid., p. 197).

Het verschil tussen het corporatisme van de jaren 90 en dat van zijn voorganger in de jaren 70 , was dat de doelstelling van de partijen verschoof van compromisvorming naar consensus. Hierdoor werd het corporatisme een exponent van de Nederlandse politieke cultuur van het consensualisme, dat tevens uitdrukking vindt in de consociationele democratie (Lijphart en Crepaz, 1991). Consensualisme is een 'normatief geïnstitutionaliseerde manier van conflictoplossing dat een cultuur beschrijft waar met elkaar 
praten en zoeken naar gezamenlijke oplossingen ingebed is in het dagelijkse leven' (Becker, 2001a, p. 421). ${ }^{2}$ Het wordt gekenmerkt door een gezamenlijke set spelregels binnen het beleidsproces, zoals de verwachting van een pragmatische en redelijke houding en een oriëntatie op het algemeen belang (Hendriks, 2011). De dialoog tussen de partijen wordt ondersteund door diverse expert bodies in het stelsel, zoals het Centraal Planbureau, die technocratische en daardoor depolitiserende kennis produceren die de politieke angel uit het beleidsproces halen (ibid.).

Bij Een Nederlands mirakel zijn in de loop der jaren een aantal kritische noten geplaatst. Sommige auteurs vroegen zich af in hoeverre het economische succes in de jaren go daadwerkelijk valt toe te schrijven aan het Akkoord van Wassenaar, of dat externe economische omstandigheden de verklaring bieden. Ook werd de dalende werkloosheid in de jaren $9^{0}$ toegeschreven aan de groei van het aantal deeltijdbanen in plaats van aan loonmatiging (Salverda, 1999; Becker, 20o1b). De mate van consensus binnen het poldermodel werd eveneens betwist. Zo stelde Becker (2001a) dat de vakbonden pas in de jaren 90 daadwerkelijk gingen vasthouden aan loonmatiging en dat hun omarming van het Wassenaarakkoord gezien moet worden als 'ex-post legitimering' van hun aanpassing aan de werkgeversagenda in de jaren 8o. Ook Van Dyk (2006, p. 41) betoogt dat er geen sprake is van een materiële consensus over de beleidsagenda sinds het Akkoord van Wassenaar en dat in plaats daarvan sprake is van een 'symbolische consensus over de consensus, welke een overkoepelende unanimiteit claimt sinds de vroege jaren 80'.

Becker, Van Dyk en anderen plaatsen Een Nederlands mirakel binnen het proces van modelvorming rondom het Nederlands corporatisme. Met deze benadering presenteren zij het Nederlandse poldermodel als constructief fenomeen, waarbij de partijen zowel materiële beleidsvisies als normatieve visies over de aard van de politieke economie in het leven roepen. Modelvorming vindt plaats wanneer een besef van de uitzonderlijke status van het model (Becker noemt dit model consciousness) wordt gecombineerd met een normalisering (taken-for-grantedness) van de dagelijkse praktijken. Het model krijgt discursief gestalte, bijvoorbeeld door de geschiedenis te interpreteren in het licht van het model, door het gebruik van bepaalde symbolen en metaforen, of door het uitleggen van falen als de afwezigheid van het model - retorische constructies die Hajer (2006) de verhaallijnen (story lines) van het discours noemt. Deze verhaallijnen worden gedeeld door coalities van actoren en ondersteund door geïnstitutionaliseerde praktijken. 
Naarmate actoren overtuigd raken van de waarde van het model en van de noodzaak het in stand te houden, zullen ze ook hun politieke gedrag gaan aanpassen aan zijn karakteristieken. Hiermee krijgt het corporatisme een performatief karakter, waarbij de centrale actoren het model in hun dagelijkse praktijk reproduceren.

De constructieve dimensie van het corporatistische overlegmodel is ook van invloed op de processen van puzzling (beleidsleren) en powering (uitoefenen van macht), die centraal stonden binnen Een Nederlands mirakel. Dankzij hun geprivilegieerde toegang tot informatie van maatschappelijke organisaties en beleidsexperts zijn de partijen in staat om het bredere cognitieve kader rondom het beleidsprobleem te scheppen. Zo geven zij richting aan het beleidsproces door het aanleveren van de 'correcte' diagnose van de problematiek en het verwerpen van alternatieve verklaringen. Vaak putten zij uit reeds beschikbare beleidsideeën. Béland (2006) spreekt in dit kader van een logic of availability. Deze beschikbaarheid kan voortkomen uit eerder ingevoerd beleid (policy legacy) of van bijzondere, externe gebeurtenissen die bepaalde thema's onder de aandacht brengen (striking events) (ibid.). Zodoende kunnen de partijen op voorhand al bepaalde beleidsalternatieven als wenselijker presenteren dan andere (Blyth, 2007). Het in stand houden van het model vergt dus niet alleen beleidsleren, maar ook het uitoefenen van macht.

Interne consensus leidt echter niet automatisch tot een legitiem en functioneel stelsel. Traditionele benaderingen van het corporatisme wijzen vaak op het belang van vertegenwoordiging door de sociale partners. De sociale partners geven legitimiteit aan de uitkomsten van het corporatistisch overleg door politieke steun te mobiliseren onder hun leden. Voorwaarde is wel dat het ledenbestand van de sociale partners voldoende representatief is. Vooral de Europese vakbewegingen hebben de afgelopen decennia echter te maken met afnemende ledenaantallen: zo is in Nederland het aantal vakbondsleden sinds eind jaren 70 gedaald van 37 procent van de werknemers naar 18 procent in 2012 (Afonso en Visser, 2015, p. 217). Hierdoor is in veel Europese landen een tweedeling binnen de arbeidsmarkt ontstaan tussen de insiders (overwegend mannelijk, autochtoon en werkzaam in industriële en andere vakbondsdichte sectoren) en outsiders van het corporatisme (vooral vrouwen, migranten en werknemers in de dienstensector) (Häusermann, 2010). Hoewel Nederlandse werkgeversorganisaties nog een relatief hoge organisatiegraad hebben, zijn werkgevers in andere Europese landen steeds minder bereid om deel te nemen aan centraal overleg (Traxler, 2010). Binnen diverse Europese landen staan twee belangrijke institutionele fundamenten van het corporatisme daarom onder druk. 
De inclusiviteit van de vertegenwoordigende partijen is echter niet de enige basis waarop een functioneel en legitiem corporatistisch stelsel gestoeld is. Culpepper (2002, p. 775) wijst in dit kader op het probleemoplossend vermogen van de sociale partners, die als geen andere partij in staat zijn om 'collectieve problemen te identificeren in het licht van de gedeelde ervaringen van hun leden'.Zodoende hebben de sociale partners toegang tot 'superieure informatie', waaronder technische expertise en lokale kennis, die niet direct ter beschikking staat van beleidsmakers. Een belangrijke rol speelt ook de overheid, die de sociale partners kan aansporen tot overleg door te dreigen met unilaterale actie indien geen consensus wordt bereikt. Ook kan de overheid, als enige democratisch verkozen partij, publieke legitimatie aan het beleidsproces geven wanneer de partijen zelf hun representativiteit zien tanen (Ebbinghaus en Hassel, 200o). Met andere woorden, binnen het corporatistisch stelsel kan een gebrek aan input gecompenseerd worden door middel van een effectieve output (Scharpf, 1999).

In dit hoofdstuk betoog ik echter dat een goede input en output niet de enige voorwaarden zijn voor een functioneel en legitiem stelsel. Ook de governance van het stelsel - Vivien Schmidt (2013) noemt dit de throughput - is van belang om consensus over complexe beleidsproblemen te realiseren. Een beleidsproces met een goede throughput is doeltreffend en transparant, open voor consultatie van burgers en/of vertegenwoordigende organisaties, en wordt gevoerd door partijen die hun verantwoordelijkheid nemen voor de uitkomsten (ibid., p. 14). In het vervolg laat ik zien dat juist de drie politieke mechanismen die normaliter bijdragen aan consensusvorming tussen de corporatistische partijen - een gedeelde normatieve visie, een gemeenschappelijke probleemdefinitie en incrementele aanpassing van het beleidsrepertoire - er niet in geslaagd zijn om ook maatschappelijke steun voor het voortbestaan van het huidige pensioenstelsel te mobiliseren. Onderliggende oorzaak is een gebrekkige throughput binnen het beleidsproces zelf, voortkomend uit het proces van modelvorming binnen het Nederlandse pensioenstelsel.

\section{Het pensioenmirakel}

Het idee dat Nederland het beste pensioenstelsel ter wereld heeft, komt niet uit de lucht vallen. Al jarenlang prijkt het Nederlandse stelsel steevast in de hoogste regionen van internationale rankings, zoals de Melbourne Mercer Global Pension Index, en wordt het door internationale experts aangehaald als voorbeeld voor andere landen. Vorig jaar nog kondigde de Britse regering 
aan Dutch-style collectieve pensioenen ook in het Verenigd Koninkrijk te willen invoeren, en in de Verenigde Staten vroeg televisiezender PBS zich hardop af: 'Do the Dutch have the pension problem solved?' (The Guardian, 2014; PBS News Hour, 2013). In binnenlandse kringen wordt de uitzonderlijke positie van het Nederlandse pensioenstelsel al langere tijd onderkend. 'Veel Europese landen zijn jaloers op het Nederlandse pensioenstelsel' en 'Nederland gidsland met een voortreffelijk pensioenstelsel', stelde Het Financieele Dagblad al in de jaren 90 (Het Financieele Dagblad, 1996; Dieten, 1998). Dat het pensioenstelsel een exportproduct is 'waar Nederland mee zou kunnen scoren' werd tevens erkend door lobbyorganisatie Holland Financial Centre, dat in 2007 een rapport uitbracht onder de titel 'Nederland pensioenkampioen: wat staat ons nog te doen?' (Werkgroep Europese Pensioenen, 2007).

De nationale en internationale waardering voor het Nederlandse pensioenstelsel is gebaseerd op drie factoren: de hoge participatiegraad, de grote omvang van het pensioenvermogen en de relatieve generositeit van de pensioenen. Het Nederlandse pensioenstelsel is een driepijlerstelsel dat een basispensioen (AOW) combineert met (quasi-)verplichte arbeidsvoorwaardelijke pensioenen en vrijwillige persoonlijke pensioenproducten. Het overgrote deel van de werknemers in Nederland neemt deel aan een arbeidsvoorwaardelijke pensioenregeling. Volgens het Centraal Bureau voor de Statistiek had in 2010 slechts 8 procent van de werknemers tussen de 25 en 64 jaar geen aanvullende pensioenregeling. Het aantal werkgevers zonder arbeidsvoorwaardelijk pensioen werd door het CBS geschat op 15 procent (De Mooij et al., 2012, p. 18-23). Mede dankzij de hoge participatiegraad heeft Nederland relatief gezien het grootste pensioenvermogen van de OESO-landen: 159,3 procent van het bruto binnenlands product (OECD 2015a). Daarnaast hebben de Nederlandse pensioenen een zeer hoge vervangingsratio in vergelijking met andere landen: een gemiddelde pensioenannuïteit van 90,5 procent van het bruto-inkomen tegenover een OESO-gemiddelde van $5^{2,9}$ procent (OECD, 2015b).

De institutionele kenmerken van het Nederlandse pensioenstelsel zijn nauw verbonden met het poldermodel: het arbeidsvoorwaardenoverleg van de sociale partners dat de pensioenregelingen vastlegt en de vertegenwoordiging van de sociale partners binnen de besturen van pensioenfondsen. Bij voldoende representativiteit kunnen de sociale partners de minister van Sociale Zaken en Werkgelegenheid verzoeken om de pensioenregeling verplicht te stellen voor alle werkgevers en werknemers binnen een bedrijfstak. Deze verplichtstelling is direct gemodelleerd naar de algemeenverbindendverklaring (avv) van de collectieve arbeidsovereenkomsten (cao's). Het uitvoeren van de arbeidsvoorwaardelijke pensioenen is de exclusieve 
taak van de sociale partners; de overheid schept het wettelijke kader en houdt toezicht, maar wordt niet geacht te sterk op dit beleidsterrein te interveniëren. In het verlengde daarvan ligt ook de verwachting dat de vertegenwoordigers van de sociale partners binnen de fondsbesturen niet hun eigen particuliere belangen vooropstellen, zoals vastgelegd in artikel 105 uit de Pensioenwet.

Als uitgangspunt voor het pensioenstelsel worden vaak de principes van 'solidariteit, collectiviteit en betaalbaarheid' genoemd. Solidariteit wordt onder andere bewerkstelligd door de verplichtstelling en de doorsneepremie (een gelijke premie voor alle deelnemers, ongeacht persoonskenmerken). Dankzij de verplichtstelling kan pensioen op bedrijfstakniveau worden georganiseerd, hetgeen concurrentie tussen werkgevers over arbeidsvoorwaarden tegengaat. De doorsneepremie zorgt ervoor dat deelnemers voor wie pensioenkosten actuarieel gezien hoger zijn (ouderen, vrouwen, hoogopgeleiden) voor hetzelfde bedrag pensioen kunnen opbouwen als jongeren, mannen of laagopgeleiden. Collectiviteit maakt risicodeling tussen deelnemers mogelijk, zoals het beleggingsrisico of het langlevenrisico. Tot slot leidt de hoge participatiegraad dankzij de verplichtstelling tot schaalvoordelen binnen pensioenfondsen, die resulteren in lagere administratieve kosten en dus hogere betaalbaarheid.

De arbeidsvoorwaardelijke pensioenen worden gefinancierd via een kapitaaldekkingsstelsel. Dit betekent dat premies van de werkgever en de werknemer worden belegd in financiële markten, en dat de pensioenen worden betaald uit de rendementen op deze beleggingen. Juist in de jaren 9o, toen de aandelenmarkten grote hoogtes bereikten, zijn de Nederlandse pensioenfondsen in toenemende mate in aandelen gaan beleggen. Hierdoor is het pensioenvermogen in korte tijd enorm gestegen: van 375 miljard gulden in 1990 naar 981 miljard in 1999 (PVK, 1990; 1999). Dat de prestaties van de pensioenfondsen daarmee ook gevoelig werden voor fluctuaties op de financiële markten bleek echter tijdens de dot.com-crisis rond de eeuwwisseling, toen beurskoersen kelderden en de gemiddelde dekkingsgraad van de pensioenfondsen daalde van 199 procent in 1999 tot 124 procent ultimo 2002. In de daaropvolgende jaren voerden de sociale partners een aantal belangrijke veranderingen door. Zo werden veel eindloonregelingen vervangen door middelloonregelingen, waardoor de verplichtingen van de pensioenfondsen daalden. Ook werd de indexatie binnen de meeste pensioenregelingen voorwaardelijk, en daarmee afhankelijk gemaakt van de beleggingsresultaten.

Dekkingsgraden daalden wederom tijdens de financiële crisis van 2008 en daaropvolgende jaren, niet zelden onder het minimum van 105 
procent. In hun pogingen de dekkingsgraden te herstellen, schortten veel pensioenfondsen de indexatie van pensioenen op en werd er bij tientallen fondsen ook daadwerkelijk gekort. ${ }^{3}$ Voor werknemers en gepensioneerden kwamen deze handelingen als een onaangename verrassing. Zij zagen hun pensioenaanspraken - 70 procent van het eind- of middelloon - als harde aanspraken en gingen ervan uit dat de pensioenfondsen aan deze verplichtingen zouden voldoen. In 2015 gaf iets meer dan 60 procent van de respondenten uit de DNB Household Survey een positief antwoord op de vraag: 'Heeft u er momenteel vertrouwen in dat het pensioenfonds (de pensioenfondsen) waarbij uw pensioen is ondergebracht in staat zal (zullen) zijn te zijner tijd uw pensioen uit te betalen?' (DNB, 2016, p.13). In 2007 lag dit aantal nog op 87 procent. Daarnaast had minder dan de helft van de respondenten vertrouwen in de pensioensector als geheel (ibid.). Daarmee is het probleem waar politici en beleidsmakers zich mee geconfronteerd zien niet alleen een kwestie van financieel herstel, maar ook van het vertrouwen van de burger in het functioneren van het pensioenstelsel zelf.

\section{Naar een schokbestendig stelsel}

De financiële crisis van 2008 is een goed voorbeeld van een striking event dat de partijen heeft aangezet om hervormingen binnen het pensioenstelsel door te voeren. Toch kan de financiële crisis niet worden aangewend als onderliggende oorzaak voor de pensioenproblematiek. Uit het bovenstaande is gebleken dat de toegenomen kwetsbaarheid van het pensioenstelsel voor volatiliteit op de financiële markten, het gevolg is van politieke keuzes die de partijen al in de jaren 90 hebben genomen. Toch bleek er in het beleidsdebat na 2008 weinig ruimte voor reflectie op het eigen handelen. Met het gebruik van al beschikbare storylines legden de partijen de huidige gebeurtenissen uit in het licht van eerder gesignaleerde maatschappelijke ontwikkelingen. Zodoende ontwikkelden de partijen een visie op de pensioenproblematiek die de oorzaken van de crisis buiten het stelsel situeerde en de partijen

3 Ook in 2016 zijn de dekkingsgraden van veel pensioenfondsen verder gedaald, bij de vier grootste pensioenfondsen zelfs onder het huidige minimum van 9o\%. Daardoor worden verdere kortingen van pensioenaanspraken en -rechten voor 2017 zeer waarschijnlijk. Overigens worden de slechte financiële prestaties anno 2016 niet zozeer geweten aan volatiliteit op de financiële markten, maar aan de lage rentestand (al enige tijd onder de 1 procent). Met name Europese Centrale Bank wordt hierbij als schuldige aangewezen. Toch hebben niet alle Nederlandse pensioenfondsen last van de lage rentestand: fondsen die hun renterisico hebben afgedekt, zijn wel in staat gebleken om hun dekkingsgraden op peil te houden. 
afschermde van de eigen aansprakelijkheid. Het resultaat was een paradoxale set van beleidsvoorstellen die poogden de financiële problemen in het stelsel op te lossen door de afhankelijkheid van beleggingsresultaten nog verder te vergroten.

Op 25 mei 2009 presenteerde minister Donner van Sociale Zaken en Werkgelegenheid (SZW) zijn plannen voor een 'brede aanpak' van het Nederlandse pensioenstelsel aan de Tweede Kamer. 'Binnen de tweede pijler is door kapitaaldekking een omvangrijk vermogen opgebouwd, waardoor het Nederlandse pensioenstelsel beter dan veel andere landen is voorbereid op de aankomende vergrijzing', zo schreef Donner. Toch, stelde Donner, hebben de twee financiële crises van de eenentwintigste eeuw de kwetsbaarheid van het Nederlandse pensioenstelsel aangetoond: 'De hoge mate van kapitaaldekking maakt het pensioenstelsel, en daarmee de inkomensvoorziening van de huidige en toekomstige gepensioneerden, gevoelig voor schokken op de financiële markten' (Kamerstuk 30413, 127). Daarom was politiek ingrijpen volgens de minister gewenst. Deze boodschap - aanpassing van het 'unieke pensioenstelsel van aanvullende pensioenen' met behoud van de 'wezenskenmerken' van het stelsel - werd een jaar later door de minister herhaald in de uiteenzetting van de kabinetsplannen (Kamerstuk 30413 142).

Een tweetal onderzoeken naar de beleggingen van pensioenfondsen (commissie-Frijns), en de toekomst van de tweede pijler (commissie-Goudswaard) werkten de door de minister geopperde diagnose van de pensioenproblematiek verder uit. Volgens beide commissies was het pensioenstelsel kwetsbaar geworden door de vergrijzing van de bevolking en door volatiliteit in de financiële markten (Commissie Beleggingsbeleid en Risicobeheer, 2010; Commissie Toekomstbestendigheid Aanvullende Pensioenen, 2010). Door de toename van het aantal ouderen zullen de pensioenverplichtingen stijgen, zo voorspelden de rapporten, terwijl tekorten niet zonder meer opgelost kunnen worden door premieverhogingen als het aantal werkenden afneemt. Omdat de Nederlandse werknemers en gepensioneerden voor een groot gedeelte afhankelijk zijn van kapitaalgedekte pensioenen, hebben de ontwikkelingen op de financiële markten een directe impact op de hoogte van het pensioen. Niet alleen het beleggen in aandelen, maar ook de lage marktrente lagen volgens beide commissies ten grondslag aan de lage rendementen. Daarmee waren de oorzaken voor de huidige problemen in het pensioenstelsel vooral te wijten aan de veranderende omgeving waarin pensioenfondsen opereren.

De diagnose van de commissies Frijns en Goudswaard sloot nauw aan bij eerdere onderzoeken over de toekomst van het Nederlandse pensioenstelsel. Zo werd de doelstelling van 'een schokbestendig pensioenstelsel' direct 
overgenomen uit het CPB-rapport met dezelfde titel uit 2004, dat verscheen naar aanleiding van de aandelenmarktcrash van 2001. Ook andere publicaties van de Nederlandse expert bodies behandelden dezelfde problematiek (vgl. CPB/DNB/PVK, 2003; Van Ewijk en Van de Ven, 2004; Van Ewijk et al., 2006). Deze onderzoeken richtten zich op een tweetal vraagstukken die nauw met elkaar verbonden zijn: de zekerheid van de pensioenaanspraken en de intergenerationele solidariteit. Door de vergrijzing zullen er minder premiebetalende werknemers zijn, aldus de onderzoekers. Het gevolg is minder ruimte om eventuele financiële tegenvallers op te vangen door middel van premieverhogingen. Pensioenfondsen zullen onderdekking moeten tegengaan door te beleggen in financiële instrumenten met hogere rendementen, zoals aandelen. Deze beleggingen brengen echter ook meer risico met zich mee. Pensioenaanspraken zouden daarom sneller aangepast moeten worden aan de beleggingsresultaten door middel van indexatie of afstempelen (Commissie Beleggingsbeleid en Risicobeheer, 2010; Commissie Toekomstbestendigheid Aanvullende Pensioenen, 2010).

De probleemdefinitie voorgesteld door experts binnen het pensioenstelsel was niet een puur technocratische, maar had ook een politieke lading. Neem bijvoorbeeld de metafoor van 'schokbestendigheid' die door de commissie-Goudswaard als beleidsdoelstelling werd overgenomen uit het eerdere CPB-rapport. Zo geeft de diagnose dat het pensioenstelsel vatbaar is voor externe schokken zoals de vergrijzing en voor turbulentie binnen financiële markten, urgentie aan de nieuwe plannen. Immers, het kenmerkende van beide natuurfenomenen - de aardschok, de turbulente stroming - is dat deze onverwacht kunnen optreden, met schadelijke gevolgen. Daarnaast externaliseert het idee van schokbestendigheid de oorzaken van de problemen in het pensioenstelsel: schokken, maar ook turbulentie, zijn immers niet te wijten aan menselijk handelen. Zowel de vergrijzing als de ontwikkelingen op financiële markten gebeuren in deze diagnose buiten de controle van de partijen om. Dat de sociale partners middels hun zetels in de pensioenfondsbesturen directe invloed over het beleggingsbeleid van de fondsen uitoefenen, wordt gemakshalve buiten beschouwing gelaten.

Ook de politieke verontwaardiging van de burger op de ontwikkelingen in het pensioenstelsel werd onderworpen aan een landschapsmetafoor. In navolging van de AFM concludeerde de commissie-Goudswaard dat het dalende vertrouwen in het pensioenstelsel het gevolg was van een 'gat tussen perceptie en realiteit': de deelnemer verwachtte stelselmatig een hoge pensioenuitkering, maar hield geen rekening met de mogelijkheid tot korten van de pensioenafspraken (AFM, 2010; Commissie Toekomstbestendigheid Aanvullende Pensioenen, 2010, p. 45). Deze 'verwachtingskloof' 
is uitermate problematisch, aldus de commissie, want 'een gebrek aan vertrouwen [zou] er voor kunnen zorgen dat nieuwe deelnemers niet willen toetreden tot het pensioenfonds en (een deel van) de huidige deelnemers zouden willen uitstappen uit het pensioenfonds. Als dat gebeurt, raken we de unieke voordelen van het Nederlandse pensioenstelsel kwijt (een brede risicospreiding en kostenreductie door collectiviteit)' (ibid., p. 46). Om het vertrouwen van de deelnemer te herstellen, pleitten beide commissies voor een transparanter pensioencontract dat de (on)zekerheid van de aanspraken expliciteert.

Specifieke beleidsvoorstellen volgden uit het overleg tussen de sociale partners. In het Pensioenakkoord van 4 juni 2010 en het daaropvolgende uitwerkingsmemorandum van 9 juni 2011 werd de bekende storyline al op de eerste pagina ingezet (Stichting van de Arbeid 2011, p 1):

Het Nederlandse pensioenstelsel behoort volgens deskundigen tot de betere stelsels ter wereld. Wel bestaat de noodzaak het stelsel van tijd tot tijd aan te passen aan gewijzigde omstandigheden. Van belang is daarbij om de belangrijkste kenmerken van dit stelsel overeind te houden. Hiertoe behoort in ieder geval het streven om op decentraal niveau via collectieve afspraken door middel van langetermijnarrangementen op een betaalbare en uitvoerbare wijze solidariteit op pensioenterrein te organiseren tussen de verschillende groepen belanghebbenden.

De documenten bevatten vervolgens de volgende beleidsvoorstellen: ${ }^{4}$

1 Een beperking van het premie-instrument om kostenstijgingen binnen de tweede pijler te voorkomen. De partijen onderschrijven de conclusie van de commissie-Goudswaard dat de pensioenpremie een maximale hoogte heeft bereikt (17,9 procent van het brutoloon voor de AOW en gemiddeld 20 procent voor de aanvullende pensioenen).

2 Een koppeling van de AOW-leeftijd aan de leeftijdsverwachting, waardoor de AOW-leeftijd in 2020 verhoogd wordt naar 66 jaar en in 2025 naar 67 jaar. Ook de pensioenleeftijd voor de arbeidsvoorwaardelijke pensioenen wordt aangepast aan de stijgende levensverwachting.

3 De introductie van een flexibel pensioencontract: er komt een keuze tussen een nominaal contract met minder kans op korten maar ook minder aanpassingen aan inflatie, en een contract waarbij een reële

4 Het Pensioenakkoord bevat ook afspraken over de arbeidsparticipatie van ouderen, maar dit thema wordt in dit hoofdstuk buiten beschouwing gelaten. 
toezegging zou worden gedaan (geen zekerheid, maar grotere kans op indexatie).

4 Transparantie van pensioencontracten: het moet duidelijk worden hoe het beleggingsbeleid van een pensioenfonds past bij het risicoprofiel van de deelnemers. Zodoende hopen de sociale partners de verwachtingskloof van de deelnemers te dichten.

Met het onderscheid tussen de twee pensioencontracten werd de afhankelijkheid van financiële markten niet alleen expliciet erkend, maar ook versterkt. Bij een nominaal contract zou een pensioenfonds behoudender moeten beleggen om de uitkomsten zekerder te stellen, terwijl bij het reële contract een assertiever beleggingsbeleid nodig zou zijn om indexatie te kunnen toekennen. Uitgangspunt voor de partijen was dat beleggingsrisico een vast onderdeel is van het Nederlandse kapitaalgedekte stelsel. Niet de beleggingspraktijken van de pensioenfondsen moesten daarom veranderen, maar de 'verkeerde verwachtingen' van de deelnemer over de zekerheid van zijn pensioen (Van Ewijk en Teulings, 2011, p. 9). Risicovol beleggen was immers noodzakelijk voor een goed pensioen, aldus de partijen. 'We gaan er hard aan werken die boodschap duidelijker uit te leggen', beloofde de voorzitter van de Pensioenfederatie. 'Want als we niet meer beleggen, dan wacht ons allemaal een arme oude dag' (Pensioenfederatie, 2010). Daarmee werd het probleem waar het beleid zich op richtte, de financiële volatiliteit, tevens onderdeel van de oplossing.

De reacties van beleidsmakers, sociale partners en experts op de performancecrisis binnen het pensioenstelsel laten zien dat de totstandbrenging van een consensus verder gaat dan afstemming over het te voeren beleid. Een gedeelde overtuiging van de normatieve basis van het pensioenstelsel (het belang van solidariteit, collectiviteit, betaalbaarheid) en een gezamenlijke probleemdefinitie faciliteerden het proces van consensusvorming. Tegelijkertijd werd de afstemming tussen de partijen gekenmerkt door een aantal elementen, geassocieerd met het proces van modelvorming, zoals de herhaaldelijke verwijzingen naar de uitzonderlijke status van het pensioenstelsel en het hanteren van een vaste set metaforen om de problemen in het pensioenstelsel te duiden. De partijen baseerden zich op reeds beschikbare analyses van de kwetsbaarheid van het Nederlandse pensioenstelsel. Deze analyses boden niet alleen aanknopingspunten voor mogelijke oplossingen, maar legitimeerden ook de eerdere politieke keuzes die ten grondslag lagen aan de financialisering van het pensioenstelsel. Hierdoor werd het voor de partijen mogelijk om een beleidstraject te blijven volgen dat reeds voor de financiële crisis was ingezet en kreeg het een haast 'onvermijdelijk' karakter (Van Ewijk en Teulings, 2011). 


\section{Grepen uit de kas}

Dat de voorstellen om het pensioenstelsel schokbestendig te maken verre van onvermijdelijk waren, bleek uit de vele kritische reacties op het Pensioenakkoord. In de kritieken op het Pensioenakkoord resoneerde niet alleen ontevredenheid over het beleidsinstrumentarium dat door de partijen was voorgesteld. Met name de probleemdefinitie van de commissies Frijns en Goudswaard - de vergrijzing en financiële schokken nopen tot schokbestendigheid - werd van verschillende kanten onderuitgehaald. In plaats daarvan ontwikkelden critici - een gemêleerd gezelschap van politici, experts en burgers - alternatieve verhaallijnen, waarbij de oorzaken voor de problemen binnen het stelsel zelf werden gezocht: graaiende werkgevers, speculatieve pensioenfondsen en ondemocratische vakbonden. Grote gemene deler tussen deze verhaallijnen: een duidelijke identificatie van handelende actoren die schuldig worden geacht voor het verlagen van de pensioenen. Door de nadruk te leggen op de aansprakelijkheid van verschillende groepen actoren binnen het pensioenstelsel richtten de critici zich dus met name op de throughput, in plaats van de input of output van het pensioenstelsel.

Een eerste groep critici trok de probleemdefinitie van de partijen direct in twijfel door de huidige tekorten van de pensioenfondsen niet aan financiële schokken of de vergrijzing te wijten, maar aan de zogenaamde 'grepen uit de kas' (vgl. Van Baars, 2012): de praktijken van de werkgevers in de jaren 80 en 90 om vermogensoverschotten uit de pensioenfondsen terug te laten vloeien in het bedrijf of om tijdelijk de premiebetaling op te schorten. Net als de probleemdefinitie van de commissie-Goudswaard dateerde deze verhaallijn van voor de financiële crisis. Zo weet de Pensioenen Verzekeringskamer (PVK) al in 2002 de verslechterde prestaties van de fondsen na de dot.com-crisis niet zozeer aan de beleggingsresultaten, maar aan het heffen van te lage premies en het verlenen van premieholidays of indexatie zonder gezonde financiële basis (PVK, 2002). Omdat er anno 2011 nog steeds veel onduidelijkheid was over het concrete bedrag dat destijds aan de pensioenfondsen was onttrokken (de PVK noemde in 2002 een bedrag van zo'n $€ 5$ miljard), pleitten diverse commentatoren voor additioneel onderzoek en het compenseren van de huidige tekorten middels bijstortingen door de werkgevers.

Een tweede verhaallijn plaatste het Pensioenakkoord in de context van een strijd tussen de generaties, niet zelden daartoe aangewakkerd door de nieuwsmedia. 'Jongere dankt luxe klimaat aan ons', 'De opstand van jong tegen oud' en 'Kan veertiger straks ook nog golfbaan op?' klonken de krantenkoppen (Algemeen Dagblad, 2011; König, 2011; Staal, 2011). De media 
gaven ruim baan aan jongeren, die babyboomers ervan beschuldigden hen met een grote financiële last opgezadeld te hebben. Ouderen klaagden ondertussen dat de jongeren zelf te weinig solidariteit toonden met oudere werknemers die jarenlang premie hadden betaald en nu hun pensioenen gekort zien worden. Terwijl ouderenorganisaties zich verzetten tegen de flexibilisering van de pensioenaanspraken, pleitten politieke jongerenorganisaties voor een fundamentele herziening van het pensioenstelsel waarbij collectiviteit zou worden ingeruild voor individuele pensioenrekeningen. Anders, zo stelden de jongeren, 'stort het beste pensioenstelsel ter wereld als een kaartenhuis in elkaar' (Boelaars et al., 2012). Tevens betichtten de jongerenpartijen de partijen binnen het polderoverleg ervan de belangen van de jongeren onvoldoende in acht te nemen. Met name de vergrijzende vakbonden kregen het te verduren. De 'polderdictatuur dupeert jongeren', stelde een commentator. Volgens een ander: 'Intergenerationele solidariteit betekent in dit plan dat de vakbondsleiders de pensioenpot mogen leegroven' (Boelaars en Koning, 2011; Spits, 2011). Daarmee positioneerden de jongerenorganisaties zich expliciet als outsiders binnen het pensioendebat.

Dat de onenigheid over het Pensioenakkoord zich echter niet in simpele insider-outsider scheidslijnen liet vatten, bleek uit de oppositie tegen het akkoord vanuit de vakbeweging zelf. FNV Bondgenoten uitte haar zorgen over het ontbreken van een verplichting voor werkgevers om in geval van tekorten bijstortingen te doen. Zonder deze toezeggingen, vreesde de bond, zal het akkoord resulteren in 'casinopensioenen', waarmee de pensioenfondsen onnodig speculeren op financiële markten. Immers, zo stelde voorzitter Van der Kolk, de druk om slechte beleggingsresultaten te verhullen wordt hoger 'omdat bedrijven hun zakken gesloten houden en niet willen bijbetalen' (De Telegraaf, 2011). Ook diverse experts, waaronder DNB-directeur Lex Hoogduin, waren bang dat het Pensioenakkoord pensioenfondsen een prikkel zou geven om riskanter te gaan beleggen, omdat pensioenfondsen hun financiële positie mochten gaan bepalen op basis van het verwacht rendement. Immers, hoe hoger het risico, hoe hoger het rendement. Bij een hoger rendement is ook eerder indexatie mogelijk. Echter, als fondsen hun eigen financiële positie te optimistisch inschatten, neemt de kans toe dat op termijn te weinig vermogen in kas zal zijn om de pensioenen van de jongere generaties te betalen (Bovenberg et al., 2011; Hinrichs, 2011)

De reactie van de partijen op de kritiek op het Pensioenakkoord was tweeledig. Allereerst werden alternatieve verhaallijnen resoluut verworpen. Zo legde het kabinet de maatschappelijke roep om meer inzicht te creëren over de 'grepen in de kas' naast zich neer, zelfs nadat bekend werd dat de overheid zelf in de jaren 80 zo'n 30 miljard gulden uit het ABP heeft gehaald. 
Wel gaf staatssecretaris Klijnsma de opdracht om een pilotstudie te doen naar de terugstortingen. Uit de pilotstudie, uitgevoerd door PriceWaterhouseCoopers, bleek dat bij vijf pensioenfondsen in de periode 1985-2011 meer dan $€ 1$ miljard aan terugstortingen werd gedaan. Veel meer duidelijkheid kon het onderzoek echter niet geven, omdat veel pensioenfondsen onvoldoende informatie over deze terugstortingen hadden bewaard. Staatssecretaris Klijnsma besloot echter geen nader onderzoek in te stellen, met als motivatie dat de kosten van deze studie te hoog zouden zijn (geschat op $€ 10$ miljoen). Diverse moties van Tweede Kamerlid Pieter Omtzigt om de staatssecretaris alsnog te dwingen een dergelijk onderzoek uit te voeren, werden verworpen door de coalitiepartijen in de Tweede Kamer.

Tegelijkertijd bleven de partijen vasthouden aan hun verhaal. In een gezamenlijke verklaring ('Waarheid over ons akkoord') stelden werkgevers en vakbonden dat het 'een sprookje' was om te geloven dat de huidige problemen in het pensioenstelsel opgelost konden worden door de pensioenpremie verder te verhogen. Deelnemers riskeerden altijd al pensioenkortingen als dekkingsgraden daalden, waarschuwden de sociale partners, alleen waren zij zich daar niet voldoende van bewust geweest. Het nieuwe pensioencontract zou daarom deze risico's benoemen en uitleggen aan de deelnemers. Het akkoord moest dan ook niet gezien worden als een bezuinigingsmaatregel op de aanvullende pensioenen, maar als een realistischer kijk op bestaande financiële risico's (Jongerius et al. 2011). De pogingen van de partijen om het Pensioenakkoord te redden waren echter tevergeefs. Nadat de leden van FNV Bondgenoten en Abvakabo - samen partij bij go procent van de cao's - het Pensioenakkoord verwerpen, bleek de status ervan onhoudbaar. De verdeeldheid over het Pensioenakkoord leidde tot interne onenigheid binnen de vakbeweging en tot de start van een intern vernieuwingsproces, dat eind 2014 resulteerde in een fusie van de grootste bonden, waaronder Bondgenoten, Abvakabo en Bouw. Het demissionaire kabinet-Rutte I vulde het tijdelijke machtsvacuüm door een akkoord te sluiten met het CDA en drie oppositiepartijen (D66, GroenLinks, ChristenUnie) en zodoende zijn eigen voorstellen, waaronder een versnelde verhoging van de AOW-leeftijd, door de Eerste en Tweede Kamer te loodsen.

Bezien vanuit de wetenschappelijke literatuur lijkt de opkomst en ondergang van het Pensioenakkoord een aantal voorspelbare ingrediënten te bevatten. De maatschappelijke ontwikkelingen die vaak worden aangewezen als onderliggende oorzaken van verzwakking van het corporatisme - de opkomst van nieuwe belangengroepen, de afnemende representativiteit van de sociale partners - lijken op het eerste gezicht ook in het pensioendebat een belangrijke rol te spelen. Zo is de tegenstelling tussen jong 
en oud een vaak gehoorde verhaallijn binnen het pensioendebat en laten nieuwe belangengroepen rondom deze tegenstelling (zoals de politieke jongerenpartijen, maar ook een politieke partij als $5_{5}$ PLUS) in toenemende mate van zich horen. Toch is de vraag of er hier echt sprake is van een nieuwe politieke scheidslijn. Immers, deze groepen komen veelal voort uit bestaande organisaties binnen het corporatistische bestel, zoals de vakbonden en de politieke partijen. Dat de overlegeconomie vervolgens prima in staat is gebleken om nieuwe belangen te coöpteren en te integreren blijkt onder andere uit de gezamenlijke verklaring van sociale partners, Pensioenfederatie en diverse jongeren- en ouderenorganisaties over het nieuwe pensioencontract (StvdA, 2013).

Waarom is het de overheid en sociale partners dan niet gelukt om brede maatschappelijke steun voor de plannen af te dwingen? Uit het bovenstaande is gebleken dat de kritiek op het Pensioenakkoord slechts ten dele gericht was op de effectiviteit van het voorgestelde beleid (de output) of de representativiteit van de sociale partners (de input). Grote gemene deler tussen de alternatieve verhaallijnen was de onenigheid over de door de partijen ontwikkelde probleemdefinitie, waarmee de beleidsvoorstellen van kabinet en sociale partners werden gelegitimeerd. Niet alleen betwijfelden diverse critici de aangevoerde oorzaken van de pensioenproblematiek (demografische en financiële schokken), ook wezen zij op de aansprakelijkheid van de overheid en de sociale partners in het veroorzaken van de performancecrisis binnen het pensioenstelsel. Zo openbaarde zich een tweede tegenstrijdigheid in het proces van consensusvorming: hoewel de partijen hoog inzetten op de uitlegbaarheid van hun plannen om zodoende de 'verwachtingskloof' van de burger te overbruggen, waren zij niet bereid om het eigen handelen aan de burger uit te leggen. Daarmee lijkt de kritiek op het Pensioenakkoord niet zozeer gegrond in gebrekkige input of output, maar op een slechte throughput binnen het pensioenstelsel.

\section{Legitimiteit en functionaliteit in de pensioenpolder}

Maatschappelijke onvrede over publiek beleid hoeft niet automatisch te leiden tot veranderingen in datzelfde beleid. Toch hebben alternatieve visies op de Nederlandse pensioenproblematiek wel degelijk hun weerslag gehad op de hervormingsplannen van het kabinet en de sociale partners. Politieke wetenschappers wijzen in deze context op het belang van zogeheten feedbackeffecten (vgl. Pierson, 1993): een verzameling van maatschappelijke, economische en politieke effecten die bestaand beleid kunnen versterken 
of juist ondermijnen. Een belangrijk zelfversterkend feedback-effect is de aanwezigheid van grote groepen in de maatschappij met een gevestigd belang in de status quo (Weaver, 2015). Deze groepen vormen een politiek obstakel voor hervormingen, waardoor beleidsveranderingen niet of slechts incrementeel plaats zullen vinden. Het feedback-effect wordt echter zelfondermijnend wanneer grote groepen in de maatschappij lijken te verliezen bij bestaand beleid. Met name wanneer tegenstanders in staat zijn om deze groepen te mobiliseren, kunnen sociaal-politieke feedback-effecten bijdragen aan aanzienlijke veranderingen in beleid (ibid.).

Ook bij de huidige casus van het Nederlandse pensioenstelsel zijn verschillende zelfversterkende en zelfondermijnende feedback-effecten aanwezig. De golf aan pensioenkortingen na de financiële crisis heeft niet alleen de materiële belangen van zowel jongere als oudere werknemers aangetast, maar ook hun gevoel van vertrouwen in een adequate oudedagsvoorziening. Deze onvrede is vervolgens effectief gemobiliseerd door voorstanders van individualisering van het pensioenstelsel. Daaronder valt onder andere de politieke partij VVD, al sinds midden jaren go een voorstander van het afschaffen van de verplichtstelling, maar ook de verzekeringsindustrie, die winst ruikt bij het wegvallen van de 'oneerlijke concurrentie' van de pensioenfondsen. Onderzoek wijst uit dat de roep om meer individuele keuzevrijheid resoneert onder aanzienlijke delen van de bevolking (Koenen, 2014), hoewel respondenten ook vaak aangeven hun pensioen nog steeds te willen uitbesteden aan pensioenfondsen. Dat is niet zo verrassend: juist in een pensioenstelsel met verplichte deelname en weinig directe invloed over de pensioenregeling is individuele keuze immers al snel een aantrekkelijk alternatief voor de bestaande situatie.

Tegelijkertijd hebben het kabinet en sociale partners getracht hun critici wind uit de zeilen te nemen door hen op te nemen in bestaande overlegstructuren. Zo heeft het kabinet geprobeerd om de maatschappelijke onvrede te kanaliseren door burgers meer inspraak te geven in het pensioendebat. Uniek voor Nederland was bijvoorbeeld de Nationale Pensioendialoog, die in het najaar van 2014 door staatssecretaris Klijnsma werd georganiseerd. Onderdeel van deze dialoog waren onder andere een adviesvraag aan de SER, een online consultatie, en openbare bijeenkomsten door het hele land. Ook de sociale partners en de pensioenfondsen hebben meer ruimte geboden aan nieuwe geluiden. De jongerentakken van vakcentrales FNV en CNV hebben bijvoorbeeld het Pensioenlab opgericht, een denktank voor jongeren op het gebied van pensioen. Binnen pensioenfondsen hebben individuele deelnemers meer zeggenschap gekregen, bijvoorbeeld door de directe verkiezingen van verantwoordingsorganen. Daarmee hebben kabinet en 
sociale partners de kritiek op hun beleid effectief gecoöpteerd zonder de institutionele kenmerken van het model aanzienlijk te veranderen.

De term layering wordt vaak gebruikt om een gelaagd institutioneel regime te beschrijven, waarbij nieuwe elementen als het ware bovenop een stabiel institutioneel kader worden geplaatst (Thelen, 2004). Ook het samenspel van versterkende en ondermijnende feedback-effecten binnen het pensioendebat heeft geleid tot een zekere gelaagdheid in de beleidsagenda. In de hoofdlijnennotitie van zomer 2015 concludeerde de staatssecretaris dat pensioen beter moet aansluiten bij de individuele behoeften van deelnemers (Kamerstuk 32043, 241). Ook de doorsneepremie moet volgens de staatssecretaris aangepast worden en vervangen worden door een systeem van degressieve pensioenopbouw. Deze voorstellen, in 2010 nog niet politiek opportuun beschouwd door toenmalig minister Kamp, worden inmiddels actief ondersteund door centrale actoren in de pensioenpolder (Kamerstuk 32043, 254; CPB 2014). Daarnaast pleitte de staatssecretaris voor een 'transparante contractvorm', een combinatie tussen de middelloonregeling en de beschikbare premieregeling, en meer individuele keuzevrijheid op het gebied van het beleggingsbeleid, de hoogte van de premie-inleg en de vorm van de uitkering (Kamerstuk 32043, 241). ${ }^{5}$

De plannen van staatssecretaris Klijnsma komen slechts ten dele tegemoet aan de eerdergenoemde kritiekpunten. Zo is de vakbeweging er niet in geslaagd om de werkgevers te verleiden tot het doen van bijstortingen om de verliezen van 2008 te compenseren. In plaats daarvan ontdoen werkgevers zich juist steeds vaker van hun bijstortverplichting en laten zij maximale pensioenpremies opnemen in pensioenovereenkomsten. Hierdoor verschuift het risico in toenemende mate naar de deelnemers. Ook de wens van bepaalde jongerengroepen om deelnemers hun eigen pensioenuitvoerder te laten kiezen, vindt geen brede politieke steun. Immers, individuele keuzevrijheid zou het einde betekenen van de verplichtstelling, waardoor de Nederlandse pensioenfondsen hun status aparte onder het Europese mededingingsrecht zullen verliezen. Ook de vertegenwoordiging van de sociale partners binnen de pensioenfondsbesturen verliest daarmee haar rationale. Andere oplossingen voor de pensioenproblematiek, zoals toelaten van meer werknemers tot de Nederlandse

5 Geen onderdeel van het ftk is het onderscheid tussen het nominale en het reële pensioencontract, dat in 2013 door staatssecretaris Jette Klijnsma van Sociale Zaken en Werkgelegenheid geschrapt is, nadat er onder maatschappelijke partijen (sociale partners, ouderen- en jongerenorganisaties, Pensioenfederatie) onvoldoende steun bleek voor de twee varianten (Kamerstuk $32043,172)$. 
arbeidsmarkt door middel van migratie, zijn niet eens onderdeel van het politieke debat. In plaats daarvan is de AOW-leeftijd verhoogd en zijn de fiscaal maximale opbouwpercentages voor de aanvullende pensioenen neerwaarts aangepast.

Ook komen de nieuwe plannen nauwelijks tegemoet aan roep om meer inzicht te verschaffen in het beleggingsbeleid van de pensioenfondsen. Wel is per 1 januari 2015 een nieuw financieel toetsingskader (ftk) voor pensioenfondsen in werking getreden. Onder het nieuwe ftk moeten pensioenfondsen hogere buffers aanhouden, wordt indexatie aan strengere eisen gebonden en krijgen de fondsen langer de tijd om onderdekking te herstellen. In plaats van tegemoet te komen aan de wens van veel burgers om de pensioenen vooral zekerder te maken, worden de nieuwe financiële regels juist aangegrepen om pensioenfondsen meer vrijheid te geven risicovol te beleggen. Zo motiveerde Klijnsma de voorkeur voor een degressieve pensioenopbouw, omdat dan 'relatief veel risico kan worden genomen' (ibid.). Vertrouwen in het pensioenstelsel moet met name hersteld worden door de risico's beter uit te leggen aan de deelnemer (zie ook AFM, 2015). Ook deze positie is vanuit politiek opzicht begrijpelijk: de partijen baseren zich op het idee dat een hoog beleggingsrisico zich vertaalt in hoge rendementen. Hoge rendementen betekenen lagere pensioenpremies, hetgeen met name voor werkgevers een groot kostenvoordeel oplevert. Dat een hoog beleggingsrisico ook een grotere kans op verlies met zich brengt, wordt door de partijen gemakshalve over het hoofd gezien.

Hoewel de partijen op het eerste gezicht een belangrijke knieval lijken te hebben gemaakt richting de voorstanders van liberalisering en individualisering van het pensioenstelsel, vergen de voorgestelde plannen dus geen grote aanpassing van het Nederlandse pensioenstelsel. Belangrijke onderdelen van het pensioenmodel blijven anno 2016 nog gewoon intact: de partijen laten zich nog steeds leiden door de uitzonderlijke status van het pensioenstelsel, en ook de kritiek op het Pensioenakkoord heeft niet geleid tot het gebruik van andere metaforen binnen de dominante verhaallijnen van de partijen. Nog standvastiger is de wijze waarop de partijen gecommitteerd blijven aan een tweetal genormaliseerde praktijken binnen het stelsel. Zo hebben de sociale partners geen enkele invloed af hoeven staan aan andere actoren. Ook bij de introductie van meer maatwerk binnen pensioenregelingen zullen pensioenfondsen nog steeds de belangrijkste pensioenuitvoerders blijven, bestuurd door de sociale partners. Ook de hoge mate van financialisering wordt nog steeds als vanzelfsprekend onderdeel van het stelsel beschouwd. In de ogen van kabinet en sociale partners is financiële volatiliteit niet een beleidsprobleem dat opgelost dient te worden, 
maar een gegeven waar actoren binnen het pensioenstelsel zich aan moeten aanpassen, inclusief de deelnemers.

Opvallend aan bovenstaande casus is hoe weinig de partijen gebruik hebben gemaakt van puzzling en powering, de twee mechanismen die eerder door Visser en Hemerijck (1998) als belangrijke verklaring voor het Nederlands mirakel zijn aangewezen. Zowel experts als partijen bouwden voort op reeds bestaande diagnoses, die het eerder ingezette beleidstraject niet in twijfel trokken. Alternatieve analyses, bijvoorbeeld over de 'grepen uit de kas' van de jaren 80 en 9o, werden niet toegelaten tot het debat. In plaats daarvan doen overheid en sociale partners verwoede pogingen om het Nederlandse pensioenmodel in stand te houden. Een gedeelde normatieve visie, het ontwikkelen van een gemeenschappelijke probleemdefinitie en incrementele aanpassing van het beleidsrepertoire door overheid en sociale partners dragen in deze context niet alleen bij aan het proces van consensusvorming tussen de partijen, maar isoleert hen tegelijkertijd van maatschappelijke tendensen die de instituties van het pensioenmodel kunnen ondermijnen. Niet het democratisch gehalte van het stelsel of de effectiviteit van het beleid staat momenteel voorop, maar de 'uitlegbaarheid' van de voorgestelde maatregelen om zodoende de verwachtingskloof van de burger te dichten. Door zich op te stellen als deskundigen die beter weten dan de burger wat goed voor hem is, gaan de partijen voorbij aan hun rol als belangenvertegenwoordiger.

\section{Conclusie}

Acht jaar na de financiële crisis hebben de Nederlandse pensioenfondsen nog steeds te kampen met lage dekkingsgraden, uitstel van indexatie en het korten van pensioenrechten en -aanspraken. Ook het vertrouwen van de burger in het pensioenstelsel is verre van hersteld. Desalniettemin kondigde de staatssecretaris in april 2016 aan een grondige hervorming van het pensioenstelsel over te laten aan het volgende kabinet. Het is dan ook niet verwonderlijk dat de toekomst van het Nederlandse pensioenstelsel nog steeds ter discussie staat. Het pensioendebat heeft een tweetal opmerkelijke kenmerken. De 'heilige huisjes' van het stelsel, met name de verplichtstelling en de doorsneepremie, worden in toenemende mate bekritiseerd door actoren binnen en buiten het stelsel zelf. De veranderingen die inmiddels zijn doorgevoerd, zoals het verhogen van de AOW-leeftijd en het nieuwe financiële toetsingskader, lijken weinig zoden aan de dijk te zetten. Waarom is het de overheid en sociale partners tot op heden 
niet gelukt om het pensioenstelsel zijn miraculeuze kenmerken terug te geven?

In dit hoofdstuk is de nadruk gelegd op de politieke mechanismen van consensusvorming, die de institutionele praktijken binnen het pensioenstelsel, zoals het overleg van de sociale partners, ondersteunen. Deze consensus bestaat onder andere uit een gedeelde overtuiging van de wezenskenmerken van het stelsel (solidariteit, collectiviteit, betaalbaarheid), een gezamenlijke visie op de pensioenproblematiek (vergrijzing, financiële volatiliteit) en het gebruik van gemeenschappelijke storylines en symbolen (schokbestendigheid, verwachtingskloof). Elk van deze elementen heeft bijgedragen aan de vormgeving van nieuw pensioenbeleid (o.a. de verhoging van de AOW-leeftijd en de introductie van een nieuw pensioencontract) en legitimering daarvan richting de samenleving. Daarbij is voortgeborduurd op een beleidstraject dat al rond de eeuw wisseling is ingezet, maar door de financiële crisis aan nieuw momentum heeft gewonnen.

De 'onzekere zekerheid', in de woorden van de commissie-Frijns, is inmiddels verworden tot een 'zekere onzekerheid' voor de gemiddelde deelnemer: de financiële crisis heeft niet geleid tot een beperking van de invloed van financiële markten over de pensioenen. In plaats daarvan hebben het kabinet en de sociale partners ingezet op de uitlegbaarheid van de risico's naar de burger toe. Daarmee laten deze partijen het na om hun eigen handelen voorafgaand aan en tijdens de financiële crisis aan nadere inspectie te onderwerpen. Het is juist dit gebrek aan zelfreflectie waar de alternatieve verhaallijnen (de grepen in de kas, de self-serving sociale partners) binnen het pensioendebat zich op richten. Er lijkt in een toenemende mate ruimte te zijn gecreëerd voor nieuwe ideeën. Met name bij de roep om keuzevrijheid komen de behoeften aan meer eigen controle over het eigen pensioen en een eerlijke verdeling tussen jong en oud samen.

De recente ontwikkelingen in het Nederlandse pensioenstelsel tonen aan dat de coördinatie van sociaaleconomische vraagstukken niet alleen plaatsvindt door middel van overleg tussen overheid en koepelorganisaties - in dit geval bleken de vakbonden zelfs te zeer intern verdeeld om consensus te bereiken over het Pensioenakkoord - maar ook via een gedeelde normatieve en discursieve oriëntatie op de beleidsagenda. De twee mechanismen die centraal stonden in het boek van Visser en Hemerijck, puzzling en powering, speelden een minder belangrijke rol binnen het corporatistische overleg. In plaats daarvan waren de centrale actoren binnen het stelsel veel meer extern gericht op het communiceren van een eenduidige boodschap richting de deelnemer, en het demobiliseren van de aanwezige critici (o.a. door kritiekpunten van de politieke agenda te houden en critici in het overleg 
op te nemen). Dat deze strategie er uiteindelijk niet in geslaagd is om het maatschappelijke vertrouwen van de Nederlandse pensioenkampioen te herstellen, wijst erop dat democratische vertegenwoordiging en effectief beleid niet voldoende zijn voor een functioneel en legitiem stelsel. Met name in de huidige tijd van dalende ledenaantallen en complexe beleidsproblemen spelen zogenaamde throughput factoren een belangrijke rol bij het voortbestaan van corporatistische overlegstructuren, zoals het Nederlandse poldermodel. 


\title{
$7 \quad$ Nieuw Nederlands polderen
}

\author{
Van brede sociale akkoorden naar 'ad hoc' \\ hervormingscoalities ${ }^{1}$
}

Anton Hemerijck en Marc van der Meer

\section{Terug naar de polder, maar anders}

Op 11 april 2013 sloten werkgevers, werknemers en de overheid in Den Haag het zogenoemde Mondriaan-akkoord. De nieuwe overeenkomst werd afgesloten drie jaar nadat de laatste poging tot een sociaal akkoord, het pensioenakkoord van 2010, jammerlijk was mislukt en de economie een zware crisis had doorgemaakt. Bij de lancering werd het nieuwe akkoord door minister-president Mark Rutte gedoopt tot een 'nieuw Akkoord van Wassenaar', naar analogie van het fameuze Akkoord van Wassenaar dat ruim 30 jaar eerder tot stand kwam. Indertijd was het doel via een strategie van loonmatiging de reële wisselkoers van de gulden te verlagen en de concurrentiepositie van de Nederlandse producten en bedrijven te verbeteren en daarmee nieuwe banen te scheppen. Deze strategie, breed ondersteund door regering en de sociale partners, was, samen met belangwekkende hervormingen in sociale zekerheid en arbeidsmarktbeleid, in de jaren 90 zo succesvol dat later op nationale en internationale fora werd gesproken van A Dutch Miracle (Visser en Hemerijck, 1997; Hemerijck en Visser, 2001). Of het meest recente sociaal akkoord en de reeks aan domeinafspraken over hervormingen in de zorg, de woningmarkt, de pensioenen, het onderwijs, de techniek en aangaande klimaat en energie, die het kabinet-Rutte II sinds zijn aantreden op 5 november 2012 met maatschappelijke organisaties en de zogeheten 'constructieve' oppositiepartijen (D66, ChristenUnie en SGP) in Tweede en Eerste Kamer overeenkwam, een nieuw leven voor de Nederlandse polder inluidt, is de centrale vraag van deze bijdrage.

Als onlosmakelijk onderdeel van de Europese economie en de Eurozone is de Nederlandse economie sinds het uitbreken van de internationale

1 Met dank aan onze interviewpartners Laurens Harteveld (AWVN), Leo Hartveld (FNV), Rob Mulder (VEH) en Patrick Jeurissen en Aloys Kersten (VWS), alsmede aan de VU honoursstudenten Stijn Bleichrodt, Rogier Habets, Maura van de Velde en Shahenshah Yaqut voor hun papers over deze problematiek, en aan Midas Dutij voor zijn onderzoekassistentie. Correspondentie: a.c.hemerijck@vu.nl; marc.vandermeer@uvt.nl. 
kredietcrisis in zwaar weer komen te verkeren. Noodzakelijke reddingsoperaties voor banken om de eerste klappen op te vangen, hebben een zware wissel op de openbare financiën getrokken. Gedwongen door de kettingreactie van crisis-naschokken hebben ook de Europese beleidsmakers niet stil gezeten. Alhoewel kritiek bestaat op het restrictieve karakter van de maatregelen, die keer op keer leidden tot het neerwaarts bijstellen van groeiprognoses, zijn reddingfondsen en lagere rentes voor Griekenland, Ierland en Portugal, en fiscale discipline voor de gehele Eurozone effectief aangewend om de euro drijvend te houden. Met zijn omvangrijke financiële sector liepen in Nederland het overheidstekort en de staatschuld in 2009 en 2010 fors op tot een EMU-tekort van 5 procent. Nadat in 2010 de banken waren gered, moest Den Haag vervolgens vol aan de bak om te voldoen aan de nieuwe budgettaire spelregels van de Europese Unie (EU), afgesproken in 2011 in het kader van het zogeheten Europese Semester. Sindsdien heeft de EU nationale begrotingen onder strenger toezicht geplaatst, waarmee de ruimte voor fiscale vraagstimulering werd ingesnoerd. Maar ook de private sector bood geen soelaas. De hoge hypotheekschuld onder particulieren, direct verbonden met het grote belang van de financiële sector, drukte de economische groei in Nederland in de nasleep van de internationale financiële crisis (zie Engelen in deze bundel), omdat de banken hun kredietverlening beperkten.

Tegen de achtergrond van de vele economische tegenvallers die de Nederlandse economie kreeg te verduren, is onderkenning van de hervormingsprestaties van het tweede kabinet onder leiding van liberaal Mark Rutte, na een valse start over de inkomensafhankelijke zorgpremie, op zijn plaats. In tegenstelling tot het vechtkabinet van Balkenende IV en het door de PVV gedoogde kortstondige experiment van het eerste kabinetRutte, die de noodzakelijke eensgezindheid ontbeerden om structurele hervormingen ten uitvoer te leggen, kan Rutte II bogen op een reeks verreikende koerswijzigingen in de sociale zekerheid, het arbeidsmarktbeleid, het ontslagrecht, de pensioenen, de sociale werkvoorziening, maatschappelijke ondersteuning, de zorg, het onderwijs en de woningmarkt. En dit allemaal in een korte periode van tweeënhalf jaar. Toen de nieuwe regering aantrad, werd alom rekening gehouden met een snelle val van Rutte II. Geloof in reële ombuigings- en hervormingsprestaties was ver te zoeken in het licht van de korte levensduur van de voorafgaande vier kabinetten onder Balkende en de gedoogcoalitie VVD-CDA-PVV van Rutte I (vgl. Otjes en Voerman, 2014). $\mathrm{Nu}$ de Nederlandse economie midden-2015 eindelijk weer in de lift zit, ziet het er zelfs naar uit dat de huidige regering als 'missionair' kabinet de eindstreep gaat halen van de volgende verkiezingen in het voorjaar van 2017; een prestatie van formaat. 
Een vergelijking met de hervormingscoalities van Ruud Lubbers (19821989) en Wim Kok (1994-2002), die aan de basis stonden van het Nederlandse succes in de jaren 9o, dringt zich op. Maar de verschillen zijn groter dan de overeenkomsten. In de eerste plaats konden de kabinetten van Lubbers en Kok leunen op ruime mandaten in de Eerste en Tweede Kamer. De belangrijkste ontwikkeling in het politieke domein is zonder enige twijfel de toegenomen volatiliteit in kiezersgedrag en regeringsstabiliteit. De huidige regeringscoalitie van VVD en PvdA moet het doen zonder meerderheidssteun in een sterk gepolitiseerde Eerste Kamer. We kunnen dan ook beter spreken van een 'minderheidskabinet' naar Deens voorbeeld. Tijdens de rit zijn de politieke condities voor Rutte II verder verslechterd. Met de grote verliezen bij de Provinciale Statenverkiezingen van 18 maart 2015 voor de regeringscoalitie, en met name de PvdA, is regeren nog moeilijker geworden.

Ook de verhouding met het maatschappelijk middenveld, in de tweede plaats, is van een andere orde dan in de gloriedagen van het poldermodel van weleer. Men name het dalend en vergrijzend lidmaatschap van de Nederlandse vakbeweging heeft ook de verhoudingen tussen werkgevers en werknemers in de polder minder stabiel gemaakt - zo daalde het totale ledental van de vakbeweging van 1,87 miljoen leden in 2010 naar 1,74 miljoen leden in 2015; daarmee bedraagt de organisatiegraad juist minder dan 20 procent op een actieve beroepsbevolking van 8,9 miljoen personen in het tweede kwartaal van 2015. Tegelijkertijd doemt, in de derde plaats, het beeld op van Rutte II als 'vragende partij' richting middenveld (en parlement). Ten tijde van het Akkoord van Wassenaar in het najaar van 1982 was de regering-Lubbers I volledig onafhankelijk van de goedgeorganiseerde sociale partners om desnoods op eigen kracht haar 'no-nonsense' hervormingsambities waar te maken, ook al stond de deur naar de werkgevers en werknemers open. In de schaduw van een sterke regering met een stevig politiek mandaat zochten de sociale partners elkaar op, om aan een van boven opgelegde looningreep te ontkomen.

Door de politieke nood geboren, koos het kabinet-Rutte-Asscher voor een fundamenteel andere polderstrategie, waarbij eerst voor specifieke hervormingen in maatschappelijke kringen steun werd gezocht, waarna 'ad hoc' politiek draagvlak werd gemobiliseerd bij de zogeheten 'constructieve' oppositie en andere partijen in de Tweede Kamer (zie figuur 7.1). Dit tekent een wezenlijk andere 'politiek-maatschappelijke logica' in de Nederlandse polder dan in de gloriejaren 80 en go van de vorige eeuw. Het palet aan 'ad hoc' maatschappelijke akkoorden en politieke afspraken overziend, lijken variabelen als representativiteit en machtsverhoudingen minder belangrijke variabelen dan de specifieke bijdragen die een brede waaier aan 
sociale groepen - niet alleen werkgevers en vakbonden - levert aan reële aanpassingen in de hervormingsagenda. Waarbij tevens wordt geaccepteerd dat sommige partijen in de besprekingen uiteindelijk een bereikt akkoord niet (willen of kunnen) ondertekenen vanwege problemen in de achterban of vanwege beleidsinhoudelijke bezwaren.

Deze nieuwe stijl van pragmatisch corporatisme kan niet los gezien worden van enerzijds de toegenomen diversificatie en differentiatie in de economie en het maatschappelijk verkeer, en anderzijds de ingrijpende Europeanisering van het macro-economisch (monetair en fiscaal) beleid, die in veel opzichten hebben geleid tot een minder eensgezinde en eenduidige prioriteitsbepaling in de beleidsagenda. In de periode van het Akkoord van Wassenaar was, in termen van beleidslogica, nog sprake van een gemeenschappelijk gedragen enkelvoudige probleemdefinitie en instrumentarium (loonmatiging en arbeidstijdverkorting als antwoord op de structurele werkloosheid en stijgende prijsniveaus) in de samenspraak tussen overheid en sociale partners. Een dergelijke overkoepelende hervormingsstrategie werd nog wel door het eerste kabinet-Rutte geambieerd bij het pensioenakkoord van 2010. De prijs van de pensioenhervorming bleek uiteindelijk in de Tweede Kamer en voor de vakbeweging te hoog, zo hoog zelfs dat de FNV bijna aan een identiteitscrisis ten onder ging. Het falen van het pensioenakkoord staat onzes inziens als 'negatief leermoment' aan de basis van wat wij in deze bijdrage pragmatisch 'nieuw Nederlands polderen' noemen.

In dit hoofdstuk presenteren we een institutionele analyse van de Werdegang van de Nederlandse overlegeconomie in de eenentwintigste eeuw. De rest van de bijdrage is als volgt opgebouwd: na deze inleiding

\section{Figuur 7.1 De verschillende akkoorden en hun toepassingstermijnen}

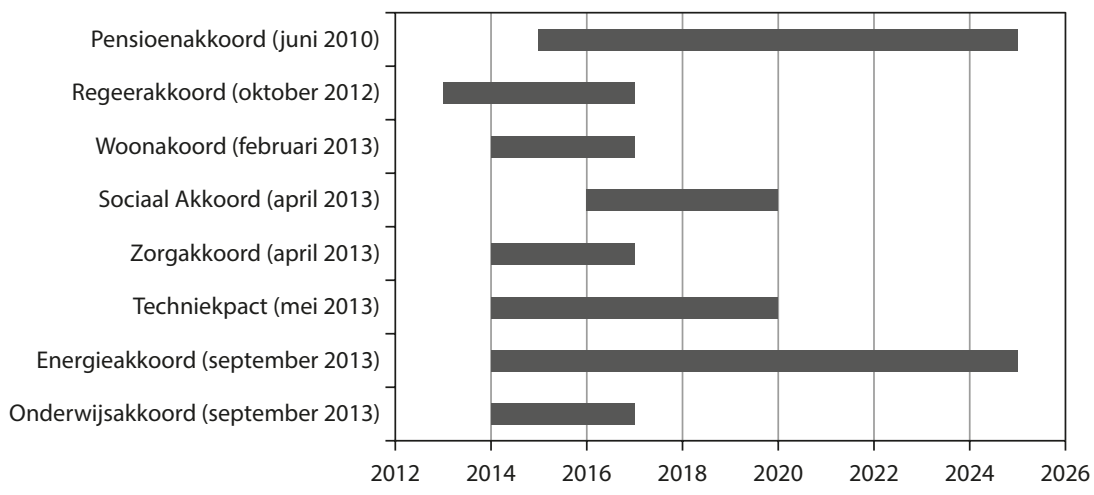


volgt een korte theoretische exploratie over de smalle marges van het onderhandelend bestuur in een sterk geëuropeaniseerde, open politieke economie als de Nederlandse. Aansluitend volgt in paragraaf 3 een duiding van de kater van het vastgelopen pensioenoverleg. In paragraaf 4 analyseren we het Mondriaan-akkoord, dat wij inhoudelijk beschouwen als een belangrijke herdefiniëring van het regeerakkoord op het terrein van de arbeidsmarkt en de sociale zekerheid. In paragraaf 5 behandelen we vijf domeinakkoorden op de terreinen van de zorg, het onderwijs, techniek, wonen en energie. De bijdrage sluit af met een meer exploratieve weging van de toekomstbestendigheid van 'ad hoc' pragmatisch polderen in de Nederlandse kenniseconomie van de eenentwintigste eeuw.

\section{De smalle marges van eenentwintigste-eeuws onderhandelend bestuur en sociaal overleg}

Een van de grondleggers van de vergelijkende Europese politicologie, de Noorse sociaal wetenschapper Stein Rokkan, heeft beargumenteerd dat de besturing van een hoogontwikkelde democratie het beste begrepen kan worden aan de hand van twee pijlers (two tiers): een parlementaire pijler (parliamentary tier) en een maatschappelijke pijler (corporate tier), met respectievelijk politieke partijen en georganiseerde belangen als de drijvende actoren. Voor Rokkan bestond democratisch besturen bovenal uit de evenwichtsoefening tussen de 'parlementaire' en 'maatschappelijke' pijlers in de beleidsontwikkeling. Van doorslaggevend belang voor Rokkan, en later voor Philippe Schmitter en Gerhard Lehmbruch, de founding fathers van de studie naar corporatistisch beleid, was hoe de maatschappelijke pijler is georganiseerd en aan welke spelregels de politieke pijler is onderworpen. In het Amerikaanse pluralisme betreft de maatschappelijke pijler een breed en gevarieerd veld van veel kleine pressiegroepen, die via hun lobbykantoren in Washington D.C. allemaal op ongecoördineerde wijze de nationale beleidsagenda trachten te beïnvloeden. In tegenstelling tot het Amerikaanse pluralisme, kennen de democratieën van het Europese vasteland, behalve Frankrijk en het Verenigd Koninkrijk, hechter georganiseerde maatschappelijke pijlers en overheden die werkgeversorganisaties en de vakbonden als geprivilegieerde gesprekspartners tegemoet treden. De kracht van georganiseerd overleg is volgens Schmitter en Lehmbruch dat overheid en sociale partners op basis van langdurig opgebouwd vertrouwen, afspraken over een bredere en meer voor de lange termijn gerichte beleidsagenda mogelijk maken (Schmitter en Lehmbruch, 1979; Lehmbruch en Schmitter, 
1982). De notie van een 'gedeelde politieke ruimte' (shared public space) van de Britse politiek socioloog Colin Crouch (1993) geeft een goed beeld van de wederkerigheid en de nabijheid van belangenvertegenwoordiging en regeringsbeleid. Door de politieke ruimte te delen en belangengroepen te betrekken bij de ontwikkeling en uitvoering van beleid, staat de overheid in wezen een deel van haar regulerende bevoegdheden - namelijk het gebruik van wettelijke dwangmiddelen en vermogen om bindende overeenkomsten te sluiten en de naleving ervan af te dwingen - af aan organisaties waarover de regering geen directe bestuurlijke zeggenschap heeft. Zo kunnen belangenorganisaties die nauw betrokken zijn bij besluitvormingsprocessen uitgroeien tot public regarding ofwel publiek belang versterkende krachten.

In een van de meest originele empirische studies over deze thematiek, Small States in World Markets uit 1985, laat de Cornell-politicoloog Peter Katzenstein zien hoe de kleine corporatistisch georganiseerde economieën in West-Europa na de Tweede Wereldoorlog proactieve beleidsstrategieën hebben weten te ontwikkelen van enerzijds externe flexibele aanpassing aan veranderingen in de wereldeconomie gebaseerd op een diep verankerde consensus over handelsliberalisering, en anderzijds binnenlandse sociale compensatie, op basis van een breed scala aan sociale programma's gericht op een acceptabele verdeling van de sociale kosten die inherent verbonden zijn aan door de liberalisering afgedwongen economische aanpassing (Katzenstein, 1985). In veel kleine en open economieën, zoals in de Scandinavische landen, de Benelux en Oostenrijk, is de balans tussen economische wendbaarheid en sociale weerbaarheid permanent gespreksonderwerp in stevig verankerde advies- en onderhandelingsfora van centraal overleg tussen de sociale partners in bi- en tripartiete samenspraak met de overheid. Polderinstituties zoals de Sociaal-Economische Raad (SER) als vooraanstaand sociaaleconomisch adviesorgaan van de overheid, en de Stichting van de Arbeid (StvdA) als nationaal platform voor cao-onderhandelingen, zijn in dit opzicht zeker niet uniek in Europa.

Goed gestructureerd overleg tussen overheid en sociale partners heeft volgens Katzenstein het grote voordeel van snel, adaptief en sociaal responsief hervormen, zeker in tijden van crisis. Dat wil zeggen: als alle neuzen programmatisch dezelfde kant op wijzen en belanghebbenden bereid zijn brede steun te geven aan specifieke hervormingen die weleens ten koste gaan van heilige huisjes in de eigen gelederen. Wanneer inhoudelijk-strategische onenigheid overheerst, kunnen sociale conflicten de beleidsontwikkeling gemakkelijk immobiliseren, waardoor responsieve hervormingen in de kiem worden gesmoord (Hemerijck, 1992; Visser en Hemerijck, 1997). Het gaat te ver om te beweren dat beleidsafstemming in 
de maatschappelijke pijler, de parlementaire pijler met voldongen feiten confronteert en de eigen verantwoordelijkheid van de regering uitholt. De regering is eerstverantwoordelijke voor beleid, ongeacht of zij een inhoudelijk advies van de SER opvolgt of naast zich neerlegt, een akkoord tussen werkgevers- en werknemersorganisaties bekrachtigt of met tegenmaatregelen beantwoordt. De Tweede Kamer houdt het recht om op eigen gezag het kabinet ter verantwoording te roepen. In termen van inputlegitimiteit doet de overlegeconomie daarom niets af aan het politieke primaat: de regering regeert en het parlement controleert. Voor wat betreft outputlegitimiteit, komt in de wetenschappelijke literatuur uit de jaren 90 het beeld naar voren dat de consensus-georiënteerde politieke economieën, vanwege de 'publieke status' van werkgevers- en werknemersorganisaties in de beleidsontwikkeling, beter in staat zijn om sociale conflicten te mitigeren, economische crises te beheersen, beleid te coördineren, en daarmee ook betere sociaaleconomische prestaties neer te zetten (zie bijvoorbeeld Rhodes, 2001). Hiertegenover staan kritische geluiden over de stroperigheid van sociaaleconomisch overleg door georganiseerde hindermacht en de ongemakkelijke throughput-legitimiteit van sociale akkoorden, waarbij de sociale partners als insiders in het beleidsbestel ten opzichte van andere maatschappelijke belangen - denk aan de milieubeweging - worden bevoorrecht (vergelijk Schmidt, 2013).

Het is voor onze analyse van belang om onderscheid te maken tussen de 'politiek-maatschappelijke' en de beleidsinhoudelijke of 'programmatische' logica van onderhandelend bestuur en sociaal overleg. De politieke logica verwijst naar de dimensie van verkrijgen van politiek draagvlak voor sociale akkoorden. Een kabinet met een breed politiek mandaat in de Tweede en Eerste Kamer koopt, vanuit de politieke logica van onderhandelend bestuur en sociaal overleg geredeneerd, sociale rust en stabiliteit voor de lange termijn door akkoorden met belangenorganisaties aan te gaan ter ondersteuning van beleid dat parlementair al breed wordt gedragen. Een minderheidskabinet kan desgewenst een omgekeerde politieke strategie hanteren, waarbij eerst maatschappelijke steun voor hervormingen in de maatschappelijke arena wordt verzekerd, alvorens partijen in de politieke arena te verleiden om maatschappelijke afspraken te steunen. Wanneer een minderheidskabinet niet voldoende maatschappelijk draagvlak weet te verwerven, doet het er goed aan om een zo breed mogelijk mandaat in de politieke pijler te verwerven, omdat hervormingen hoogstwaarschijnlijk op stevig maatschappelijk verzet zullen stuiten.

Naast een politieke logica is er altijd sprake van een programmatische logica bij onderhandeld bestuur en sociaal overleg, waarbij inhoudelijke 
beleidsalternatieven (gezamenlijk) worden verkend en ten opzichte van elkaar worden gewogen, als ruilmiddel voor het verkrijgen van politieke steun. Denk in deze context aan de inhoudelijke ruil van loonmatiging voor werkgelegenheid en de verdere normalisering van flexibele arbeid sinds het Akkoord van Wassenaar. Als de dominante interactie-modus in de politieke logica in de poldereconomie onderhandelen (bargaining) is, dan is probleemoplossing (problem-solving) de modus operandi in de programmatische logica van polderen. Op zijn best is polderen 'probleemoplossend onderhandelen', waarbij bestaande normatieve oriëntaties en cognitieve inzichten door georganiseerde interactie tussen politieke en maatschappelijke actoren worden vertaald in een nieuwe programmatische consensus. Een overheid die de politieke ruimte wil delen met maatschappelijke partijen is zich met andere woorden niet alleen bewust van de beperkingen in politiek-hiërarchische doorzettingsmacht om hervormingen ten uitvoer te leggen, maar erkent tevens programmatische beperkingen in kennis, inzicht en overzicht, die bij belangenorganisaties in de maatschappelijke pijler en ook bij de kroonleden in de SER in ruime mate voorradig zijn voor probleemoplossing via onderhandelen.

\section{De EU als derde pijler}

Maar hoe groot zijn de nationale marges voor probleemoplossend onderhandelen in de nasleep van de kredietcrisis? Wat valt er nog uit te ruilen naar programmatisch beleid en politieke steun? De verheviging van de internationale concurrentie; de Europeanisering van economisch beleid, de toegenomen diversiteit aan arbeidspatronen; de verdere afname van organisatiegraad van de vakbeweging; en de toegenomen politieke volatiliteit met de opkomst van het populisme hebben alle de beleidsautonomie en politieke slagkracht van de nationale polderinstituties en actoren aangetast.

De hervormingsagenda's van Lubbers en Kok bestonden uit minutieus uitgewerkte regeerakkoorden die konden worden ondersteund door ruime meerderheden in de parlementaire pijler. Stevige verticale discipline van koepelorganisaties over de lid-organisaties in de maatschappelijke pijler vergemakkelijkte hiernaast het ruilverkeer tussen sociale partners en regering. Sluipenderwijs is het democratisch mandaat van de regering in het parlement smaller geworden, hetgeen de stabiliteit van opeenvolgende coalities sinds de paarse kabinetten danig bemoeilijkt. Voor werkgevers die internationaal opereren is de nationale schaal voor belangenuitruil in de maatschappelijke pijler te klein geworden, en vanwege dalend lidmaatschap is de vakbeweging in een diepe representativiteitscrisis terechtgekomen. 
Het dramatische verloop van het pensioenakkoord in 2009-2011 en de daaropvolgende open leiderschapscrisis bij de FNV zijn hier de uiting van, zoals we in de volgende paragraaf analyseren.

Recente hervormingen in de arbeidsmarkt, de sociale zekerheid en de pensioenen, het zorgstelsel, de woningmarkt, het onderwijs en het klimaatbeleid kunnen niet los gezien worden van de strengere budgettaire kaders die in EU-verband zijn afgesproken sinds de krediet- en Eurocrisis.

Achteraf moeten we constateren dat de Economische en Monetaire Unie (EMU) geheel nieuwe en moeilijk te beïnvloeden bestuurlijke verhoudingen in het leven heeft geroepen. In navolging van Stein Rokkan kunnen we met recht spreken van de toevoeging van een derde pijler van bestuur en beleid, de EU-pijler (European tier), naast de bestaande 'two tiers' van onderhandelend bestuur en sociaal overleg.

Het zogeheten 'Europese Semester' (2010), samen met de afspraken over verscherpt begrotingstoezicht door de Europese Commissie in het kader van het Euro Plus Pact (2011), het Six-Pack (december 2011), het Two-Pack (2013) en het Fiscale Compact (2013), hebben een elementaire bevoegdheid van soevereine staten - het budgetrecht - ondergeschikt gemaakt aan de bestuurlijke autoriteit van de Europese Commissie, waarbij alleen de Europese Raad van regeringsleiders bij gekwalificeerde meerderheid kan interveniëren. Dit is een institutionele waterscheiding. Zo is afgesproken om de conceptbegrotingen van de eurolanden in het voorjaar ex ante te laten beoordelen door de Europese Commissie, inclusief een mandaat om beleidswijzigingen voor te stellen. De Europese 'derde pijler' van bestuur en beleid laat weinig ruimte voor landen-specifieke macro-economische flexibiliteit en houdt geen rekening met het gegeven dat de Europese economieën naar sector-structuur, handelsbalans en institutionele ordening sterk van elkaar verschillen.

De nieuwe budgetregels van de EU zijn sterk restrictief, gericht op het afremmen van de overheidsbestedingen, waarbij economisch tegenvallers onmiddellijk moeten worden gevolgd door procyclische bezuinigingen. Om een beeld te krijgen van de programmatische ingrepen die de Europese instellingen als 'derde pijler' van beleid en bestuur in gedachten hebben voor de overtreders van de budgetregels, spreken de brieven van Mario Draghi en zijn voorganger Jean-Claude Trichet aan het adres van de Ierse, Italiaanse en Spaanse regeringen in nood, boekdelen. De brieven laten een expliciete voorkeur zien voor een 'one-size-fits-all' beleidsmix van bezuinigingen, loonmatiging, decentralisering van collectieve onderhandelingen, arbeidsmarktderegulering, een kleinere verzorgingsstaat en een hogere pensioenleeftijd. Allemaal onderwerpen 
die onder normale omstandigheden onderwerp van nationaal sociaal overleg en beleid zijn.

Vanaf 2012 tekent zich een 'spagaat' af in het macro-economisch beleid van de Eurozone. Enerzijds smoort procyclische begrotingsdiscipline, vastgelegd in het 'Europese Semester', economische groei; anderzijds probeert de onafhankelijke ECB - contre coeur - het deflatiespook af te wenden met lage rentes, 'lender-of-last-resort' interventies, regelrechte monetaire transacties, 'quantitative easing' en andere onorthodoxe maatregelen. Het beperkte mandaat - bewaken van prijsstabiliteit - die de ECB in het kader van de EMU in 1999 had meegekregen, is ondertussen stevig opgerekt, tot groot ongenoegen van Duitse (en ook Nederlandse) centrale bankiers. De euro is weliswaar overeind gehouden, maar de tegenstrijdige beleidsmix van restrictieve bezuinigingswoede in de Eurogroep en radicale geldverruiming door de ECB kan gemakkelijk tot speculatieve bubbels leiden en daarmee een nieuwe kredietcrisis inluiden.

\section{Betekenis van Europa}

Het is evident dat sinds de Eurocrisis de beleidsmarges voor nationale actoren - regeringen, politieke partijen en maatschappelijke spelers - zeer smal zijn geworden. Toch zijn de actoren die opereren in 'parlementaire' en 'maatschappelijke' arena's niet machteloos, en misschien zelfs wel belangrijker geworden in de schaduw van de derde EU-pijler van bestuur en beleid. In de eerste plaats moet worden onderstreept dat beleidssoevereiniteit is overgedragen naar Europese instellingen, zoals de ECB, op basis van democratisch gedragen nationale parlementaire besluitvorming aan de 'input-kant' van het beleidsproces. De meest recente crisismaatregelen leunen bovendien sterk op intergouvernementele besluitvorming door de Europese Raad van democratisch gekozen regeringsleiders. Ten tweede kan de Europese economische integratie niet zomaar een positieve rol worden ontzegd aan de 'output-kant' van beleid. De langetermijnsuccessen van het poldermodel - banen, groei, sociale cohesie en politieke stabiliteit - staan niet los van de intensivering van Europese economische integratie sinds het midden van de jaren 8o. Als de interne markt van de EU niet door Commissievoorzitter Jacques Delors was losgetrokken, was het Akkoord van Wassenaar hoogstwaarschijnlijk minder werkzaam geweest. Van even groot belang om te benadrukken is dat vanaf de jaren 90 zo goed als alle internationale recessies in Nederland zijn bezworen met meer en minder brede sociale akkoorden in de SER en de Stichting van Arbeid, waarin belangrijke aanpassingen in arbeidsregulering, sociale zekerheid 
en pensioenen, en innovaties op het terrein van flexibiliteit en zekerheid duurzaam zijn bekrachtigd (Visser en Van der Meer, 2011), in de schaduw van de verdere intensivering van Europese economische integratie.

\section{De kater van het pensioenakkoord 2010}

Bij het uitbreken van de Grote Recessie in 2008 was het eerste gezamenlijke antwoord van de sociale partners een bipartiete overeenstemming: 'Samen doen wat mogelijk is' (2008). De bedoeling van deze overeenkomst was bij te dragen aan stabiliteit en onderlinge klimaatbeheersing door het ordenen van de beleidsagenda, gericht op de verbetering van de werkgelegenheid. Een echte 'agreement to agree', zoals er in de jaren 2000 wel meer zijn gesloten (Van der Meer en Visser, 2010). Nadat het CPB de groeiverwachtingen voor 2009 fors naar beneden had bijgesteld (er werd plotsklaps een krimp verwacht van 3,5 procent), kwam het tot een nieuw voorjaarsakkoord in 2009, met een bijgestelde loonkostenontwikkeling (van maximaal 1 procent in 2009 en nul procent in 2010, zie Hartveld, 2012). Dat deze eerste reactie op de crisis alsnog rijkelijk lankmoedig was, kent twee oorzaken. Ten eerste werd de ernst van de financiële crisis aanvankelijk, ook in de modellen van het Centraal Planbureau, onderschat. Er was nog geen sprake van noodzakelijke grote bezuinigingen, zoals die zich bij de eerste regering-Rutte zouden aandienen als gevolg van verder tegenvallende cijfers. In tegendeel, de commissie-Bakker (2008) waarschuwde nog voor dreigende tekorten op de arbeidsmarkt vanwege de vergrijzing van de beroepsbevolking. Hiernaast werden er voorbereidingen getroffen voor een stevige kennis- en innovatieagenda, die later door de bezuinigingen grotendeels zijn ingehaald (zie verder).

In de tweede plaats was er verschil van mening aangaande de toekomst van de pensioenen. Begin 2009 plaatste het kabinet-Balkenende IV de toekomstbestendigheid van het pensioenstelsel op de beleidsagenda. Vanwege de demografische druk liet het СРB zien dat op termijn onbeheersbare kosten voor de schatkist konden worden verwacht. Het kabinet deed voorstellen voor wijzigingen in de eerste pijler, de algemene ouderdomsvoorziening, alsook voor de tweede pijler, die van de bedrijfstakpensioenen. Het meest in het oog springende kabinetsvoorstel betreft de verhoging van de AOW-leeftijd naar 67 jaar, met oog op de houdbaarheid van de overheidsfinanciën, de verhoging van de arbeidsparticipatie en de verlaging van de collectievelastendruk. Met de stijging van de pensioengerechtigde leeftijd zou het kabinet tot 4 miljard euro kunnen bezuinigen. Deze gedachte was 
voor de vakbeweging en de linkse politieke partijen (en de PVV) onaanvaardbaar: er mocht niet langer gewerkt worden dan tot 65 jaar. De sociale partners kregen vervolgens een half jaar de tijd (tot oktober 2009) om in de SER alternatieve voorstellen in te brengen. De werkgevers hielden vast aan een stapsgewijze overgang naar 67 jaar, de vakorganisaties FNV en MHP gingen hier echter niet in mee, terwijl de CNV hierover alleen wilde spreken als eerst de feitelijke arbeidsinzet van werkenden tot 65 jaar zou

\section{Tabel 7.1 Chronologie van het pensioenakkoord}

\begin{tabular}{|c|c|}
\hline 7 oktober 2008 & Najaarsakkoord Stichting van de Arbeid: 'Samen doen wat nodig is'. \\
\hline 25 maart 2009 & $\begin{array}{l}\text { 'Voorjaarakkoord Stichting van de Arbeid'. Tot } 1 \text { oktober } 2009 \text { hebben } \\
\text { sociale partners een half jaar de tijd om alternatieven te bedenken }\end{array}$ \\
\hline 21 september 2009 & $\begin{array}{l}\text { Rapport commissie-Don: 'Advies betreffende parameters } \\
\text { pensioenfondsen'. }\end{array}$ \\
\hline 30 september 2009 & $\begin{array}{l}\text { Sociale partners bereiken geen alternatief voor de kabinetsplannen. } \\
\text { Jongerius beschuldigt de werkgevers als 'tuig van de richel'. }\end{array}$ \\
\hline december 2009 & Kabinetsvoorstel voor verhoging pensioenen tot 67 jaar. \\
\hline 19 januari 2010 & Rapport commissie-Frijns: 'Onzekere onzekerheid'. \\
\hline 27 januari 2010 & Rapport commissie-Goudswaard: 'Een sterke tweede pijler'. \\
\hline 20 februari 2010 & Val kabinet-Balkenende IV. \\
\hline 2 maart 2010 & $\begin{array}{l}\text { Kabinet is demissionair. Tweede Kamer verklaart pensioenakkoord } \\
\text { controversieel. }\end{array}$ \\
\hline maart 2010 & $\begin{array}{l}\text { Alternatief voor vakbond (AVV) publiceert 'Pensioen: van poëzie tot } \\
\text { profetie' (over de generatiekloof in de pensioenrechten van jong en } \\
\text { oud). }\end{array}$ \\
\hline 4 juni 2010 & $\begin{array}{l}\text { Stichting van de Arbeid. Pensioenakkoord voorjaar 2010. Nadere } \\
\text { uitwerking pensioenherziening is nodig. }\end{array}$ \\
\hline 30 september 2010 & $\begin{array}{l}\text { Coalitieakkoord 'Vrijheid en verantwoordelijkheid' (VVD-CDA) en } \\
\text { gedoogakkoord (met PVV) van kabinet-Rutte } 1 .\end{array}$ \\
\hline 4 april 2011 & Patstelling bij FNV, Jongerius breekt overleg met werkgevers af. \\
\hline mei 2011 & Minister Kamp van SZW wil AOW-verhoging doorzetten. \\
\hline 13 september 2011 & $\begin{array}{l}\text { Federatieraad FNV verzet zich tegen pensioenplan, ondanks extra } \\
\text { toezegging voor lagere inkomens en zwaardere beroepen. FNV } \\
\text { Bondgenoten en Abvakabo haken definitief af. }\end{array}$ \\
\hline 3 december 2011 & $\begin{array}{l}\text { Dalfsen-beraad van FNV onder leiding van } \mathrm{H} \text {. Wijffels en } \mathrm{H} \text {. Noten: } \\
\text { de FNV wordt opgeheven en De Nieuwe Vakbeweging FNV wordt } \\
\text { opgericht. }\end{array}$ \\
\hline 21 april 2012 & Catshuisbesprekingen afgebroken, einde gedoogsteun PVV. \\
\hline 26 april 2012 & $\begin{array}{l}\text { Kunduz-akkoord, Kabinet-Rutte I met D66, CU, GL. Herziening } \\
\text { pensioenen naar } 67 \text { jaar gaat in per } 2015 \text { in plaats vanaf } 2020 .\end{array}$ \\
\hline 29 oktober 2012 & $\begin{array}{l}\text { Regeerakkoord 'Bruggen slaan', start kabinet-Rutte II. Pensioen- } \\
\text { herziening wordt versneld doorgezet. }\end{array}$ \\
\hline 1 juni 2015 & Ongedeelde FNV van start. \\
\hline
\end{tabular}


stijgen (en de vroegpensionering kon worden gestopt). Om de patstelling te doorbreken werden er twee adviescommissies in het leven geroepen. De commissie-Goudswaard (2010) adviseerde over de toekomstbestendigheid van het stelsel en de commissie-Frijns (2010) legde zich toe op risicobeheer, beleggingsbeleid en governance van de pensioenfondsen.

Na de vroege val van het kabinet-Balkenende IV in februari 2010 brak er voor de sociale partners in de Stichting van de Arbeid een nieuw moment aan om de beleidsagenda naar zich toe te trekken, zodat op 4 juni 2010 in de Stichting van de Arbeid een principeakkoord kon worden bereikt over de pensioenherziening. Er werd overeenkomst bereikt op vier thema's:

1 de verhoging van de AOW-leeftijd naar 67 jaar; eerder stoppen met werken bleef mogelijk, maar onder strengere voorwaarden;

2 de stabilisatie van de pensioenpremies, gezien de stijgende levensverwachting en de onrust op financiële markten;

3 de flexibilisering van pensioencontracten;

4 de verbetering van het toezicht op de pensioenen.

Het nieuw aangetreden minderheidskabinet-Rutte I, met de gedoogsteun van de PVV, wilde de pensioenafspraken uit de 'maatschappelijke pijler' zo snel mogelijk vertalen in wetgeving, maar uiteindelijk stemden FNV Bondgenoten en Abvakabo in de algemene ledenraad van de FNV in september 2011 toch niet in met de plannen. Ook de PVV kon zich niet vinden in de bezuinigingen die noodzakelijk waren om te voldoen aan de hierboven beschreven nieuwe Europese begrotingssystematiek. Nadat onderhandelingen tussen de regering en de PVV in het Catshuis over extra bezuinigingen spaak liepen, en daarmee het eerste kabinet van Mark Rutte ten val kwam, sloten VVD, CDA, D66, GroenLinks en de ChristenUnie op 26 april 2012 een akkoord over miljardenbezuinigingen - het zogeheten Kunduz-akkoord - om het begrotingstekort onder de maximaal toegelaten 3 procent volgens het Stabiliteitspact te brengen, om op die manier een boete uit Brussel van ruim een miljard euro te voorkomen. Hiermee werden de pensioenafspraken onderdeel van de begroting voor 2012. Vanaf 2015 is de pensioenhervorming een feit. Het regeerakkoord kon worden gerespecteerd, de toetsingskaders moesten conform de EU-richtlijnen worden herzien, en de belastingdienst zou de voortgang van de pensioenhervormingen gaan monitoren.

De maatschappelijke prijs van het conflict over de pensioenen was hoog en bracht de FNV aan de rand van de afgrond. Vanwege de economische crisis waren veel vakbondsbestuurders bezig met het onderhandelen van sociale plannen bij bedrijfsreorganisaties. Zo ontstonden er binnen de 
vakorganisaties twee stromingen, die sterk met elkaar wedijverden: de organizers en de polderaars. De organizers wilden de positie van vakorganisaties op de werkvloer versterken, zoals bleek uit de grote acties in de schoonmaak (waar vijftien weken werd gestaakt) en in mindere mate de publieke sector. De polderaars deden er alles aan om achter de schermen toch een akkoord te bereiken. Deze spanning werd uiteindelijk onhanteerbaar. De voorlieden van de vakbeweging moesten constateren dat de achterban niet meer op één lijn kon worden gebracht met de leiding. Een en ander leidde niet alleen tot het vertrek van vakbondsvoorzitter Agnes Jongerius op 23 juni 2012; op die dag werd de FNV afgeschaft. Na een diepe crisis en uitgebreide discussie over verenigingsdemocratie, financiën en de grondslagen van vakbondswerk, werd op 15 mei 2013 de verenigingsstructuur van De Nieuwe Vakbeweging FNV van kracht, en op 1 januari 2015 sloten de meeste vakcentrales zich weer aan bij de ongedeelde FNV.

Het relaas van het pensioenakkoord maakt duidelijk dat het eerste kabinet-Rutte politiek onvoldoende stevig in het zadel zat om de pensioenherziening succesvol door te voeren, en dat het kabinet op onvoldoende maatschappelijk steun kon bogen in de maatschappelijke pijler, doordat met name de vakbeweging uiteindelijk het akkoord, voorbereid in de maatschappelijk pijler, niet breed kon steunen. De beleidslogica werd vervolgens verplaatst naar een prioriteitsstelling door twee boven genoemde ad hoc commissies vanuit de SER. Hierna konden de pensioenafspraken, dankzij het Kunduz-akkoord, door de kamer konden worden geloodst, maar met de grote maatschappelijke prijs van een diepe interne crisis bij het FNV, en daarmee in de Nederlandse overlegeconomie, die zonder een effectieve FNV niet levensvatbaar is. ${ }^{2}$

\section{Het Mondriaan-akkoord}

Na de schipbreuk van het pensioenakkoord moesten de verhoudingen en het onderling vertrouwen tussen de politiek en sociale actoren in de Nederlandse overlegeconomie dringend worden hersteld. In het kielzog

2 Eenzelfde spanning doet zich momenteel voor bij de onderhandelingen en uitwerking van het zogenoemde 'loonakkoord in de publieke sector', waar binnen de context van gedecentraliseerde loononderhandelingen het kabinet met de sociale partners in het publieke domein afspraken heeft gemaakt voor een loonstijging van 5,05 procent en $€ 500$ netto voor 2015 en 2016, die voor een deel gefinancierd worden uit de pensioenvoorzieningen. De FNV heeft dit loonakkoord als enige partij niet ondertekend om de pensioenlast van werkenden niet naar de toekomst te verschuiven. 
van Tweede Kamerverkiezingen van 12 september 2012 werd in de zeer korte periode van vijf weken een regeerakkoord geschreven met een relatief open karakter, voor een coalitiekabinet tussen de VVD en PvdA, de twee grootste partijen bij de verkiezingen, onder leiding van wederom Mark Rutte en met Lodewijk Asscher als vicepremier en minister van Sociale Zaken en Werkgelegenheid. Na een interventie van Mariette Hamer uit de PvdA-fractie werd in de regeringsverklaring 'Bruggen slaan' van 29 oktober 2012 één zin opgenomen over het belang van sociaal overleg en de mogelijkheid van een sociaal akkoord met het nieuwe kabinetRutte-Asscher. Ook werkgeversvoorzitter Bernard Wientjes opperde dat 'er een stabiel kabinet (moet) komen, en stabiliteit kun je in Nederland eigenlijk alleen bereiken als je naast politieke stabiliteit ook sociale stabiliteit hebt' (25 oktober 2012). Die uitspraak werd gedaan op het moment van verdere verdieping van de crisis: het consumentenvertrouwen en de economische groei waren nog niet hersteld (die werden pas positief in 2013) terwijl de werkloosheid sterk toenam (naar maximaal 620.000 in 2014). Bovendien werd door de introductie van het Europese Semester de begrotingsproblematiek in het voorjaar geagendeerd, waardoor het voorjaarsoverleg in 2012 ten opzichte van het najaarsoverleg aan betekenis zou winnen. Tegen deze achtergrond is het dan ook niet verwonderlijk dat premier Mark Rutte, vicepremier Lodewijk Asscher, vakbondsvoorzitter Ton Heerts en werkgeversvoorman Bernard Wientjes twee maanden in relatieve beslotenheid aan het Mondriaan-akkoord hebben gewerkt. En voor het eerst na het fiasco van het Pensioenakkoord uit 2010, steunde de hele vakcentrale FNV het nieuwe sociaal akkoord. Mede daarom noemde premier Rutte het akkoord 'historisch': 'een akkoord van het vertrouwen'. De oppositie echter deed de nieuwe afspraken tussen overheid en sociale partners af als 'vertragingsakkoord' en als een 'hopen-op-groei'-akkoord (Pechtold).

Het sociaal akkoord zelf bevat een reeks aan sociaaleconomische maatregelen om de stijgende werkloosheid het hoofd te bieden en verdergaande bezuinigingen in de openbare financiën te voorkomen. Door het akkoord kon een verder bezuiniging van 4,3 miljard euro worden afgewend en kon het begrotingstekort conform de Europese normstelling toch onder de Europese norm van 3 procent van het bruto binnenlands product blijven. Leidend voor het Mondriaan-akkoord waren niet zoals in de jaren 80 en 90 precies gemarkeerde procentuele kaders voor de loonruimte (al stijgen de salarissen in de publieke sector volgens de regeringsverklaring niet). Ook was er geen sprake van belastingtechnische afspraken over de pensioencorrectie en overbrugging van de vervroegde uittreding (zoals 
in het pensioenakkoord). Het gaat in dit sociaal akkoord eerder om gemeenschappelijke uitgangspunten en beleidsvoornemens op de terreinen van de toekomst van de arbeidsmarkt en sociale zekerheid: er komt een actievere aanpak om werkloosheid te voorkomen en mensen van werk naar werk te helpen, bij voorkeur voordat ze aanspraak moeten maken op de WW. De maatregelen komen neer op het volgende: het ontslagrecht werd vereenvoudigd (de kantonrechtersroute wordt geschrapt, de UWV-route blijft bestaan). Werknemers voor wie ontslag dreigt, krijgen recht op een vergoeding, die gebruikt kan worden voor scholing voor een nieuwe baan. Afgesproken werd dat de maximale duur van de (publiek gefinancierde) WW vanaf 2016 stapje voor stapje - met één maand per kwartaal - wordt teruggebracht, zodat de WW vanaf 2019 wordt gemaximeerd tot twee jaar. De intentie is dat werkgevers en werknemers per cao een aanvullend $\mathrm{WW}$-jaar kunnen overeenkomen, waardoor zij meer regie krijgen over de besteding van de WW-gelden. Hiernaast wordt de positie van werknemers met tijdelijke contracten versterkt. Schijnconstructies worden harder aangepakt, hiervoor worden extra inspecteurs ter beschikking gesteld. Bedrijven en overheden gaan mensen met een arbeidsbeperking aan een baan helpen. Leidend is de gedachte een sluitende ketenaanpak te ontwikkelen waarbij de nadruk ligt op het voorkomen van werkloosheid (preventie) en, als dat niet lukt, op het weer aan werk helpen van werkzoekenden (re-integratie). De duurzame participatie van (gedeeltelijk) gehandicapten moet worden bevorderd.

\section{Tabel 7.2 Maatregelen voortkomend uit het Mondriaan-akkoord}

\begin{tabular}{|c|c|}
\hline 1 januari 2013 & $\begin{array}{l}\text { Overbruggingsregeling AOW voor personen die al vroegpensioen } \\
\text { genieten wordt met terugwerkende kracht iets verruimd. }\end{array}$ \\
\hline $2014-2015$ & $\begin{array}{l}\text { Er komt twee maal } 300 \text { miljoen beschikbaar voor sectorplannen } \\
\text { (co-financiering). }\end{array}$ \\
\hline 1 januari 2015 & Beperking van toegang tot Wajong. \\
\hline 2014-2026 & $\begin{array}{l}\text { Stapsgewijs extra banen voor mensen met een beperking: } 100.000 \text { in } \\
\text { marktsector en } 25.000 \text { in overheidssector. }\end{array}$ \\
\hline 1 januari 2015 & Geen nieuwe instroom in WSW meer. \\
\hline 1 juli 2015 & Invoering nieuwe Wet werk en zekerheid. \\
\hline 1 januari 2016 & Modernisering ontslagrecht. \\
\hline 1 januari 2016 & Herdefiniëring begrip Passende arbeid. \\
\hline $\begin{array}{l}1 \text { januari } 2016 \text { - } \\
1 \text { juli } 2019\end{array}$ & Stapsgewijze reductie van de WW naar 24 maanden.* \\
\hline 2020 & Perspectief op vorming van 35 regionale werkbedrijven. \\
\hline
\end{tabular}

Bron: SZW, overzicht van maatregelen sociaal akkoord

* In het regeerakkoord is een stijging van de WW-premies van 1,3 miljard euro opgenomen. 
De strategische ambitie van het Mondriaan-akkoord was tweeledig. Voor het kabinet stond politieke en maatschappelijke steun voor belangrijke sociaaleconomische beleidshervormingen voorop, en natuurlijk de ingrijpende versoberingen. Voor Bernard Wientjes en Ton Heerts was het na de kater van het pensioenakkoord evengoed te doen om verbeteringen in de arbeidsverhoudingen en het overlegklimaat. Twee jaar later kunnen we constateren dat de hervormingsambities die ten grondslag lagen aan het sociaal akkoord weliswaar grotendeels zijn omgezet in wetgeving, maar dat de arbeidsverhoudingen er desondanks niet stabieler op zijn geworden. Het blijft guur op het terrein van de arbeidsvoorwaardenvorming. Veel cao's expireren en worden niet verlengd. Veel vakorganisaties staken of maken zich zorgen over de positie van werknemers aan de onderkant van de arbeidsmarkt, waar bedrijven hun personeelsinzet flexibiliseren - in de vorm van 'misstanden zoals uitbuiting en schijnconstructies' (Heerts, 19 februari 2015). Werkgevers zoeken juist naar nieuwe verbindingen met het personeel, waarvoor ze graag 'op dialoog gebaseerde' en 'innovatieve' overeenkomsten sluiten met hun medewerkers. De AWVN stelt vraagtekens bij de 'houdbaarheid van instituties'. Het cao-instrument kan in deze visie nog lang mee, maar dat veronderstelt wel een nieuwe structuur van onderhandelingen, een meer participatief proces van omgang tussen cao-partijen, met actieve inbreng van de achterban en een nieuwe inhoud van cao's (met meer loondifferentiatie en ruimte voor demotie).

Andere ideeën uit het sociaal akkoord blijken op het moment van schrijven (zomer 2015) mondjesmaat van de grond te zijn komen. De bedoeling van het sociaal akkoord is om in lijn met de veranderende verantwoordelijkheidsverdeling tussen staat en markt, de sociale infrastructuur op de arbeidsmarkt te herijken voor de bevordering van de werkzekerheid, maar dat vraagt om andere organisatieprincipes: regionale in plaats van de gebruikelijke sectorale organisatie van de werknemers- en werkgeversverenigingen.

De in het akkoord opgenomen instrumenten van de bevordering van (intersectorale) mobiliteit, zodat werknemers makkelijker kunnen overstappen van een krimpsector naar een groeisector, blijven steken. Hetzelfde geldt voor de voorstellen om de sectorale trainingsfondsen meer open te stellen voor intersectorale mobiliteit. Dat is gelukt in het goed draaiende mobiliteitscentrum van de creatieve sector $\left(\mathrm{C}_{3}\right)$ en in de uitzendbranche (STOOF), maar systematische afspraken over(inter)sectorale cao-afspraken, gericht op behoud van werkgelegenheid, inzetbaarheid en combinaties van arbeid en zorg, zijn sinds 2013 nauwelijks verder ontwikkeld. De beleidsvraag is of de op sectorale basis georganiseerde O\&O-fondsen die de inhoudelijke vernieuwing van de arbeidsverhoudingen binnen een sector agenderen, 
ook voldoende mobiliteit tussen sectoren mogelijk kunnen maken (Van der Meijden en Van der Meer, 2013). De nieuwe sectorplannen waarin minister Asscher 6oo miljoen euro investeert hebben hieraan nog niet veel (werkgelegenheid) toegevoegd. Werkgevers moeten alle zeilen bijzetten om hun plan om 7500 nieuwe banen te creëren voor gehandicapten te realiseren.

In de praktijk komen veel voornemens uit het sociaal akkoord neer op een verdere decentralisatie van het sociaal beleid naar het gemeentelijk niveau, waarbij 35 regionale werkbureaus een centrale rol moeten krijgen. Daar komt de invoering van de Participatiewet bij, met een bundeling van de Wajong, Wet sociale werkvoorziening en Wet werk en bijstand. Met andere woorden: er komen veel verantwoordelijkheden samen op gemeentelijk niveau. De decentralisatie raakt met name groepen van laaggekwalificeerde jongeren, waar de werkloosheid zich concentreert. Dat werpt nog een ander licht op het sociaal akkoord, dat symbolisch genoeg op het ROC Mondriaan in Den Haag werd ondertekend. De conclusie moet zijn dat de jeugdwerkloosheid door de maatregelen in het akkoord en door de tijdelijk ingestelde gelijknamige taskforce onder leiding van Mirjam Sterk nog niet is teruggelopen (Bekker et al., 2015).

Wat ten slotte nog niet lukt, is het terugbrengen van het aantal tijdelijke contracten. Vanaf 1 juli 2015 zijn binnen de nieuwe Wet werk en zekerheid nog maar twee (dat was drie) opeenvolgende aanstellingen toegestaan, maar tot op heden zijn er geen indicaties dat daardoor het aantal vaste banen toeneemt (zie hoofdstuk Boonstra in deze bundel).

Samengevat resulteert het beeld dat de sociale partners de regeringsverklaring op het terrein van de arbeidsmarkt met succes inhoudelijk hebben weten te amenderen. De FNV heeft dankzij het sociaal akkoord aan positie en status in de Nederlandse overlegeconomie herwonnen, maar is niet in staat geweest met de werkgevers tot verdere concrete uitwerkingen van het Mondriaan-akkoord te komen. In cao-land is er veel strijd en op de arbeidsmarkt hekelde de nieuwe werkgeversvoorzitter Hans de Boer de mentaliteit van werkzoekenden recent als 'labbekakkers'. Op andere momenten heeft hij gepleit voor een commissie die gaat praten over de toekomst van de arbeidsmarkt buiten de kaders van de overlegeconomie om, onder het mom van 'oude structuren stollen, soms moet je eruit' (Het Financieele Dagblad, 23 februari 2015). Onduidelijk is of De Boer sprak namens VNO-NCW. Het beeld lijkt te kantelen: waar voorheen de vakbeweging van radicalisering kon worden beticht, lijken nu eerder de Nederlandse werkgevers te radicaliseren. Geen van beide is goed voor behoud van de Nederlandse overlegeconomie. 


\section{De domeinakkoorden zorg, onderwijs, wonen, techniek en energie}

Naast het Mondriaan-akkoord, is het opmerkelijk hoe het kabinet-Rutte II in kort tijdsbestek een vijftal 'ad hoc' akkoorden tot stand heeft gebracht met domein-specifieke maatschappelijke partijen, vakbonden, brancheorganisaties en belangengroepen, op de terreinen van zorg, onderwijs, techniek, wonen en energie, waarvoor geen formele overlegstructuur bestaat. In het onderstaande analyseren we deze akkoorden, die met uiteenlopende coalities tot stand zijn gebracht in de nasleep en niet geheel onafhankelijk van het sociaal akkoord.

\section{Zorgakkoord 2013 en 2014}

Net als bij het Mondriaan-akkoord was de directe aanleiding voor het zorgakkoord van 24 april 2013, twee weken na de ondertekening van het sociaal akkoord, de heftige reactie op het regeerakkoord van het nieuw aangetreden kabinet-Rutte II, waarin verregaande bezuinigingen werden voorgesteld op de curatieve en langdurige zorg, mede om aan de Europese budgettaire verplichtingen te voldoen. Staatssecretaris Van Rijn van VWS stelde een bestuurlijke regiegroep in om mee te denken over de uitvoering van de bezuinigingen, met (beperkte) ruimte voor alternatieven. Voor deze buitenparlementaire overleggroep werden domein-specifieke vertegenwoordigende groepen uitgenodigd, waaronder ActiZ, GGZ Nederland, VGN, NVZ, NFU en BTN. Namens de werknemers waren de Abvakabo FNV, CNV, MHP, NU'91 en FBZ betrokken.

Het eerste zorgakkoord van 24 april 2013, ondertekend door de minister en staatssecretaris met de brancheorganisaties en de vakorganisaties kende een sterke oriëntatie op de arbeidsmarkt in de zorgsector. Net als bij het sociaal akkoord werd nadrukkelijk getracht om de loonontwikkeling en werkgelegenheidseffecten uit het regeerakkoord te 'verzachten' door baan-naar-baanbegeleiding, herscholing door sectorplannen en activeringsmaatregelen. De sociale partners wisten zich gesterkt door de institutionele clausule van het 'recht op vrije onderhandelingen' in de zorgsector, waardoor de nullijn, opgenomen in het regeerakkoord, van tafel kon. Uiteindelijk leverde het akkoord een herschikking van bezuinigingsposten op ter waarde van ongeveer 1,1 miljard euro op de langdurige zorg en de thuiszorg. Andere maatregelen waren meer hbo-verpleegkundigen met mogelijkheid tot hogere salariëring, een compensatie van de korting op de 
jeugdzorg, naast een verhoging van de middelen voor de huishoudelijke verzorging met 35 procent ten opzichte van het regeerakkoord.

Om het akkoord binnen de afgesproken budgettaire kaders te financieren werd de incidentele looncomponent van 2014 tot 2017 bevroren, waarmee ongeveer de helft van het financiële beslag het akkoord kon worden gedragen. De andere helft is ingevuld door een tariefmaatregel op de AWBZ en het Budgettair Kader Zorg. Voor de Abvakabo, de grootste werknemersvertegenwoordiger aan tafel, waren de maatregelen ontoereikend, omdat in hun ogen de bezuinigingen onevenredig werden afgewenteld op werknemers.

Het sluiten van het zorgakkoord 2013 met maatschappelijke partijen was niet afdoende om de parlementaire oppositie te overtuigen. Noodzakelijke onderhandelingen in de parlementaire pijler resulteerden in het tweede zorgakkoord, daterend van 17 april 2014, ondertekend door kabinet en D66, CU en SGP, waarin een structurele toezegging werd gedaan van 360 miljoen euro voor de langdurige zorg, aflopend tot structureel 200 miljoen vanaf 2017 .

Bij het debat in de Eerste Kamer bleek de politieke kwetsbaarheid van deze constructie, toen senator Adri Duivesteijn met twee collega's tegen de vrije artsenkeuze in de zorgverzekeringswet van minister Schippers stemde. Hoewel deze wet losstaat van de maatschappelijke (2013) en politieke (2014) zorgakkoorden, bleek toen hoe de politieke logica van heronderhandeling voor het kabinet noodzakelijk was om een afgezwakte wet toch door de Eerste Kamer te loodsen en de legitimiteit te behouden om door te regeren.

\section{Woonakkoord}

Het woonakkoord werd op 17 december 2013 door een krappe meerderheid in de Eerste Kamer aangenomen. Het is daarmee een akkoord uit de parlementaire pijler, maar een met belangwekkende maatschappelijke antecedenten. In maart 2010 riep de Vereniging Eigen Huis (VEH) op om te komen tot een nationaal woonakkoord op basis van twee uitgangspunten: (1) een integrale aanpak over de gehele breedte van de woningmarkt, en (2) een partij-overstijgende aanpak om een langdurige beleidstransitie te realiseren. Een maand later publiceerde de SER een rapport waarin het adviescollege spreekt over de onwenselijkheid van inkomensherverdeling door overheidsingrijpen. Met name de hypotheekrenteaftrek verstoort volgens de SER de markt, met als gevolg een te hoge loan-to-value ratio, die huisbezitters te weinig beschermt tegen nadelige macro-economische schokken. Binnen de sociale huursector zouden de huren moeten worden 
verhoogd om de particuliere huursector te kunnen laten concurreren en scheefwonen tegen te gaan.

Alhoewel de brede probleemformulering van de SER een integraal woningmarktbeleid op de politieke agenda plaatste, wilde het kabinet-Rutte I niet tornen aan de hypotheekrenteaftrek. Pas met het Kunduz-begrotingsakkoord (26 april 2012) tussen VVD, CDA, GroenLinks, ChristenUnie en D66 werd een aanzet gegeven tot het verplichten van annuïtair aflossen en het verlagen van de loan-to-value ratio. Op 23 mei 2012 presenteerden vier grote maatschappelijke organisaties uit de woningmarkt een woonakkoord genaamd 'Wonen 4.o'. De Nederlandse Vereniging van Makelaars (NVM), Vereniging Eigen Huis (VEH), Aedes namens de sociale huursector, de Woonbond en VastgoedPro en VBO riepen op tot een pakket van maatregelen om de woningmarkt over de gehele breedte te hervormen. De voorstellen hielden het geleidelijk afbouwen van de hypotheekrenteaftrek en het langzaam verhogen van de huren in. In het regeerakkoord dat in oktober 2012 werd gesloten tussen PvdA en VVD werden meer ingrijpende maatregelen gepresenteerd. De aanhoudende crisis en het tot stilstand komen van de woningmarkt, met een forse teruggang in productie en werkgelegenheid, droegen bij aan het besef van urgentie. Er werd besloten tot het terugschroeven van de hypotheekrenteaftrek en het instellen van een verhuurdersheffing, die betaald moest worden met voorgestelde huurverhogingen, gespecificeerd naar inkomensgroep. Uiteindelijk konden niet alle partijen uit het Kunduzakkoord zich vinden in de nieuwe maatregelen. De steun van GroenLinks en het CDA werd verruild voor die van de SGP. Op 13 februari 2013 werd het akkoord in de vorm van een brief van minister Blok aan de Tweede Kamer gepresenteerd. Het woonakkoord werd in de Eerste Kamer definitief gecodificeerd op 17 december 2013, na korte ophef omdat Adri Duivesteijn tegen het akkoord dreigde te stemmen. Om senator Duivesteijn tegemoet te komen bracht minister Blok enkele aanpassingen aan.

Programmatisch is het woonakkoord van grote betekenis, omdat hiermee het decennialange politieke taboe op sleutelen aan de hypotheekrenteaftrek werd doorbroken. Naar de toekomst wordt annuïtair aflossen verplicht als voorwaarde voor belastingaftrek. Huren werden inkomensafhankelijk verhoogd om scheefwonen tegen te gaan. En met additionele fiscale ingrepen worden kwetsbare groepen zoals ouderen, studenten, lagere inkomens en gehandicapten gecompenseerd. Zoals gezegd is het woonakkoord een politiek akkoord, maar een dat programmatisch in de maatschappelijke pijler werd voorbereid. Maatschappelijke actoren, netwerken en hun expertise stonden aan de basis van 'integrale hervorming' van de Nederlandse woonmarkt. 


\section{Onderwijsakkoord 2013}

Het onderwijsakkoord 'De route naar een geweldig onderwijs' is in september 2013 gesloten door het kabinet met de organisaties van werkgevers en werknemers in de diverse onderwijssectoren. Het onderwijsakkoord kan worden beschouwd als een product van de nieuw opgerichte Stichting van het Onderwijs, waarin werkgeversverenigingen en vakorganisaties elkaar en het kabinet ontmoeten. Het onderwijsakkoord is ondertekend door minister en staatssecretaris, de voorzitter van vijf werkgeverskoepels en drie vakorganisaties in het onderwijs. Saillant detail is dat de AOB, de onderwijsorganisatie van de FNV, het onderwijsakkoord niet heeft getekend na een conflict over de aanpassing van de vroegpensioenregeling. In het vervolg is de FNV wel weer ondertekenaar geweest van de cao's.

Het onderwijsakkoord bestaat uit tien pagina's zorgvuldig geformuleerde tekst, aangevuld met handtekeningen en een financiële bijlage. Het akkoord is te beschouwen als een onderhandelingsresultaat dat wordt uitgewerkt in sectorale bestuursakkoorden van de overheid met de werkgeverskoepels (eerst 'prestatieafspraken' en later 'kwaliteitsafspraken' genoemd). Dit biedt een kader voor de cao-tafel van werkgevers en werknemers in het primair, voortgezet, middelbaar en hoger beroepsonderwijs en voor de universiteiten. Kenmerkend voor het akkoord is dat alle bestuurlijke afspraken en cao-uitkomsten 'in samenhang worden getoetst aan deze kaderafspraken en aan het regeerakkoord', waarna in de periode tot 2017 intensiveringsmiddelen van 689 miljoen (uit het regeerakkoord) en de 256 miljoen voor het funderend onderwijs (uit de motie Van Haersma Buma) beschikbaar worden gesteld. Twee maal per jaar wordt de voortgang besproken.

De doelstellingen van het onderwijsakkoord richten zich op het verbeteren van de inhoud en kwaliteit van het onderwijs, aan de hand van thema's als de zeggenschapsverhoudingen, de mate van professionalisering van docenten, de relatie met de lerarenopleidingen, het op orde houden van de lesbevoegdheid, en andere vormen van deskundigheidsbevordering. Ook is er aandacht voor werkdruk en de verdeling van werkuren. Dit alles wordt samengenomen onder de noemer 'kwaliteitscultuur' als 'voorwaarde om te komen tot een professionele leergemeenschap'.

Ook zijn er arbeidsvoorwaardelijke afspraken: 'Bij een aantrekkelijk beroep horen ook aantrekkelijke arbeidsvoorwaarden.' De modernisering daarvan is een taak voor de cao-tafel. Wel worden afspraken gemaakt voor de afschaffing van de seniorenregeling (in ruil voor een overgangsmaatregel), en nadat de nieuwe cao's tot stand zijn gekomen, belooft het kabinet extra middelen investeren. Dat leidt ertoe dat in de zomer van 2014 
voor het eerst sinds vijf jaar een cao-stijging van 1,2 procent is afgesproken (en de nullijn wordt verlaten). Over de balans tussen vaste en flexibele arbeidsovereenkomsten wordt niets anders opgemerkt dan dat dit thema in de geest van het sociaal akkoord wordt uitgewerkt aan de cao-tafel.

De politieke logica is dat ook hier de overheid de vragende partij was die de bijdrage van de sociale partners nodig had om te komen tot een hoge kwaliteit van dienstverlening (...). Mensen in de voorste linie van het onderwijs, in de zorg en bij de politie moeten trots kunnen zijn op hun werk en zich gesteund weten door hun leidinggevenden' (Regeringsverklaring, 2012, p. 2). Programmatisch is het de ambitie om het onderwijs op een hoger niveau te brengen, waar de scholen dus zelf verantwoordelijk voor zijn. Het akkoord spreekt hier over het 'morele kompas' met als doelstelling de 'professionaliteit' en de 'stevigheid van bestuur en intern toezicht' te versterken waar dat de laatste jaren 'tekort is geschoten'. Het is voor het kabinet lastig de resultaten van al deze inspanningen te beoordelen, omdat er voor de verschillende onderwijssectoren verschillende routes denkbaar zijn om een 'geweldig onderwijs' te bereiken, terwijl leraren zelf van mening zijn dat de politiek zich al veel te veel met het onderwijs bemoeit.

\section{Het Nationaal Techniekpact 2020}

Toen aan het einde van de jaren 2000 door de kabinetten-Balkenende een kennis- en innovatieagenda werd opgesteld, werd duidelijk dat de verschillende inspanningen uit het verleden, van de commissie-Wagner tot aan stimuleringsprogramma's als 'Pieken in de Delta', onvoldoende effect sorteerden om verdere teruggang van het aantal studenten in de bètawetenschappen tegen te gaan. Bij de kabinetsformatie van Rutte I namen de werkgevers het heft in handen en brachten de innovatiegelden van het ministerie van OCW naar het ministerie van EZ: het 'topsectoren'beleid was geboren. Per sector werd een human capital agenda opgesteld. In het techniekpact van 13 mei 2013 werd deze strategie verder uitgewerkt. Het akkoord is een product van vele partijen: drie ministers en een staatssecretaris, alle schoolorganisaties en diverse sociale partners. In totaal staan er zestig handtekeningen onder het pact, inclusief die van astronaut André Kuipers als ambassadeur. Dit 'doe-pact' richt zich op het leren en werken in de techniek, voor alle jongeren van 4-18 jaar, in de volle breedte van het onderwijs. Doel is het aanleren van vaardigheden als creativiteit, ondernemingszin, probleemoplossend vermogen, samenwerking, initiatief, leiderschap en ict-vaardigheden. Het techniekpact verbindt de werelden van EZ, OCW en SZW en moet aangrijpen op regionaal niveau. De realiteit is 
dat daar al samenwerkingsprogramma's waren, die onder deze vlag verder worden ontwikkeld (Twente, Brainport Eindhoven, Limburg, Wageningen, Haaglanden et cetera).

Het techniekpact komt niet direct voort uit een politieke noodzaak om het kabinet in het zadel te houden en bezuinigingen te schragen, het gaat eerder om een top-down ontwikkelde vernieuwingsagenda. Beleidsinhoudelijke sturing vindt niet alleen plaats door persoonlijke commitments (Doekle Terpstra als aanjager), maar vooral ook door te voorzien in financiële middelen die op lokaal niveau in competitie worden gebracht in de vorm van publiek-private samenwerkingen. Opvallend is dat in het techniekpact de gezamenlijke ambities open zijn gehouden, hetgeen ook past bij bestaande verschillen binnen en tussen economische sectoren. Er is wel in kwantitatieve zin sprake van evaluatie van het aantal extra studenten en bereikte bedrijven, maar het ontbreekt vooralsnog aan kwaliteitscontrole op concrete vernieuwingen in onderwijskundige of economische zin.

\section{Nationaal energieakkoord voor duurzame groei}

Dat in de SER op 6 september 2013 een energieakkoord gesloten zou worden, ondertekend door 47 organisaties, kwam onverwacht. Het energieakkoord is net als het techniekpact geen hervormingsakkoord - anders dan de overige akkoorden die we hier bespreken - maar eerder een investeringsagenda.

Aanleiding is dat ondanks alle inspanningen van de vorige ministers van Milieubeheer, Nederland bij lange na niet in staat is zijn Europese milieudoelstellingen voor 2020 te behalen: minder energie verbruiken, minder $\mathrm{CO}_{2}$ uitstoten en meer alternatieve energiebronnen ontwikkelen. De SER werd het podium voor politieke articulatie waar, onder leiding van toenmalig voorzitter Wiebe Draijer, verschillende maatschappelijke organisaties elkaar konden vinden om uitwerking te geven aan de Kamermotie Verburg-Samsom uit 2011: een Nationaal energie-transitieakkoord.

Het Nationaal energieakkoord staat een integrale aanpak voor, gericht op besparing van het energieverbruik van 1,5 procent per jaar en een sterke toename van hergebruik van energiebronnen. De organisatie 'Nederland krijgt nieuwe energie' wordt als motor achter het akkoord gezien. De SER tekende vervolgens een unaniem advies 'Naar een energieakkoord voor duurzame groei', in een vergadering die werd bijgewoond door het hoogste aantal bezoekers in de geschiedenis (16 november 2012). Daarna startte een breed proces met brainstormsessies, conferenties en online-consultatie, dat tien maanden later uitmondde in het energieakkoord tussen zeer verschillende partijen. De milieubeweging wist te bedingen dat de kolencentrales 
uit de jaren 80 zouden worden gesloten in ruil voor belastingvrijstelling op de huidige energieproductie. Voor de sociale partners was van belang dat het akkoord tot nieuwe investeringen en daarmee werkgelegenheid zou moeten leiden. Het kabinet investeerde 150 miljoen euro in een 'revolverend fonds voor energiebesparing' om particuliere investeringen uit te lokken, oplopend tot 450 miljoen euro. Hiernaast wordt 400 miljoen euro geïnvesteerd aan subsidies voor het energieneutraal verbouwen in de sociale huursector. De beleidshorizon van het akkoord reikt ver. Op middellange termijn (2020, 2023) moeten de investeringen renderen en op de lange termijn (2050) moet Nederland energieneutraal zijn. Voor toezicht op de voortgang van de plannen werd een speciale borgingscommissie in het leven geroepen, onder leiding van oud-minister Ed Nijpels, die consultatie en feedback-ronden organiseert om alle partijen bij de les te houden.

\section{Weging en vooruitblik}

Het kabinet-Rutte-Asscher zal net als de kabinetten-Lubbers en -Kok de geschiedenis ingaan als een 'hervormingscoalitie'. Het palet van recente akkoorden en hervormingen laat enerzijds een revitalisering van de overlegeconomie zien, maar anderzijds ook een duidelijke verschuiving in de modus operandi van onderhandelend bestuur en sociaal overleg, weg van de grote sociale akkoorden op basis van een breed politiek-maatschappelijk draagvlak à la Wassenaar naar een reeks van 'ad-hoc' afspraken in onderscheiden beleidsdomeinen. Hiervoor is gericht draagvlak gezocht in de maatschappelijke en parlementaire pijlers van onderhandelend bestuur, in lijn met ambitieuze hervormingsambities en in de schaduw van stringente budgettaire randvoorwaarden uit de EU-pijler van beleid. In tabel 7.3 vatten we ambities en betekenis van de akkoorden samen. We concluderen dat de diverse akkoorden duidelijke verbeteringen, nuanceringen, en temporiseringen en intensiveringen in de hervormingen hebben aangebracht ten opzichte van het nogal overhaast beklonken regeerakkoord 'Bruggen Slaan' in het najaar van 2012.

Binnen de Europese randvoorwaarden heeft eerst het kabinet-Rutte I in de Kunduz-coalitie, en later het kabinet-Rutte II met zijn open regeerakkoord, maatschappelijke organisaties uitgenodigd om mee te denken over de invulling van de hervormingsambities, waarbij, vanwege het ontbreken van een meerderheid in de Eerste Kamer, tegelijkertijd ook rekening werd gehouden met de wensen van de 'constructieve oppositie'. Hierdoor werd maatschappelijk draagvlak verbreed en politieke steun verstevigd 
Tabel 7.3 Programmatische vergelijking van de diverse akkoorden

\begin{tabular}{|c|c|c|c|}
\hline $\begin{array}{l}\text { Akkoord: mate van } \\
\text { hervorming }\end{array}$ & $\begin{array}{l}\text { Bezuinigingen / } \\
\text { investeringen }\end{array}$ & $\begin{array}{l}\text { Betekenis voor } \\
\text { arbeidsverhoudingen }\end{array}$ & Voortgangscontrole \\
\hline $\begin{array}{l}\text { Pensioenakkoord: } \\
\text { overgang naar langer } \\
\text { werken }\end{array}$ & $\begin{array}{l}\text { Latere pensio- } \\
\text { nering, inzet op } \\
\text { inzetbaarheid }\end{array}$ & $\begin{array}{l}\text { Strijd tussen } \\
\text { generaties }\end{array}$ & $\begin{array}{l}\text { DNB (en } \\
\text { pensioenkamer) }\end{array}$ \\
\hline $\begin{array}{l}\text { Sociaal akkoord: } \\
\text { nieuwe contouren } \\
\text { arbeidsmarktbeleid }\end{array}$ & $\begin{array}{l}\text { Extra bezuinigingen } \\
\text { in openbare } \\
\text { financiën afgewend; } \\
\text { verdere ombui- } \\
\text { gingen gericht op } \\
\text { preventieve aanpak } \\
\text { arbeidsmarktbeleid }\end{array}$ & $\begin{array}{l}\text { Conflict om } \\
\text { verhouding tussen } \\
\text { vaste en flexibele } \\
\text { banen; en tussen } \\
\text { goede en uitgeklede } \\
\text { cao's }\end{array}$ & $\begin{array}{l}\text { SZW / Sociale } \\
\text { partners in Stichting } \\
\text { van de Arbeid }\end{array}$ \\
\hline $\begin{array}{l}\text { Onderwijsakkoord: } \\
\text { introductie } \\
\text { lerarenagenda }\end{array}$ & $\begin{array}{l}\text { Herschikking binnen } \\
\text { oCW-begroting; } \\
\text { uiteindelijk inves- } \\
\text { teringen, maar wel } \\
\text { voorwaardelijk } \\
\text { (afhankelijk van } \\
\text { cao-akkoorden). }\end{array}$ & $\begin{array}{l}\text { Aanzet tot } \\
\text { professionaliserings- } \\
\text { agenda voor nieuwe } \\
\text { arbeidsverhoudingen }\end{array}$ & $\begin{array}{l}\text { OCW / Stichting van } \\
\text { het Onderwijs }\end{array}$ \\
\hline $\begin{array}{l}\text { Techniekpact: } \\
\text { gezamenlijke aanpak } \\
\text { topsectoren }\end{array}$ & $\begin{array}{l}\text { Herschikking } \\
\text { onderzoeks-en } \\
\text { innovatiegelden; } \\
\text { investeringen in } \\
\text { PPS-constructies }\end{array}$ & $\begin{array}{l}\text { Vakbonden geen } \\
\text { partij in spel rond } \\
\text { innovatietrajecten } \\
\text { van grote onderne- } \\
\text { mingen met scholen }\end{array}$ & OCW / EZ / SZW \\
\hline $\begin{array}{l}\text { Zorgakkoord: } \\
\text { scherpe kantjes } \\
\text { afhalen van } \\
\text { bezuinigingen }\end{array}$ & $\begin{array}{l}\text { Inperking bezuini- } \\
\text { gingen, beperkte } \\
\text { loonstijging }\end{array}$ & $\begin{array}{l}\text { Strijd om wat kwali- } \\
\text { tatief hoogwaardige } \\
\text { zorg betekent }\end{array}$ & VWS \\
\hline $\begin{array}{l}\text { Woonakkoord: } \\
\text { aanpassing } \\
\text { hypotheekrente- } \\
\text { aftrek }\end{array}$ & $\begin{array}{l}\text { Afbouw van } \\
\text { hypotheekrenteaf- } \\
\text { trek, investeren in } \\
\text { subsidieregelingen }\end{array}$ & $\begin{array}{l}\text { Geslaagde lobby van } \\
\text { de bouwpartijen }\end{array}$ & VROM \\
\hline $\begin{array}{l}\text { Energieakkoord: } \\
\text { realiseren duurzaam- } \\
\text { heidsdoelstellingen }\end{array}$ & $\begin{array}{l}\text { Investeren in } \\
\text { PPS-constructies }\end{array}$ & $\begin{array}{l}\text { Onduidelijk, } \\
\text { mogelijk bijeffect: } \\
\text { nieuwe regulering } \\
\text { arbeidsverhoudingen }\end{array}$ & Commissie-Nijpels \\
\hline
\end{tabular}

achter de reeks van structurele hervormingen. Het Mondriaan-akkoord was een breed sociaal akkoord, maar anders dan de akkoorden uit de jaren 80 en 90 ging het hierbij vooral om een gedeelde agenda voor het domein van de arbeidsmarkt en de sociale zekerheid in de toekomst. De 'ad-hoc' domeinakkoorden die vervolgens tot stand zijn gekomen kunnen worden gezien als extra loten aan de stam van het Mondriaan-akkoord, waarbij het sociaal akkoord legitimiteit gaf aan de nieuwe werkwijze van onderhandelend bestuur in de Nederlandse polder. Cumulatief hebben 
het sociaal akkoord en de hier besproken domeinakkoorden niet alleen een de facto minderheidskabinet van breed maatschappelijk en politiek draagvlak voorzien; in meer programmatisch opzicht lijken de akkoorden stapsgewijs een fundamentele herijking van de Nederlandse politieke economie op te leveren, waarbij een aantal politieke taboes, waaronder de inperking van de hypotheekaftrek, de verhoging van de AOW-leeftijd en de herziening van de ontslagbescherming, politiek-maatschappelijk bespreekbaar en veranderbaar zijn gemaakt. Hiermee is de invulling van hervormingsambities tegelijk evenwichtiger en beter uitvoerbaar geworden, hetgeen ook weer ten goede is gekomen aan een versteviging van draagvlak. Deze nieuwe stijl van 'ad hoc' pragmatisch polderen komt niet uit de lucht vallen. Zij staat in een lange politieke Nederlandse traditie van het buitenparlementair delen van de beleidsruimte op het snijvlak van de parlementaire en maatschappelijke pijlers van onderhandelend bestuur en sociaal overleg. Een sterke overheid kan de verleiding moeilijk weerstaan om maatschappelijke actoren, maar ook lagere overheden (denk aan de grote decentralisatieoperaties in de maatschappelijke ondersteuning), in de eerste plaats te zien als uitvoeringsorganisaties van de Rijksdienst. Vanwege de status als minderheidsregering en de nakende sociale conflicten vanwege de enorme bezuinigingsverplichtingen in het kader van Europees budgettair beleid, was geen plaats voor politieke arrogantie. De aanhoudende crisis noopte de regering-Rutte-Asscher actoren in de maatschappelijke en politieke pijlers die niet gebonden waren aan de coalitie, te benaderen als potentiële broedplaatsen van programmatische aanpassingen in de hervormingsagenda. Zo maakte een politieke zwakte plaats voor bestuurlijke vernieuwing, waarbij inhoudelijke oplossingen die eerder niet aanvaardbaar leken, nu acceptabel werden gemaakt. Het is niet overdreven om te stellen dat zonder de akkoorden het kabinet-Rutte II hoogstwaarschijnlijk in een vroeg stadium ten val zou zijn gebracht.

Er is veel variatie naar inhoud, vorm, betrokken belanghebbenden en timing en tijdshorizon van de hier besproken akkoorden. Bij het zorgakkoord zocht de regering brede steun bij alle werkgevers en werknemersorganisaties in de zorgsectoren, alvorens het akkoord in het parlement te verkopen. Het woonakkoord is uit financiële nood geboren, maar de hete aardappel van de hypotheekrenteaftrek is door maatschappelijke partijen in een lang voortraject van tafel gehaald. Bij het techniekpact gaat het om investeringen op terreinen waarvoor door de crisis niet voldoende geld beschikbaar was. Uit publieke armoede deed de regering hier een beroep op maatschappelijke organisaties om publiek-private samenwerkingen mogelijk te maken in de kennis- en innovatieagenda. Bij het energieakkoord liet de SER van zich 
spreken als forum voor maatschappelijke vraagarticulatie en beleidssuggesties op het terrein van de herwaardering van het langetermijnbelang van een duurzaam leefmilieu.

De dans om de handtekeningen met veel heterogene partijen bij de verschillende akkoorden geeft een rommelig beeld, maar zodra een akkoord is ondertekend volgt in veel gevallen zorgvuldige monitoring om de progressie te staven: zitten we op het juiste tijdpad; is er ruimte voor of noodzaak tot intensivering of is een pas-op-de-plaats geboden? In de nieuwe constellatie van pragmatisch polderen is consensus in termen van inputlegitimiteit niet langer afdoende. In tegendeel, in een gedifferentieerde samenleving doen er meer partijen mee en moeten de resultaten - outputlegitimiteit - tastbaar worden gemaakt. Omdat de partijen achter de handtekeningen elkaar moeten kunnen aanspreken op resultaat en inspanning, is het beter om throughput voortgangsbewaking niet aan het Rijk over te laten, maar gezamenlijk te beleggen bij instellingen zoals DNB (pensioenen) of specifieke commissies (vgl. commissie-Nijpels bij het energieakkoord).

In een cumulatief proces van lerend monitoren (Sabel, 1994) doemen zeer waarschijnlijk nieuwe verdelingsvraagstukken op, die politiek moeten worden gewogen, en die met name van de winnaars vragen om ook rekening te houden met de verliezers, die met een geratificeerd akkoord niet zomaar van het toneel zijn verdwenen.

Het nieuwe polderen levert echter niet direct een stabiel institutioneel evenwicht op. Daarvoor zijn de economische condities en de maatschappelijk-politieke omgeving waarin het nieuwe polderen gestalte heeft gekregen te volatiel. Een van de belangrijke drijfveren achter het Mondriaan-akkoord was de verbetering of normalisering in de arbeidsverhoudingen en het overlegklimaat. Na de kater van het pensioenakkoord leken de werkgevers, en met name VNO-NCW-voorzitter Bernard Wientjes, zich te hebben gerealiseerd dat sociale conflicten politieke instabiliteit bevorderen. Het akkoord van 2013 hielp niet alleen Ton Heerts als voorzitter van de nieuwe FNV in het zadel, maar stelde het kabinet bovendien in staat een aantal sociaaleconomische hervormingen door te voeren die gezien zijn minderheidsstatus moeilijk tot stand waren gekomen. Maar de verhoudingen in de Nederlandse polder zijn niet echt verbeterd en gestabiliseerd. Hoge werkloosheid, miljardenbezuinigingen en gebrek aan publieke investeringen zijn niet in het voordeel van de vakbeweging gebleken, die intern nog steeds verdeeld is tussen de 'organizers' en de 'polderaars'. Het intrekken van de handtekening in het onderwijs- en zorgakkoord (en de nog lopende onderhandelingen over het 'loonakkoord') illustreert de problemen van de FNV in het publieke domein. In de marktsector zijn de vakorganisaties in 
een aantal sectoren zo zwak geworden dat ze de hulp van de politiek hard nodig hebben in de strijd tegen lage beloningen en flexibilisering van de arbeid. Ook op het cao-front blijft het overlegklimaat guur en onrustig. En ondertussen etaleert de nieuwe werkgeversvoorzitter Hans de Boer een steeds duidelijker afkeer van de Nederlandse polderinstituties, waarmee de arbeidsverhoudingen opnieuw op scherp komen te staan.

Maar niet alleen de maatschappelijke pijler is verzwakt, ook de politiek pijler van onderhandelend bestuur is kwetsbaar. In de politieke pijler van onderhandelend bestuur is gebleken dat zelfs senatoren van coalitiepartijen in de Eerste Kamer zich niet altijd konden vinden in de akkoorden, waardoor op het laatste moment belangwekkende wijzigingen in hervormingen moesten worden aangebracht, zoals bij het zorgbeleid en het woondossier. De verdere versplintering van het politieke midden vormt een duidelijk politiek risico voor het nieuwe pragmatische polderen. Opvallend is dat de regeringspartijen veel minder dan in de tachtig en negentig, toen de kabinetten-Lubbers en -Kok na impopulaire ingrepen werden herkozen, politiek garen weten te spinnen bij de nieuwe successen in de Nederlandse polder. Vooral coalitiepartner PvdA is nauwelijks in staat gebleken om politiek krediet te claimen voor de responsieve hervormingsstrategie van het kabinet, waarbij het de vakbeweging is kwijtgeraakt aan de linkse oppositie.

Voorlopig lijken partijen in het politieke midden elkaar vaker op te (moeten) zoeken. Er is brede steun van GroenLinks, PvdA, D66, de ChristenUnie, CDA, VVD en de SGP voor het door de EU afgedwongen stringente budgettaire beleid, in weerwil van EU-scepsis op de politieke flanken. Dankzij deze breed geaccepteerde Europese randvoorwaarden, een niet al te dichtgemetseld regeerakkoord en de open uitnodiging aan maatschappelijke spelers om mee te denken over langetermijnhervormingen, is het kabinet-Rutte-Asscher succesvol gebleken in beleid en politiek. Maar de centrifugale krachten van politiek populisme en maatschappelijke confrontatie zijn niet te miskennen. Er is sprake van een fragiel evenwicht, maar een reëel alternatief voor de facto centrum-minderheidskabinetten, die maatschappelijke belangen een belangwekkende rol toebedelen in de beleidsontwikkeling, heeft zich nog niet aangediend. 



\title{
8 De invloed van het sociaal akkoord op de Nederlandse arbeidswetgeving
}

\author{
Klara Boonstra
}

Op 3 april 1996 stuurden de sociale partners bij monde van de Stichting van de Arbeid de nota 'Flexibiliteit en Zekerheid' naar toenmalig minister van SZW Melkert - van PvdA-huize in een paars kabinet. Zeventien jaar later, op 11 april 2013, ontving minister Asscher, óók PvdA en óók paars, van dezelfde afzender het 'Perspectief voor een sociaal én ondernemend land: uit de crisis, met goed werk, op weg naar 2020; verantwoordelijkheid nemen én dragen, kansen creëren én benutten'. Beide akkoorden hebben tot wetgeving geleid waarin de inhoud van het akkoord goed terug is te vinden, hoewel ook weer niet kan worden gesteld dat de wetgeving die eruit voortkwam een een-op-eenregeling is van wat de sociale partners voorstelden. In dit hoofdstuk worden de ontwikkelingen die betrekking hebben op de arbeidsverhoudingen in de betreffende periode van een kleine twintig jaar onder de loep genomen, en wordt onderzocht in hoeverre de twee sociale akkoorden effectief zijn geweest in het oplossen van de problemen op de arbeidsmarkt, die de sociale partners zagen als de reden om de akkoorden af te sluiten. Onderzocht wordt welke plek deze centrale akkoorden eigenlijk innemen in het sociaalrechtelijk bestel: het weefsel van wetten, cao-recht en individueel arbeidsrecht dat de dijken van de polder ondersteunt of misschien zelfs wel vormt. Welke arbeidsmarktpartijen doen eraan mee en hoe werken zijzelf en degenen die zij vertegenwoordigen mee aan de uitvoering in de overeenkomsten die voortvloeien uit de wetgeving? Maar ook: welke partijen onttrekken zich eraan of worden buiten het systeem gehouden, en heeft dat een effect op de stevigheid van de polder? Het sluitstuk is het sociaal akkoord van 2013 en de verschillende wetgevingsprocessen die daarop zijn gevolgd en nog gaande zijn. ${ }^{1}$ De vraag is of in deze ronde van 2013 oplossingen zijn gevonden voor de mogelijke mislukking van 1996, of dat men wellicht hier en daar in dezelfde val is gelopen.

Dit hoofdstuk gaat over de juridische vormgeving van arbeidsrelaties en de manier waarop de sociale partners door middel van sociale akkoorden die vormgeving trachten aan te passen aan ontwikkelingen op de arbeidsmarkt. Voor een deel zijn die ontwikkelingen nationaal van aard. 
Dat levert een soort droste-effect op, omdat ze er zelf deels voor verantwoordelijk zijn. Hun achterban, die bestaat uit de individuele werkgevers en werknemers, bepaalt immers de inhoud van de arbeidsovereenkomsten en cao's. Met de sociale akkoorden beogen de centrale sociale partners in feite ook hun eigen achterbannen in het gareel te brengen. Omdat zij daartoe geen rechtstreekse juridische middelen hebben, vragen zij de wetgever om hun daarbij behulpzaam te zijn. Een groot deel van de ontwikkelingen en invloeden is echter niet nationaal van aard maar Europees of mondiaal. Denk aan het EU vrij verkeer van werknemers en diensten binnen de EU en de globalisering van de handel. In dat geval hebben de sociale partners de wetgever nodig om te garanderen dat ook de buitenlandse werkgevers zich aan het Nederlandse arbeidsrecht moeten houden. Steeds meer moet het Nederlandse overlegmodel, dat voorheen Nederlandse zaken regelde, de polder beschermen tegen krachtige golven van buiten.

\section{Het Nederlandse overlegmodel en de vormgeving van arbeidsrelaties}

Visser en Hemerijck concluderen in 1997 optimistisch dat het Nederlandse overlegmodel aantoont dat modernisering van de Europese welvaartsstaat mogelijk is (Visser en Hemerijck, 1997, p. 179). Die conclusie lijkt echter vooral te slaan op het effectief terugdringen van het beroep op socialezekerheidsregelingen en het creëren van 'werk, werk en nog eens werk', het motto van het kabinet-Kok I van 1994-98. Maar wat zijn dat voor banen? Ten tijde van het schrijven van het boek van Visser en Hemerijck waren de flexibele arbeidsrelaties zeker al in opmars en één variant daarvan, deeltijdwerk, wordt terecht als een van de motoren van modernisering beschouwd (ibid., p. 180). Inderdaad kampen wij veel minder dan andere landen met een slechte kwaliteit van deeltijdbanen. Daarbij hoort echter wel een kanttekening. In eerste instantie, vanaf de jaren 80, werd vooral de toetreding van Nederlandse vrouwen op de arbeidsmarkt door middel van de mogelijkheid om in deeltijd te werken gefaciliteerd (CBS, 2012, p. 20). Dat leidde in vergelijking met andere landen toen tot een relatieve hoge kwaliteit van deeltijdbanen. De latere combinatie van deeltijdwerk met tijdelijk werk, uitzendwerk en schijnzelfstandigheid aan de onderkant van de arbeidsmarkt, leidde er echter toe dat ook deeltijdwerk een onderdeel werd van het probleem van doorgeschoten flexibilisering, een term die wordt gebruikt in het sociaal akkoord van 2013 (StvdA, 2013, p. 2). Hetzelfde geldt voor uitzendwerk. Waar dat in andere landen nogal eens van inferieure 
kwaliteit is in vergelijking met de rest van de arbeidsmarkt, werd het in Nederland vaak gezien als onderdeel van de high road to flexibility. De snelle ontwikkeling van de dienstensector, waarin veel uitzendwerk wordt gebruikt, werd eind jaren 90 genoemd als banenmotor, een ontwikkeling die zich na de eeuwwisseling explosief heeft doorgezet. De vraag is echter gerechtvaardigd of dat positieve predicaat ook mag worden geplakt op arbeidscontracten van obscure uitzendbureautjes, vaak gevestigd in de MOE-landen, die hun werknemers hier aan de onderkant van de arbeidsmarkt tewerkstellen. Het arbeidsrecht kent verschillende doelen, maar het voornaamste doel is toch wel de bescherming van de werknemer tegen de veel grotere economische macht van zijn werkgever. Het is onmiskenbaar dat de afgelopen jaren worden gekenmerkt door de opmars van kwalitatief mindere flexibele arbeidsrelaties. ${ }^{2}$ We zien vooral de toename van tijdelijke arbeidsovereenkomsten (Houwing, 2010, p. 146), maar ook allerlei vormen van driehoeksrelaties zoals uitzenden en contracting. Bovendien hebben de zelfstandigen-zonder-personeel massaal de markt betreden, van wie een aantal zeer kwetsbaar is vanwege het lage inkomen en het gebrek aan voorzieningen voor risico's in verband met de arbeid, zoals gebrek aan werk en arbeidsongeschiktheid. ${ }^{3}$ Het centrale kenmerk van al die arbeidsrelaties is dat de continuïteit van het werk en daarmee het inkomen steeds minder gegarandeerd is.

Het optimisme van 1996 was vanwege deze latere ontwikkelingen misschien niet helemaal gerechtvaardigd, zo moeten we constateren wanneer het sociaal akkoord van 2013 stelt:

2 Sinds eind 2008 is het aantal werknemers met een vaste arbeidsrelatie met bijna 600 duizend geslonken. In de loop van 2014 kwam deze daling tot stilstand. Het aantal vaste werknemers bedroeg in het tweede kwartaal van 2015 ruim 5 miljoen. Dat waren er 28 duizend minder dan een jaar eerder. Het verschil ten opzichte van het jaar ervoor wordt steeds kleiner. In het tweede kwartaal van 2015 waren er bijna 1,9 miljoen werknemers met een flexibele arbeidsrelatie, 100 duizend meer dan een jaar eerder. Het aantal werknemers met een flexibel contract neemt al sinds medio 2010 toe. De groei komt vooral voor rekening van uitzendkrachten. Het aantal flexwerkers hangt samen met de conjuncturele ontwikkeling. Werknemers met een flexibel contract zijn vaak degenen die schommelingen moeten opvangen in de vraag naar goederen en diensten. Ook het aantal zelfstandigen neemt toe. In het tweede kwartaal 2015 waren er bijna 1,4 miljoen zelfstandigen, 32 duizend meer dan een jaar eerder. Sinds 2008 ligt dit aantal in elk kwartaal hoger dan in hetzelfde kwartaal in het voorgaande jaar. De toename is in belangrijke mate toe te schrijven aan de zelfstandigen zonder personeel. Bron http://www.cbs.nl/nl-NL/ menu/themas/arbeid-sociale-zekerheid/publicaties/arbeidsmarkt-vogelvlucht/korte-termijnontw/vv-positie-werkkring-arbeidsduur-art.htm.

3 Het Financieele Dagblad 12-11-2014. 
Het huidige complex aan arbeidscontracten en gerelateerde wetgeving leidt in de praktijk op onderdelen, tot steeds meer ontsporingen en levert in toenemende mate voor de economie als geheel suboptimale resultaten op. Zo wordt steeds meer gebruik gemaakt van (schijn)constructies die enkel dienen om collectieve afspraken en regelgeving te omzeilen. Er is in toenemende mate sprake van doorgeschoten flex (StvdA, 2013, p. 2).

Dit citaat is bijzonder en zal in dit hoofdstuk nog een aantal keer worden aangehaald omdat dit een gezamenlijke uitspraak is van werkgevers én werknemers. Wellicht deels ingegeven door de gevolgen van de economische crisis van de afgelopen jaren, maar dan toch binnen een arbeidsrechtelijke ordening die na het vorige sociaal akkoord van 1996 is ontwikkeld en blijkbaar toch niet voor voldoende kwalitatieve banen heeft kunnen zorgen. Het 'werk, werk en nog eens werk's is blijkbaar niet van zodanige kwaliteit dat een nieuwe hervormingsronde na een kleine twintig jaar niet nodig is. Voldoet het instrumentarium van het Nederlandse polderoverlegmodel nog wel om de toenemende problematiek van de 'doorgeschoten flex' tegemoet te treden?

\section{De rol van de sociale partners in het staatsbestel}

Met enige regelmaat, eerst in 1982 met het Akkoord van Wassenaar en meer recent in 1996 en 2013, vinden de sociale partners die zijn verenigd in de Stichting van de Arbeid $^{5}$ elkaar in een gezamenlijke centrale agenda, die aan de politiek wordt aangeboden om vervolgens het sociaaleconomisch beleid en wetgeving vorm te geven. Waarom juist op die momenten? Moeten de tussenliggende perioden worden beschouwd als perioden van consensus waarin het sociaaleconomische leven rustig voortkabbelt, of juist als tijden van conflict die consensus of zelfs maar compromis in de weg staan? Onder welke voorwaarden doet de wetgever mee, en betreft dat vooral de regering of is ook het parlement loyaal aan het proces?

Elk sociaal akkoord kan uiteraard worden beschouwd als een moment waarop consensus bestond ten aanzien van een aantal onderwerpen, maar het kan ook geen kwaad om te onderscheiden dat het tegelijkertijd een overeenkomst 'to agree to disagree' is. Werkgevers en hun organisaties aan de ene kant en vakbonden aan de andere, zijn eraan gewend om recht 
tegenover elkaar te staan en toch tot overeenkomsten te komen. Ze weten dat ze toch altijd weer met elkaar verder moeten en onder die druk komen compromissen tot stand. Wat dat betreft onderscheidt een centraal sociaal akkoord zich niet principieel van een individuele of collectieve arbeidsovereenkomst. Dat is uiteraard wel het geval wat betreft de reikwijdte van de verbindendheid. Een akkoord is geen overeenkomst. Normaal gesproken bindt een overeenkomst alleen de partijen, maar bij een sociaal akkoord hebben de partijen het oogmerk de inhoud van hun overeenkomst te laten gelden voor de hele samenleving. Ze bepleiten als het ware dat hun gezamenlijke belangen samenvallen met het algemeen belang. In Nederland is dat in tegenstelling tot de meeste andere landen op zich niet zo bijzonder. Onze arbeidswetgeving laat zien dat die uitbreiding door de overheid van de dekkingsgraad van de overeenkomsten tussen sociale partners al een kleine honderd jaar in ons recht is verankerd door middel van de Wet op het algemeen verbindend verklaren van cao's. Die wet bepaalt dat de partijen in een sector hun cao voor algemeenverbindendverklaring (avv) kunnen voordragen aan de minister van Sociale Zaken en Werkgelegenheid. Deze heeft de bevoegdheid om tot avv over te gaan, mits is voldaan aan een aantal voorwaarden, die te vinden zijn in de wet zelf en de bijbehorende regelgeving. ${ }^{6}$ De belangrijkste voorwaarde is dat de cao al voor een belangrijke meerderheid in de betreffende sector geldt. Op het eerste gezicht lijkt dit een eenvoudige numerieke eis van representativiteit te zijn. Dat is ook het geval, maar op een andere, meer ingenieuze wijze dan op het eerst gezicht lijkt. De cao (althans alle cao's tezamen) geldt in Nederland voor 80 procent van de werknemers, terwijl zo rond de 22 procent van hen lid is van een vakbond. Aan werkgeverszijde is de organisatiegraad hoog, zo'n 80 procent. ${ }^{7}$ Voor welke betrokkenen geldt de cao op grond van de overeenkomst? Uiteraard voor de contractpartijen: de sectorale werkgeversorganisatie en de daarbij aangesloten leden, en de vakbond en zijn leden. In sommige sectoren die met een hoge organisatiegraad aan werknemerszijde van meer dan $5^{0}$ procent - zullen die al een meerderheid vertegenwoordigen. Maar we weten dat er niet zoveel sectoren zijn waar de organisatiegraad zo hoog is, en toch worden de meeste cao's wel ge-avv'd. Dat komt omdat voor het bepalen van de meerderheid het aantal werknemers moet worden opgeteld dat bij alle aan de cao gebonden werkgevers in dienst is. Een voorbeeld ter verduidelijking: als in een sector waar tien werkgevers actief zijn bij drie van

6 Toetsingskader Algemeen Verbindend Verklaring Cao-bepalingen (AVV).

7 Voor actuele gegevens zie:http://www.cbs.nl/nl-NL/menu/themas/arbeid-sociale-zekerheid/ publicaties/artikelen/archief/2014/2014-4153-ta.htm. 
die werkgevers 60 procent van de werknemers in die sector werkzaam zijn, dan is sprake van een belangrijke meerderheid in de zin van de wet. Daarbij maakt het dus niet uit of dat vakbondsleden zijn of niet. De werkgever die is gebonden op grond van de cao, is verplicht om de arbeidsvoorwaarden van die cao toe te passen op al zijn werknemers. In die zin is het logisch om hen ook mee te tellen voor het 'gelden' van de cao. De minister toetst door middel van dit systeem aan de zijde van de werknemers niet zozeer hoeveel van hen zich door het lidmaatschap hebben verbonden, maar voor welk deel van de werknemers het pakket van arbeidsvoorwaarden geldt. Dat is dan voor die sector het level playing field, dat vervolgens van overheidswege wordt vastgelegd voor de duur van de cao. Zo zijn er sectoren waar het vakbondslidmaatschap maar een paar procent is en toch het niveau van de arbeidsvoorwaarden van de cao als bodem functioneert.

Het systeem maakt dat een afspraak tussen burgerlijke partijen, een in dit geval privaatrechtelijke collectieve overeenkomst, door een overheidsdaad voor een bepaalde periode wordt verheven tot een wettelijke norm. ${ }^{8}$ Het aanvaarden van een sociaal akkoord door de overheid als eigen beleidsdoelstelling is in feite een vergelijkbare vorm. Het belang van de sociale partners achter uitbreiding van de werking van de instrumenten is duidelijk: wie zou niet willen dat iedereen zich aan dezelfde normen moet houden als hijzelf? Maar waarom gaat onze overheid daarin mee? Dit cao/ avv-systeem vormt de juridische basis van de arbeidsmarktordening en is een belangrijk instrument om onderbieding tegen te gaan. In die zin heeft het voor jarenlange arbeidsrust gezorgd en een stevige sociaal rechtvaardige bodem wat betreft lonen, arbeidstijden en andere arbeidsvoorwaarden gelegd. Visser en Hemerijck (1997, p. 183) stellen bovendien terecht dat staten vrijwel nooit in de positie zijn functioneel georganiseerde belangengroepen te vertellen wat ze moeten doen of laten. Als wetgeving niet door de gebruikers wordt gedragen zullen ze het simpelweg niet toepassen. De doelstellingen van de wet- of beleidsmakers zullen dan niet worden behaald. Dat is in zijn algemeenheid het geval en geldt voor de goed georganiseerde sociale partners des te sterker. Daarin ligt de kern van deze constructie; de overheid en het georganiseerde bedrijfsleven delen de verantwoordelijkheid voor sociaal rechtvaardige arbeidsvoorwaarden en -omstandigheden in een beweeglijk normatief systeem.

Werkgevers en werknemers interacteren op individueel, ondernemings-, sector- en nationaal niveau door middel van het sluiten van individuele en collectieve overeenkomsten over de arbeidsvoorwaarden, die in beginsel 
slechts voor henzelf gelden. Ook functioneren er zeer veel samenwerkingsorganen die op de eigen activiteiten zijn gericht, zoals $\mathrm{O} \& \mathrm{O}$ en pensioenfondsen. Anders dan wellicht weleens als indruk bestaat, zijn de activiteiten van zowel vakbonden als werkgevers en hun organisaties in eerste instantie vooral op elkaar en hun dagelijkse werkelijkheid van de werkplek gericht, en niet op de Haagse politiek en het bestuur. Cruciaal in onze arbeidsverhoudingen is echter wel degelijk de rol van de overheid als bestuurder inzake de ondersteuning en bestendiging van de overeenkomsten tussen werkgevers en werknemers. Al vroeg in de vorige eeuw heeft de Nederlandse wetgever gekozen voor een beperkte eigen rol in het vaststellen van het niveau van de arbeidsvoorwaarden. De arbeidswetgeving regelt weinig meer dan minimaal noodzakelijke standaarden met betrekking tot lonen, arbeidstijden en roosters, en vakantie en dergelijke. De feitelijke arbeidsvoorwaarden komen tot stand in het autonome proces van arbeidsvoorwaardenvorming, waarna de minister van SZW deze onder voorwaarden voor het hele bereik van de collectieve overeenkomst algemeen verbindend verklaart volgens het hierboven omschreven systeem (Loonstra, 1989). Hij bemoeit zich dus behalve door het minimum te bepalen niet met het feitelijke niveau. Door dit systeem van arbeidsvoorwaardenvorming kunnen de arbeidsvoorwaarden evolueren naar gelang de economische omstandigheden van een bepaald moment en zelfs in een bepaalde sector. De voor de betreffende arbeidsrelatie geldende lonen en andere arbeidsvoorwaarden zijn in de collectieve arbeidsovereenkomsten te vinden. Dat is anders dan in veel andere landen, die een meer op wetgeving gericht heteronoom stelsel kennen. Daar waar bijvoorbeeld in Frankrijk de arbeidstijd tot en met de overwerkvergoeding bij wet is bepaald, en dus als in steen gebeiteld staat, hebben wij een beweeglijk systeem van arbeidsvoorwaardenvorming. De overheid legt de basis maar erkent ook een staatsvrije ruimte, en ondersteunt daarmee direct het vrije proces van collectieve arbeidsvoorwaardenvorming. Het algemeen verbindend verklaren is een daad van materiële wetgeving waarbij de overheid zich onthoudt van bemoeienis met de inhoud van de afspraak, die blijkbaar door de werkgevers en werknemers in de betreffende sector passend wordt geacht.

Dit ordeningsprincipe heeft altijd de basis gevormd voor de rustige arbeidsverhoudingen van ons land, waarin de rollen over en weer worden erkend, maar elk van de deelnemers zijn inzet kan bepalen naar de omstandigheden van het moment. De wetgever kan best meer in de wet gaan regelen als hij dat wil, maar laat de materiële invulling over het algemeen graag over aan degenen die met de resultaten gaan werken. Hij delegeert als het ware de invulling aan de sociale partners en verzekert daarmee 
draagvlak voor zijn handelen. 'De daardoor gedeelde legitimiteitswaarden zijn in staat een gevoel van normatieve verplichting te creëren, dat helpt de vrijwillige naleving van ongewilde regelingen of besluiten van het heersende bestuur te garanderen. Omdat wordt voorzien in rechtvaardiging en sociale ondersteuning zullen zulke overtuigingen de noodzakelijkheid van controle en sanctionering, die anders noodzakelijk zouden zijn voor naleving, beperken' (Scharpf, 2009).

De visie op die rolverdeling van overheid en sociale partners is evenwel politiek niet per definitie een constante. Politieke partijen en stromingen hebben verschillende, nu weer eens een ideologische, dan weer eens praktische opvattingen over de rollen van de sociale partners. Coalities bevinden zich in verschillende perioden ideologisch dichter bij de werkgevers-, dan wel bij de vakbondskant. Van partijen die in de afgelopen twee decennia regeringsverantwoordelijkheid hebben gedragen was het vooral de VVD die de grote rol van de autonome arbeidsvoorwaardenvorming in de sociaaleconomische politiek door middel van algemeen verbindend verklaren van cao's nogal eens ter discussie stelde. Onlangs kwam daar ook incidenteel het CDA, en in de laatste jaren met name ook D66 bij. Het meer liberale politieke landschap dat daarmee ontstaat, legt de prioriteit meer bij de staat als waarborgschepper van individualistische rechten, dan bij de erkenning van de collectiviteiten, die de basis vormen van het 'poldermodel'. Dat ligt anders als partijen een coalitie vormen die de solidariteit, dan wel voorheen de soevereiniteit, in eigen kring of tegenwoordig het maatschappelijk middenveld hoog in het vaandel draagt. De Partij van de Arbeid en het CDA zijn, c.q. waren, van oudsher partijen die nauw en op ideologie gelieerd zijn aan collectiviteiten zoals vakbonden en consumentenorganisaties in de samenleving, en daar ook een deel van hun macht aan ontlenen. We mogen aannemen dat ook de SP en in mindere mate GroenLinks zich meer aan deze kant bevinden (zie ook Hemerijck en Van der Meer in deze bundel).

De opportuniteit van een sociaal akkoord hangt sterk af van de politieke constellatie op een bepaald moment. Is er een coalitie die als liberaal is te beschouwen, dan hebben werkgevers meer te winnen bij het eenzijdig zonder vakbonden benaderen van de politiek. Is daarentegen een regering aan de macht die solidariteit en draagvlak hoog in het vaandel heeft, dan kunnen in beginsel de vakbonden de weg naar beïnvloeding van beleid makkelijk zonder werkgevers vinden. Andersom geldt dat voor politieke partijen waarschijnlijk ook. Wordt een coalitie gedragen door een uniforme achterban, dan heeft zij het niet nodig extra draagvlak uit de samenleving te halen. Moet een coalitie (Paars!) echter in haar beleid heterogene belangen verenigen, dan moet zij het draagvlak in de samenleving veiligstellen. Vanuit 
deze blik is de ontwikkeling van een sociaal akkoord dat door de regering als sociale agenda wordt aanvaard eigenlijk een evenwichtskunstje in een situatie van disbalans.

\section{Legitimiteit en representativiteit in het kader van het algemeen en het eigen belang}

Er bestaat, zo zagen wij hierboven, een arbeidsrechtelijk aanknopingspunt om vast te stellen wat althans de wetgever beschouwt als een noodzakelijke achterban van werkgevers en vakbonden om het bereik van overeenkomsten groter te laten zijn dan alleen degenen die lid zijn van de vereniging. Dat in veel gevallen een flink deel van de werknemers een zogenaamde 'freerider' is, dat wil zeggen geen lid is van de vakbond, is niet verrassend; het individuele nut is gelijk, of er nu contributie wordt betaald of niet. Representativiteit als vereiste voor de toepassing van arbeidsvoorwaardenregelingen wordt dus niet vastgesteld door middel van een numerieke benadering aan vakbondskant, maar aan het bereik dat gebonden werkgevers aan het instrumentarium geven.

Deze kwalitatieve representativiteit vormt indirect ook het draagvlak voor de vertegenwoordiging op centraal nationaal niveau, waar de contacten met de overheid zich afspelen. Dat is het niveau van de sociale akkoorden, de SER en de Stichting van de Arbeid. Datgene wat door de sociale partners niet op het decentrale niveau met elkaar door middel van het arbeidsrechtelijke instrumentarium kan worden geregeld, wordt op grond van een logisch gegroeid subsidiariteitsbeginsel naar het nationale niveau getild op het moment wanneer dat sociaal-politiek opportuun is. De sociale partners moeten zich er bij die stap uiteraard van bewust zijn dat ze zich bij de bepaling van hun inzet niet slechts op het eigen (leden)belang kunnen richten. Ze betreden het domein van het algemeen belang. Van vakbonden wordt bijvoorbeeld verwacht dat ze staan voor de belangen van de zwakkeren in de samenleving, werkend of niet. Of juist tegelijkertijd vooral voor de belangen van álle werkenden, zelfstandig of in dienst. Werkgeversorganisaties moeten tonen dat ze alle ondernemers kunnen vertegenwoordigen, van de zzp'er en de bloemenman op de hoek tot de multinationals in de internationale concurrentieverhoudingen. Beiden moeten er voor waken te worden beschouwd als een partij die alleen de belangen behartigt van de 'insiders', oftewel hun leden en ook de 'free-riders' die meeprofiteren van het systeem, zonder rekening te houden met de 'outsiders'. Dat zijn ze ten opzichte van elkaar echter gewend, omdat ze van oudsher ook in 
de Stichting van de Arbeid en de SER op dit niveau opereren. Die houding verschilt niet principieel van hetgeen zij in de cao doen: naast de belangen van de leden evenzeer die van niet-leden en vooral werkenden met een zwakkere positie in de onderneming of de sector behartigen. Als op het moment dat de sociale partners elkaar vinden ook de overheid ontvankelijk is, omdat de dan regerende coalitie moeite heeft zelf het draagvlak van het gekozen beleid overduidelijk waar te maken, dan ontstaat de juiste dynamiek voor een sociaal akkoord. Ten tijde van 'het Nederlandse mirakel' in 1996 was daar onder Paars I sprake van, en opnieuw in 2013 (ook Paars, maar de eerste jaren tot zomer 2015 zonder mirakel) na een politiek extreem onrustige periode van vijf kabinetten in tien jaren en in de nasleep van een ernstige economische crisis.

Het vaak gehoorde bezwaar tegen de gang van zaken waarin een kabinet direct zaken doet met niet-parlementaire actoren, is dat dit een niet-transparant proces is en dat de actoren geen verantwoording aan de bevolking hoeven af te leggen, zoals dat wel in het parlementaire proces vereist is. Termen als neocorporatisme vallen, waarbij de representativiteit van met name de vakbonden wordt betwist in het licht van de relatieve daling van het aantal vakbondsleden ten opzichte van de groeiende beroepsbevolking. Er zou sprake zijn van een black box en achterkamertjespolitiek. Wellicht was daar ten tijde van de verzuiling sprake van, maar die tijd ligt toch wel ver achter ons. In de huidige tijd zijn weinig actoren in hun inzet zo transparant als werkgevers en werknemers. En als ze het zelf niet zijn, dan dwingen de media ze wel tot openheid. Het glazen huis waarin ze moeten opereren om verschillen in opvatting te overbruggen teneinde tot een akkoord te komen en de steun voor de implementatie ervan te verkrijgen, biedt een adequater beeld dan de blackbox. Dat wil echter niet zeggen dat het proces omtrent een sociaal akkoord ontspannen is. De crisis over het pensioen bij de FNV in 2012 en het voortijdig opstappen een jaar later van MKBvoorzitter Biesheuvel laten zien dat veel spanning kan ontstaan als de leden die de nauwe achterban vormen vinden dat de leiders te ver voor de troepen uitlopen. De spanningen ten opzichte van hun eigen achterbannen om niet te veel weg te geven en toch ruimte te behouden om te manoeuvreren kunnen makkelijk oplopen. Dat wordt versterkt als permanent nadruk wordt gelegd op nominale representativiteit door actoren die zich buitengesloten of onvoldoende betrokken voelen. Dat kan bijvoorbeeld het geval zijn voor het parlement, dat vindt dat de regering haar oren te veel laat hangen naar buitenparlementaire partijen zoals de sociale partners. Het is begrijpelijk dat parlementariërs zich in de wiek geschoten voelen als niet hun opvatting over maatschappelijke vraagstukken leidend is voor het proces, maar de 
regering zijn input elders gaat halen. Wanneer vervolgens het parlement alleen maar ja of nee mag zeggen tegen dichtgetimmerde pakketten, loopt die Haagse onvrede nog op. Ook logisch. De sociale partners kunnen daar echter in staatsrechtelijke zin niet verantwoordelijk voor worden gesteld. Het parlement en zijn leden beschikken bovendien over parlementaire middelen om daarop invloed uit te oefenen.

\section{Gaten in de dijken rondom de polder}

Het hierboven beschreven systeem waarin de arbeidsrechtelijke representativiteit als basis geldt voor nationale sociale verhoudingen is niet onfeilbaar. Het kent mazen en werkt ook binnen de nationale verhoudingen niet altijd optimaal. Zo moet er uiteraard eerst een cao tot stand komen voordat deze algemeen verbindend kan worden verklaard. Tegen avv kunnen bezwaren worden ingebracht door partijen die van mening zijn dat de avv niet voor hen zou moeten gelden, en ook kan onder bepaalde voorwaarden dispensatie van de avv worden verleend. Als in een bepaalde sector de onderhandelingen stroef verlopen ontstaan er, soms lange, cao-loze en dus avv-loze perioden. Op dat moment is het echter voor de cao-partijen over het algemeen niet mogelijk om onder het minimum van de vorige cao te gaan zitten wat betreft de arbeidsvoorwaarden. De cao heeft namelijk juridische nawerking, waardoor de partijen ook na expiratie van de cao vanwege doorwerking ervan in hun individuele overeenkomst aan het niveau van de cao blijven gebonden. Dat geldt echter niet voor werkgevers die op grond van avv aan de cao gebonden werden. Voor hen herleeft de contractsvrijheid en zij kunnen dus de ruimte tussen het minimumniveau van de wet en dat van de cao gaan benutten. We zien steeds vaker dat in die perioden cao's tot stand komen met maar een deel van de vakbonden of met vakbonden die niet vertegenwoordigd zijn in het centrale overleg. Datzelfde geldt voor ondernemers die vanuit andere EU-landen hun diensten aanbieden. De wet bepaalt weliswaar dat ook zij een kern van algemeen verbindend verklaarde arbeidsvoorwaarden moeten toepassen ${ }^{9}$, maar toezicht op de naleving daarvan is zeer problematisch. De overheidsinstanties handhaven namelijk over het algemeen alleen maar de wettelijke minimumbepalingen zoals het minimumloon en de arbeidstijden. Dat vloeit voort uit het systeem dat hiervoor werd besproken. Op het moment dat het afsluiten van cao's

9 De Wet arbeidsvoorwaarden grensoverschrijdende arbeid (WAGA), implementatie van de Detacheringsrichtlijn 96/71/EG. 
moeizaam gaat en er partijen actief worden op de arbeidsmarkt die tegen een lagere prijs kunnen produceren omdat de arbeidskosten lager zijn, kan ook voor de werkgevers die wel deel uitmaken van de institutionele verhoudingen de druk groter worden om zich aan het systeem te onttrekken. Het level playing field gaat dan rafelen en gaten vertonen.

De kracht van het systeem wordt ook niet alleen door de insiders ervan bepaald, maar ook door externe factoren en invloeden. Buitenlandse ondernemers en toetreders op de arbeidsmarkt die op grond van het EUrecht hun arbeid mogen aanbieden op de Nederlandse arbeidsmarkt maken bijvoorbeeld geen deel uit van dit systeem. Maar ook binnen de nationale context kunnen partijen die zich buiten het systeem gesloten achten zich manifesteren. Niet alle Nederlandse vakbonden zijn in de Stichting van de Arbeid georganiseerd. Nieuwkomers als Alternatief voor Vakbond (AVV) en de Landelijke Belangenvereniging (LBV), die niet bij de vakbondscentrales zijn aangesloten, klagen dat de gevestigde orde van de Nederlandse arbeidsverhoudingen hen buitensluiten. Ook zij kunnen zich als contractpartij aanbieden, de numerieke representativiteit is immers daarvoor geen voorwaarde.

Op momenten waarop dus enerzijds sprake is van een coalitie die heterogene belangen vertegenwoordigt en anderzijds de sociale partners zelf met hun eigen instrumentarium niet in staat zijn om bepaalde problemen te regelen waarmee zij worden geconfronteerd, lijkt de prikkel te ontstaan om door middel van een sociaal akkoord tot wet- en regelgeving te komen. De heterogeniteit van paarse coalities, zeker op sociaaleconomisch vlak, is eigenlijk een vanzelfsprekendheid. In 2013 is daar nog een zwakke positie in de Eerste Kamer bij gekomen. Maar wat lukte de sociale partners niet zelf in 1996 en waarom moest die exercitie weer over in 2013?

\section{Eind jaren 9o; creatie van de paradox 'flexicurity'}

In 1996 schreef de Stichting van de Arbeid de nota 'Flexibiliteit en Zekerheid' als reactie op een verzoek van toenmalig minister Melkert om hem te adviseren over een aantal aspecten met betrekking tot de flexibilisering van het arbeidsbestel (StvdA, 1996). Hij verzocht overigens geenszins een integrale visie op de ordening van de arbeidsmarkt. Maar die kreeg hij wel van de Stichting van de Arbeid, een teken dat de sociale partners zo hun eigen agenda hadden. De onderwerpen van het verzoek liepen nogal uiteen en waren vooral van juridisch-technische aard. Het betrof de proeftijd; de loondoorbetalingsverplichting wanneer er geen werk is; en ook voorstellen 
die gericht waren op het bieden van meer ruimte voor verlenging van kortdurende tijdelijke contracten enerzijds en minder ruimte voor repeterend gebruik van langdurige tijdelijke contracten anderzijds. Verder vroeg hij om input voor een regeling voor uitzendbureaus.

Welke doelen konden de sociale partners, indachtig hetgeen hiervoor is gesteld, niet zelf met hun eigen instrumentarium verwezenlijken op dat moment? Op het moment van de adviesaanvraag had een aantal belangrijke ontwikkelingen plaatsgevonden op de arbeidsmarkt. Het gebruik van voor de werknemers slechte vormen van flexibele arbeid had in betrekkelijk korte tijd een hoge vlucht genomen. In 1991 wees de Hoge Raad het Campina-arrest ${ }^{10}$ en in 1994 het Agfa-arrest. ${ }^{11}$ Beide arresten worden als een mijlpaal gezien in de kentering op de arbeidsmarkt van vaste contracten naar tijdelijke contracten, vaak in lange ketens aaneen. In het Campinaarrest oordeelde de Hoge Raad over de draaideurconstructie, waarin een reeks arbeidsovereenkomsten feitelijk bestaat uit een afwisseling van tijdelijke contracten en uitzendcontracten. De Hoge Raad oordeelde dat de werkgevers als opvolgend moesten worden beschouwd en dat op grond daarvan feitelijk een arbeidsovereenkomst voor onbepaalde tijd tot stand was gekomen. In het Agfa-arrest betrof het een werkneemster die bij haar werkgever opvolgende tijdelijke nul-urencontracten op uurloonbasis had, zonder garantie met betrekking tot de werkzaamheden en de omvang daarvan. Feitelijk was de betreffende werkneemster praktisch voor de volledige werktijd werkzaam en verrichte ze dezelfde werkzaamheden als het personeel in vaste dienst. Ze ontving echter minder loon dan het vaste personeel. De Hoge Raad kwam tot het oordeel dat hier een arbeidsverhouding ontstaan was die zich inhoudelijk in niets of vrijwel niets onderscheidde van arbeidsverhoudingen van vergelijkbaar vast personeel. Daaraan werd de conclusie verbonden dat de werkgever de betreffende werkneemster hetzelfde loon moest betalen als het vaste personeel. In beide arresten prikte de Hoge Raad schijnconstructies door en liet de werkelijkheid prevaleren.

In deze arresten had de Hoge Raad het gebruik van verschillende tijdelijke contracten achter elkaar als het ware genormaliseerd conform het uitgangspunt van het arbeidsrecht, waarin het vaste contract de gebruikelijke vorm is. In feite was het een poging om de sluisdeuren dicht te houden terwijl er een vloedgolf van tijdelijke, wat betreft omvang en duur onzekere, en andere flexibele contracten was ontstaan. De Stichting van de Arbeid, en dan uiteraard vooral de werknemerskant, had de wetgever nodig om die rechterlijke 
uitspraken te codificeren. Als het daarbij was gebleven was eenvoudig de bescherming aan werknemerszijde versterkt. Maar daar bleef het niet bij. De sociale partners gingen flexibele arbeid presenteren als een spel waarin voor zowel werkgevers als werknemers wat te winnen viel. Werd het in Nederland nog flex\&zekerheid genoemd, in het buitenland werd het model bekend als 'flexicurity', hetgeen in één woord een wel heel innige verstrengeling is van wat in eerste instantie toch tegengestelde belangen zijn. De onderliggende gedachte, verwachting, of misschien wel hoop die uit het advies spreekt, is dat als werkgevers als eerst verantwoordelijke actor in hun onderneming meer werk maken van interne flexibilisering, en werknemers zich door zich te blijven scholen en wat flexibel op te stellen meer employable houden, zij er in hun gezamenlijke werkverband wel uitkomen. Mocht dat niet het geval zijn, dan is de inmiddels employable werknemer goed geëquipeerd voor een nieuwe baan. Een vergelijkbare uitruil werd ontwikkeld voor de uitzendovereenkomst. De vergunningplicht en maximale uitzendduur werden opgeheven. Vanwege de positief gewaardeerde allocatieve functie die uitzendbureaus op de arbeidsmarkt bekleden, werd deze vorm van ter beschikking stellen van arbeidskrachten ingebed in de arbeidsovereenkomst. Daarbij werd wel de voorwaarde gesteld dat naarmate de duur van de arbeidsrelatie vordert, de binding over en weer tussen uitzendkracht en uitzendbureau moet toenemen. De nota laat overigens zien dat de ook nu nog vaak gebezigde opmerking 'dat de tegenstanders van flex zich moeten realiseren dat een baan voor het leven bij dezelfde werkgever niet meer bestaat' ook toen al hopeloos achterhaald was, omdat beide zijden van het bedrijfsleven al in 1996 van deze werkelijkheid waren doordrongen. Flex moest niet zozeer bestreden, maar beter geregeld worden.

De wetgever ging mee in de flexibiliteit en zekerheidsgedachte waarbij de partijen er zelf wel uit zouden komen, en koos de term zelfs als titel voor de Wet Flexibiliteit en Zekerheid, 14 mei 1998, Stb. 1998, nr. 30o. Er werd ter bescherming van de werknemers een rechtsvermoeden van (de omvang van) de arbeidsovereenkomst ingesteld, een minimumaantal uren loon per oproep vastgesteld en de proeftijd werd enigszins beperkt. Daarmee werd een instrument gecreëerd om de onduidelijkheid omtrent de aard en de omvang van de arbeidsovereenkomst aan te pakken. Ook de regeling voor arbeidsovereenkomsten voor bepaalde tijd werd gewijzigd. Het gebruik van tijdelijke arbeidsovereenkomsten is zo oud als het arbeidsrecht. Tot de invoering van het moderne ontslagrecht in 1953 was het zelfs de meest zekere contractvorm, omdat de werknemer in elk geval voor die periode van inkomen was verzekerd. Maar in de jaren voorafgaand aan de wet was de tijdelijke arbeidsovereenkomst steeds meer het instrument van onzekerheid 
geworden. De wijzigingen van de Wet flexibiliteit en zekerheid betekenden ogenschijnlijk een verslechtering voor de werknemers, omdat voor die tijd een overeenkomst voor bepaalde tijd slechts eenmaal kon worden verlengd voordat deze voor onbepaalde tijd ging gelden. Dat werd vervangen door de ketenregeling, op grond waarvan na drie jaar of drie verschillende schakels een arbeidsovereenkomst voor onbepaalde duur tot stand komt. Daardoor ontstond minder snel een alles-of-nietskeuze voor de werkgever, waardoor de arbeidsrelatie ook langer kon worden gecontinueerd.

De regeling van de uitzendrelatie van 1999 is de enige keer in het ruim honderdjarige bestaan van de wettelijke regeling van de arbeidsovereenkomst, dat een wezenlijke wijziging van de definitie van de individuele arbeidsovereenkomst in de wet werd doorgevoerd. Uitzendarbeid was een fenomeen dat al vanaf de jaren 70 bestond. Oorspronkelijk werd het beschouwd als een vorm van arbeidsbemiddeling, naast de publieke arbeidsbemiddeling van het toenmalige arbeidsbureau. Over de juridische aard van de arbeidsrelatie werd in de ontstaansjaren niet principieel nagedacht. Eigenlijk was slechts de publiekrechtelijke kant geregeld. Uitzendbureaus moesten een vergunning hebben, waaraan voor het uitzendbureau verplichtingen waren verbonden. Schending van die verplichtingen kon in een aantal gevallen een economisch delict opleveren. Arbeidsrechtgeleerden slaagden er voor 1999 niet in de uitzendrelatie te duiden binnen het wettelijke stramien van de arbeidsovereenkomst, waarin een definitie wordt gehanteerd die slechts één werkgever en één werknemer onderkent. Het is in zekere zin logisch dat ze daar niet uitkwamen, want in plaats van twee partijen die over en weer de rechten en plichten verdelen waarvan in het Burgerlijk Wetboek sprake is, bestaat de uitzendrelatie uit drie partijen: het uitzendbureau, de werkende en de inlener. De uitzendrelatie werd een bijzondere arbeidsovereenkomst. De vergunningsplicht werd afgeschaft en overheidsbemoeienis werd niet meer nodig geacht, hetgeen goed paste in het toenmalige neoliberale dereguleringsklimaat (Rayer, 2014, p. 247). Het uitzendbureau werd werkgever in de zin dat de arbeidsvoorwaardelijke verplichtingen met betrekking tot de betaling van loon en de overige arbeidsvoorwaarden daar kwamen te liggen. Maar het gezag werd afgesplitst van de overige verplichtingen en kwam bij het inlenende bedrijf terecht. In de praktijk begon men te spreken over een verschil tussen een formeel en een materieel werkgeverschap. Het eerste half jaar is het gewone arbeidsrecht niet onverkort van toepassing verklaard en kan de overeenkomst per direct worden beëindigd als de opdrachtgever waar de werknemer te werk is gesteld de opdracht beëindigt. Na die periode gaat de uitzendrelatie steeds meer lijken op een gewone arbeidsovereenkomst 
waarop bijvoorbeeld ook een groot deel van het ontslagrecht van toepassing is.

Het 'voor ieder wat van zijn gading'-model van de Wet flexibiliteit en zekerheid, waarin de partijen er samen wel uit zouden komen, werd nog sterker door het grotendeels (driekwart) dwingende karakter ervan. Daarbij mag bij cao van de wettelijke regels worden afgeweken, vanuit ook weer de gedachte dat via autonome rechtsvorming de sectorale sociale partners beter in staat zijn om te bepalen hoe feitelijk in hun sector gewerkt moet worden. Zo kon de keten van tijdelijke contracten bijvoorbeeld bij cao eindeloos worden opgerekt en de termijnen waarop een uitzendovereenkomst steeds meer gelijk wordt aan een gewone arbeidsovereenkomst bij cao worden verlengd. In de praktijk werd daarvan vervolgens gebruikgemaakt, maar ook kwam het voor dat bij cao de regelingen juist werden beperkt (Houwing, 2010, p. 161-162).

\section{Van 1996 naar 2015: verdere fragmentering van arbeidsrelaties}

\section{Een groeiend leger 'arbeidsnomaden'?}

Opvallend is dat in de inleiding van de nota 'Flexibiliteit en Zekerheid' al de vrees wordt uitgesproken dat: 'in de toekomst naast een harde kern van "vaste" werknemers, een groeiend legertje van "arbeidsnomaden" zal ontstaan, bestaande uit mensen die doorlopend van de ene tijdelijk baan naar de andere onderweg zijn, met alle onzekerheden van dien.' Bovendien werd reeds toen geconstateerd dat het socialezekerheidsstelsel, met name wat betreft ziekte, niet was ingericht om deze onzekere werkenden voldoende bescherming te bieden. De wetgeving van 1998 moest een remedie leveren om die ontwikkeling in goede banen te leiden. De hamvraag voor vandaag ligt daarom voor de hand: bestaat in 2015 een populatie van flexibel werkenden, bestaande uit dit soort 'arbeidsnomaden', die wellicht ook buiten de bescherming van de socialezekerheidsregelingen vallen? En vervolgens de vraag: zijn werkgevers conform de voornemens van 1996 vooral aan de slag gegaan met de ontwikkeling en verbetering van interne flexibiliteit in de ondernemingen? Het antwoord op beide vragen is eigenlijk al door de Stichting van de Arbeid gegeven en valt hierboven in paragraaf 2 te lezen: 'Er is in toenemende mate sprake van doorgeschoten flex.' Dat roept een aantal vervolgvragen op. Hoe ziet die doorgeschoten flex eruit, die ondanks het vorige sociaal akkoord en de daaruit voortvloeiende wetgeving toch is ontstaan? Zijn de partijen die vertegenwoordigd zijn in de Stichting van 
de Arbeid zelf ook betrokken bij de ontwikkeling ervan of zijn outsiders ervoor verantwoordelijk? Wat zegt dat vervolgens over het sociaal akkoord als instrument? Kan of moet het worden aangepast of kan er beter een alternatief voor worden gevonden?

\section{Toenemend gebruik van 'oude vormen van flex'}

Laten we eerst eens onderzoeken hoe het verder is gegaan met de wijzigingen van 1998 en de mogelijkheid om er bij cao van af te wijken. We bekijken achtereenvolgens: de rechtsvermoedens van aard en omvang van de arbeidsrelatie oftewel de nuluren- en min/maxcontracten; de ketenregeling van tijdelijke arbeidsovereenkomsten en de uitzendarbeidsovereenkomst.

Op het terrein van de juridische vorm en aard van de arbeidsovereenkomst hebben zich in de afgelopen jaren twee belangrijke ontwikkeling voorgedaan: de voortzetting van de groei van nuluren- en min/maxcontracten en de groei van het aantal zelfstandigen zonder personeel. De eerste constatering is dat aan de opmars van nulurencontracten en $\mathrm{min} /$ max-contracten geen einde is gekomen. Vooropgesteld wordt dat een nulurencontract geen juridisch begrip is, maar in de praktijk wordt gebruikt voor een tijdelijke of vaste arbeidsovereenkomst, waarin is overeengekomen dat geen loon wordt betaald als niet wordt gewerkt. Het is niet goed mogelijk om aan te geven hoeveel mensen momenteel op basis van nulurencontracten werken, omdat het CBS niet registreert welk deel van de werknemers dat als oproep- of invalkracht werkt (258.00o in het derde kwartaal van 2013) dat op basis van een nulurencontract doet. In de tweede evaluatie van de Wet flexibiliteit en zekerheid uit 2007 (Knegt et al., 2007) wordt wel een percentage gegeven dat enige indicatie kan geven. In die evaluatie gaf een kleine 70 procent van de respondenten met een oproepcontract aan op basis van een nulurencontract te werken. Extrapolerend naar de huidige situatie, zou dat betekenen dat minstens 180.000 mensen op basis van een nulurencontract werken. Dit getal dient echter volgens het CBS met de nodige voorzichtigheid te worden geïnterpreteerd, omdat het gebaseerd is op verouderde informatie. ${ }^{12}$

Een groeiend aantal werkenden werkt niet langer onder het gezag van een werkgever, maar verhuurt zijn eigen arbeid als zelfstandige zonder p. 13 . 
personeel. In het derde kwartaal van 2014 was hun aantal al ruim 800.00o. ${ }^{13}$ $\mathrm{Zij}$ zijn voor de belastingdienst en ook in overige juridisch-technische zin ondernemers die voor eigen risico hun onderneming voeren, die vaak enkel uit arbeid bestaat. De meningen over aantallen zijn verdeeld, maar het is zeker dat een flink deel van deze groep hiervoor heeft gekozen en een kleiner aandeel zich ertoe voelt gedwongen (CPB, 2012, p. 5). Daar moeten we verschillende situaties onderscheiden. Werkenden kunnen zich gedwongen voelen door de omstandigheid dat ze geen werk in loondienst kunnen vinden, terwijl zij dat wel graag zouden willen. Maar het kan ook zo zijn dat zij uit hun dienstverband zijn ontslagen en vervolgens van hun werkgever het aanbod hebben gekregen om als zelfstandige opdrachtnemer dezelfde arbeid in dezelfde werkomgeving te verrichten. In elk geval die laatsten zullen vaak schijnzelfstandigen zijn. Als zij naar de rechter zouden stappen zou die waarschijnlijk de relatie als arbeidsovereenkomst duiden. Naar de rechter stappen is echter een risicovolle stap, die veelal zal leiden tot verlies van de opdracht en het daarbij behorende inkomen. Hoe deze verhoudingen ook liggen, het is duidelijk dat een groot deel van de zzp'ers dezelfde maatschappelijke risico's draagt als werknemers, terwijl ze de aan de arbeidsovereenkomst gekoppelde sociale bescherming vaak ontberen (Kok et al., 2014). Wel heeft deze groep bepaalde belastingvoordelen ten opzichte van werknemers. Zelfstandigen hebben zich georganiseerd in bij de vakcentrales aangesloten vakbonden en bezetten bovendien vanuit die vertegenwoordiging een zetel in de SER. Op grond van de mededingingswetgeving is het 'echte' zelfstandigen, dat wil zeggen ondernemers, niet toegestaan om op dezelfde voet als andere werkenden te onderhandelen over hun tarieven. ${ }^{14}$ Het EU Hof van Justitie heeft echter in december 2014 bepaald dat voor zelfstandigen die als het ware opgaan in een arbeidsorganisatie waar hun werk ook in een arbeidsovereenkomst wordt verricht, wel tariefafspraken mogen worden gemaakt. Dat Hof trekt die zzp'ers dus wel in het arbeidsrecht. Het maatschappelijk debat over de zzp'er is zodanig gepolariseerd dat het lastig is om een rustige discussie te voeren over de verdeling van winst, risico en bescherming voor deze groep. Dat geldt zeker, waar blijkt dat een flink deel van de zzp'ers onvoldoende inkomsten heeft om premie te betalen voor sociale voorzieningen waarvan zij wel gebruik kunnen maken, terwijl zij wel fiscale voordelen genieten. ${ }^{15}$

13 http://statline.cbs.nl/StatWeb/publication/?DM=SLNL\&PA=80150NED\&D1=a $\& \mathrm{D}_{2}=0-7 \& \mathrm{D}_{3}=\% 28 \mathrm{l}-3 \% 22-1 \& \mathrm{HDR}=\mathrm{T} \& \mathrm{STB}=\mathrm{G} 2, \mathrm{G} 1 \& \mathrm{VW}=\mathrm{T}$.

14 EU Hof van Justitie C-413-13 Kiem/de Staat der Nederlanden (NMa).

15 'Belastingvoordeel zzp'er ondergraaft de solidariteit', FD 12 november 2014. 
De onderlinge concurrentie tussen zzp'ers kan groot zijn, en om toch aan opdrachten te komen kunnen zij de prijs voor arbeid omlaag brengen. Ten opzichte van de prijs van werknemers worden zij dan zo goedkoop, dat er al snel verdringing van gewoon werk naar zelfstandigheid kan plaatsvinden.

De geschiedenis toont aan dat de ketenregeling voor tijdelijke contracten van 1999 niet heeft waargemaakt waar het om was begonnen. De bedoeling was weliswaar enige tijd onzekerheid, maar na die periode, als partijen elkaar goed hebben leren kennen, een vaste arbeidsrelatie. Met name door de mogelijkheid om in een collectieve arbeidsovereenkomst af te wijken van de regeling, is in bepaalde sectoren een praktijk van permanent gebruik van tijdelijke contracten ontstaan, in situaties waarin het werk eigenlijk steeds op dezelfde wijze wordt voortgezet. Namelijk door steeds weer nieuwe werknemers aan te nemen of door een werknemer in dienst te nemen die er steeds een tijd tussenuit moet, om daarna weer kans te maken op een nieuwe arbeidsovereenkomst zonder dat een langdurig dienstverband ontstaat. Deze vorm van flexibele arbeid leidt in de praktijk het meest tot onzekerheid over toekomstige inkomsten, zeker in combinatie met een onzeker aantal uren werk door een nuluren- of $\mathrm{min} / \mathrm{max}$-constructie. Bovendien zorgt het voor een situatie waarin de werknemer niet goed voor zichzelf kan opkomen: beëindiging van zijn arbeidsovereenkomst hangt immers steeds in de lucht als hij zich voor de werkgever lastig opstelt.

Het regelen van de uitzendrelatie heeft op zichzelf goede effecten gehad voor zowel de werkgevers- als de werknemerskant. De arbeidsverhoudingen in een groot deel van de uitzendsector kunnen ook zonder meer als positief worden gekenschetst. Langlopende afspraken in cao's en andere overlegvormen maken dit deel van de arbeidsmarkt grotendeels 'bonafide', waar het in andere landen vaak niet anders kan worden benoemd dan als 'malafide'. Als in Nederland aan de onderkant van de uitzendmarkt ook malafide bedrijven bestaan, dan is om die misstanden te bestrijden in elk geval een mechanisme ontwikkeld dat stevig wordt gedragen door de meest betrokken partijen. Bovendien is voor de handhaving van de privaatrechtelijke regels een organisatie opgezet die de naleving van de normen controleert en certificering verzorgt voor ondernemers die zich aan het systeem verbinden. ${ }^{16}$ De overheid heeft aan een zodanig certificaat een vrijwaringsrecht voor aansprakelijkheid voor fiscale en socialezekerheidsverplichtingen verbonden. Maar de legitimering van het opsplitsen 
van de werkgeversrollen in een formeel en een materieel deel heeft ook ander effecten gehad. Of het oorzaak of gevolg is, bevalt te betwisten, maar aan werkgeverszijde werd de gedachte 'wel de lusten, niet de lasten' van de arbeidsovereenkomst populair. Als daarvoor tijdelijke uitzendarbeid was gebruikt was dat tot daaraan toe geweest. Maar uitzendondernemers zijn speciale businessmodels gaan ontwikkelen voor min of meer permanente ter beschikkingstelling. Het voorbeeld bij uitstek van dit laatste fenomeen is het payrollen. De werkgever die de arbeid gebruikt, heeft de voordelen van de uitzendconstructie. Een ondernemer werft en selecteert een werknemer, maakt alle arbeidsvoorwaardelijke afspraken, maar laat vervolgens de arbeidsovereenkomst ondertekenen door een uitzendondernemer. Vervolgens kan het voorkomen dat de werknemer jarenlang onder veel slechtere arbeidsvoorwaarden werkt dan zijn collega's die vaak hetzelfde werk doen. Wanneer de werkgever de werknemer wil ontslaan, dan kan dat zonder verplichtingen voor beide werkgevers, die hun zaakjes zo hebben gesplitst dat het voor de werknemer moeilijk is om vast te stellen bij welke partij hij zijn recht moet halen.

\section{In 1999 onvoorziene ontwikkeling van nieuwe vormen van 'flex'}

De recentste variant van outsourcen van het hele personeelsbestand aan een derde wordt 'contracting' genoemd, en kwam onder meer aan het licht doordat de huidige minister van Sociale Zaken en Werkgelegenheid er op een van zijn eerste ambtsdagen mee werd geconfronteerd. Het betrof de onderneming Sierofor, een bloemendistributiebedrijf dat ertoe overging het gehele productiepersoneel te ontslaan om vervolgens de activiteit op de eigen werkplek over te doen aan een productiebedrijf. Het personeel dat vervolgens door dat bedrijf zou worden aangenomen zou niet langer onder de cao komen te vallen. De rechter oordeelde dat de ontslagen doorgang zouden vinden, maar tevens dat:

Centraal in het debat tussen partijen staat de vraag of een werkgever de arbeidsovereenkomsten met de vaste werknemers kan beëindigen, wanneer het werk wordt uitbesteed aan een ander bedrijf, die het werk gaat verrichten met meer flexibele en niet onder de cao van de werkgever vallende arbeidskrachten. Die vraagstelling kan naar het oordeel van de kantonrechter niet los worden gezien van de ingrijpende veranderingen die zich voltrekken op (vooral de onderkant van) de arbeidsmarkt in een groot aantal sectoren, mede een gevolg van de toegenomen arbeidsmigratie uit Midden- en Oost-Europa en een daarmee 
samenhangende scherpe concurrentie ten aanzien van arbeidsvoorwaarden en arbeidsproductiviteit. ${ }^{17}$

Die achtergrond mocht ondanks meer menselijk dan juridisch begrip van de rechter voor de situatie de werkneemsters niet baten:

In die situatie doet zich de in aanhef omschreven ontwikkeling hard voelen. Ook bestaat alle begrip voor de frustraties van de werknemers over de abrupte wijze waarop het verval van de arbeidsplaats is medegedeeld en over de omstandigheid dat vervolgens het uitbestede productiewerk onder de neus van de werknemers werd uitgevoerd door anderen. Dit laatste echter legt, hoe zuur ook, geen gewicht in de schaal voor de vraag of sprake is van reguliere uitbesteding, nu al jarenlang door het productiebedrijf met eigen productiemiddelen en personeel (ook) in de bedrijfshal van Sierafor werd gewerkt.

Het outsourcen van taken die niet tot de kern van de onderneming behoren, is in de laatste vijftien jaar exponentieel gegroeid. Waar in de vorige eeuw de meeste schoonmaak-, catering-, en beveiligingsmedewerkers in een onderneming in dienst waren bij de werkgever die de onderneming in stand hield, kwam een beweging op gang waarbij dit personeel in dienst kwam bij specifiek op die vormen van dienstverlening gerichte ondernemingen. Er is een handel ontstaan in opdrachten, die vervolgens ook in voorkomende gevallen grensoverschrijdend is. Wanneer een werknemer ergens in die keten een beroep wil doen op het arbeidsrecht, dan komt het nogal eens voor dat werkgevers naar elkaar wijzen of dat de feitelijke werkgever onvindbaar is. De wettelijke bepaling met betrekking tot overgang van onderneming beschermt een deel van deze werknemers in eerste instantie nog tegen de achteruitgang van hun arbeidsvoorwaarden, maar ook daar geldt dat het juridisch afdwingen betekent dat een moeizame weg moet worden bewandeld. Aan- en uitbesteden zorgt zowel in de publieke als private dienstverlening voor grote onzekerheid voor de werknemers, terwijl zij zelf niet kunnen beïnvloeden wie in een bepaalde periode hun werkgever of diens opdrachtgever zal zijn. Het aanbestedingsproces leidt tot een permanente neerwaartse druk op de arbeidsvoorwaarden, omdat de partijen die de prijs van de arbeid bepalen, bijvoorbeeld in sectoren als de schoonmaak en de thuiszorg, niet aan de cao-onderhandelingstafel zitten. In de schoonmaaksector liep de spanning in de afgelopen jaren zodanig op dat in 2010, 
2012 en 2014 lange stakingen uitbraken. Het bijzondere bij deze acties was dat in de loop der tijd enkele werkgevers ertoe overgingen toe te geven dat ze voor projecten intekenden tegen een prijs die niet houdbaar was zonder de werknemers onder grote tijdsdruk te plaatsen. Zij stelden echter dat de opdrachtgevers hen dwongen tot die oneerlijke concurrentie. Uiteindelijk werd in de schoonmaaksector een convenant in de vorm van een code gesloten, waarbij de drie partijen waren betrokken: schoonmaakbedrijven, vakbonden van schoonmakers en ook de grote opdrachtgevers als NS en Schiphol. ${ }^{18}$ Eind 2014 is een zodanige code opgesteld, niet slechts voor de schoonmaaksector maar voor alle sectoren waar dergelijke driehoeksrelaties bestaan. Die code kan echter tot geen enkele juridische binding leiden.

\section{Grensoverschrijdende detachering, vaak met gebruik van flexcontracten}

Dat brengt ons bij de volgende juridische verschijningsvorm van de werkgever: de dienstverlener uit een ander EU-land; de Europese sub-variant van globalisering. Een van de vele voorbeelden daarvan is een in Nederland gevestigde transportonderneming die in Polen een andere onderneming start, van waaruit vervolgens Poolse chauffeurs worden uitgezonden die het werk van de Nederlandse chauffeurs overnemen. De rechter vindt dat er sprake is van enige vereenzelviging tussen de ondernemingen, maar omdat deze niet totaal is, meent hij toch dat zich in Polen de formele werkgever bevindt en in Nederland de materiële. ${ }^{19}$ In dit geval was de band tussen de ondernemingen zeer sterk, maar daar hoeft uiteraard helemaal geen sprake van te zijn. Ondernemers in de ene EU-lidstaat hebben het recht hun diensten te leveren in een andere lidstaat. Omdat dit vaak een activiteit in een andere onderneming zal zijn, is ook daar weer sprake van meerdere werkgevers op één werkplek. De EU-regelgeving voor grensoverschrijdende dienstverlening, de zogenaamde detacheringsrichtlijn, bepaalt dat als sprake is van detachering, een kern van arbeidsrecht moet worden toegepast. Niet alleen het wettelijke arbeidsrecht - dat zou zoals wij eerder zagen voor Nederland niet zoveel betekenen -, maar ook de arbeidsvoorwaarden van de cao, op voorwaarde dat deze algemeen verbindend is verklaard. De gedachte daarachter is logisch: er moet een gelijk speelveld zijn voor binnen- en buitenlandse dienstaanbieders. De juridische werkelijkheid is echter een geheel andere dan hoe het op vele werkplekken uitpakt, en 
handhaving en naleving van het arbeidsrecht voor deze werknemers zijn uitermate moeilijk tot onmogelijk gebleken. Inmiddels is in Brussel wel een richtlijn aangenomen die de handhaving van deze normen moet verbeteren. Deze zal in juni 2016 moeten zijn geïmplementeerd. ${ }^{20}$ Op grond daarvan zal een buitenlandse dienstenaanbieder in elk geval een registratie van voor elk van zijn werknemer geldende arbeidsvoorwaarden moeten verzorgen en aan de Arbeidsinspectie kunnen tonen.

\section{Kan de geest weer in de fles, of moeten we een ander systeem ontwerpen?}

Als we resumeren naar aanleiding van de vraag of het sociaal akkoord van 1996 en de daaropvolgende wetgeving een dam hebben opgeworpen tegen door de betrokkenen zowel toen als nu ongewenst geachte vormen van flexibele arbeid, dan is het antwoord grotendeels negatief. Uiteraard valt niet goed vast te stellen of zonder de initiatieven toentertijd de uitkomst nog veel slechter zou zijn, maar op de effectiviteit is zeer veel af te dingen. Dat roept de vraag op of het Nederlandse overlegmodel wel voldoende grip heeft op de ontwikkelingen aan de onderkant van de arbeidsmarkt. De niet in het systeem vertegenwoordigde actoren, zowel de nationale partijen die zich niet vertegenwoordigd voelen als ondernemers die van buiten Nederland hun diensten op de markten aanbieden, hebben een zodanige invloed, of kunnen zo makkelijk ontsnappen aan het systeem van handhaving en naleving, dat het voor de werkgevers en werknemers die wel in de Stichting van de Arbeid vertegenwoordigd zijn moeilijk is om de centrale afspraken van de centrale akkoorden te handhaven. Ook in de cao's van de wel in het polderoverleg betrokken partijen is neerwaarts afgeweken van de afspraken die toen zijn gemaakt. Dat leidt tot de vraag of de achterban van werkgeverskant die in het centraal overleg is vertegenwoordigd, zich eigenlijk aan de cao-tafel ook gebonden acht aan die afspraken. En vervolgens tot de vraag waarom het de vakbonden niet lukt om de decentrale werkgevers met wie zij de cao's overeenkomen te binden aan de afspraken van het centrale overleg.

Het sociaal akkoord van 2013 en de daaruit voortvloeiende wetgeving die erop is gestoeld adresseert een aantal van deze ontwikkelingen met betrekking tot flexarbeid, net zoals dat eind jaren go het geval was. Inmiddels

20 Richtlijn 2014/67/EU van het Europese Parlement en de Raad van 15 mei 2014 inzake de handhaving van Richtlijn 96/71/EG betreffende de grensoverschrijdende terbeschikkingstelling van werknemers. 
(september 2015) is de regering flink op weg om het grootste deel van de afspraken van het sociaal akkoord te implementeren in wetgeving. Veel van de onderwerpen hebben een plek gevonden in de Wet werk \& zekerheid, die een grondige herziening van het ontslagrecht behelst. ${ }^{21}$ Daarin is onder meer een kortere ketenregeling voor tijdelijke arbeidsovereenkomsten opgenomen en een transitievergoeding bij beëindiging van de arbeidsovereenkomst die gelijk is voor werknemers met een vast en die met een tijdelijk contract. Verder is ten aanzien van het payrollen een bijzondere regeling ontworpen. Bij verval van arbeidsplaatsen moet het payrollbedrijf aantonen dat de door dit bedrijf ter beschikking gestelde werknemer bij het inleenbedrijf voor ontslag in aanmerking komt op grond van het afspiegelingsbeginsel. Dat wil zeggen dat wat betreft ontslag de gepayrollde werknemer wordt beschouwd als een werknemer van het inleenbedrijf. Voor het eerst wordt daarmee de splitsing in materieel en formeel werkgeverschap gebruikt ten behoeve van het belang van de werknemer in plaats van dat van de werkgever.

Ten aanzien van de handel in arbeidsintensieve diensten die is ontstaan door uitzending, uitbesteding, aanbesteding, contracting en sub-contracting, en de negatieve gevolgen die dit soort verschijnselen hebben voor de werknemers, is gekozen voor de invoering van een wettelijke ketenaansprakelijkheid voor loonbetaling. ${ }^{22}$ Op grond daarvan kan een werknemer die werkzaam is op bijvoorbeeld een bouwplaats waar veel van het werk door (een keten van) onderaannemers wordt uitgevoerd, onder voorwaarden ook de hoofdaannemer en de andere opdrachtgever(s) aansprakelijk stellen als zijn eigen werkgever tekortschiet in de naleving van zijn arbeidsovereenkomst. Die ketenaansprakelijk geldt ook, of beter gezegd juist, voor grensoverschrijdende dienstverlening, waar de praktijk vaak laat zien dat de verantwoordelijke voor schendingen van het arbeidsrecht onvindbaar is. In dit kader wordt ook een intensievere informatie-uitwisseling gefaciliteerd van de inspectie-SZW naar de cao-partijen. Dat betekent dat deze partijen met informatie die de overheid heeft verkregen op de werkplekken,

21 Stb. 2014, 216, Wet van 14 juni 2014 tot wijziging van verschillende wetten in verband met de hervorming van het ontslagrecht, wijziging van de rechtspositie van flexwerkers en wijziging van verschillende wetten in verband met het aanpassen van de Werkloosheidswet, het verruimen van de openstelling van de Wet inkomensvoorziening oudere werklozen en de beperking van de toegang tot de Wet inkomensvoorziening oudere en gedeeltelijk arbeidsongeschikte werkloze werknemers (Wet werk en zekerheid).

22 Stb. 233, 2015, Wet van 4 juni 2015 tot wijziging van de Wet minimumloon en minimumvakantiebijslag, Boek 7 van het Burgerlijk Wetboek en enige andere wetten ter verbetering van de naleving en handhaving van arbeidsrechtelijke wetgeving in verband met de aanpak van schijnconstructies door werkgevers (Wet aanpak schijnconstructies). 
die uiteraard voor de overheid makkelijker toegankelijk zijn dan voor de vakbonden, een rechtsgang kunnen maken om naleving van de cao te effectueren.

Met betrekking tot de complexe problematiek van de zzp'ers heeft de regering een interdepartementale werkgroep ingesteld die allerlei aspecten van deze arbeidsrelatie analyseert. Interessant daarbij is dat in de opdracht de prijs van de arbeid gekoppeld wordt aan een analyse van de oorzaken en motieven achter het toenemend aantal zzp'ers, waarbij in ieder geval de samenhang met werkgeverslasten, arbeidsrecht, fiscale (ondernemers) faciliteiten, socialezekerheidswetgeving en premie- en lastendruk wordt bezien. Ook wordt gekeken naar de vraag of zich momenteel in bepaalde sectoren - zoals de zorg - belemmeringen voordoen in bijvoorbeeld de arbeidstijdenwet en/of in cao's om voldoende flexibiliteit te realiseren binnen het kader van de arbeidsovereenkomst. Verder wenst de regering een analyse van de gevolgen van het toenemend aantal zzp'ers voor de economische ontwikkeling, het socialezekerheidsstelsel, en de houdbaarheid van de overheidsfinanciën - sluiten sociale zekerheid en fiscaal instrumentarium nog aan op de moderne arbeidsmarkt? Het sluitstuk van het onderzoek moet zijn het formuleren van beleidsvarianten om de effectiviteit en efficiëntie van het instrumentarium rondom zzp'ers te verhogen en de houdbaarheid van het socialezekerheidsstelsel en de overheidsfinanciën te garanderen, waarbij zowel oog is voor de baten als voor de kosten van de instrumenten, en waarbij het gelijke speelveld tussen zzp'ers, zelfstandigen met personeel en werknemers in ogenschouw wordt genomen (CPB, 2014).

\section{Conclusie}

De motor van het Nederlandse overlegmodel heeft de afgelopen twee jaren op volle toeren gedraaid. Net zoals dat het geval was eind jaren 9o, de periode dat Visser en Hemerijck hun 'mirakelboek' publiceerden. Inhoudelijk wordt wat betreft de wijzigingen in het arbeidsrecht een vergelijkbare exercitie uitgevoerd als aan het einde van de vorige eeuw. Maar wat betekent dat? Dat net als toen de overheid als wetgever en bestuurder op verzoek van de sociale partners een juridische gereedschapskist opnieuw vult, waarmee zij vervolgens hun inzet kunnen verzilveren. Dit model heeft ontegenzeggelijk meer voordelen dan nadelen. Het draagvlak in de samenleving dat de werkgeversorganisaties en vakbonden aan politieke besluiten verschaffen, maakt de positie van de wetgever stabiel. De wetgever weet dat het gereedschap dat hij heeft ontworpen ook zal worden gebruikt. De gebruikers kennen de 
wetgeving door-en-door, omdat zij zelf bij de vormgeving betrokken zijn geweest en loyale ondersteuners zijn geweest van het wetgevingsproces.

Maar hebben de betrokkenen geleerd van de nadelen die het model ook kent? Het eerste nadeel betreft het compromiskarakter van de sociale akkoorden. In het begin van dit hoofdstuk werd al gesteld dat een sociaal akkoord niet alleen een overeenkomst is maar ook een afspraak 'to-agreeto-disagree'. Dat betekent dat de problemen die op de arbeidsmarkt leven al direct in de trechter wordt gegoten van het compromis tussen werkgevers en werknemers van het nationale georganiseerde bedrijfsleven. Vervolgens kunnen zij, zeker gezien hun soms gespannen relatie met hun achterban en omgeving, niet al te ver voor de eigen troepen uit gaan lopen. Wanneer de overheid die afstand wel neemt, dan zullen zij dat wellicht niet als loyaal beschouwen. Zij zijn immers de initiatiefnemers van de ontwikkelingen. Die werkelijkheid van het op zich vaak zo succesvolle proces kan als gevolg hebben dat aan bepaalde onderliggende of met de problematiek samenhangende aspecten onvoldoende aandacht wordt besteed in het wetgevingsproces. De uitkomst kan dan zijn dat de wijzigingen niet het onderliggende probleem aanpakken, in dit geval bijvoorbeeld neerwaartse druk die de prijs van buitenlandse flexarbeid op onze arbeidsmarkt heeft. Een druk waarvoor vervolgens ook deelnemers aan het sociaal overleg kunnen bezwijken als zij hun inzet voor de in de sector geldende cao's bepalen.

Het tweede nadeel van de in dit hoofdstuk beschreven verhouding tussen wetgeving en cao's betreft de verdeling tussen overheid en sociale partners van de verantwoordelijkheden in de handhaving van het arbeidsrecht. De publieke handhavingsfunctie van de arbeidsinspectie is in Nederland relatief klein en betreft slechts de wettelijke minimumarbeidsomstandigheden, minimumloon en minimumarbeidstijden. Handhaving van arbeidsvoorwaarden is in ons systeem immers primair een private functie. Maar dat werkt niet goed op delen van de arbeidsmarkt die in theorie door ons cao-systeem worden bereikt, maar waar het voor die cao-partijen niet mogelijk is om toegang te krijgen. Zij hebben uiteraard geen wettelijke inspectiebevoegdheden. De sociale partners hebben weliswaar het privaatrechtelijke handhavingsinstrumentarium om het door hen gecreëerde level playing field te bewaken op werkplekken die door algemeenverbindendverklaring zijn gebonden. Maar feitelijk blijkt het geen eenvoudige opgave dit effectief in te zetten op de werkplekken waar de algemeen verbindend verklaarde cao's worden ontdoken. Omdat de afstand tussen de wettelijke minimumarbeidsvoorwaarden en die van de cao vaak betrekkelijk groot zijn, bestaat voor partijen die zich niet zelf verbonden hebben aan het systeem, maar het vanwege algemeenverbindendverklaring moeten toepassen, 
een constante sterke prikkel om het te ontduiken. Waar dat die partijen lukt, heeft dat weer een negatieve werking op de animo van andere werkgevers om een cao op een hoger niveau overeen te komen. Als de handhaving door de cao-partijen niet goed lukt, dan is dit als het ware slechts aan hun eigen gebrekkige handhavingsinzet te wijten.

Een politieke vraag is of dit eigenlijk nog wel fair en reëel is in de huidige tijd. Aan de onderkant van de arbeidsmarkt waar veel 'doorgeschoten flex' zo slecht is dat sprake is van uitbuiting, zou de overheid met haar steviger machtsmiddelen veel sterker kunnen optreden, zowel normstellend als handhavend. Als de gevolgen van de 'doorgeschoten flex' werkelijk door werkgevers en werknemers én de overheid als een zeer slechte zaak worden beschouwd, dan verdient het wellicht aanbeveling om de normen door de wetgever dwingend vast te laten stellen in wetgeving, zodat deze het level playing field kan handhaven.

Dat hoeft niet te betekenen dat de regelingsmacht van de sociale partners in zijn algemeenheid zou moeten worden verkleind, het betreft geen wet van communicerende vaten. De voordelen van het systeem voor de dagelijkse gang van zaken op de arbeidsmarkt - niet alles is doorgeschoten flex - wegen nog ruimschoots op tegen de nadelen die hiervoor zijn aangegeven. Maar het betekent wel dat opnieuw moet worden overwogen welke sociale kwesties binnen het bereik van de sociale partners vallen en welke daarbuiten. Waar het onderwerpen betreft die tot misstanden aan de onderkant van de arbeidsmarkt leiden, en waar bovendien blijkt dat het private handhavingssysteem geen oplossing biedt, zou de overheid in het politieke proces de eigen verantwoordelijkheid weer duidelijker kunnen formuleren en vervolgens meer naar zich kunnen toetrekken. 



\title{
$9 \quad$ In de schaduw van de markt?
}

\author{
Een reflectie op de robuustheid van looncoördinatie via \\ doorwerking ${ }^{1}$
}

Arjen Verhoeff

In de open Nederlandse economie staat sturing van de loonontwikkeling geregeld in de belangstelling. Wil Nederland bijblijven in de internationale concurrentieslag, dan is volgens beproefd economisch recept een gematigde loonontwikkeling vereist. Zo verwijst de Macro Economische Verkenning 2016 (CPB, 2015) naar de gunstige gematigde loonontwikkeling van de afgelopen jaren. De confrontatie van de visies van overheid en sociale partners op wat een verantwoorde ontwikkeling en verdeling van de lonen is, vindt in Nederland gewoonlijk plaats via de mechanismen van het tripartiete corporatistische stelsel, het zogenoemde poldermodel. Het poldermodel is zeker tot aan het begin van deze eeuw maatgevend geweest voor de coördinatie van economische en sociale ontwikkelingen (Touwen, 2014; Tros et. al., 2006; Visser en Hemerijck, 1997; Verhoeff en De Bruin, 2012). Een van die mechanismen betreft de coördinatie van de loonvorming, waar kabinet en sociale partners gestalte aan geven. De eigentijdse invulling van looncoördinatie begon met het Akkoord van Wassenaar (Stichting van de Arbeid, 1982), waarvan de startalinea luidt:

De in de Stichting van de Arbeid vertegenwoordigde centrale organisaties van werkgevers en werknemers: Overwegende dat essentieel voor een structurele verbetering van de werkgelegenheid is: Herstel van economische groei, een stabiel prijspeil, versterking van de concurrentiekracht van ondernemingen en in samenhang daarmee verbetering van de rendementspositie; (...).

Velen interpreteren het tripartiete akkoord van 1982 als de start van een lange periode van sociaaleconomische stabiliteit, waarbij centrale afspraken werden vertaald naar de totaliteit van afspraken in cao's. De collectieve arbeidsovereenkomst (cao) vormt het platform waar wordt onderhandeld

1 Veel dank is verschuldigd aan Geert de Bruin en Laurens Harteveld (AWVN) voor hun waardevolle bijdragen. Tevens gaat dank uit aan al degenen die hebben meegewerkt aan de interviewreeks. Deze bijdrage is geschreven op persoonlijke titel. 
over zowel het creëren van meerwaarde als over de legitimering van de uitkomsten. Het vertalen van een centrale afspraak naar het decentrale cao-niveau wordt doorwerking genoemd, een specifieke vorm van (loon) coördinatie. De vraag of het poldermodel zichzelf heeft overleefd wordt regelmatig gesteld en staat ook centraal in deze bijdrage. Anno 2015 heeft marktwerking sterk aan invloed gewonnen (SER, 2012), hetgeen liberalisering van de arbeidsverhoudingen met zich meebracht. Dagelijks getuigen krantenberichten van signalen over een oprukkende Angelsaksische bedrijfscultuur. De onzichtbare hand van vraag en aanbod zou bij economische tegenslag als vanzelf aanzetten tot loonmatiging (Friedman, 1970). Vanuit zo'n marktperspectief is het vanzelfsprekend tijd om de laatste resten van het Nederlandse corporatisme' van de hand te doen. De centrale vraag van deze bijdrage is of het beheersen van belangen via het maken van centrale afspraken met doorwerking naar het cao-niveau de dynamiek van de huidige eeuw kan doorstaan. Met name gaat de aandacht uit naar de vraag hoe de noodzakelijke voorwaarden voor doorwerking zich in deze eeuw hebben ontwikkeld.

De indeling van dit hoofdstuk is als volgt. In de volgende sectie wordt een toelichting gegeven op het concept van (loon)coördinatie en de noodzakelijke voorwaarden voor doorwerking. Tevens wordt de relevantie van de cao voor (loon)coördinatie geduid. De erop volgende twee secties bieden zicht op de praktijk van (loon)coördinatie: eerst laat de samenvattende beschrijving van de 'Wassenaarperiode' zien hoe de doorwerking geleidelijk aan gestalte kreeg. Vervolgens wordt de ontwikkeling van de doorwerking na 2000 in beeld gebracht. Tot slot van dit hoofdstuk volgt de conclusie hoe het beheersen van belangen via het maken van centrale afspraken met doorwerking naar het cao-niveau de sociaaleconomische dynamiek tot op heden heeft doorstaan.

\section{Coördinatie, doorwerking en de cao}

De coördinatie in het Nederlandse poldermodel kent veel facetten en een ervan is de coördinatie van de loonvorming. Loonoördinatie heeft gewoonlijk het oogmerk om lonen te matigen of aan te passen in tijden van crisis (Visser, 2013b, p. 56). Looncoördinatie kan plaatsvinden via de overheid, sociale partners of via marktwerking. Een overheid kan het coördineren van de loonvorming tot haar exclusieve domein rekenen, zoals de Nederlandse overheid tot 1982 de formele verantwoordelijkheid voor de loonvorming op zich nam. In plaats van deze harde coördinatie via loonpolitiek kan de overheid de coördinatie ook overlaten aan vertegenwoordigers van werkgevers respectievelijk werknemers, de sociale partners. In deze laatste situatie is coördinatie van loonvorming het synchroniseren van beloningsstrategieën 
van verschillende onderhandelpartijen (Traxler en Brandl, 2012, p. 74). Meer specifiek onderscheiden Traxler et al. (2001) verschillende vormen van coördinatie: naast statelijke controle respectievelijk door de overheid gefaciliteerde onderhandelingen, zijn er interprofessionele onderhandelingen door representerende centrale organisaties (werkgevers en vakbonden), intraprofessionele onderhandelingen (binnen eenzelfde professionele geleding), onderhandelingen binnen een specifiek kader (zoals binnen een multinationaal concern) en ongecoördineerde onderhandelingen. In plaats van coördinatie via de overheid dan wel de sociale partners, kan sprake zijn van marktwerking, waarbij onderhandelingen tussen een werkgever en individuele personen centraal staan (Friedman, 1970). In de praktijk spelen overheid, sociale partners en markt een rol in alle nationale systemen, maar hun relatieve gewicht verschilt sterk tussen landen (Traxler et al., 2001). In Nederland spelen sinds 1982 interprofessionele onderhandelingen door representerende centrale organisaties van werkgevers en werknemers de centrale rol in(loon)coördinatie, in samenhang met sectorale cao-onderhandelingen. De overheid blijft evenwel van groot belang en er is een toenemend gewicht van marktwerking.

\section{(Loon)coördinatie via doorwerking}

De (loon)coördinatie via kabinet, sociale partners en marktwerking sinds 1982 is gebaseerd op doorwerking. Doorwerking is een concept dat zowel een structuur als een afstemmingsproces omvat. Het startpunt voor doorwerking is een afspraak of aanbeveling die het kabinet en sociale partners op centraal niveau overeenkomen. Een centrale afspraak van het kabinet en/of de Stichting van de Arbeid wordt vervolgens naar de verschillende achterbannen van werkgevers en vakbonden vertaald op een zodanige manier dat er cao-afspraken over zijn te maken, die verder vorm krijgen in de bedrijven en organisaties. De centrale vakbonden maken de vertaalslag naar de aangesloten vakbonden respectievelijk de vakbondsbestuurders. De centrale werkgeversorganisaties vertalen op analoge wijze een afspraak naar de aangesloten werkgevers respectievelijk cao-onderhandelaars. Het voornoemde akkoord uit 1982 omvatte bijvoorbeeld de aanbeveling om tot arbeidstijdverkorting te komen en in veel ondernemingen is daarover indertijd een maatwerkafspraak in de cao gemaakt. Het sociaal akkoord uit 2013 bevatte onder andere de aanbeveling om mensen met een arbeidsbeperking aan de slag te helpen bij werkgevers in de marktsector en bij de overheid. Werkgeversvereniging AWVN heeft vervolgens met het 7500-banenplan een eerste vertaalslag gemaakt teneinde afspraken daarover in cao's te stimuleren, en het aantal toegezegde banen is eind 2015 bereikt. Het vertalen van een 
Figuur 9.1 Looncoördinatie via het proces van doorwerking

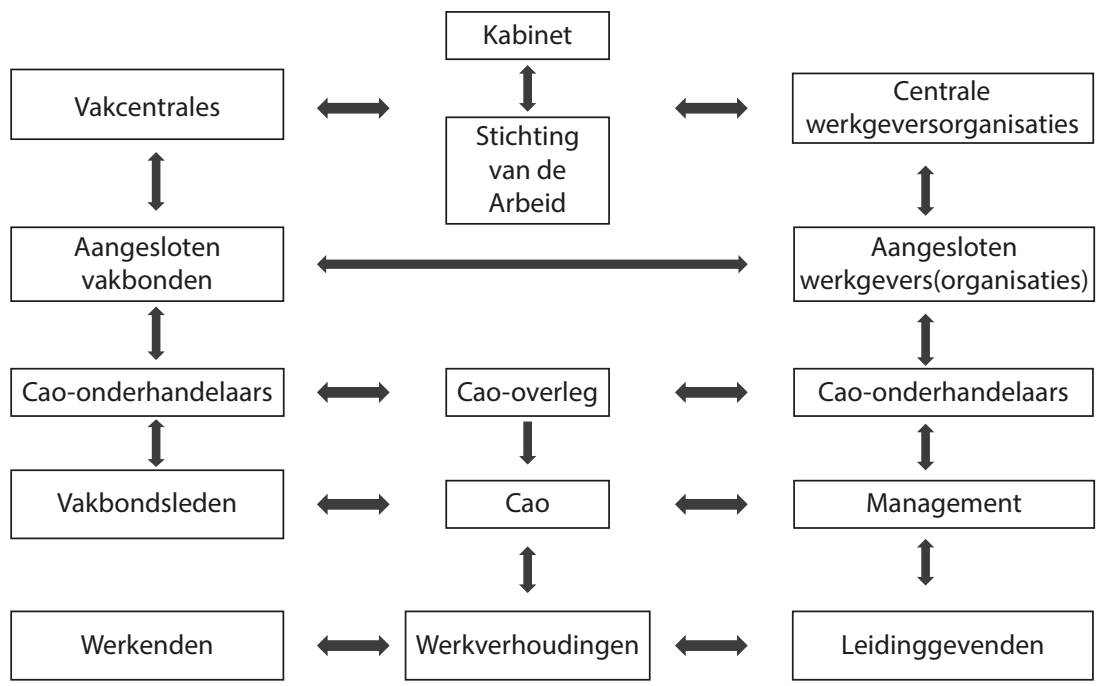

Naar Rojer, 2012

centrale aanbeveling naar het cao-niveau brengt een gelaagde structuur van de arbeidsverhoudingen met zich mee (Rojer, 2012). Figuur 9.1 beeldt dat uit.

Voor een succesvol proces van doorwerking moeten (i) robuuste centrale afspraken gemaakt kunnen worden, die vervolgens soepel doorwerken naar decentrale stakeholders; en moeten (ii) decentrale werkgevers en vakbonden hun particuliere belang dienen én tegelijkertijd compromissen sluiten die aansluiten bij de sociaaleconomische context en het algemeen belang (Rojer, 2012; Tros et al. 2006). Hieruit volgen vier voorwaarden die cruciaal zijn voor het functioneren van doorwerking:

a centrale beleidsruimte: het kabinet en sociale partners op centraal niveau moeten voldoende beleidsruimte hebben om afspraken te maken die ertoe doen. De toetsvraag voor de praktijk is of er op centraal niveau aanbevelingen zijn gedaan die loonvorming beïnvloeden;

b afstemming tussen centraal en het cao-niveau: stakeholders op centraal niveau en cao-niveau moeten elkaar gemakkelijk weten te vinden teneinde relevante sociaaleconomische thema's door te vertalen naar de achterban en de cao. De toetsvraag voor de praktijk is hoe de doorvertaling vorm heeft gekregen;

c vakbondsbereidheid: vakbonden moeten bereid en in staat zijn om over bredere sociaaleconomische thema's te onderhandelen met de 
werkgevers, naast de directe behartiging van de belangen van hun leden en de meer strategische ambities die een vakbeweging eigen zijn. De toetsvraag voor de praktijk is welke inzet de vakbonden hebben gepleegd;

d werkgeversbereidheid: ondernemingen moeten bereid en in staat zijn om naast het waarborgen van de continuïteit van de onderneming ook bij te dragen aan het bereiken van bredere sociale doelstellingen. De toetsvraag voor de praktijk is welke inzet werkgevers hebben gepleegd.

Voor doorwerking hoeft in een centrale afspraak overigens niet per se sprake te zijn van een loonafspraak. Ook als een centraal akkoord geen expliciete afspraak over loonvorming bevat, kan daar toch een temperend effect van uitgaan. Partijen aan de cao-tafel worden ook dan in de meeste gevallen geconfronteerd met onderwerpen die ten koste van de loonruimte kunnen gaan. Dat is ook onderdeel van de doorwerking van het macroniveau naar het niveau van de cao.

Het proces van doorwerking brengt uitwisseling van informatie met zich mee, die langs verschillende wegen verloopt. Het vertaalproces van een centrale afspraak naar het cao-niveau vereist namelijk dubbele regie (Axelrod, 1984). Allereerst is de rol van stille, interne coördinatie nodig om de eigen achterban ervan te overtuigen dat er meer is dan alleen het eigenbelang in het hier en nu. Stille coördinatie is tijdsintensief en vereist wederzijds vertrouwen in de arbeidsverhoudingen. De praktijk van de overlegeconomie kan alleen functioneren op basis van de kracht van overtuiging, ofwel sweet talk (McCloskey, 2007). Ten tweede is het nodig om via externe coördinatie breed in te zetten op kennistransfer en objectivering van stuurgegevens. Het is immers belangrijk dat de partijen aan weerszijden van de tafel bekend zijn met en kunnen vertrouwen op de gegevens die aan hun onderhandelingen ten grondslag liggen. Het instituut dat sinds 1982 een systematische rol in looncoördinatie heeft gespeeld, is het Centraal Planbureau (CPB). De vakbonden ontlenen aan de CPB-cijfers de berekening van hun looneis en loonruimte. De werkgevers baseren hun oordeel op de CPB-cijfers om vast te stellen in welke mate de Nederlandse economie al dan niet in de pas loopt met het buitenland. De overheid vaart erop voor haar macro-economisch beleid. De CPB-berekeningen hebben letterlijk een economisch kompas gevormd voor alle partijen (Becker en Hendriks, 2008). ${ }^{2}$

2 Ook werkgeversvereniging AWVN heeft stelselmatig informatie over arbeidsvoorwaarden(vorming) publiekelijk gedistribueerd (AWVN, 1996-2014) en heeft zich tot een betrouwbare openbare bron ontwikkeld. 
De dubbele regie op informatie vormt de smeerolie voor de samenhang tussen de vier genoemde voorwaarden van het stelsel van doorwerking.

\section{Doorwerking en de cao}

Het stelsel van doorwerking kan alleen meerwaarde voor partijen en de samenleving genereren als er sprake is van continuïteit in het afsluiten van cao's, bestuurskundig en qua aantal. Het SER-rapport 'Verbreding draagvlak cao-afspraken' (2013) concludeerde dat aan het bestaansrecht van de cao niet hoeft te worden getwijfeld, mits actief wordt gewerkt aan draagvlak. Mede naar aanleiding van het SER-advies heeft de minister van Sociale Zaken en Werkgelegenheid in een brief aan de voorzitter van de Tweede Kamer van 13 november 2015 verklaard dat het cao-stelsel van grote betekenis is voor de Nederlandse arbeidsverhoudingen. ${ }^{3}$ Bestuurskundig gezien is de cao dan ook vooralsnog toekomstbestendig. Voorts is de cao qua aantallen en dekking behoorlijk stabiel geweest in de afgelopen jaren (tabel 9.1). Het aantal ondernemingscao's is in de periode 2003-2015 met 3 procent licht gedaald, terwijl het aantal bedrijfstakcao's met 8 procent is afgenomen. Het aantal werknemers dat onder de werking van de cao valt, is in totaal met 4 procent afgenomen. Desondanks viel in 2015 zo'n 67 procent van de werkzame beroepsbevolking ${ }^{4}$ onder de werking van een cao (ter vergelijking: in 2003 was dat 74 procent). De nog steeds hoge dekkingsgraad is terug te voeren op een hoge organisatiegraad van werkgevers en de wettelijke binding van derden aan een collectieve arbeidsovereenkomst, de algemeenverbindendverklaring (avv). De avv is al langere tijd onderdeel van de Nederlandse discussie over de toekomst van de arbeidsverhoudingen, maar in de voornoemde brief van de minister geeft hij aan dat er geen aanleiding is om de regeling voor het algemeen verbindend verklaren van een cao voor een bedrijfstak te wijzigen.

Het stabiele beeld van de cao laat zich verklaren. Er zijn voor beide partijen veel voordelen aan verbonden: een gemeenschappelijk vertrekpunt (zoals CPB-ramingen en centrale aanbevelingen), arbeidsrust na overeenstemming over een vernieuwde cao (de cao is een peace contract), de mogelijkheid om af te wijken van wettelijke bepalingen (driekwart dwingend recht), draagvlak in de organisatie of branche door legitimering op basis van

3 Brief van de minister van Sociale Zaken en Werkgelegenheid no. 669 aan de voorzitter van de Tweede Kamer der Staten-Generaal. Den Haag, 13 november 2015.

4 De werkzame beroepsbevolking voor 2015 is berekend op grond van het CBS-cijfer van 2014 en de CPB-indicatie voor 2015. 
Tabel 9.1 Aantal (bedrijfstak)cao's naar aantal werknemers 2003-2015

\begin{tabular}{lcccccc}
\hline & \multicolumn{2}{c}{$\mathbf{2 0 0 3}$} & \multicolumn{2}{c}{2015} & \multicolumn{2}{c}{$\mathbf{2 0 0 3 - 2 0 1 5}$} \\
\cline { 2 - 7 } & $\begin{array}{c}\text { Aantal } \\
\text { cao's }\end{array}$ & $\begin{array}{c}\text { Aantal } \\
\text { werknemers } \\
(\mathbf{m} \mathbf{l})\end{array}$ & $\begin{array}{c}\text { Aantal } \\
\text { cao's }\end{array}$ & $\begin{array}{c}\text { Aantal } \\
\text { werkne- } \\
\text { mers (mln) }\end{array}$ & $\begin{array}{c}\text { Aantal } \\
\text { cao's }\end{array}$ & $\begin{array}{c}\text { Aantal } \\
\text { werknemers }\end{array}$ \\
\hline Ondernemingscao & 519 & 0,65 & 503 & 0,52 & $-3 \%$ & $-20 \%$ \\
Bedrijfstakcao & 193 & 5,12 & 177 & 4,96 & $-8 \%$ & $-3 \%$ \\
Totaal & 712 & 5,77 & 680 & 5,49 & $-4 \%$ & $-4 \%$ \\
\hline
\end{tabular}

Bron: Ministerie van Sociale zaken en Werkgelegenheid. Het totaal aantal cao's in Nederland is groter en omvat ook cao's over uiteenlopende onderwerpen van sociaal beleid, zoals pensioen.

een cao, de mogelijkheid tot een algemeenverbindendverklaring (alsmede de mogelijkheid tot dispensatie ervan onder voorwaarden) en de koppeling van de cao aan het individuele arbeidscontract (incorporatiebeding). Langs deze weg ontstaat er voor beide partijen tevens een besparing op transactiekosten. De werkgever hoeft immers niet afzonderlijk te onderhandelen met elk individu, en individuen worden niet tegen elkaar uitgespeeld. De genoemde voordelen tellen zwaar in vergelijking tot een alternatief als onderhandelen met een ondernemingsraad of pure marktwerking.

De solide bestuurskundige grondslag en de continuïteit in het aantal cao's betekent dat het proces van doorwerking relevant blijft.

\section{De Wassenaarperiode: uit de schaduw van de statelijke hiërarchie}

In het voorgaande zijn vier elementen onderscheiden die cruciaal zijn voor het functioneren van doorwerking: centrale beleidsruimte, afstemming tussen centraal en decentraal niveau, vakbondsbereidheid en werkgeversbereidheid. Hier worden deze elementen besproken voor de periode 1982-1999 om vervolgens de respectievelijke uitkomsten te bespreken.

\section{Aanbevelingen op centraal niveau zetten de toon}

De economie belandde in het begin van jaren 80 op een dieptepunt. In die zin was het Akkoord van Wassenaar een echte mijlpaal: partijen herbevestigden de noodzaak om de golven van de economie als vertrekpunt voor cao-onderhandelingen te nemen. Het akkoord van 1982 kwam echter vooral bekend te staan als een werkgelegenheidsakkoord. Gegeven de indertijd belabberde staat van de economie, waren partijen het eens over 
Tabel 9.2 Typering van de (loon)coördinatie via centrale akkoorden in de periode 1982-1999

\begin{tabular}{|c|c|c|}
\hline Jaar & Akkoord & Typering van de (loon)coördinatie \\
\hline 1982 & $\begin{array}{l}\text { Tripartiete "Akkoord van Wassenaar", } \\
\text { in verband met de verslechterende } \\
\text { economie en oplopende werkloosheid. }\end{array}$ & $\begin{array}{l}\text { De loonmatiging in ruil voor arbeidstijd- } \\
\text { verkorting werd afgedwongen onder } \\
\text { dreiging van ingrijpen door de overheid. }\end{array}$ \\
\hline 1989 & $\begin{array}{l}\text { Tripartiete "Gemeenschappelijk } \\
\text { Meerjaren Beleidskader" (GBK) ten } \\
\text { behoeve van duurzame groei, groei van } \\
\text { de werkgelegenheid en daling van de } \\
\text { werkloosheid. }\end{array}$ & $\begin{array}{l}\text { Kabinet en sociale partners roepen op } \\
\text { tot activerend arbeidsmarktbeleid en } \\
\text { gematigde loonkostenontwikkeling } \\
\text { en stabilisering van de collectieve } \\
\text { lastendruk. }\end{array}$ \\
\hline 1993 & $\begin{array}{l}\text { Bipartiete akkoord "Een nieuwe koers" } \\
\text { van de Stichting van de Arbeid, omdat } \\
\text { de werkloosheid structureel toenam en } \\
\text { partijen de remweg tot loonmatiging te } \\
\text { lang vonden. Het akkoord was bedoeld } \\
\text { als agenda voor decentrale partijen. }\end{array}$ & $\begin{array}{l}\text { Loonmatiging via een globale cen- } \\
\text { trale afspraak en decentraal maatwerk. } \\
\text { Hiermee werden decentrale cao- } \\
\text { onderhandelingen gestimuleerd. }\end{array}$ \\
\hline 1995 & $\begin{array}{l}\text { Bipartiete "Verklaring arbeidsvoorwaar- } \\
\text { denoverleg 1996" als verdere uitwerking } \\
\text { van het akkoord "Een nieuwe koers" en } \\
\text { ter verbetering van het perspectief van } \\
\text { de (onderkant van de) arbeidsmarkt. }\end{array}$ & $\begin{array}{l}\text { De noodzaak tot loonmatiging wordt } \\
\text { herbevestigd. De collectieve vorming } \\
\text { van arbeidsvoorwaarden blijft betekenis } \\
\text { houden en het belang van maatwerk } \\
\text { wordt groter. }\end{array}$ \\
\hline 1996 & $\begin{array}{l}\text { Bipartiete "Flexakkoord" van de } \\
\text { Stichting van de Arbeid, ten behoeve } \\
\text { van meer flexibiliteit voor zittend per- } \\
\text { soneel en meer zekerheid voor flexibel } \\
\text { personeel. }\end{array}$ & $\begin{array}{l}\text { Het unanieme akkoord was de basis } \\
\text { voor de invoering van de Wet Flexibi- } \\
\text { liteit en Zekerheid (1999). Het akkoord } \\
\text { bevat geen afspraak over loonkosten. }\end{array}$ \\
\hline 1997 & $\begin{array}{l}\text { Bipartiete "Agenda } 2002 \text { " van de } \\
\text { Stichting van de Arbeid, als vervolg op } \\
\text { "Een nieuwe koers". }\end{array}$ & $\begin{array}{l}\text { Voortzetten decentralisatiebeleid } \\
\text { van de arbeidsvoorwaardenvorming } \\
\text { met maatwerk in ondernemingen en } \\
\text { binnen het kader van een verantwoorde } \\
\text { loonkostenontwikkeling en thema's } \\
\text { zoals belonen, scholing, loonbaanbege- } \\
\text { leiding, zorg, ouderenbeleid, pensioen. }\end{array}$ \\
\hline 1999 & $\begin{array}{l}\text { Kabinet en sociale partners herbeves- } \\
\text { tigen de afspraken over "Agenda 2002" } \\
\text { voor } 2000 \text { en 2001; } \\
\text { Bipartiete verklaring van de Stichting } \\
\text { van de Arbeid ten behoeve van het } \\
\text { arbeidsvoorwaardenoverleg 2000/2001. }\end{array}$ & $\begin{array}{l}\text { Sociale partners in de Stichting stellen } \\
\text { vast dat een verantwoorde loonkosten- } \\
\text { ontwikkeling nog steeds uitgangspunt } \\
\text { is voor arbeidsvoorwaardenbeleid. De } \\
\text { Stichting van de Arbeid roept cao- } \\
\text { partijen op om hun overleg te blijven } \\
\text { baseren op de "Agenda 2002". }\end{array}$ \\
\hline
\end{tabular}

de noodzaak om de werkgelegenheid een impuls te geven. Het toenmalige centrale akkoord was een weerslag van de coördinatie van de economische én sociale belangen van onze samenleving. Gedurende de jaren 80 en 90 heeft op centraal niveau een reeks van aanbevelingen de toon gezet voor 
decentrale cao-onderhandelingen (Touwen, 2014; Visser en Hemerijck, 1997). De typering van de (loon)coördinatie in centrale akkoorden in de periode 1982-1999 is weergegeven in tabel 9.2.

De serie centrale aanbevelingen was in verschillende opzichten richtinggevend voor het cao-overleg. Allereerst waren de aanbevelingen steevast gericht op het beheersen van de loonkosten. Tegelijkertijd werden de aanbevelingen gebruikt om de decentralisatie gestalte te geven en maatwerk per onderneming of branche te stimuleren. Maatwerk kon ontstaan doordat naast de loonvorming ook kwalitatieve thema's op de cao-agenda kwamen, zoals rond arbeidsmarkt, gezondheid, sociale zekerheid of pensioen.

Wat de overheid na 1982 resteerde, was om via zachte coördinatie, zoals een centrale aanbeveling met sociale partners, invloed uit te oefenen. Daarnaast bleef de overheid de hoeder van de institutionele structuur (Hodgson, 2006) waarin de doorwerking bleef ingebed, zoals de relevante wetgeving, adviesorganen en overlegmomenten. Diezelfde overheid heeft overigens in de jaren 90 ook de marktwerking op tal van fronten gestimuleerd (WRR, 2012b). Onderdeel van die beweging was het opdelen van het centrale overleg over arbeidsvoorwaarden bij de overheid in acht sectoren in 1993 en een golf van privatisering van overheidsdiensten. In deze periode heeft het bij de overheid - en in de marktsector - uitgewerkt als een signaal dat de bakens verzet gingen worden. De loonontwikkeling van de overheid blijft in deze bijdrage overigens buiten beschouwing, mede omdat de overheidslonen de loonvorming in de marktsector volgen (CPB, 2014c).

\section{Doorwerking naar decentraal niveau wordt routine}

In deze periode hebben decentrale vakbonden en werkgevers(organisaties) het vermogen ontwikkeld om centrale aanbevelingen te vertalen naar caoafspraken. Dat was niet vanzelfsprekend. Zo waren in 1982 werkgevers bepaald niet meteen ontvankelijk voor afspraken over arbeidstijdverkorting (Buitelaar en Van den Toren, 1999). De maat voor mannen en vrouwen was toen nog de voltijdsbaan. In deze periode ontwikkelde zich de interprofessionele onderhandelvaardigheid bij zowel werkgevers als vakbonden. Het proces van doorvertalen van een centrale aanbeveling naar het cao-niveau kwam schoksgewijs van de grond. Zo werd het tripartiete 'Gemeenschappelijk Meerjaren Beleidskader' (tabel 9.2) van 1989 in de praktijk als technocratisch ervaren. In 1991 kwam de tripartiete overlegeconomie zelfs letterlijk even tot stilstand 'toen werkgevers in maart aankondigden geen heil meer te zien in het (meer)jaarlijkse tripartiete overleg met tientallen deelnemers, een oeverloze agenda en meestal weinig concrete resultaten' 
(Van den Braak, 2014, p. 20). Als vernieuwende beweging werd een reeks bipartiete akkoorden in de Stichting van de Arbeid afgesloten, met als mijlpaal het akkoord 'Een nieuwe koers' van 1993 (tabel 9.2). Met dit laatste akkoord namen sociale partners de facto zelf de verantwoordelijkheid voor het sturen van het arbeidsvoorwaardenbeleid. Van werkgeverszijde werden verschillende criteria gehanteerd om de verhouding tussen centraal en decentraal te beïnvloeden (Bout, 1999), zoals de juiste (machts)balans om de onderhandeling te voeren, waar het goede expertiseniveau zat, op welk onderhandelingsniveau men het beste een en ander kon overzien en waar de mogelijkheden het grootst waren voor daadwerkelijke effectieve uitvoering. Arbeidstijden zouden bijvoorbeeld het beste op de werkplek zelf zijn te regelen, terwijl pensioen juist een hoog niveau van onderhandelen zou vergen.

Gedurende deze periode dienden zich enkele dominante thema's aan die zich goed leenden voor doorwerking. Een van die thema's was bijvoorbeeld inzetbaarheid. Mede door de globalisering en versneld door enkele fusiegolven groeide het aantal multinationale ondernemingen in rap tempo. De toch al open Nederlandse economie dynamiseerde. Nieuwe (digitale) kennis drong voor op langdurige werkervaring en noodzaakte werkgevers tot het herinrichten van werkprocessen. Medewerkers kregen er belang bij om de ontstane onzekerheid over hun arbeidsperspectief te beheersen. Het concept van een dienstverband voor het leven (life time employment) maakte in de jaren 90 in snel tempo plaats voor een grotere individuele verantwoordelijkheid van de medewerker voor de eigen inzetbaarheid (Verhoeff, 2007). Ontwikkeling in het werk en 'een leven lang leren' kwamen op de cao-agenda. Het leidde ertoe dat eind jaren go in vrijwel alle cao's afspraken waren gemaakt over inzetbaarheid. Het vertrouwen bij de achterbannen van werkgevers en vakbonden in doorwerking groeide; zo ontstond een social licence to operate (Wilburn en Wilburn, 2011).

\section{Voor vakbonden is loonruimte leidend}

Centraal stonden de vakbonden er in de jaren 80 qua positie en invloed niet goed voor, maar dit werd in de jaren go beter. Met name de (indertijd nog) FNV vakcentrale (heden FNV in Beweging, hierna voor de eenvoud: FNV), heeft vanaf 1994 de samenhang tussen het macroniveau en het cao-niveau opgehard door het invoeren van een voorgeschreven maximumlooneis (Rojer en Harteveld, 2002). Gewoonlijk werd - en wordt nog steeds - als leidraad genomen de som van de stijging van de arbeidsproductiviteit en de producentenprijzen. Daarmee gaf de FNV aan de economische gang 
van zaken als vertrekpunt te nemen. Als ondergrens gold de stijging van de geschoonde consumentenprijsindex (inflatie laag, geschoond voor de invloed van overheidsmaatregelen). Daarnaast keek de FNV per jaar naar de algemene economische (toekomstige) gang van zaken. De maximumlooneis was aanvankelijk ontstaan om de interne spanning tussen markt-en overheidsbonden binnen de FNV te beheersen. Naarmate de differentiatie tussen marktsectoren toenam, kreeg de maximumlooneis meer betekenis in de externe looncoördinatie. De looneis omvatte zowel een structurele looncomponent als ruimte voor kwalitatieve thema's. Daarmee kreeg de FNV vakcentrale via de aangesloten sectorale vakbonden brede invloed op de cao-agenda. Het gaf de mogelijkheid om mee te bewegen met zwakke sectoren en met sectoren waar meer was te eisen. Daartoe ging de FNV jaarlijks coördineren op een aantal sleutelcao's. De andere vakbonden hanteerden formeel weliswaar niet een maximumlooneis, maar zaten qua strategie veelal wel in de nabijheid van de FNV-benadering.

\section{De cao als onderdeel van een cyclus sociaal beleid}

Vanaf 1982 werden onder werkgevers de onderwerpen voor de cao-agenda 'enerzijds bepaald via nationale discussies in de Sociaal-Economische Raad en de Stichting van de Arbeid en anderzijds langs de lijnen van hetgeen in de branche of het bedrijf als passend wordt gevoeld' (Bout, 1999, p. 14). Bout, indertijd directeur arbeidsvoorwaardenbeleid van werkgeversvereniging AWVN, stelde vast dat 'als onderhandelingen in bedrijven en bedrijfstakken niet goed aansluiten bij de nagestreefde sociaaleconomische richting, de beleidsvoering op nationaal niveau letterlijk in de lucht hangt. Door een wederzijds actief samenspel van de betrokkenen op alle niveaus, nationaal, bedrijfstak- en bedrijfsgewijs, wordt het gewenste beleid gemaakt en uitgevoerd' (Bout, 1999, p. 12). In deze periode kwam onder veel werkgevers (in branches en bedrijven) een jaarlijkse cyclus op gang met een centrale arbeidsvoorwaardennota als start, gevolgd door een reeks bijeenkomsten ter voorbereiding van het volgende onderhandelingsseizoen, vervolgens de cao-onderhandelingen zelf en uiteindelijk een evaluatie. Een arbeidsvoorwaardennota bevatte zowel elementen voor loonbeheersing als sociaaleconomische thema's. In deze beleidscyclus hebben werkgevers altijd gestuurd op maatwerk in ondernemingen en hielden ze afstand van een begrip als loonruimte. Dat de strakke centrale sturing van werkgevers geleidelijk aan werd losgelaten, illustreert de opheffing in 1996 van de landelijke Onderlinge Werkgevers Garantieregeling, het voor werkgevers belangrijke coördinatie-instrument bij stakingen (de Volkskrant, 1996). 
Ondernemingen kregen er in de jaren 90 belang bij om de cao mee te laten ademen met de dynamiek van de afzetmarkt. Zij moesten flexibeler in de afzetmarkt gaan opereren. De traditionele hiërarchische organisatieinrichting maakte plaats voor interne decentralisatie. De positionering van functies en de ontwikkeling van de arbeidsvoorwaarden bleven geen 'apartje' meer, maar werden onderdeel van het bedrijfsbeleid (AWVN, 2004). Functiewaardering - de grondslag voor de redelijke beloningsverhoudingen in een organisatie - kwam in het teken te staan van de bedrijfsdoelen, en de cao werd een tool of management. Het bracht met zich mee dat individuele werkgevers gaandeweg zelf de cao-agenda gingen bepalen als onderdeel van een cyclus sociaal beleid, in plaats van te wachten op de voorstellenbrieven van de vakbonden. Ook dan was er sprake van een mix van onderwerpen die het bedrijfsbelang raakten en sociaaleconomische onderwerpen. De via AWVN verspreide cao-informatie bood bedrijven de mogelijkheid om relatieve onderlinge posities te vergelijken en desgewenst de timing van onderhandelingen in het cao-seizoen enigszins te beïnvloeden.

\section{Resultaten van de periode tot 2000}

De doorwerking in de periode tot 2000 is geëvalueerd op basis van de beschreven activiteiten van partijen in het proces van doorwerking, de loonontwikkeling (output) en de resultaten voor de samenleving (outcome).

De activiteiten van partijen hebben stelselmatig in het teken gestaan van het proces van doorwerking. Het krachtenveld van partijen op centraal niveau heeft een serie aanbevelingen opgeleverd, die achtereenvolgens steeds de noodzaak tot loonkostenmatiging hebben bevestigd. Minstens even belangrijk is dat de aanbevelingen het ontwikkelen van een decentrale onderhandelroutine hebben gestimuleerd. Tevens hebben zowel werkgeversorganisaties als vakbonden actief gewerkt aan het doorvertalen van een centrale aanbeveling naar het cao-niveau. Een en ander ging op gezette tijden gepaard met flinke onderlinge verschillen van inzicht, zowel op centraal niveau als op cao-niveau, die vervolgens via compromissen werden opgelost. Dat polderen maakte het mogelijk om ingrijpende veranderingen in de sociaaleconomische structuur door te voeren. De resultaten van de loonontwikkeling in de periode 1982-1999 zijn weergegeven in figuur 9.2. Voor een duiding van de resultaten van doorwerking in loonontwikkeling wordt uitgegaan van de looneis van de FNV. Vanaf 1994 heeft de FNV jaarlijks ingezet op een maximumlooneis (zie hiervoor). In figuur 9.2 is de looneis van de FNV afgezet tegen de ontwikkeling van de cao-lonen en de inflatie (afgeleid). Over het algemeen zullen de cao-lonen zich jaarlijks bewegen 
Figuur 9.2 Ontwikkeling in cao-lonen, inflatie afgeleid en maximumlooneis FNV (vanaf 1994) in de periode 1982-1999

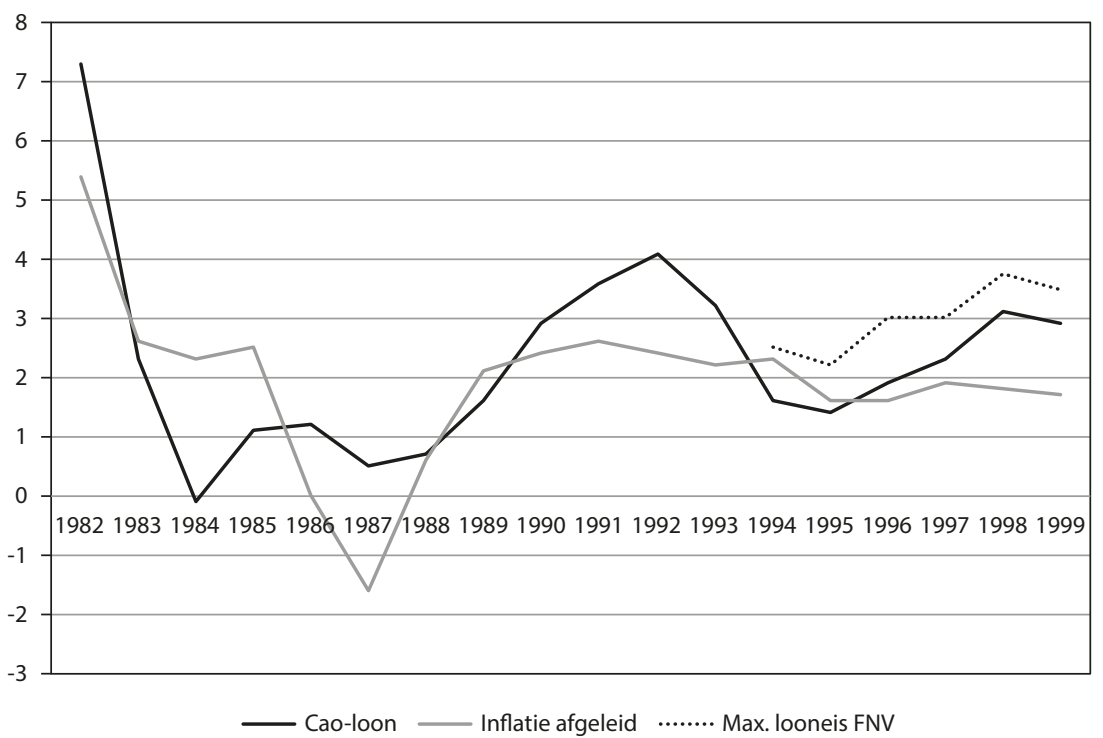

tussen de inflatie en de looneis van de vakbonden. Dat is tussen 1996 en 1999 het geval, terwijl de lonen in de periode ervoor stabiliseerden na forse schommelingen. In deze Wassenaarse periode was gemiddeld genomen sprake van een gematigde loonontwikkeling (Rojer en Harteveld, 2002; De Beer, 2013).

De cao is gaande deze periode breder geworden, en naast afspraken over geld en tijd andere onderwerpen gaan bestrijken - met name op het gebied van arbeidsomstandigheden, gezondheid en inzetbaarheid (AWVN, 1996-2014). Het aantal stakingen bleeflaag (Smit, 2013). In deze periode zijn sociale partners uit de schaduw van de statelijke hiërarchie van voor 1982 gestapt. De doorwerking van centrale aanbevelingen naar het cao-niveau heeft zich ontwikkeld tot een succesvolle routine. Een routine die was gebaseerd op interprofessionele onderhandelingen tussen werkgevers(organisaties) en vakbonden, en een overleg- en informatiestructuur die het proces van afstemming naar de achterban faciliteerde.

Bovenstaande uitkomsten gingen gepaard met positieve resultaten voor de samenleving. De economische groei was bestendig en de werkgelegenheid groeide gestaag (Visser en Hemerijck, 1997; De Beer, 2013). Voor deze periode heeft het proces van doorwerking dan ook zeker bijgedragen aan het maatschappelijk belang van economische voorspoed en maatschappelijke rust. 


\section{De ontwikkeling van doorwerking na 2000}

De vier voorwaarden die cruciaal zijn voor doorwerking worden nu beschreven voor de periode 2000-2015: centrale beleidsruimte, afstemming tussen centraal en decentraal niveau, vakbondsbereidheid en werkgeversbereidheid. Daarna volgt de bespreking van de uitkomsten.

\section{Afnemend coördinatievermogen op centraal niveau}

Sinds eind jaren 90 kreeg de landelijke politiek te maken met smallere beleidsmarges als lidstaat van de EU, waar steeds meer op Europees niveau wordt bepaald (Keune en Marginson, 2013). Na de crisis van 2008 bleken de Europese lidstaten bovendien zorgwekkend sterk afhankelijk te zijn geworden van de financiële markten (Streeck, 2015). Voorts heeft de Nederlandse regering in de periode na 2000 veel arbeidsmarkt-gerelateerde taken naar gemeentes afgestoten. De slagvaardigheid van het kabinet op macroniveau nam daardoor af. De arbeidsmarkt is uit de aard der zaak regionaal georiënteerd, maar cao's zijn sectoraal van aard. De beweging naar decentralisatie maakte de uitvoering van bijvoorbeeld afspraken in een branche-cao over het plaatsen van werkzoekenden er niet eenvoudiger op. Het onstabiele politiek-maatschappelijke panorama versterkte het besef van de smalle marges om op macroniveau te sturen (zie Hemerijck en Van der Meer, elders in deze uitgave). Toch heeft het kabinet nog één keer fors ingegrepen in de loonontwikkeling, namelijk toen de economie rond 2002 terugviel. In 2003 besloot het kabinet, met instemming van sociale partners, dat voor 2004 de nullijn in contractlonen (niet: cao-lonen) zou gelden en voor 2005 een 'tot nul naderend' niveau (tabel 9.3). Deze unieke gebeurtenis in de polderhistorie was een poging om de lonen te beheersen volgens de 'ouderwetse' statelijke controle (Traxler et al., 2001) van ruim voor 1982.

De centrale vakbonden hebben het in deze periode regelmatig lastig gehad. Te beginnen met de organisatiegraad, die ook in deze periode een dalende lijn laat zien (zie De Beer, elders in deze uitgave). De vraag - die overigens niet alleen de vakbeweging zal bezighouden - is wat op langere termijn de minimale organisatiegraad is die nodig is om als gesprekspartner op centraal niveau geloofwaardig te blijven. De positie van de vakbonden laat zich illustreren aan de hand van de volgende twee voorbeelden. Allereerst hadden de turbulente ontwikkelingen op het politieke strijdtoneel van 2002 en 2003 (de wisseling van kabinet-Balkenende I naar II) de legitimiteit van de vakbonden danig verzwakt. De linkse politieke partijen waren namelijk verdeeld geraakt en kregen minder invloed. Het 
moeizaam gesloten najaarsakkoord van 2003 bleek feitelijk van weinig waarde toen het kabinet en de vakbonden het in het voorjaar van 2004 niet eens werden over vervroegde uittreding en pensionering. De regering volgde in de escalerende maanden erna een eigen koers. Met het massale en historische protest over het beoogde pensioenakkoord op het Museumplein van oktober 2004 kregen de vakbonden echter hun onderhandelingspositie in het centrale overleg weer terug, inclusief hun invloed op de nationale agenda. Het kabinet had de eigen hand overspeeld. Het woord loonmatiging werd een beleidsmatig beladen begrip en werd gaandeweg vervangen door uitdrukkingen als 'verantwoorde ontwikkeling van de arbeidsvoorwaarden'. Het daaropvolgende centrale akkoord van 2009 rept met een enkele zin van loonrealisatie die voor allen gedifferentieerd en bescheiden zal zijn. Het tweede voorbeeld betreft het tripartiete sociaal akkoord van 2013, dat overigens geen expliciete verwijzing naar loonmatiging bevatte. In het sociaal akkoord van 2013 waren veel onderwerpen opgenomen die op de agenda van de vakbeweging stonden. Met name voor de FNV, die zich midden in het venijnig proces van interne heroriëntatie bevond, bood het akkoord positioneel een perspectief. Deze keer hadden de werkgevers reden tot klagen, met onder andere de lastig uitvoerbare aanpassingen in het ontslagrecht, de afspraak over een derde $\mathrm{WW}$-jaar en een dreigend quotum tot het plaatsen van arbeidsgehandicapten. Het feit dat het akkoord er kwam, was - gegeven het krachtenveld - belangrijker dan de inhoud (Verhoeff en De Bruin, 2013).

De beleidsruimte voor de centrale werkgevers kwam in deze periode onder druk te staan. Zij moesten hun krachten bundelen, wat resulteerde in de toenadering van VNO-NCW, AWVN en MKB-Nederland (VNO-NCW, 2000-2014; Van den Braak, 2014). Ook hebben branches het moeilijker gekregen: de laatste jaren moest steeds meer moeite worden gedaan om het draagvlak voor bijvoorbeeld algemeenverbindendverklaring te verkrijgen. Tegelijkertijd bleef op centraal niveau de verwachting bestaan dat branches maatschappelijk relevante thema's doorvertalen naar de bij hen aangesloten werkgevers. Daarnaast waren er geluiden uit de achterban van werkgevers die wijzen op onvrede met de voorbereiding, besluitvorming en uitvoerbaarheid van centrale aanbevelingen (de Volkskrant, 2012). Werkgevers hadden hun representativiteit qua omvang op orde (zie De Beer, elders in deze uitgave), al zijn er enkele kanttekeningen te plaatsen. Zo is in deze periode de invloed van de Angelsaksische bedrijfscultuur groter geworden (SER, 2012). De daaruit voortvloeiende grotere pluriformiteit brengt het risico met zich mee dat de organisatiegraad van werkgevers barsten gaat vertonen, terwijl een hoge organisatiegraad van werkgevers cruciaal is 
voor het voortbestaan van de cao (De Beer, 2013). Voorts moeten, meer dan het vanzelfsprekende draagvlak dat vakbonden in de samenleving hebben, werkgevers hun sociaal paspoort blijven verdienen (Wilburn en Wilburn, 2011). Verschillende soorten incidenten illustreren dat. Rond de eeuwwisseling constateert bijvoorbeeld Herkströter, hoogleraar en voormalig topman van Shell, dat de license to operate van ondernemingen aan herziening toe is (Herkströter en De Graaf, 2002). Dit als gevolg van een reeks incidenten in corporate responsibility bij met name multinationals. Sinds 2000 hebben zich ook bij organisaties in de semi-overheid breed uitgemeten incidenten voorgedaan. De nasleep van de financiële rampspoed van 2008 bracht een reeks aan incidenten over de hoge beloning van bestuurders in de marktsector en overigens ook in de (semi-)overheid met zich mee. Het leidde ertoe dat het concept van corporate responsibility in het publieke debat naast de financiële verantwoording een extra betekenis kreeg: die van maatschappelijk verantwoord ondernemen. Meer recent werd, waar maatschappelijk verantwoord ondernemen in de vorige eeuw nog alleen de associatie had met 'groen', nu de verbinding gelegd met de P van people: de menselijke maat doet er (weer) toe. Ondernemingen maken deel uit van de samenleving en uitgaande van winstvermogen zou het bestaansrecht van bedrijven voor de toekomst vooral liggen in het toevoegen van sociaalmaatschappelijke waarde. Bij dit laatste lag voor AWVN het aangrijpingspunt voor hun pleidooi om wederom de licence to operate van ondernemingen te vernieuwen (AWVN, 2014; Verhoeff en Van der Steen, 2015).

Voor sommigen betekende de gang van zaken rond het sociaal akkoord in 2013 dat de tripartiete looncoördinatie op centraal niveau defınitief voorbij is. Immers, nadat het kabinet aan het begin van deze periode de loonvorming naar zich toe trok, werd na de crisis juist veel ruimte gelaten aan sociale partners. Het is maar de vraag of het kabinet afstand tot (loon)coördinatie blijft houden. De sociaaleconomische situatie was na 2008 zodanig urgent dat cao-partijen zelf hun verantwoordelijkheid inzagen, terwijl partijen op centraal niveau werden geconfronteerd met andere zaken die veel complexer waren. De typering van de (loon)coördinatie in centrale akkoorden in de periode $2000-2015$ is weergegeven in tabel 9.3. 
Tabel 9.3 Typering van de (loon)coördinatie via centrale aanbevelingen in de periode 2000-2015

\begin{tabular}{|c|c|c|}
\hline Jaar & Centrale aanbeveling & Typering van de (loon)coördinatie \\
\hline 2001 & $\begin{array}{l}\text { Bipartiet akkoord "Er is meer nodig" van } \\
\text { de Stichting van de Arbeid. }\end{array}$ & $\begin{array}{l}\text { De coördinatie is gericht op het } \\
\text { beheersen van een dreigende loon- } \\
\text { prijsspiraal, in verband met opwaartse } \\
\text { druk op de lonen als gevolg van krapte } \\
\text { op de arbeidsmarkt. }\end{array}$ \\
\hline 2002 & $\begin{array}{l}\text { Tripartiet Najaarsakkoord om de lonen } \\
\text { te matigen tot een maximum van } 2,5 \% \text {. }\end{array}$ & $\begin{array}{l}\text { De coördinatie wordt versterkt na de } \\
\text { stevige structurele stijging van de cao- } \\
\text { lonen in } 2001 \text { en gelijktijdige opwaartse } \\
\text { beweging van de incidentele loonont- } \\
\text { wikkeling (het totaal aan individuele } \\
\text { stijgingen in loonschalen). }\end{array}$ \\
\hline 2003 & $\begin{array}{l}\text { Tripartiet Najaarsakkoord over } \\
\text { bevriezing van de lonen in } 2004 \text { en een } \\
\text { 'tot nul naderend' niveau voor } 2005 \text {. }\end{array}$ & $\begin{array}{l}\text { Partijen worden ingehaald door } \\
\text { snel verslechterende economische } \\
\text { omstandigheden. } \\
\text { Het kabinet grijpt zelf fors in op de } \\
\text { loonontwikkeling (op de feitelijke } \\
\text { contractlonen, niet op de cao-lonen) op } \\
\text { een wijze zoals de staat dat voor } 1982 \\
\text { gewend was. }\end{array}$ \\
\hline 2004 & $\begin{array}{l}\text { In het voorjaar van } 2004 \text { worden het } \\
\text { kabinet en de vakbonden het niet eens } \\
\text { over de uitwerking van de voornemens } \\
\text { over (pre)pensioen. }\end{array}$ & $\begin{array}{l}\text { In het najaar van } 2004 \text { volgt een } \\
\text { massale protest op het museumplein, } \\
\text { dat de grond voor het beoogde akkoord } \\
\text { wegneemt. De vakbonden krijgen hun } \\
\text { coördinatievermogen in het centrale } \\
\text { overleg weer terug. }\end{array}$ \\
\hline 2008 & $\begin{array}{l}\text { Tripartiet akkoord "Samen doen wat } \\
\text { mogelijk is" (oktober 2008). }\end{array}$ & $\begin{array}{l}\text { De coördinatie is gericht op een verant- } \\
\text { woorde loonkostenontwikkeling om } \\
\text { een loon-en prijsspiraal te voorkomen. } \\
\text { Enkele weken later luidt het faillissement } \\
\text { van de bank Lehman Brothers in de VS } \\
\text { de financiële crisis in. }\end{array}$ \\
\hline 2009 & $\begin{array}{l}\text { Tripartiet Voorjaarsakkoord naar } \\
\text { aanleiding van de financiële crisis }\end{array}$ & $\begin{array}{l}\text { Vijf maanden na het uitbreken van } \\
\text { de crisis krijgt de coördinatie gestalte } \\
\text { met een globale afspraak over hoe te } \\
\text { reageren op de crisis, met een algemene } \\
\text { duiding dat de loonrealisatie voor } \\
\text { allen gedifferentieerd en bescheiden } \\
\text { zal zijn. In een recordtijd ontstaat een } \\
\text { trendbreuk in de ontwikkeling van } \\
\text { de cao-lonen, die sterk naar beneden } \\
\text { ombuigen van een jaargemiddelde van } \\
2,7 \% \text { naar } 1,3 \% \text {. }\end{array}$ \\
\hline
\end{tabular}




\begin{tabular}{|c|c|c|}
\hline Jaar & Centrale aanbeveling & Typering van de (loon)coördinatie \\
\hline 2010 & Bipartiet Pensioenakkoord & $\begin{array}{l}\text { Na een lang slepende discussie } \\
\text { worden partijen het eens over } \\
\text { aanpassingen in het pensioenstelsel. } \\
\text { Pensioen is nauw verweven met de } \\
\text { arbeidsvoorwaardenvorming. }\end{array}$ \\
\hline 2013 & $\begin{array}{l}\text { Tripartiet Sociaal akkoord (ook wel } \\
\text { aangeduid met het Mondriaan-akkoord) } \\
\text { met een veelheid van afspraken, mede } \\
\text { ter afsluiting van slepende kwesties. }\end{array}$ & $\begin{array}{l}\text { De coördinatie richt zich op een serie } \\
\text { onderwerpen, met name beperking van } \\
\text { de externe flexibiliteit op de arbeids- } \\
\text { markt, aanpassing van het ontslagrecht, } \\
\text { beperking van de WW en een quotum } \\
\text { over het plaatsen van arbeidsgehandi- } \\
\text { capten indien werkgevers er niet zelf in } \\
\text { slagen om in voldoende mate personen } \\
\text { uit deze doelgroep te plaatsen. Het } \\
\text { akkoord dat in kleine kring is gesloten } \\
\text { brengt voor cao-partijen tal van } \\
\text { uitwerkingsproblemen met zich mee. } \\
\text { Het akkoord bevat geen loonafspraak, } \\
\text { maar cao-partijen beseffen zelf de ernst } \\
\text { van de economische situatie maar al te } \\
\text { goed en handelen adequaat. }\end{array}$ \\
\hline
\end{tabular}

Buiten het overzicht gelaten zijn de akkoorden van de Stichting van de Arbeid, die nadrukkelijk arbeidsmarkt-gerelateerd waren. Zoals eerder aangegeven kan van zo'n akkoord, ondanks het ontbreken van een loonafspraak, ook een temperend effect op de loonontwikkeling uitgaan.

Deze schets illustreert hoezeer het vermogen tot coördinatie op macroniveau op de proef is gesteld. Een kabinet kan niet meer geruisloos besturen. De vakbonden staan voor een ingewikkeld vraagstuk qua positionering. En werkgevers sluiten niet meer vanzelf aan bij de belangen van de BV Nederland.

\section{Toenemende afstand tussen centraal en decentraal niveau}

De smalle marges voor (loon)coördinatie op macroniveau voor kabinet en sociale partners zouden bestuurlijke behoedzaamheid doen vermoeden. Daartoe hoort onder andere een tijdige consultatie van decentrale partijen, voorafgaand aan besluitvorming of het faciliteren van de uitwerking van een centrale aanbeveling. Het tegendeel gebeurde bij belangrijke momenten. Het debat over het beoogde pensioenakkoord in 2004 moest bijvoorbeeld worden afgedwongen via de demonstratie op het Museumplein. Daarmee was het dossier van de oudedagsvoorziening nog lang niet gesloten. Bij de AOW-perikelen van 2009 verloren de centrale vakbonden de instemming 
Tabel 9.4 Illustratie van de inzet van werkgevers en vakbonden in het caoseizoen 2014

\begin{tabular}{|c|c|c|}
\hline & Speerpunten AWVN & Geen (directe) speerpunten AWVN \\
\hline Speerpunten FNV & $\begin{array}{l}\text { - Duurzame inzetbaarheid } \\
\text { (scholing, van werk naar } \\
\text { werk, levensfasebewust } \\
\text { personeelsbeleid) } \\
\text { - Participatie (instroom van } \\
\text { wajongeren, jongeren, } \\
\text { ouderen) } \\
\text { - implementatie Sociaal } \\
\text { akkoord }\end{array}$ & $\begin{array}{l}\text { - Activerend vakbondswerk } \\
\text { (ledenbetrokkenheid) } \\
\text { - Koopkrachtbehoud (looneis 3\%) } \\
\text { - Gewoon goed werk (o.a. beperken } \\
\text { onzeker werk, aanpakken } \\
\text { werkdruk) } \\
\text { - Gelijk loon voor gelijk werk (o.a. } \\
\text { afschaffen jeugdlonen en laagste } \\
\text { loonschalen omhoog) } \\
\text { - Zeggenschap voor medewerkers } \\
\text { over arbeidstijden, combineren } \\
\text { arbeid en zorg, mantelzorg } \\
\text { - Naleven cao }\end{array}$ \\
\hline $\begin{array}{l}\text { Geen (directe) } \\
\text { speerpunten FNV }\end{array}$ & $\begin{array}{l}\text { - Meer flexibiliteit voor } \\
\text { werkgevers } \\
\text { - Ombouw } \\
\text { ontziemaatregelen } \\
\text { - Demotie } \\
\text { - Creatief loonbeleid } \\
\text { - Toekomstbestendig maken } \\
\text { cao en betrokkenheid } \\
\text { medewerkers bij cao } \\
\text { vergroten }\end{array}$ & \\
\hline
\end{tabular}

Bron: De Bruin en Harteveld, 2015

van de achterban en pas een jaar later kwam er een tripartiet pensioenakkoord (Van den Braak, 2014).

Bij het afsluiten van het sociaal akkoord van 2013 waren een minimaal aantal vertegenwoordigers betrokken, die zich nauwelijks consultatie gunden van de respectievelijke achterbannen. Over de uitvoering van het akkoord is dan ook grote onvrede ontstaan. Natuurlijk, de omstandigheden waren in 2013 uiterst complex en delicaat. Maar juist dat vereiste afstemming met de gang van zaken in individuele ondernemingen, waar evenzeer sprake is geweest van toenemende complexiteit. Voortdurende veranderingen in marktomstandigheden kunnen ondernemingen alleen succesvol tegemoet treden op basis van een dialoog tussen leiding en - vertegenwoordigers van - medewerkers. Organisaties zijn geen gesloten entiteiten meer, maar open werkgemeenschappen met een pluriformiteit aan contractvormen voor de inzet van arbeid, en aan samenwerkingsverbanden. Deze grotere pluriformiteit in arbeidsverhoudingen op ondernemingsniveau maakt een 
gedegen externe en interne voorbereiding nodig om een beleidsthema van macroniveau door te vertalen naar een cao-afspraak.

Ondanks de toenemende relationele afstand tussen het centrale niveau en het cao-niveau heeft het aan de continuïteit van de doorwerking naar inhoudelijke thema's niet geschort. Zo hebben werkgevers en vakbonden vanuit ieders visie hun inzet gepleegd op sociaaleconomisch relevante thema's. Tabel 9.4 illustreert de inzet op zulke thema's en de onderlinge verschillen van werkgevers (AWVN) en vakbonden (FNV) voor het caoseizoen 2014.

Het is al met al lastiger geworden om een centrale aanbeveling om te zetten in een afspraak waar decentrale partijen mee uit de voeten kunnen. De wederkerigheid tussen het macroniveau en cao-partijen staat echt onder druk en de (psychologische) afstand tussen het centrale niveau en het cao-niveau is groter geworden.

\section{Vakbondsagenda blijft gebaseerd op inzet en macht}

De cao is voor de vakbonden ook in deze periode steeds een belangrijk instrument geweest in het arbeidsvoorwaardenbeleid. De FNV - en zij niet alleen - heeft zich telkens weer hard gemaakt voor de zwakkeren op de arbeidsmarkt, met thema's als werkdruk, zorg, werkzekerheid, ouderenbeleid en 'gewoon goed werk' (de decent work-agenda). Het cao-beleid kent net als bij werkgevers een cyclus. In vier fases wordt de cao-agenda vastgesteld: visie op het algemeen arbeidsvoorwaardenbeleid, overleg met (kader)leden, onderhandelingen en uitvoering. Met name de naleving van de cao is een terugkerend onderwerp. De jaarlijkse arbeidsvoorwaardennota van de FNV vakcentrale werd vanaf 2008 een meerjarennota, waarmee het gemakkelijker werd om een thema voor een langere periode te agenderen (FNV vakcentrale, 2000-2014). De vakbeweging is in deze periode in een overlevingsstrijd verwikkeld. Het ledental en de representativiteit in bedrijven vereisen bij voortduring aandacht. In steeds meer ondernemingen speelde de vraag op van de niet-vakbondsleden in welke mate hun stem wordt gehoord. De mede door het dalende ledental ontstane interne strubbelingen, bij de FNV en vele andere vakbonden, geven aanleiding tot fusiebewegingen en heroriëntatie. Het geeft ook aanleiding tot nieuwe initiatieven, zoals CNV Vakmensen en CNV Dienstenbond die per 1 januari 2016 verder onder de naam CNV Vakmensen, en zoals het Alternatief voor Vakbond (AVV) of bedrijfsinterne vakbewegingen. Wat betreft de looncoördinatie heeft de FNV haar machtige instrument van de maximumlooneis, net als voor 2000, stelselmatig ingezet. De relatief zwakke positie van vakbonden op 
macroniveau en de economische tegenwind van rond 2003 respectievelijk vanaf 2008 hebben echter in de praktijk maar een beperkte ruimte geboden om in deze periode in brede zin een vuist te maken.

Behalve op de maximumlooneis, richtte de FNV zich sinds 2010 op organizing, een fenomeen overgewaaid uit de Angelsaksische wereld. Vanuit haar natuurlijke rol was organizing voor de FNV een instrument om de decent work-agenda aan de orde te stellen en tevens om het aantal leden van de vakbond te vergroten. Organizing richt zich op bedrijven waar grove misstanden in het werk worden gesignaleerd. Bij een organizing-activiteit stimuleert de FNV de medewerkers bij het bedrijf in kwestie om hun inbreng te geven. Dat kan overigens voor het betrokken bedrijf zeker niet alleen gedoe opleveren, maar ook tot betere prestaties op langere termijn leiden. Organizing leverde succes op in de schoonmaak, waar schoonmakers hun werk niet meer op een kwalitatief verantwoorde wijze en tegen een fatsoenlijk loon konden uitvoeren. Hier was voor de vakbond een ondergrens in de marktwerking bereikt. Enkele cliënt-bedrijven waar dit speelde - NS en Schipholgroep - werkten uit welbegrepen eigenbelang met de vakbonden een oplossing uit, die medio 2011 werd gepresenteerd als de 'Code verantwoordelijk marktgedrag schoonmaak- en glazenwassersbranche’. Deze code wordt inmiddels uitgebreid naar andere sectoren, zoals de catering en de beveiliging. Het lastige van organizing is dat het bij voorbaat de dialoog met de werkgever belemmert. In plaats van onderhandelen op basis van belangen, loopt de FNV - of een vakbond die een vergelijkbare weg inslaat - het risico van een groeiende oriëntatie op de eigen positie, op unitarisme (Cradden, 2011). In 2015 is bijvoorbeeld een aantal cao's zonder de FNV afgesloten.

\section{Ondernemingen genoodzaakt om cao te vernieuwen}

De centrale inzet van werkgevers laat zich volgen aan de hand van met name de serie arbeidsvoorwaardennota's die VNO-NCW jaarlijks uitbrengt, sinds vrijwel het begin van deze periode in nauwe samenwerking met AWVN en sinds 2007 ook met MKB-Nederland (VNO-NCW, 2000-2014). Als onderdeel van de jaarlijkse cyclus in arbeidsvoorwaardenvorming rapporteerde AWVN (1996-2014) voorts over de gedane gang van zaken in het cao-overleg. In deze periode gingen werkgevers gaandeweg meer accent leggen op de noodzaak tot meerwaarde - het verschil tussen opbrengsten en (loon)kosten - in plaats van het uitsluitend agenderen van het matigen van loonkosten in absolute zin. De inzet van werkgevers kenmerkte zich verder van jaar tot jaar door een brede agenda, waarbij de arbeidsvoorwaarden in tijd, geld 
of flexibilisering steeds werden vergezeld van thema's zoals inzetbaarheid, gezondheid of arbeidsmarkt. De inzet van werkgevers reflecteerde de internationale economische dynamiek die deze periode zo kenmerkt. De internationale samenwerking tussen ondernemingen bij het ontwikkelen van producten en diensten (open innovatie) heeft in deze periode de economische ontwikkeling verder aangewakkerd. Het gaf een impuls aan de verdere globalisering van het ondernemen, mede gefaciliteerd door de snel groeiende technische mogelijkheden van informatieverwerking. Het ontstaan van wereldwijde innovatie- en productieketens intensiveerde de Angelsaksische invloed en de focus op de korte termijn. Het aantal 'moederdochterrelaties' tussen vestiging en hoofdkantoor (in het buitenland dan wel in Nederland) nam toe. De schattingen van het aantal hedendaagse multinationale ondernemingen in Nederland variëren van 60 procent van het aantal bedrijven met een ondernemingsraad in de marktsector (Van der Heijden et. al., 2012, p. 30) tot hoger. Het brengt met zich mee dat de zeggenschap over medewerkers in toenemende mate in buitenlandse handen komt te liggen (De Bruin en Harteveld, 2015). Het aantal medewerkers in buitenlandse bedrijven is in de periode 2008-2012 toegenomen van 782.000 naar 858.0oo werknemers, een toename van 10 procent, gelijk aan 18 procent van de Nederlandse werkgelegenheid (tabel 9.5).

\section{Tabel 9.5 Buitenlandse zeggenschap over werkgelegenheid in bedrijven in Nederland 2008-2012}

\begin{tabular}{lrrr}
\hline & Bederlandse bedrijven & Buitenlandse bedrijven & $\begin{array}{l}\text { Aandeel buitenlandse } \\
\text { zeggenschap in de } \\
\text { totale werkgelegenheid }\end{array}$ \\
\hline & Aantal medewerkers & Aantal medewerkers & \\
$(\times 1.000)$ & $(\times 1.000)$ & $16 \%$ \\
2008 & 4.182 & 782 & $18 \%$ \\
2012 & 3.817 & 858 & \\
Totaal & $-8 \%$ & $+10 \%$ & \\
\hline
\end{tabular}

Bron: CBS, Statline

De werkgelegenheid in de multinationale ondernemingen zelf is ook aan forse verandering onderhevig. Zo is de werkgelegenheid in de vijf grootste multinationals in Nederland in de periode $1985-2012$ met 74 procent gedaald. ${ }^{5}$

5 Cijfers op basis van een presentatie van prof. dr. E. Stam over Entrepreneurial Ecosystems op 26 februari 2015 . 
Als deze trend voor alle multinationale ondernemingen in Nederland zou gelden, dan is het aantal multinationale ondernemingen toegenomen, terwijl de werkgelegenheid per onderneming afnam. Deze ontwikkeling is relevant voor doorwerking. Bij multinationals vinden de onderhandelingen over de loonontwikkeling namelijk veelal op het hoofdkantoor plaats, met smalle marges voor de onderhandeldelegatie in Nederland (Solomon en Quinney, 2010). Deze bedrijven volgen vooral een wereldwijde benchmark als referentie, en de gang van zaken in de Nederlandse vestiging is onderdeel van de internationale vergelijking. Multinationale ondernemingen hebben vanouds flink bijgedragen aan de voorspoed van de open Nederlandse economie en conformeren zich gewoonlijk aan het juridisch kader. Het probleem zit ' $m$ in de toenemende spanning tussen grenzeloos ondernemen - de globalisering - en de belangen van de Nederlandse samenleving in termen van participatie, saamhorigheid en werkgelegenheid. Mede als gevolg van de vele reorganisaties door de crisis diende zich na 2008 wederom een nieuwe generatie buitenlandse managers in Nederlandse vestigingen van multinationals aan. Deze managers zijn niet allemaal vanzelf bekend met de waarde en voordelen van de traditionele Nederlandse arbeidsverhoudingen. Velen handelen conform de strakke spelregels van een (internationaal) concern. Het begrip doorwerking behoort niet per se tot hun woordenschat. Zij spreken in de ogen van institutionalisten een verarmde taal: 'Dit is de deal die onze advocaat voorstelt', of: 'We moeten reorganiseren'. Begrippen als collectief en uniform stammen in buitenlandse ogen uit de vorige eeuw, en zij ervaren de cao als log, star en niet meer van deze tijd. Daarnaast hebben veel ondernemingen in deze periode voor hun human resourcesfunctie een shared service centre ingericht (Meijerink, 2013). Het leidt tot uniformering van procedures, het hanteren van de harde HR-instrumenten en het minimaliseren van het vermogen tot sweet talk voor het beïnvloeden van lokale arbeidsverhoudingen tussen lijnmanager, medewerkers, ondernemingsraad of vakbonden. Het zijn signalen dat ondernemingen die sterker deel uit (zijn gaan) maken van de globalisering, inleveren op hun vermogen of bereidheid om het bedrijfsbelang te verbinden met een maatschappelijk belang in Nederland (Porter en Kramer, 2011). Het effect is dat met name multinationale ondernemingen andere eisen gaan stellen aan de cao en tot vernieuwing willen overgaan. Andere ondernemingen kunnen daar niet lang in achterblijven. Daarnaast hebben bedrijven die recent op eigen kracht zijn gegroeid behoefte om hun arbeidsvoorwaarden op een eigentijdse wijze vorm te geven. Twee opmerkingen zijn hierbij nog relevant. De eerste is dat (multinationale) ondernemingen die mede als gevolg van de crisis fors aan werkgelegenheid hebben ingeleverd het risico van free rider-gedrag met zich 
meebrengen: een grote onderneming is immers gemakkelijker aan te spreken op de maatschappelijke license to operate, waar een kleinere onderneming zich gemakkelijker kan beroepen op specifieke omstandigheden waardoor het (op dat moment) niet mogelijk is om sociaaleconomische belangen te dienen. De tweede opmerking betreft de opkomst van de flexarbeid en de zelfstandige zonder personeel (zzp)(SER, 2010). Naarmate meer personen in deze groepen onder het cao-loon gaan werken, zet dat druk op de brede cao in alle ondernemingen. In de praktijk bleek de cao tot op heden een groot aanpassingsvermogen te kennen, maar dat moeten cao-partijen over en weer wel willen zien. Hier doet de eerdergenoemde oproep van de minister van Sociale Zaken en Werkgelegenheid aan cao-partijen ter zake, om verder te kijken dan alleen het eigen belang. Dat werkgevers - en vakbonden - zich terdege bewust zijn van hun verantwoordelijkheid blijkt onder ander uit het manifest 'Naar nieuwe arbeidsverhoudingen' (AWVN, FNV-Bondgenoten, CNVVakmensen, De Unie, 2011). Het manifest is qua impact verloren gegaan in het sociaaleconomisch tumult en de interne strubbelingen bij vakbonden van de afgelopen jaren, maar de inhoudelijke zeggingskracht is er niet minder om geworden. Indicatief hiervoor is ook dat werkgevers voor het belang van de vakbond een 7,0 als gemiddeld rapportcijfer geven en een 8,0 voor het belang van de cao (De Bruin en Harteveld, 2015).

Het bovenstaande beeld illustreert hoe (multinationale) ondernemingen moeite hebben gekregen om hun korte termijn winststreven te verbinden met sociaaleconomische ambities op langere termijn. Dat legt een hypotheek op het proces van doorwerking en daarmee op de cao als sociaaleconomisch instrument.

\section{Resultaten: gematigde loonontwikkeling en matig sociaaleconomisch succes}

De doorwerking in de periode vanaf 2000 is wederom geëvalueerd op basis van de beschreven activiteiten van partijen in het proces van doorwerking, de loonontwikkeling (output) en de resultaten voor de samenleving (outcome).

De verkleinende centrale beleidsruimte heeft kabinet en sociale partners niet verhinderd om in de periode na 2000 vier tripartiete akkoorden af te sluiten waarin sprake is van de intentie tot het beheersen van de lonen (tabel 9.3: 2002, 2003, 2008 en 2009). Het verzwakkend sociaaleconomisch krachtenveld op centraal niveau kan juist ook aan het afsluiten van de akkoorden hebben bijgedragen, omdat men elkaar nodig had (de Volkskrant, 2015). Hoe dan ook was er sociaaleconomisch gezien telkens aanleiding 
om een akkoord af te sluiten. Het akkoord van 2003 had weliswaar een nadrukkelijk statelijk karakter, terwijl in 2009 er nauwelijks nog sprake was van centrale looncoördinatie. Daarnaast hebben sociale partners binnen de Stichting van de Arbeid een serie bipartiete akkoorden afgesloten, waarbij er twee op looncoördinatie zijn te betrekken (tabel 9.3: 2001 en 2010). Na 2010 is er geen expliciete aanwijzing meer voor centrale looncoördinatie. Waar de relationele afstemming tussen centrale partijen en het cao-niveau onder spanning is komen te staan, heeft het proces van doorwerking er naar de inhoud niet onder te lijden gehad. De inzet van werkgevers respectievelijk vakbonden op cao-niveau was gericht op het vertalen van sociaaleconomische thema's naar de cao-agenda. Ook zijn cao's qua sociaaleconomische onderwerpen zeker niet smaller geworden (AWVN, 1996-2014).

Voor een duiding van de resultaten van doorwerking in loonontwikkeling is weer uitgegaan van de looneis van de FNV. Ook in deze periode heeft de FNV jaarlijks ingezet op een maximumlooneis (zie hiervoor). In figuur $9 \cdot 3$ is de looneis van de FNV afgezet tegen de ontwikkeling van de cao-lonen en de inflatie (afgeleid). Over het algemeen zullen de cao-lonen zich jaarlijks bewegen tussen de inflatie en de maximumlooneis van de vakbonden. De maximumlooneis werd - waar en wanneer dat verantwoord is - overigens geregeld binnengehaald. Het jaar 2001 was gemakkelijk onderhandelen voor de vakbonden; het cao-loon steeg boven de looneis van de FNV uit. De korte en krachtige evaluatie van 2001 van de FNV heette dan ook 'Vragen is krijgen'; werkgevers schreven: 'Het cao-seizoen 2001 blijft in herinnering als het jaar van de vier procent... Dat de uitkomst hoger ligt dan de vraag, is een unicum' (AWVN, 1996-2014). In 2006 deed zich weer zo'n situatie voor. Er waren in totaal drie periodes waarin de FNV een loonruimte boven de inflatie ziet: 2001-2004, 2007-2009 en vanaf 2012. Het is vanaf 2012 niet eenduidig hoe de relatief hoge maximumlooneis van de FNV is te interpreteren: heeft de vakbond overvraagd, was het een politiek signaal naar de eigen achterban of naar de samenleving? Of had het te maken met de toenemende sectorale differentiatie in loonvorming (zie hierna)?

Gedurende deze periode was de effectiviteit van de looncoördinatie wisselend. Terwijl de economische groei tussen 2000 en 2002 achteruit holde, werd de bocht van de matigende looneis en navenante daling van het cao-loon ruim genomen. In de eerste helft van 2009 was de reactiesnelheid op de economische terugval aanzienlijk korter. Al met al was er ook in deze periode sprake van een gematigde loonontwikkeling, tevens in termen van reëel loon (De Beer, 2013).

Hoewel - zeker sinds de crisis van 2008 - regelmatig werd gerapporteerd over een 'poenjaar', heeft de breedheid van de cao er qua onderwerpen 
Figuur 9.3 Ontwikkeling in cao-lonen, inflatie afgeleid en maximumlooneis FNV in de periode 2000-2015

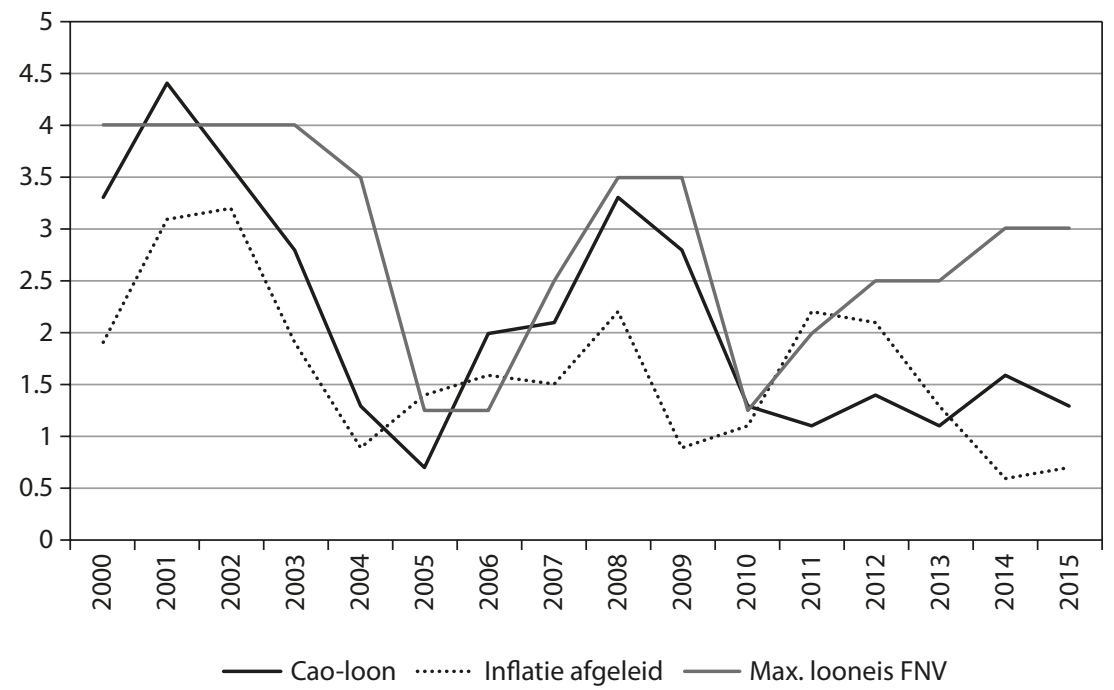

niet onder geleden. Integendeel, veel signalen duiden op een relatief lager belang van het loon in het totale arbeidsvoorwaardenpakket. Het gaat bij dit laatste onder andere om de toename aan keuzemogelijkheden (zoals in een persoonlijk ontwikkelingsplan), mogelijkheden tot scholing of een budget voor inzetbaarheid. Anno 2015 bevatten bijvoorbeeld bijna acht op de tien van de cao-akkoorden ten minste één afspraak over duurzame inzetbaarheid. Van belang is dat de verantwoordelijkheid voor onderwerpen als scholing of inzetbaarheid nadrukkelijk bij de medewerker zelf is komen te liggen, die daardoor zelf keuzes kan maken. Waar vóór de crisis van 2008 nog maar incidenteel sprake was van differentiatie in loonvorming naar sectoren, worden vanaf 2010 gaandeweg verschillende groeipaden zichtbaar. Met name laat de variatie tussen cao's na 2000 een stijgende trend zien. In welke mate deze variatie wordt veroorzaakt door verschillen binnen sectoren dan wel tussen sectoren, vergt nader onderzoek. Nog onhelder is of dit een structurele ontwikkeling is. Het kan betekenen dat de maximumlooneis van de FNV zijn vruchten afwerpt door bij cao's of in een sector waar het beter gaat een hoger structureel loon uit te onderhandelen, dan wel dat er sprake is van invloed van marktwerking.

Als het gaat om resultaten voor ondernemingen en samenleving is het aantal stakingen een relevante indicator (tabel 9.6). Doorwerking betreft immers niet alleen de economische ontwikkeling, maar ook de sociale 
redelijkheid en rust. Tabel 9.6 maakt duidelijk dat de relatieve arbeidsrust in Nederland groot was. Werkstakingen kunnen gerelateerd zijn aan de cao, dan wel spontaan opkomen. Zo ging het bijvoorbeeld volgens het CBS in 2013 bij 11 van de 24 stakingen om de (nieuwe) cao.

Tabel 9.6 Aantal werkstakingen 1999-2013

\begin{tabular}{|c|c|c|c|c|c|c|c|c|c|c|c|c|c|c|c|}
\hline & ஃे & ¿ & $\overline{\text { ¿ }}$ & ๖ั & 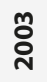 & ষ্ণ & ๕ั & : & ¿্ঠ & : & ঃ & 음 & $\overline{\text { స్ }}$ & ָั & $\sum_{i}^{m}$ \\
\hline Totaal & 24 & 23 & 16 & 16 & 14 & 12 & 28 & 31 & 20 & 21 & 25 & 21 & 17 & 18 & 24 \\
\hline
\end{tabular}

Bron: CBS, Statline

In sociaaleconomisch opzicht kenmerkte de periode na 2000 zich voorts door een gemiddeld bescheiden economische groei en - na 2008 - achterblijvende werkgelegenheid. Hoewel er met de gematigde loonontwikkeling gesproken kan worden van een goed resultaat (output) van doorwerking, leveren de inspanningen voor de samenleving een bescheiden uitkomst (outcome) op.

\section{Conclusies}

In dit hoofdstuk stond de vraag centraal of coördinatie van arbeidsvoorwaardenvorming via doorwerking onder veranderende omstandigheden is blijven functioneren. Daartoe zijn vier voorwaarden voor doorwerking van centrale akkoorden naar het cao-niveau beschreven. Zeker is dat partijen op centraal niveau en cao-niveau hun verantwoordelijkheid hebben genomen bij de reeks van ingrijpende sociaaleconomische gebeurtenissen. De gang van zaken rond de economische neergang in 2003/2004, de financiële crisis van 2008 , het pensioenakkoord en het sociaal akkoord van 2013 illustreren dat. De voornoemde brief van de minister van Sociale Zaken en Werkgelegenheid van november 2015 bevestigt dat beeld op hoofdlijnen. Het stelsel van doorwerking als zodanig staat niet ter discussie. Bovendien is (loon)coördinatie via doorwerking maar een van de mechanismen van het Nederlandse poldermodel. Dat gezegd zijnde, geven de vier voorwaarden voor doorwerking juist wel aanleiding tot discussie.

De afnemende centrale beleidsruimte is van invloed op het coördinatievermogen. Een kabinet kan niet meer geruisloos besturen. De vakbonden staan voor een ingewikkeld vraagstuk qua positionering, terwijl werkgevers 
niet meer vanzelf aansluiten bij de belangen van de BV Nederland. De legitimiteit op centraal niveau is een aandachtspunt geworden (Schmidt, 2013; Wilburn en Wilburn, 2011). Desondanks - of juist daardoor - heeft na 2000 de reeks tripartiete en bipartiete akkoorden steeds minder centrale sturing gegeven aan de ontwikkeling van de arbeidsvoorwaardenvorming. Aanvankelijk heeft het kabinet in 2003/2004 de loonvorming naar zich toe getrokken, terwijl na de crisis van 2008 juist veel ruimte werd gelaten aan decentrale cao-partijen. Die hebben hun verantwoordelijkheid genomen, en de cao is qua positie en sociaaleconomische breedte solide. Deze vooral decentrale looncoördinatie strookt overigens met de voornoemde duiding van Visser dat zulke coördinatie onder meer dient om lonen aan te passen in tijden van crisis. Wellicht betekent deze ontwikkeling op termijn het einde van de centrale looncoördinatie. De afstemming tussen centraal niveau en cao-niveau vertoont in ieder geval tekenen van een moeizamer verlopend relationeel proces, zowel bij vakbonden als bij werkgevers. De vakbondsbereidheid voor doorwerking kan niet los worden gezien van hun interne heroriëntatie en het dalende ledental. De werkgeversbereidheid is weliswaar formeel uitstekend op orde, maar kent spanningen. Deels worden die veroorzaakt door de opkomst van onderhandelingen binnen het specifieke kader van het hoofdkantoor van (multinationale) concerns, die druk zet op de beleidsruimte voor een brede cao-agenda. Onderhandelingen binnen het specifieke kader van een hoofdkantoor hebben hetzelfde effect als marktwerking, omdat het de beleidsruimte voor doorwerking beperkt. De cao staat bovendien onder invloed van grotere marktwerking, die zich aandient via flexibele contractvormen en opdrachten tot het verlenen van diensten door zzp'ers. Marktwerking die echter ook een schaduwkant kent. Verharding in opstelling vormt een risico. Niettemin ziet het merendeel van de ondernemingen de cao nog steeds als een belangrijk instrument. Zij zijn op grond van marktomstandigheden wel genoodzaakt opzet en inhoud van de cao te vernieuwen. Hoewel de formele spelregels hetzelfde blijven, is al met al het onderhandelingsveld rondom de loonvorming echt veranderd. In deze complexe omstandigheden vinden werkgevers en vakbonden elkaar kennelijk niet altijd gemakkelijk in een gezamenlijke probleemanalyse. Is het einde van het proces van doorwerking vanuit een top-downbenadering dan toch in zicht? Het manifest 'Naar nieuwe arbeidsverhoudingen' respectievelijk de 'Code verantwoordelijk marktgedrag schoonmaak- en glazenwassersbranche' uit 2011 illustreren in ieder geval het vermogen van cao-partners om via decentrale initiatieven - vanuit een bottom-up-perspectief - een vernieuwende betekenis te geven aan het concept van doorwerking. 
De resultaten van de doorwerking naar het cao-niveau zijn weliswaar goed en er is sprake van loonmatiging, maar het proces staat uiteindelijk ten dienste van de economische voorspoed en maatschappelijke redelijkheid. De arbeidsrust is in de periode na 2000 zeker bewaard gebleven, maar de sociaaleconomische resultaten in termen van economische groei en werkgelegenheid blijven achter. Heeft dit te maken met de klassieke tijdelijke vertraging die zich na elke zware crisis voordoet? Of is het een voorbode van een baanloze groei, waar velen dezer dagen voor waarschuwen? In dit laatste geval zou de legitimiteit van het stelsel van doorwerking als zodanig ter discussie komen te staan. Los van zulke vrije speculaties is er een risico dat dichter tegen de onderhavige vraagstelling over loonvorming aan ligt. Onze samenleving staat voor de opgave om uiteenlopende sociaaleconomische vraagstukken in goede banen te leiden. Centrale afspraken over loonvorming hebben vanouds altijd een katalyserende werking gehad om ook meer kwalitatieve thema's zoals inzetbaarheid op de cao-agenda te krijgen. Indien decentrale partijen de cao-agenda zelf zetten, is het lastiger om de noodzaak te doorgronden van afspraak over een thema dat verdervan de onderneming af staat. Sociaaleconomische doelen van de samenleving als geheel komen dan onder druk te staan.

Welke interpretatie voor de toekomst van doorwerking ook wordt gevolgd, duidelijk is dat er serieuze risico's zijn. Het grootste risico is wellicht dat partijen er weliswaar bewust van zijn dat er iets moet veranderen, maar niet komen tot een gedeelde probleemanalyse of tot een gedragen oplossing. 



\section{Auteurs}

Paul de Beer: bijzonder hoogleraar op de Henri Polak leerstoel voor Arbeidsverhoudingen, en co-directeur Amsterdams Instituut voor ArbeidsStudies, Universiteit van Amsterdam

Klara Boonstra: hoogleraar Internationaal Sociaal Recht, Vrije Universiteit Amsterdam, en beleidsjurist Federatie Nederlandse Vakbeweging

Caelesta Braun: universitair hoofddocent, Universiteit Leiden

Ewald Engelen: hoogleraar Financiële Geografıe, Universiteit van Amsterdam

Anton Hemerijck: hoogleraar Institutionele Beleidsanalyse, Vrije Universiteit Amsterdam

Maarten Keune: hoogleraar Sociale Zekerheid en Arbeidsverhoudingen, en co-directeur Amsterdams Instituut voor ArbeidsStudies, Universiteit van Amsterdam

Marc van der Meer: bijzonder hoogleraar Onderwijsarbeidsmarkt, Tilburg University en onafhankelijk wetenschappelijk adviseur bij de Samenwerkingsorganisatie Beroepsonderwijs-Bedrijfsleven

Arjen Verhoeff: senior beleidsadviseur en coördinator onderzoek, werkgeversvereniging AWVN

Jelle Visser: emeritus hoogleraar Sociologie, Universiteit van Amsterdam

Natascha van der Zwan: universitair docent, Universiteit van Leiden 



\section{Bibliografie}

Aalbers, Manuel en Ewald Engelen. 2015. The Political Economy of the Rise, Fall and Rise again of Securitization. Guest Editorial Environment and Planning 47: 1597-1605.

Aalbers, Manuel, Ewald Engelen en Anna Glasmacher. 2011. 'Cognitive closure' in the Netherlands: mortgage securitization in a hybrid European political economy. Environment and Planning 43: 1779-1795.

Addison, John, Teixeira Paulino, Katalin Evers en Lutz Bellmann. 2014. 'Indicative and Updated Estimates of the Collective Bargaining Premium in Germany.' Industrial Relations 53 (1): 125-156.

AFM 2010. GeefNederlanders pensioeninzicht. Autoriteit Financiële Markten Geraadpleegd op 9 februari 2015 via http://www.afm.nl/nl/nieuws/2010/jan/rapportpensioeninzicht.aspx.

AFM 2015. Naar een toekomstbestendig tweede pijler-pensioen, Amsterdam: AFM.

Afonso, Alexandre en Jelle Visser. 2014. The Liberal Road to High Employment and Low Inequality. The Dutch and Swiss Social Models in the Crisis. In: European Social Models from Crisis to Crisis, red. Jon Erik Dølvik en Anrew Martin. Oxford: Oxford University Press.

Algemeen Dagblad 2011, 12 oktober. Jongere dankt luxe klimaat aan ons [ingezonden brief].

Allern, Elin en Tim Bale. 2012. 'Political Parties and interest groups: disentangling complex relationships'. Party Politics 18 (1): 7-25.

Anderson, Karin en Anke Hassel. 2013. Pathways of Change in Coordinated Market Economies: Training Regimes in Germany and the Netherlands. In: The Political Economy of the Service Transition. Red. Anne Wren. Oxford: Oxford University Press.

Andeweg, Rudy. 2000. 'Consociational Democracy'. Annual Review of Political Science 3: 509-536. Apeldoorn, Bastiaan, van. 2011. 'De macht van het kapitaal', $S \& D 7$ (8): 165-175.

AWVN 1996-2014. Serie jaarlijkse publicaties CAO-overleg. Den Haag: AWVN.

AWVN 2004. Het werk de maat genomen. Haarlem: AWVN.

AWVN 2014. De toekomst van werk. Den Haag: AWVN.

AWVN 2015. Winst! Ondernemen tussen markt en mensen. Den Haag.

AWVN, FNV-Bondgenoten, CNV Vakmensen, De Unie 2011. Manifest 'Naar nieuwe arbeidsverhoudingen'.

Axelrod, Robert. 1984. The evolution of cooperation. New York.

Baars, Laura van. 2012. Fondsen moeten greep in kas uitleggen. Trouw, 12 december 2012.

Barber, Benjamin. 2003. Strong Democracy. Participatory Politics for a New Age. Berkley: University of California Press.

Becker, Uwe. 2001a. 'Miracle' by Consensus? Consensualism and Dominance in Dutch Employment Development. Economic and Industrial Democracy 22 (4): 453-483.

Becker, Uwe. 2001b. A 'Dutch Model': Employment Growth by Corporatist Consensus and Wage Restraint? A Critical Account of an Idyllic View. New Political Economy 6 (1): 19-43.

Becker, Uwe en Corine Hendriks. 2008. 'As the Central Planningbureau says: The Dutch wage restraint paradigm, its epistemic community and its relevance for comparative research.' International Review of Political Economy 15 (5): 826-850.

Beer, Paul de. 200o. Polderwaan: over spraakmakende economen en sprakeloze sociologen. In: De waan van de dag. Sociale wetenschap en de publieke zaak, red. Peter Ester, Douwe van Houten en Bram Steijn. Amsterdam: Nederlandse Vereniging voor Maatschappij en Cultuurwetenschappen/SISWO. 
Beer, Paul de. 2012. De arbeidsduurverkorting die niet doorging en andere lessen uit de jaren tachtig. TPEdigitaal $6(3 / 4): 45-62$.

Beer, Paul de. 2013. 30 Jaar na Wassenaar: de Nederlandse arbeidsverhoudingen in perspectief. In: Arbeidsverhoudingen onder druk. Preadviezen van de Koninklijke Vereniging voor de Staathuishoudkunde 2013, red. Paul de Beer. Den Haag: SDU.

Beer, Paul de. 2014. Een verplichte bijdrage voor de cao. In:Draagvlakvan de cao. Ontwerpers in Arbeidsverhoudingen, red. Karin van der Veldt en Monica Wirtz. Den Haag: AWVN.

Bekker, Sonja, Marc van der Meer en Ruud Muffels. 2015. Youth unemployment in the Netherlands. Brighton Business School: Style working paper.

Béland, Daniel. 2006. The Politics of Social Learning: Finance, Institutions and Pension Reform in the United States and Canada. Governance 19 (4): 559-583.

Bexell, Magdalena, Jonas Tallberg en Anders Uhlin. 2010. 'Democracy in global governance: the promises and pitfalls of transnational actors', Global Governance 16: 81-101.

Beyers, Jan, Hans Vollaard en Patrick Dumont. 2015. Introduction: European Integration and Consensus Politics. In:European Integration and Consensus Politics in the Low Countries, red. Hans Vollaard, Jan Beyers en Patrick Dumont. Londen: Routledge.

Bezemer, Dirk en Joan Muysken. 2015. Dutch Financial Fragilities, Verkenning voor de WRR, Working paper 13 .

Blyth, Mark. 2007. Powering, puzzling, or persuading? The mechanisms of building institutional orders. International Studies Quarterly $5^{1}$ (4): 761-777.

Boelaars, Ilja en Maarten Koning. 2011. De polderdictatuur dupeert jongeren. de Volkskrant, 23 september 2011.

Boelaars, Ilja, Bram Dirkx, Rick Jonkers en Nikie van Thiel. 2012. Jongeren betalen voor fraude met pensioen. de Volkskrant, 13 januari 2012.

Boer, Marcel de. 2015. DNB President Klaas Knot ziet ruimte voor loonstijgingen, Het Financieele Dagblad, 17 april 2015.

Bos, Dennis, Maurits Ebben en Henk Te Velde, red. 2007. Harmonie in Holland: het poldermodel van 1500 tot $n u$. Amsterdam: Bert Bakker.

Bout, Jan Karel. 1999. Een doorkijkje in de Nederlandse Arbeidsverhoudingen. Haarlem: AWVN.

Bovenberg, Lans. 2014. Pensioeninnovatie in Nederland en de wereld: Nederland kampioen in pensioen? TPE-Digitaal 8 (4): 163-185.

Bovenberg, Lans, Sweder van Wijnbergen, Theo Nijman en Theo Kocken. 2011. Bepaal marktwaarde pensioen. Het Financieele Dagblad 12 oktober 2011.

Braak, Jan Willem van den. 2014. Bijna een eeuw polderwerk ... En daarna. Den Haag: VNO-NCW.

Braun, Caelesta. 2015. 'Gevangen in oude routines? De polder als uitgeholde reflex', Beleid \& Maatschappij, jubileumeditie (verwacht).

Braun, Caelesta en Bert Fraussen. 2015. Dense, Diverse but Unrepresented? Interest group communities in neo-corporatist countries, Comparative interest group populations workshop, Hamburg, 8-10 mei 2015.

Bruin, Geert de en Laurens Harteveld. 2015. Polder onder druk? AWVN Beleidsdocument, nr. 2, maart. https://leden.awvn.nl/beleidsdocumenten.

Buitelaar, Wout en Jan Peter van den Toren. 1999. Tijd in beweging. Haarlem: AWVN.

Carlin, Wendy, Anke Hassel, Andrew Martin en David Soskice. 2014. The Transformation of the German Model. In: European Social Models from Crisis to Crisis, red. Jon Erik Dølvik en Anrew Martin. Oxford: Oxford University Press.

Casey, Bernard. 2012. The implications of the economic crisis for pensions and pension policy in Europe. Global Social Policy 12 (3): 246-265. 
CBS 2012. Sociaaleconomische trends, 1e kwartaal.

CBS 2015. Internationaliseringsmonitor 2015, derde kwartaal. Den Haag.

Commissie Beleggingsbeleid en Risicobeheer 2010. Pensioen: Onzekere zekerheid. Een analyse van het beleggingsbeleid en risicobeheer van de Nederlandse pensioenfondsen. Commissie Beleggingsbeleid en Risicobeheer, 19 januari 2010.

Commissie-Buurmeijer 1993. Enquête naar het functioneren van de organen belast met de uitvoering van de sociale-verzekeringswetten. Tweede Kamer 1992-1993, 22730 nr. 8.

Commissie Toekomstbestendigheid Aanvullende Pensioenen 2010. Een sterke tweede pijler. Naar een toekomstbestendig stelsel van aanvullende pensioenen. Commissie Toekomstbestendigheid Aanvullende Pensioenen, 1 oktober 2010.

Corden Max en Peter Neary. 1982. Booming Sector and De-industrialisation in a Small Open Economy. The Economic Journal 92: 825-848.

CPB 2001. Cijfers betreffende arbeidsinkomensquote en winstquote van de marktsector, CPB notitie, 17 maart 2001, http://www.cpb.nl/en/publication/cijfers-betreffendearbeidsinkomensquote-en-winstquote-van-de-marktsector

CPB 2006. De Nederlandse collectieve uitgaven in historisch perspectief. Centraal Planbureau Nr. 109, februari 2006.

CPB 2012. De huidige en toekomstige groeivan het aandeel zzp'ers in de werkzame beroepsbevolking, Centraal Planbureau Achtergronddocument. http://www.cpb.nl/publicatie/de-huidige-entoekomstige-groei-van-het-aandeel-zzp-ers-in-de-werkzame-beroepsbevolking.

CPB 2013. Kortetermijnraming juni 2013, CPB Policy Brief 2013/o6, http://www.cpb.nl/cijfer/ kortetermijnraming-juni-2013

CPB 2014a. Discussiebijdrage t.b.v. 'IBO Zelfstandigen zonder personeel'. Centraal Planbureau: http://www.cpb.nl/publicatie/discussiebijdrage-tbv-\%E2\%8o\%g8ibo-zelfstandigen-zonderpersoneel\%E2\%8o\%99.

CPB 2014b. Doorsneesystematiek in pensioenen onder druk? CPB Policy Brief 2014/1 Den Haag: Centraal Planbureau.

CPB 2014c. Gescheiden markten? Overheidslonen volgen marktlonen. CPB Policybrief 2014/2, Den Haag: Centraal Planbureau.

CPB 2015. Macro Economische Verkenning 2016. Den Haag: Centraal Planbureau.

CPB 2016. Middellangetermijnverkenning, 2018-2021, CPB Boek 21, http://www.cpb.nl/publicatie/ middellangetermijnverkenning-2018-2021

CPB/DNB/PVK 2003. Financieel Toezicht op Pensioenfondsen. Tussenrapportage van het Centraal Planbureau, De Nederlandsche Bank en de Pensioen \& Verzekeringskamer aan het kabinet inzake de zekerheid van pensioenaanspraken, daarmee samenhangende hersteltermijnen bij ontoereikende solvabiliteit van pensioenfondsen, en de macro-economische gevolgen die hiermee gepaard gaan. Den Haag: CPB/DNB/PVK.

Cradden, Conner. 2011. Unitarism, Pluralism, Radicalism and the Rest. Working Paper 7, Université de Genève.

Crouch, Colin. 1990. The United Kingdom: the rejection of compromise. In: European Industrial Relations: The challenge offlexibility, red. Guido Baglioni en Colin Crouch, Londen: Sage.

Crouch, Colin. 1993. Industrial relations and European state traditions. Oxford: Clarendon.

Crouch, Colin. 2009. 'Privatised Keynesianism: An Unacknowledged Policy Regime.' The British Journal of Politics \& International Relations 11 (3): 382-399.

Crouch, Colin. 2011. The Strange Non-Death of Neoliberalism. Cambridge: Polity Press.

Culpepper, Pepper. 2002. Powering, puzzling, and 'pacting': the informational logic of negotiated reforms. Journal of European Public Policy 9 (5): 774-79o. 
Dam, Peter van, Jouke Turpijn en Bram Mellink, red. 2014. Onbehagen in de polder. Nederland in conflict sinds 1795. Amsterdam: Amsterdam University Press.

D'Art, Daryl en Thomas Turner. 2008. 'Workers and the demand for trade unions in Europe: Still a relevant social force?'. Economic and Industrial Democracy 29 (2): 165-191.

Dekker, Paul en Josje den Ridder. 2014. Burgerperspectieven 2014|3. Den Haag: Sociaal en Cultureel Planbureau.

Dekker, Paul, Pepijn van Houwelingen en Tom van der Meer. 2015. Burgerperspectieven 2015|3. Den Haag: SCP.

Dekker, Ronald en Irma Mooi-Reci. 2011.Tijdelijk werk: vloek of zegen. In: Dynamiek op de Nederlandse arbeidsmarkt, red. Ruben van Gaalen, Jos Sanders, Wendy Smits en Jan Fekke Ybema. Den Haag: CBS-TNO.

De Telegraaf 2011, 15 september. Bondgenoten-baas gaat voor derde versie akkoord.

de Volkskrant 1996, 8 januari. Werkgevers zetten rem op korter werken.

de Volkskrant 2012, 30 juli. Werkgevers willen poldermodel reanimeren.

de Volkskrant 2015, 26 november. Kabinet hecht niet aan eigen beleid.

Dieten, A. 1998. Gidslanden voor pensioenen. Het Financieele Dagblad, 19 september 1998.

DNB 2012. Het Schaduwbankwezen: een verkenning voor Nederland. DNB Occasional Studies $10(5)$.

DNB 2015a. Nederland gebaat bij minder fiscale prikkels tot sparen en lenen, DNB Bulletin, 20 februari 2015 .

DNB 2015b. De vermogensopbouw van huishoudens: is het beleid in balans? Occasional Studies, Vol. 13-1, http://www.dnb.nl/binaries/os13_tcm46-319011.pdf

DNB 2016. Staat van het Toezicht 2015. Amsterdam: DNB.

Dølvik, Jon Erik, Jørgen Goul Andersen en Juhana Vartiainen. 2014. The Nordic Social Models in Turbulent Times: Consolidation and flexible adaptation. In: European Social Models from Crisis to Crisis, red. Jon Erik Dølvik en Anrew Martin. Oxford: Oxford University Press.

Dür, A. 2008. Interest groups in the European Union: How powerful are they? West European Politics 31 (6): 1212-1230.

Dyk, Silke van. 2006. The Poldermodel and its Order of Consensus: A Foucauldian Perspective on Power and Discourse within the Process of Consensus Creation. Acta Politica 41 (4):408-429.

Ebbinghaus, Bernard en Anke Hassel. 2000. Striking deals. Concertation in the reform of continental European welfare states. Journal of European Public Policy 7 (1): 44-62.

Emmerik, Martijn van, Ernest de Vroome en Seth van den Bossche. 2014. Werkgevers Enquête Arbeid 2014. Methodologie en beschrijvende resultaten. Leiden: TNO.

Engelen, Ewald. 2014. De schaduwelite voor en na de crisis: niets geleerd, niets vergeten. Amsterdam: Amsterdam University Press.

Engelen, Ewald. 2015. Don't Mind the Funding Gap: What Dutch post-Crisis Storytelling tells us about Elite Politics in Financialized Capitalism. Environment and Planning 47 (8): 1606-1623.

Engelen, Ewald en Anna Glasmacher. 2015a. The Trojan Horse of the Europe's Capital Markets Union I, https://www.ftm.nl/artikelen/the-trojan-horse-of-europes-capital-markets-union-cmu

Engelen, Ewald en Anna Glasmacher. 2015b. The Trojan Horse of the Europe's Capital Markets Union II, https://www.ftm.nl/artikelen/the-trojan-horse-of-europes-capital-markets-union-part-ii Engelen, Ewald en Martijn Konings. 2010. Financial capitalism resurgent: comparative institutionalism and the challenges of financialization. In: The Oxford handbook of comparative institutional analysis, red. Glenn Morgan, John Campbell, Colin Crouch, Ove Kaj Pedersen en Richard Whitley. Oxford: Oxford University Press. 
Engelen, Ewald, Rodrigo Fernandez en Martijn Konings. 2009. Geographies of financialization in disarray: The Dutch case in comparative perspective. Economic Geography 86 (1): 53-73.

Engelen, Ewald, Ismail Ertürk, Julie Froud, Sukhdev Johal, Adam Leaver, Mick Moran, Adriana Nilsson en Karel Williams. 2011. After the Great Complacence: Financial Crisis and the Politics of Reform. Oxford: Oxford University Press.

Ertürk Ismail en Stefano Solari. 2007. Banks as Continuous Reinvention. New Political Economy 12: 369-88.

Ertürk, Ismail, Julie Froud, Sukhdev Johal, Adam Leaver en Karel Williams. 2007. The democratization of finance? Promises, outcomes and conditions. Review of International Political Economy 14 (4): 553-575.

Europese Commissie. 2013. Innovation Union Scoreboard 2013. Brussel http:/ec.europa.eu/ enterprise/policies/innovation/files/ius-2013_en.pdf.

Eurostat 2014. Taxation Trends in the European Union. http://ec.europa.eu/taxation_customs/ resources/documents/taxation/gen_info/economic_analysis/tax_structures/2014/report.pdf.

Ewijk, Casper van en Martijn van de Ven. 2004. Zekerheid in het geding. Analyse van het financieel toetsingskader voor pensioenfondsen. CPB Document 47. Den Haag: Centraal Planbureau.

Ewijk, Casper van en Coen Teulings. 2011. Nieuw pensioencontract onvermijdelijk. CPB Policy Brief 2011/1. Den Haag: Centraal Planbureau.

Ewijk, Casper van, Nick Draper, Harry ter Rele en Ed Westerhout. 2006. Ageing and the Sustainability of Dutch Public Finances. Den Haag: Centraal Planbureau.

Felbermayr, Gabriel, Daniel Baumgarten en Sybille Lehwald. 2014. Wachsende Lohhungleichkeit in Deutschland. Gütersloh: Bertelsmann Stiftung.

Financieel Stabiliteitscomité 2015, 'Financieel Stabiliteitscomité adviseert verdere afbouw LTVlimiet naar 90\%', http://www.financieelstabiliteitscomite.nl/nl/nieuws/nieuwsbericht/34

FNV vakcentrale 2000-2014. Serie Arbeidsvoorwaardennota's.

Fraussen, Bert. 2014. 'The visible hand of the state: on the organizational development of interest groups', Public Administration 92 (2): 406-421.

Friedman, Milton. 1970. The Social Responsibility of Business is to Increase its Profits. The New York Times Magazine.

FSB 2012. Progress Report on Strengthening the Oversight and Regulation of Shadow Banking. Financial Stability Board, 16 april 2012.

Fuller Gregory. 2015. Who's Borrowing? Credit Encouragement vs. Credit Mitigation in National Financial Systems. Politics \& Society 43 (2): 241-268.

Gelderblom, Oscar. 2015. Cities of Commerce: The Foundations of International Trade in the Low Countries, 1250-1650. Princeton: Princeton University Press.

Gerschenkron Alexander. 1962. Economic Backwardness in Historical Perspective. Harvard: Harvard University Press.

Gestel, Nicolette van, Paul de Beer en Marc van der Meer. 20og. Het hervormingsmoeras van de verzorgingsstaat. Amsterdam: Amsterdam University Press.

Geus, Hans de. 2014. 'Het CPB, machtig instituut met tunnelvisie.' Follow the Money 13-12-2014, http://www.ftm.nl/column/het-cpb-machtig-instituut-met-tunnelvisie-longread/.

Glick, Reuven en Kevin Lansing. 2010. Global Household Leverage, House Prices, and Consumption. Federal Reserve Bank of San Francisco Economic Letter, 11 januari 2010.

Gourevitch, Peter en James Shinn. 2005. Political power and corporate control: The new global politics of corporate governance. Princeton: Princeton University Press.

Graaf, Thom de. 2013. 'Open Affairs', 2e Ben Pauwlezing, oktober 2013, Den Haag. 
Haas, Peter. 1992. 'Introduction: epistemic communities and international policy coordination.' International Organization 46 (1): 1-35.

Habermas, Jurgen. 1996. Contributions to a discourse theory of law and democracy. Cambridge: Polity Press.

Hajer, Maarten. 2006. Doing discourse analysis: coalitions, practices, meaning. In: Words matter in policy and planning. Discourse theory and method in the social sciences, red. Margo van den Brink en Tamara Metze. Utrecht: Koninklijk Nederlands Aardrijkskundig Genootschap.

Hall, Peter en David Soskice. 2001. Varieties of Capitalism. Oxford: Oxford University Press.

Hall, Richard en Alan Deardorff. 2006. 'Lobbying as legislative subsidy'. American Political Science Review 100 (1): 69-84.

Harbridge, Raymond. 1993. Employment Contracts: New Zealand experiences. Wellington Victoria University Press.

Hardie, Iain, David Howarth, Sylvia Maxfield en Amy Verdun. 2013. Banks and the false dichotomy in the comparative political economy of finance. World Politics 65 (4): 691-728.

Hartveld, Leo. 2012. Loonvorming in tijden van crisis, Tijdschrift voor Arbeidsvraagstukken 28 (2): 138-161.

Hassel, Anke. 1999. The Erosion of the German System of Industrial Relations. British Journal of Industrial Relations 37: 484-505.

Häusermann, Silja. 2010. The Politics of Welfare State Reform in Continental Europe:Modernization in Hard Times. Cambridge: Cambridge University Press.

Heemskerk, Eelke. 2007. Decline of the Corporate Community. Network Dynamics of the Dutch Business Elite. Amsterdam: Amsterdam University Press.

Heemskerk, Eelke en Meindert Fennema. 2008. Nieuwe Netwerken: de ondergang van de NV Nederland. Amsterdam: Bert Bakker.

Heijden, Paul van der, Ferdinand Grapperhaus, Guus Heerma van Voss, Levinus Timmerman en Evert Verhulp. 2012. Medezeggenschap: Ontwikkelingen in de 21 eeuw. SER-notitie.

Hemerijck, Anton. 1992. The Historical Contingencies of Dutch Corporatism, Oxford: University of Oxford.

Hemerijck, Anton. 1994. Hardnekkigheid van corporatistisch beleid in Nederland. Beleid en Maatschappij, 21 (1-2): 23-47.

Hemerijck, Anton. 2013. Changing welfare states. Oxford: Oxford University Press.

Hemerijck, Anton en Jelle Visser. 2001. The Dutch Model: an obvious candidate for the Third Way' (with Jelle Visser). Archives Europeénnes de Sociologie / European Journal of Sociology $42(1): 221-242$.

Hendriks, Corina. 2010. The story behind the Dutch model. Consensual politics of wage restraint. Proefschrift. Oisterwijk: BOXPress.

Herkströter, C.A.J. en F.J. de Graaf. 2002. Verantwoord Ondernemen en Rapportage. Economisch Statistische Berichten, 12 juli, 528-529.

Het Financieele Dagblad 1996, 10 september. Nederland, gidsland met een relatief voortreffelijk pensioenstelsel.

Hicks, Alexander en Lane Kenworthy. 1998. Cooperation and Political Economic Performance in Affluent Democratic Capitalism. American Journal of Sociology 103: 1631-1672.

Hinrichs, J. 2011. Directeur Lex Hoogduin: 'Pensioenfondsen kunnen bron van instabiliteit worden'. Het Financieele Dagblad, 15 juni 2011.

Hodgson, Geoffery. 2006. What are institutions? Journal of economic issues 1: 1-25.

Houwing, Hester. 2010. A Dutch approach to Flexicurity? Negotiated change in the organization of temporary work. Proefschrift. Amsterdam: UvA. 
Howell, Chris. 2005. Trade Unions and the State: The construction of industrial relations institutions in Britain, 189o-200o. Princeton, NJ.: Princeton University Press.

IMF 2014. Fiscal Policy and Income Inequality, Washington DC: IMF Policy Paper.

Jaspers, Teun en Marjolein Baltussen, red. 2011. De toekomstvan het cao-recht. Reeks Vereniging voor Arbeidsrecht nr. 39. Deventer: Kluwer.

Jaumotte Florence en Carolina Orsono Buitron. 2015. Inequality and Labour Market Institutions. IMF Staff Discussion Note 15/14. Washington DC.: IMF.

Jongerius, Agnes, Bernard Wientjes en anderen. 2011. Waarheid over ons akkoord. Het Financieele Dagblad, 29 juni, 2011.

Kamerstuk, Tweede Kamer 2008-2009. 30 413, 127, 25 mei 2009 [brief minister Donner over problematiek aanvullende pensioenen].

Kamerstuk, Tweede Kamer 2009-2010. 30 413, 142, 7 april 2010 [brief minister Donner over 'toekomst aanvullend pensioenstelsel: kabinetsinzet'].

Kamerstuk, Tweede Kamer 2010-2011. 30 413, 157, 10 juni 2011 [brief minister Kamp over 'overleg van het kabinet met de Stichting van de Arbeid'].

Kamerstuk, Tweede Kamer 2011-2012. 33 280, 1, 25 mei 2012 ['Voorjaarsnota 2012'].

Kamerstuk, Tweede Kamer 2013-2014. 32 043, 172, 1 oktober 2013 ['Follow up consultatie voorontwerp van wet financieel toetsingskader (ftk)'].

Kamerstuk, Tweede Kamer 2014-2015 32 043, 241, 19 januari 2015 [brief staatssecretaris Klijnsma over 'toekomst pensioenstelsel'].

Kamerstuk, Tweede Kamer 2014-2015. 32 043, 254, 11 maart 2015 [SER-advies 'toekomst pensioenstelsel'].

Katz, Richard en Peter Mair. 2009. 'The Cartel Party Thesis: A Restatement', Perspectives on Politics 7 (4): 753-766.

Katzenstein, Peter. 1985. Small States in World Markets. Industrial policy in Europe. Ithaca, NY: Cornell University Press.

Keesing, Frans. 1978. De conjuncturele ontwikkeling van Nederland en de evolutie van de economische overheidspolitiek 1918-1939. Nijmegen: SUN.

Kenworthy, Lane. 2000. Quantitative Indicators of Corporatism: A Survey and Assessment, MPIfG Working Paper oo/4.

Kenworthy, Lane. 2009. Jobs with Equality. Oxford: Oxford University Press.

Kersbergen, Kees van en Frans van Waarden. 2001. Shifts in Governance: Problems of Legitimacy and Accountability. Den Haag: NOW.

Keune, Maarten. 2012. The social dimension of European integration. In: Economy and Society in Europe: A Relationship in Crisis. Burroni, Luigi, Maarten Keune en Guglielmo Meardi, red. Cheltenham: Edward Elgar Publishing.

Keune, Maarten en Paul Marginson. 2013. Transnational Industrial Relations as Multi-Level Governance: Interdependencies in European Social Dialogue. British Journal of Industrial Relations $5^{1}$ (3): 473-497.

Klüver, Heike en Sabine Saurugger. 2013. Opening the black box: The professionalization of interest groups in the EU. Interest Groups \& Advocacy, 2 (2): 185-205.

Knegt, Robert, Jan Klein Hesselink, Hester Houwing en Peter Brouwers. 2007. Tweede evaluatie Wet flexibiliteit en zekerheid. Amsterdam: Hugo Sinzheimer Instituut en TNO. https:// www.rijksoverheid.nl/documenten/kamerstukken/2007/07/03/rapport-hugo-sinzheimerinstituut-en-tno-tweede-evaluatie-wet-flexibiliteit-en-zekerheid. 
Knot, Klaas. 2013. Speech Klaas Knot - Afscheidssymposium Jan Hommen, http://www.dnb.nl/ binaries/Speech\%2oafscheid\%20Jan\%2oHommen_tcm46-297055.pdf.

Koenen, Bart. 2014. Issuemonitor 2014 Pensioenen. Amsterdam: Veldkamp.

Kok, Lucy, Barbara Baarsma en Arjan Heyma. 2014. Nieuw ontwerp sociaal beleid, Beoordeling van AWVN voorstel voor een basisregeling voor werkenden. Amsterdam: SEO. http://www. seo.nl/uploads/media/2014-48_Nieuw_ontwerp_sociaal_beleid.pdf.

König, Eppo. 2011. De opstand van jong tegen oud (en rijk). NRC Handelsblad, 8 oktober, 2011.

Korte, Harman. 2013. Eerlijker over pensioen. Speech tijdens Eye on Pensions, 14 januari 2013, Wassenaar.

Kremer, Monique, Mark Bovens, Erik Schrijvers en Robert Went, red. 2014. Hoe ongelijk is Nederland? Een verkenning van de ontwikkeling en gevolgen van economische ongelijkheid. WRR Verkenning 28. Den Haag: WRR.

Kuipers, Sanneke. 2005. The Crisis Imperative. Crisis rhetoric and welfare state reforms in Belgium and The Netherlands in the early 199os. Amsterdam: Amsterdam University Press.

Lehmbruch, Gerhard. 1977. Liberal corporatism and party government. Comparable Political Studies 10 (1): 91-125.

Lehmbruch, Gerhard en Philippe Schmitter, red. 1982. Patterns of Corporatist Policy-Making. Beverly Hills: Sage.

Lendering, Jona. 2005. Polderdenken. De wortelsvan de Nederlandse overlegcultuur. Amsterdam: Athenaeum-Polak \& Van Gennep.

Lesger, Clé. 2001. Handel in Amsterdam ten Tijde van de Opstand. Amsterdam: Verloren.

Lijphart, Arend. 1969. 'Consociational Democracy', World Politics 21: 207-225.

Lijphart, Arend. 1999. Patterns of Democracy: government forms and performance in thirty-six countries. New Haven: Yale University Press.

Lijphart, Arend en Markus Crepaz. 1991. Corporatism and Consensus Democracy in Eighteen Countries: Conceptual and Empirical Linkages. British Journal of Political Science, 21 (2): $235-246$.

Loonstra, Cees. 1989. 'Van autonoom tot heteronoom sociaal recht', Beleid \& Maatschappij 16: 145-154.

Lowery, David. 2013. 'Lobbying and Influence: meaning, measurement and missing', Interest Groups and Advocacy 2 (1): 1-26.

Lowery, David, Frank Baumgartner, Joost Berkhout, Jeffrey Berry, Darren Halpin, Marie Hojnacki, Heike Klüver, Beate Kohler-Koch, Jeremy Richardson en Kay Lehman Schlozman. 2015. 'Images of an unbiased interest system', Journal of European Public Policy 22 (8): 1212-1231.

Lowery, D. Gray, V., Kirkland, J., Harden, J.J. 2012. Generalist Interest organizations and interest system density: a test of the competitive exclusion hypothesis. Social Science Quarterly 93 (1): 21-41.

Mair, Peter. 2013. Smaghi versus the Parties: Representative government and Institutional Constraints. In: Politics in the age of Austerity, red. Armin Schäfer en Wolfgang Streeck. UK: Polity press.

Mair, Peter. 2016. Polity-scepticism, party-failings and the challenge to European democracy. Uilenbeek Lecture.

Mair, Peter en Jacques Thomassen. 2010. 'Political Representation and government in the European Union', Journal of European Public Policy 17 (1): 20-35.

Maloney William en Jan van Deth, red. 2012. Civil Society and Activism in Europe. Contextualizing engagement and political orientations. Londen: Routledge. 
Marginson Paul en Christian Welz. 2014. Changes to wage-setting mechanisms in the context of the crisis and the EU's new economic governance regime. Dublin. European Foundation. http://www.eurofound.europa.eu/eiro/studies/tn1402049s.

McCloskey, Deirdre. 2007. The Bourgeois Virtues: Ethics for an Age of Commerce. University of Chicago Press.

Meer, Marc van der en Jelle Visser. 2010. 'Doing together what is possible'. Social pacts and negotiated welfare reform in the Netherlands. In: Pochet, Philipe, Maarten Keune en David Natali, red. After the Euro and Enlargement: Social Pacts in the EU. Brussel: ETUI.

Meijden, A. van der en M. van der Meer. 2013. Vierde Monitor O\&O-fondsen:van pepernoten naar spekkoek, 's-Hertogenbosch: ecbo.

Meijerink, Jeroen. 2013. Beyond Shared Savings: A multilevel analysis of the perceived value ofHR shared services. Proefschrift Universiteit Twente.

Melbourne Mercer Global Pension Index (meerdere jaren); laatst bekeken 12 oktober 2015 via http://www.globalpensionindex.com/.

Mian, Atif en Amir Sufi. 2014. House of Debt. Princeton: Princeton University Press.

Ministerie van Financiën 2013. Miljoenennota 2014.

Ministerie van SZW 2001-2011. Voorjaarsrapportage cao-afspraken 2001-2011. Den Haag: Arbeidsinspectie/Ministerie van SZW.

Ministerie van SZW 2012-2015. Cao-afspraken 2012-2014. Den Haag: Ministerie van SZW.

Ministerie van SZW 2014. Cao-afspraken 2013. Den Haag: Ministerie van SZW.

Ministerie van SZW 2015. Tussenevaluatie CAO-resultaten 2014, Den Haag; Ministerie van SZW.

Mommers, Jelmer, Belia Heilbron, Thomas Muntz en Huib de Zeeuw. 23 oktober 2013. 'Reconstructie: hoe de SER een onmogelijk akkoord sloot. De herontdekking van de polder', De Groene Amsterdammer 137 (43).

Mooij, Martin de, Alderina Dill, Marleen Geerdinck en Esther Vieveen. 2012. Witte Vlek op Pensioengebied 2010. Den Haag: Centraal Bureau voor de Statistiek.

Muffels, Ruud. 2013. 'Flexibilisering en de toegang tot de arbeidsmarkt'. TPEdigitaal. 7 (4): 79-98.

Naurin Daniel. 2010. 'Most common when least important: deliberation in the European council of ministers', British Journal of Political Science 40 (1): 31-50.

Naurin, Daniel. 2007. Deliberation behind closed doors. Transparency and Lobbying in the European Union. Essex: ECPR press.

OECD 2013. Pension Markets in Focus 2013. Parijs: OECD.

OECD 2015a. Pension Markets in Focus 2015. Parijs: OECD.

OECD 2015b. Pensions at a Glance 2015: OECD and G2o Indicators. Parijs: OECD.

Oeij, Peter, Ernest de Vroome, Karolus Kraan, Anneke Goudswaard en Seth van den Bossche. 2013. Werkgevers enquête arbeid 2012. Methodologie en beschrijvende resultaten. Hoofddorp: TNO. OESO 2013. Pensions at a Glance: OECD and G2o indicators. Parijs: OESO.

OESO 2014. Does Income Inequality Hurt Economic Growth? Parijs: Organisatie voor Economische Samenwerking en Ontwikkeling.

Otjes, Simon en Gerrit Voerman. 2014. “Geen degelijk kabinet'?'. In: Halverwege? Tussenbalans kabinet-Rutte II, red. Gerrit Voerman. Montesquieu-reeks, 4: 7-20.

PBS News Hour. 2013. Do the Dutch have the pension problem solved? PBS News Hour 10 november 2013 .

Pechtold, Alexander. 2013. 'Het failliet van de polder 2.o.' $N R C$ 13 september 2013. 
Pensioenfederatie 2010. Beleggen nodig voor goed pensioen. 5 januari 2010 [persbericht]. http:// www.pensioenfederatie.nl/Document/Pers/Archief\%202008-2010/P_Angst\%20voor\%20 beleggen\%2ozit\%2odiep.pdf.

Pierson, Paul. 1993. When Effect Becomes Cause: Policy Feedback and Political Change. World Politics 45 (4): 595-628.

Pierson, Paul. 2001. The New Politics of the Welfare State. Oxford: Oxford University Press.

Pitkin, Hannah. 1967. The concept of representation. Berkeley, Londen: University of California Press.

Pitkin, Hannah. 2004. 'Representation and Democracy: an uneasy alliance', Scandinavian Political Studies 27 (3): 335-342.

PO-Raad 2014. Jaarverslag 2013. Utrecht: PO-Raad.

Porter, Michael en Mark Kramer. 2011. Creating Shared Value. Harvard Business Review.

Prak, Maarten en Jan Luiten van Zanden. 2013. Nederland en het Poldermodel. Amsterdam: Uitgeverij Bert Bakker.

Prast, Henriette en Iman van Lelyveld. 2004. New Architectures in the Regulation and Supervision of Financial Markets and Institutes. DNB Working Paper, 21.

PVK 1990. Financiële gegevens van de bedrijfspensioenfondsen, de ondernemingspensioen- en ondernemingsspaarfondsen en de beroepspensioenfondsen. Pensioen- en Verzekeringskamer, Apeldoorn: Verzekeringskamer.

PVK 1999. Financiële gegevens van de bedrijfspensioenfondsen, de ondernemingspensioen- en ondernemingsspaarfondsen en de beroepspensioenfondsen. Pensioen- en Verzekeringskamer, Apeldoorn: Verzekeringskamer.

PVK 2002. Uitgangspunten voor de financiële opzet en positie van pensioenfondsen. Pensioen- en Verzekeringskamer, 30 september 2002 [brief aan de besturen van pensioenfondsen].

Raad van State 2013, jaarverslag 2013. Den Haag: Raad van State.

Rayer, Cecil. 2014. Wetgeving en beleid voor flexibele arbeid, Monografieën Sociaal Recht, deel 61, Deventer: Kluwer.

Regeringsverklaring Rutte II, 13 November 2012.

Rhodes, Martin. 2001. The Political Economy of Social Pacts: 'Competitive Corporatism' and European Welfare Reform. In: The New Politics of the Welfare State, red. Paul Pierson. Oxford: Oxford University Press.

ROB 2012. Loslaten in vertrouwen. Naar een nieuwe verhouding tussen overheid, marktén samenleving. Den Haag: Raad voor het Openbaar Bestuur.

Rojer, Maurice. 2012. Revitalisering van de overlegeconomie. In: Ontwerpers in arbeidsverhoudingen. Schets, beeld en ambitie, red. Arjen Verhoeff en Geert de Bruin. Den Haag: AWVN.

Rojer, Maurice en Harteveld Laurence. 2002. Doorwerking via actieve looncoördinatie. $B \& M$ Themanummer 190-203.

Rokkan, Stein. 1970. Citizens, Elections, Parties. Oslo: Universitetsforlaget.

Rooy, Piet de. 2014. Ons Stipje op de wereldkaart. De politieke cultuur van modern Nederland. Amsterdam: Wereldbibliotheek.

Ruysseveldt, Joris van en Jelle Visser. 1996. Weak Corporatisms Going Different Ways? Industrial relations in the Netherlands and Belgium. In: Industrial Relations in Europe. Traditions and transitions, red. Joris Van Ruysseveldt en Jelle Visser. Londen: Sage.

Sabel, Charles. 1994. Learning by monitoring: the institutions of economic development. In: The handbook of economic sociology, red. Neil Smelser en Richard Swedberg. Princeton: Princeton University Press. 
Salverda, Wiemer. 1977. Haalt de arbeidsinkomenskwote de 100 procent? En wat dan nog... Tijdschrift voor Politieke Economie, 1 (4): 66-94.

Salverda, Wiemer. 1999. Polderblijheid, polderblindheid. Economische Statistische Berichten, 84 (4196): 224-228.

Salverda, Wiemer. 2015. Merit en werk in 1960-2010. Effecten van de Nederlandse onderwijs- en deeltijdtsunamis. In Een kloof van alle tijden, red. Herman van de Werfhorst. Amsterdam: Amsterdam University Press.

Scharp, Fritz. 2009. 'Legitimacy in the multilevel European polity', European Political Science Review 1: 173-204.

Scharpf, Fritz. 1999. Governing in Europe: Effective and Democratic? Oxford: Oxford University Press.

Schils, Trudie. 2007. Employment protection in Dutch collective labour agreements. AIAS Working Paper 56. Amsterdam: Amsterdam Institute for Advanced Labour Studies.

Schmidt, Vivien. 2013. 'Democracy and Legitimacy in the European Union revisited: input, output and throughput legitimacy'. Political Studies 61: 2-22.

Schmitter, Philippe. 1989. Corporatism is Dead! Long Live Corporatism! Government and Opposition $24(1): 54-73$.

Schmitter, Philippe en Gerard, Lehmbruch. 1979. Trends towards Corporatism Intermediation. Londen: Sage.

SCP 2014. Verenigd in Verandering. Grote maatschappelijke organisaties in de Nederlandse civil society. Den Haag: Sociaal en Cultureel Planbureau.

Schwartz, Herman. 2000. Internationalization and Two Liberal Welfare States: Australia and New Zealand. In: Work and Welfare in the Open Economy, red. F.W. Scharpf en V.A. Smidt, Oxford: Oxford University Press.

SEO 2013. Uit de schaduw van het bankwezen. SEO-rapport, 31.

SER 2010. Zzp'ers in beeld. Een integrale visie op zelfstandigen zonder personeel. Advies 10/04.

SER 2012. Advies Verschuivende economische machtsverhoudingen. Den Haag: Sociaal-Economische Raad.

SER 2013. Advies Verbreding draagvlak cao-afspraken. Den Haag: Sociaal-Economische Raad.

SER 2015a. Werkloosheid voorkomen, beperken en goed verzekeren. Een toekomstbestendige arbeidsmarktinfrastructuur en Werkloosheidswet. Advies 15/02. Den Haag: Sociaal-Economische Raad.

SER 2015b. Uitwerking pilots adviescentra en regie. Brief aan de Minister van SZW Lodewijk Asscher, d.d. 2 juli 2015. Den Haag: Sociaal-Economische Raad.

SFL 2014. Een Schuldbewust Land: Naar een Stabiel en Duurzaam Nederland. SFL rapport, 7.

Smit, Evert. 2013. De syndicale onderstroom. Stakingen in de Rotterdamse haven, 189o-2010. Amsterdam: Vossiuspers.

Solomon, Richard en Nigel Quinney. 2010 American Negotiating Behavior. United States Institute of Peace.

SOMO 2013. Should the Netherlands sign tax treaties with developing countries? Juni 2013.

Spits 2011. Jongeren de pineut. Spits 14 juni 2011.

Staal, Teun. 2011. Kan veertiger straks ook nog golfbaan op, dat is de vraag. Twentse Courant Tubantia, 30 juni 2011.

Stam, Erik. 2014. Ecosysteem voor ambitieus ondernemerschap. Opening Global Entrepreneurship Week 2014.

Steiner, Jorg, Andreas Bächtiger, Markus Spörndli en Marco Steenbergen. 2005. Deliberative Politics in Action: Analyzing Parliamentary Discourse. Cambridge: Cambridge University Press. 
Stichting ZZP Nederland. 2014. Stand van zaken. Zelfstandigen zonder personeel in Nederland. http://www.rtlnieuws.nl/sites/default/files/content/documents/2014/12/23/Stand\%2o van\%20zaken\%20zzp2014.pdf

Streeck, Wolfgang. 1992. Social Institutions and Economic Performance: Studies of Industrial Relations in Advanced Capitalist Economies. Londen: Sage.

Streeck, Wolfgang. 1998. Industrial Relations in an International Economy. In: The Challenge of Globalization for Germany's Social Democracy, red. Dieter Dettke. New York: Berghahn Books.

Streeck, Wolfgang. 2009. Re-Forming Capitalism: Institutional change in the German political economy. Oxford: Oxford University Press.

Streeck, Wolfgang. 2013. Gekaufte Zeit. Suhrkamp Verlag: Frankfurt am Mein.

Streeck, Wolfgang. 2015. Gekochte tijd. Amsterdam: Leesmagazijn.

Streeck, Wolfgang en Colin Crouch, red. 2006. The Diversity of Democracy. Corporatism, Social Order and Political Conflict. Cheltenham: Edgar Elgar.

Streeck, Wolfgang en Philippe Schmitter. 1985. Community, Market, State-and Associations? The Prospective Contribution of Interest Governance to Social Order. European Sociological Review 1 (2): 119-138.

StvdA 1982. Centrale aanbevelingen inzake aspecten van een werkgelegenheidsbeleid. Den Haag: Stichting van de Arbeid.

StvdA 1996. Nota Flexibiliteit en Zekerheid. Stichting van de Arbeid. http://www.stvda.nl/ / media/Files/Stvda/Nota/1990_1999/1996/19960403.ashx.

StvdA 2011. Uitwerkingsmemorandum Pensioenakkoord van 4 juni 2010. Den Haag: Stichting van de Arbeid.

StvdA 2013a. Verklaring van de Stichting van de Arbeid, de Pensioenfederatie, FNV-Jong, CNV Jongeren, CSO (Unie KBO, PCOB, NVOG en Noom), ANBO, KNVG en FNV Senioren over de verdere uitwerking van de spelregels voor nieuwe pensioencontracten. Den Haag: Stichting van de Arbeid, 13 september 2013.

StvdA 2013b. Perspectief voor een sociaal én ondernemend land: uit de crisis, met goed werk, op weg naar 2020. (Sociaal akkoord) Den Haag: Stichting van de Arbeid, 11 april 2013.

Teulings, Coen en Joop Hartog. 1998. Corporatism or competition. Cambridge: Cambridge University Press.

The Guardian. 2014. Government plans Dutch-style collective pension scheme, The Guardian 1 juni 2014 .

Thelen, K. 2004. How Institutions Evolve: The Political Economy of Skills in Germany, Britain, the United States and Japan. New York: Cambridge University Press.

Therborn, Goran. 1986. Why some People are more Unemployed than Others. Londen: Verso.

Tijdelijke Commissie Huizenprijzen 2013. Kosten Koper: Een Reconstructie van Twintig Jaar Stijgende Huizenprijzen. Kamerstuk 33194 (3).

TNO 2015. WEA Trendtabellen 2008-2014. http://www.monitorarbeid.tno.nl/dynamics/modules/ SFILo10o/view.php?fil_Id=142.

Touwen, Jeroen. 2014. Coordination in transition; The Netherlands and the world economy 1950 2010. Leiden: Koninklijke Brill NV.

Traxler, Franz. 2004. The metamorphoses of corporatism: From classical to lean patterns. European Journal of Political Research 43 (4): 571-598.

Traxler, Franz. 2010. The long-term development of organized business and its implications for corporatism: A cross-national comparison of membership, activities and governing capacities of business interest associations, 1980-2003. European Journal of Political Research 49 (2): 151-173. 
Traxler Franz, Sabine Blaschke en Berhard Kittel. 2001. National Labor Relations in Internationalized Markets: A comparative study of institutions, change, and performance. Oxford: Oxford University Press

Traxler, Franz en Bernd Brandl. 2012. Collective Bargaining, Inter-Sectoral Heterogeneity and Competitiveness: A cross-national comparison of macroeconomic performance. British Journal of Industrial Relations 50: 73-98.

Tros, Frank, Wil Albeda en Willem Dercksen. 2006. Arbeidsverhoudingen in Nederland. $7^{\mathrm{de}}$ druk. Deventer: Kluwer.

Turner, Thomas en Daryl D'Art. 2012. 'Public perceptions of trade unions in countries of the European Union: A causal analysis.' Labor Studies Journal. 37 (1): 33-55.

Velden, Sjaak van der. 2004. Werknemers in actie. Twee eeuwen stakingen, bedrijfsbezettingen en andere acties in Nederland. Amsterdam: Aksant.

Vergeer, Robert en Alfred Kleinknecht. 2011. The impact of labor market deregulation on productivity: A panel data analysis of 19 OECD countries (1960-2004).Journal of Post-Keynesian Economics 33 (2): 369-404.

Verhoeff, Arjen. 2007. Handboek Levensfasebeleid. Den Haag: AWVN.

Verhoeff, Arjen en Geert de Bruin, red. 2012. Ontwerpers in arbeidsverhoudingen. Schets, beeld en ambitie. Den Haag: AWVN.

Verhoeff, Arjen en Geert De Bruin. 2013. De waarde van het Sociaal Akkoord: In crisistijd herleeft de polder. Zeggenschap, 24 (2): 8-11.

Verhoeff, Arjen en Hans van der Steen. 2015. Winst! Ondernemen tussen markt en mensen. Den Haag: AWVN.

Visser, Jelle. 2007. 'De wankele evenwichten van het corporatisme', Beleid en Maatschappij 34: 6-22.

Visser Jelle. 2013a. Flexibility and Security in Post-Standard Employment Relations: The case of the Netherlands. In: Beyond the Employment Contract, red. Harry Arthurs en Katherine Stone. New York: Russell Sage.

Visser, Jelle. 2013b. Wage Bargaining Institutions - from crisis to crisis. European Commission. Economic papers, 488 .

Visser Jelle. 2015. The Institutional Characteristics of Trade Unions, Wage Setting, State Intervention and Social Pacts. ICTWSS Database, version 5.o. Amsterdam: Amsterdam institute for Advanced Labour Studies, november 2015. http://www.aias-uvanet.nl/

Visser Jelle. 2016. 'What Happened to Collective Bargaining During the Great Recession.' IZA Journal of Labor Policy. Forthcoming.

Visser, Jelle en Anton Hemerijck. 1997. 'A Dutch Miracle'. Job growth, welfare reform and corporatism in the Netherlands. Amsterdam: Amsterdam University Press.

Visser, Jelle en Anton Hemerijck. 1998. Een Nederlands Mirakel. Beleidsleren in de verzorgingsstaat, Amsterdam: Amsterdam University Press.

Visser, Jelle en Marc van der Meer. 2011. The Netherlands: social pacts in a concentration economy. In: Social Pacts in Europe: emergence, evolution, and institutionalization, red. Sabine Agdavic, Martin Rhodes en Jelle Visser. Oxford: Oxford University Press.

Visser, Jelle, Susan Hayter en Rosina Gammarano. 2015. The coverage of collective bargaining: Stability, erosion or decline. Labour Relations and Collective Bargaining Policy Brief No.1. Genève: International Labour Organization.

VNO-NCW 2000-2014. Serie Arbeidsvoorwaardennota's. 
Weaver, Kent. 2015. Policy Feedbacks and Pension Policy Change. In: Challenges of Aging: Pensions, Retirement and Generational Justice, red. Cornelus Torp. Basingstoke: Palgrave.

Werkgroep Europese Pensioenen (2007). Nederland pensioenkampioen: wat staat ons nog te doen? http://www.toezicht.dnb.nl/binaries/50-212257.pdf.

Wester, Joris en Jeroen Wester. 20o9. Hoe Den Haag de banken bediende: onderzoek politiek en kredietcrisis, NRC Handelsblad Magazine, 27-28 juni, 18-22.

Wilburn, Kathleen en Ralph Wilburn. 2011. Achieving social license to operate using stakeholder theory. Journal of International Business Ethics 4 (2): 3-16.

Woldendorp, Jaap. 2013. 'De polder is nog lang niet dood'. Socialisme \& Democratie. 70 (2): 46-51.

Wren, Anne, Mate Fodor en Sotiria Theodoropoulou. 2013. The Trilemma Revisited: Implications for inequality and employment creation of the ICT revolution and the expansion of service trade. In: The Political Economy of the Service Transition, red. Anne Wren. Oxford: Oxford University Press.

WRR 2007. De Verzorgingsstaat herwogen: van verzekeren en verzorgen naarverheffen en verbinden. Wetenschappelijke raad voor het regeringsbeleid. Amsterdam: Amsterdam University Press.

WRR 2012a. Vertrouwen in burgers. Wetenschappelijke raad voor het regeringsbeleid. Amsterdam: Amsterdam University Press.

WRR 2012b. Dertig jaar privatisering. WP65. Den Haag: Wetenschappelijke raad voor het regeringsbeleid.

Zwan, Natascha van der. 2014. Making Sense of Financialization. Socio-Economic Review 12 (1): 99-129.

Zysman, John. 1983. Government, Markets and Growth: Financial Systems and the Politics of Industrial Change. Ithaca: Cornell University Press. 